UNIVERSIDADE DE SÃO PAULO

FACULDADE DE FILOSOFIA, LETRAS E CIÊNCIAS HUMANAS

DEPARTAMENTO DE SOCIOLOGIA

PROGRAMA DE PÓS-GRADUAÇÃO EM SOCIOLOGIA

RAFAELA NUNES PANNAIN

A crise do Estado boliviano e a autonomia indígena

Versão corrigida em outubro de 2014

São Paulo

2014 
UNIVERSIDADE DE SÃO PAULO

FACULDADE DE FILOSOFIA, LETRAS E CIÊNCIAS HUMANAS

DEPARTAMENTO DE SOCIOLOGIA

PROGRAMA DE PÓS-GRADUAÇÃO EM SOCIOLOGIA

\title{
A crise do Estado boliviano e a autonomia indígena
}

\author{
Rafaela Nunes Pannain
}

Tese de doutorado submetida ao Programa de Pós-graduação em Sociologia Departamento de Sociologia da Faculdade de Filosofia, Letras e Ciências Humanas da Universidade de São Paulo, como parte dos requisitos exigidos para a obtenção do título de Doutora em Sociologia.

Orientador: Prof. Dr. Brasilio João Sallum Júnior

São Paulo

2014

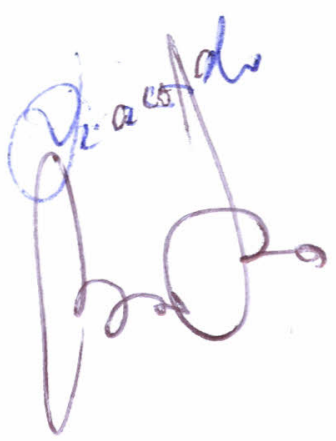


FACULDADE DE FILOSOFIA, LETRAS E CIÊNCIAS HUMANAS

DEPARTAMENTO DE SOCIOLOGIA

PROGRAMA DE PÓS-GRADUAÇÃO EM SOCIOLOGIA

\title{
A crise do Estado boliviano e a autonomia indígena
}

\author{
Rafaela Nunes Pannain
}

\begin{abstract}
Tese de doutorado submetida ao Programa de Pós-graduação em Sociologia Departamento de Sociologia da Faculdade de Filosofia, Letras e Ciências Humanas da Universidade de São Paulo, como parte dos requisitos exigidos para a obtenção do título de Doutora em Sociologia.
\end{abstract}

Orientador: Prof. Dr. Brasilio João Sallum Júnior

São Paulo

2014 
Para a Nação Guarani

e para meus pais, Vera e Eduardo. 


\section{Agradecimentos}

Agradeço a todos que compartilharam comigo seu tempo, suas experiências e suas impressões sobre o processo político boliviano e a construção da autonomia indígena nesse país.

Ao professor Brasilio Sallum Jr., pela orientação, o apoio e o entusiasmo com o qual aceitou orientar esta pesquisa. Muito do que é apresentado neste trabalho é resultado do diálogo enriquecedor que tecemos ao longo dos últimos anos.

À Coordenação de Aperfeiçoamento de Pessoal de Nível Superior (Capes) e à Fundação de Amparo à Pesquisa do Estado de São Paulo (Fapesp) pelo financiamento fundamental para a elaboração desta pesquisa.

Aos professores Rossana Rocha Reis e Salvador Schavelzon, pela importante contribuição na banca de qualificação.

Aos professores Charles Freitas Pessanha, Vivian Grace Fernández-Dávila Urquidi, Angela Maria Alonso e Rossana Rocha Reis pela participação na banca de defesa desta tese.

Aos meus interlocutores em La Paz que, com generosidade, me ensinaram muito: Adolfo Mendoza, Debla Velasco, Diego, Edwin Prada, Felipe Quispe, Fernanda Wanderley, Jesús Jilamita, José Ortiz, Juan Guarayo, Oscar Vega, Patricia Costas, Patricia Ramos, Paulino Gurachi, Pedro Portugal, Ramiro Molina, Ramiro Orias, Silvia Mejia, Tata Javier Lara e Xavier Albó. A Inti Tonatiuh Rioja e à Fundación Boliviana para la Democracia Multipartidaria. Aos representantes do Ministério de Autonomias, ministra Claudia Peña e vice-ministro de autonomias indígenas, Gonzalo Vargas. E, 
especialmente, a Santiago Daroca, Nelly Arista e ao amigo cochabambino, Sergio Castro, por compartilharem comigo suas impressões sobre o processo político boliviano e me ajudarem na realização do trabalho de campo.

Aos companheiros com quem viajei pelo território guarani de Charagua: Belarmino Solano, Marco, Marco Antonio Graciano e Julian Chacae e, em especial, a Santiago Puerta, pela ajuda fundamental para que eu pudesse conhecer o processo de autonomia guarani em Charagua. Ao CIPCA e às autoridades guaranis que me permitiram acompanhar este processo.

Às comunarias, comunarios e mburuvichas de Kuarirenda, Aguarati, Coropo e San Antonio, por me receberem tão bem e compartilharem comigo suas experiências e comida.

Aos mburuvichas de Parapitiguasu, Avilio Vaca e Edith Ruíz, por me abrirem as portas da capitania.

Às autoridades de Charagua Norte, mburuvicha Ruth Yarigua e Pura Tavarillo.

Também em Charagua, a Carlos Bazán, Carlos Sánchez e Marcelo Alberto Quelca.

Aos colegas do Grupo de Trabalho da Clacso "Pueblos indígenas en lucha por las autonomías: Movimientos y políticas en América Latina”, em especial a Pavel López, pelo convite para acompanhar a reunião do grupo em Tarija e a sua viagem pelo Chaco boliviano para encontrarmos com a Asamblea del Pueblo Guaraní. A Hernan Ruiz e aos mburuvichas, Quintin Valeroso e Heidi Aruchari, com quem pudemos compartilhar essa experiência. 
Aos professores do Departamento de Sociologia, pelo diálogo estabelecido durante os meus anos de doutorado. Em especial, ao professor Flavio Peirucci (in memorian), por receber-me de braços abertos no Departamento.

A Angela Ferraro, Vicente Sedrângulo Filho e Gustavo Mascarenhas, que, na Secretaria de Pós-Graduação, sempre se mostraram dispostos a ajudar-nos nos diferentes trâmites administrativos.

À professora Vera da Silva Telles e aos colegas do seminário de projetos, pelos comentários sobre o projeto inicial desta pesquisa.

Ao professor Lúcio Kovarick e demais colegas do grupo de estudos sobre movimentos sociais.

À professora Vivian Urquidi e demais companheiros do grupo de pesquisa Observatório Interdisciplinar de Políticas Públicas, pelos ricos debates sobre a questão indígena na América Latina. A participação no grupo foi importante não apenas pelas leituras realizadas, que influenciaram diretamente esta pesquisa, mas, principalmente, por representar um espaço de troca, debate e construção, que dá mais sentido ao trabalho acadêmico.

À professora Allyson Benton, a Mariana Llanos e os colegas da ECPR Summer School on Latin American Studies, pelos comentários em uma versão anterior de parte desta tese.

Aos colegas que comentaram artigos sobre esta pesquisa nos VIII e IX Congressos da Associação Latino-Americana de Sociologia (Alas), no VII Congresso Latino-Americano de Ciência Política e na VII ECPR General Conference. 
À minha amiga e professora de espanhol e aymara, Ilse, por receber-me em La Paz, e aos amigos, Anne, Elena, Gabriel, Gilber, Mara e Ruben, sem os quais a vida nessa cidade não teria tido a mesma graça.

Ao Christian, por sempre apoiar a realização desta tese; pelas salsas, salsas e tudo mais.

Aos amigos com quem compartilho o interesse pelo processo político boliviano e com quem pude trocar impressões e, em algum momento, dividir uma casa em La Paz: Aiko Amaral, Clayton Mendonça, Heloisa Gimenez, Renata Moraes. E, em especial, a Gladstone Leonel Jr. e Liu Leal, companheiros tão queridos.

A Sue Iamamoto, pela amizade e a grande generosidade em compartilhar sua biblioteca, experiências, impressões e tantos bons momentos nos meses que dividimos um teto em La Paz.

A Caroline Freitas, pelo grande apoio nos momentos difíceis do campo e da elaboração desta tese, pelas conversas sobre a Bolívia e por abrir a sua biblioteca para a minha pesquisa.

Aos amigos que tão bem me receberam na USP e em São Paulo, por fazerem desta cidade um lugar feliz: Ana Carolina, Catalina, Célia, Massimo e Tulio.

A Fernanda, Wendel e Flávia, minha família em São Paulo, provas de que existe amor nesta cidade.

Ao Leonardo, pelo que construímos e aprendemos juntos.

Aos amigos imprescindíveis, que, apesar da distância, mantêm-se presentes: Alejanda, Drouyn, Isabelle, Gustavo, Manu, Melisa, Michael e Paula. 
À Paola, pela amizade, pelo apoio e pelas muitas horas de conversa sobre esta pesquisa.

À Carol, pela presença constante, pela ajuda nesta tese, e em todos os momentos, e porque, juntas, podemos rir de quase tudo.

Ao Caio, porque costó... pero llegamos.

À minha irmã, Camila, fonte de inspiração e apoio.

Ao meu avô, Octávio, que compartilha comigo o entusiasmo em apreender o guarani, pelo exemplo de vida.

Aos meus pais, Vera e Eduardo, pelo apoio incondicional à realização desta tese e por sempre estarem presentes. 


\section{Resumo}

Neste trabalho, parto da última crise política boliviana para mostrar como a forte mobilização social, entre os anos de 2000 e 2005, rompeu com as fronteiras do campo da política institucional. Apesar da ascensão de representantes dos setores indígenas e camponeses, em 2006, a crise política não chegou ao fim. Ela adquiriu novas características. A partir de 2006, os papéis se inverteram: aqueles que haviam sido deslocados do controle do poder político nacional buscavam a desestabilização institucional; enquanto os movimentos sociais, que haviam levado à desestabilização dos governos anteriores, colocavam-se como defensores da nova ordem. Com a superação da crise e o retorno à "conjuntura ordinária", as fronteiras do campo foram redefinidas e novos espaços de participação foram criados para os atores indígenas. A redefinição do campo da política institucional veio acompanhada do projeto de criação do Estado Plurinacional, que aponta para o reconhecimento de distintas formas de organizações sociais e políticas existentes dentro do território boliviano. Este trabalho procura explicar igualmente como a rearticulação do campo da política institucional influenciou na reestruturação estatal anunciada. Para tanto, analiso os debates sobre as autonomias indígenas e a criação da autonomia guarani no município de Charagua.

Palavras-chave: 1. Bolívia, 2. Crise política, 3. Autonomia indígena, 4. Organizações sociais indígenas, 5. Assembleia do Povo Guarani, 6. Charagua 


\begin{abstract}
The last Bolivian political crisis and the important associated social mobilization, between the years of 2000 and 2005, rendered the boundaries of the institutional politics field fluid. Despite the rising of indigenous and peasants groups in 2006, the political crisis was not overcome. Since 2006, the long standing roles in Bolivian politics have changed: those who had been replaced in control of national political power now tried to disrupt institutional power; the social movements, whose actions worked to destabilize previous governments, now became the defenders of the new order. Once the political crisis of those years was overcome, the boundaries of the field were restructured and new spaces for the participation of indigenous actors were created. The redefinition of the institutional politics field resulted in the creation of the "Plurinational State of Bolivia", where different forms of social and political organization that operate in Bolivia are given recognition in the redefinition of the state. This work also aims to shed light on how the reorganization of the institutional politics field has influenced the announced state restructure. With this purpose, I analyse the debates concerning the indigenous autonomies and the experience of the Guarani autonomy in Charagua.
\end{abstract}

Key-words: 1. Bolivia, 2. Political crisis, 3. Indigenous autonomy, 4. Indigenous organizations, 5. Asamblea del Pueblo Guaraní, 6. Charagua 


\section{Résumen}

En este trabajo parto de la última crisis política boliviana para mostrar cómo la fuerte mobilización social, entre 2000 y 2005, rompió con las fronteras del campo de la política institucional. Con el ascenso de representantes de los sectores indígenas y campesinos em 2006, la crisis adquiere nuevas características. Se invierten los roles: aquéllos que habían sido desplazados del control político nacional buscaban la desestabilización institucional, mientras los movimientos sociales, que habían desestabilizado los gobiernos precedentes, eran los defensores del nuevo orden. Una vez terminada la crisis, y con el retorno a la "coyunctura ordinaria", las fronteras del campo fueron redefinidas y los actores indígenas crearon nuevos espacios de participación. La redefinición del campo de la política institucional vino de par con el proyecto de creación del Estado Plurinacional, que indica el reconocimiento de diferentes formas de organización sociales y políticas existentes en el territorio boliviano. Además, este trabajo procura explicar cómo la rearticulación del campo de la política institucional ha influído en la reestructuración estatal anunciada. Con este objetivo, analizo los debates sobre las autonomías indígenas y la creación de la autonomía guaraní en el municipio de Charagua.

Palabras clave: 1. Bolivia, 2. Crisis política, 3. Autonomía indígena, 4. Organizaciones sociales indígenas, 5. Asamblea del Pueblo Guaraní, 6. Charagua 


\section{Lista de Siglas e Abreviaturas}

ADN - Acción Democratica Nacionalista

AAI - Alianza Andrés Ibáñez

AIOC - autonomia indígena originário camponesa

APB - Autonomías para Bolivia

APG- Asamblea del Pueblo Guaraní

AS - Alianza Social

ASP - Asamblea para la Soberanía de los Pueblos

Ayra - Movimiento Ayra

$\mathrm{BIC}$ - Bloque Indígena Campesino

BNDES - Banco Nacional de Desenvolvimento Econômico e Social

Cejis - Centro de Estudios Jurídicos e Investigación Social

Cidob - Confederación de Pueblos Indígenas de Bolivia

Clacso - Conselho Latino-americano de Ciências Sociais

CN-PI - Concertación Nacional - Patria Insurgente

CNRJB - Confederación Nacional de Rentistas Jubilados de Bolivia

CNTCB - Confederación Nacional de Trabajadores Campesinos de Bolivia

COB - Central Obrera Boliviana

Cofecay - Consejo de Federaciones Campesinas de los Yungas

Conalde - Consejo Nacional Democratico

Conalcam - Coordinadora Nacional por el Cambio

Conamaq - Consejo Nacional de Ayllus y Markas del Qullasuyu

Condepa - Conciencia de Patria

Conisur- Consejo Indígena del Sur 
CNPB - Confederación Nacional de Panificadores de Bolivia

COR - Central Obrera Regional (COR) de El Alto

CPEMB - Confederación de Pueblos Étnicos Moxeños de Beni

CPESC - Coordinadora de Pueblos Étnicos de Santa Cruz

CPIB - Central de los Pueblos Indígenas del Beni

CSCB - Confederación Sindical de Colonizadores de Bolivia

CSUTCB - Confederación Sindical Única de los Trabajadores Campesinos de Bolivia

CTLCC - Confederación del Transporte Libre del Campo y la Ciudad

EGTK - Ejército Guerrillero Tupac Katari

Fedecor - Federación Cochabambina de Regantes

Fejuve- El Alto - Federación de Juntas Vecinales de El Alto

Fencomin - Federación Nacional de Cooperativas Mineras de Bolivia

FNMCB-BS - Federación Nacional de Mujeres Campesinas de Bolivia "Bartolina

Sisa”

FSTMB - Federación Sindical de Trabajadores Mineros de Bolivia

Gampi - Grande Assembleia dos Povos Indígenas

Inra - Instituto Nacional de Reforma Agraria

IOC - Indígena Originário Camponês

IPSP - Instrumento Político por la Soberanía de los Pueblos

IU- Izquierda Unida

LDA - Lei de Descentralização Administrativa

LMAD - Lei Marco de Autonomias e Descentralização

LPP - Lei de Participação Popular

MAS-IPSP - Movimiento al Socialismo - Instrumento Político por la Soberanía de los Pueblos 
MBL - Movimiento Bolivia Libre

MCSFA - Movimiento Ciudadano San Felipe de Austria

MIP - Movimiento Indio Pachakuti

MIR - Movimiento de Izquierda Revolucionario

MIR-NM- Movimiento de Izquierda Revolucionaria - Nueva Mayoría

MITKA - Movimiento Indio Tupac Katari

MNR - Movimiento Nacionalista Revolucionario

MNR-A3 - Movimiento Nacionalista Revolucionário - A3

MNR-FRI- Movimiento Nacionalista Revolucionário - Frente Revolucionario de

Izquierda

MOP - Movimiento Originario Popular

MRTK - Movimiento Revolucionario Tupac Katari

MST-B - Movimiento de Trabajadores Campesinos e Indígenas Sin Tierra da Bolivia

NCPE - Nueva Constitución Política del Estado

NFR - Nueva Fuerza Republicana

OIT - Organização Internacional do Trabalho

ONG - Organização Não Governamental

ONU - Organização das Nações Unidas

OTB - Organização Territorial de Base

PCB - Partido Comunista Boliviano

PIR - Partido Izquierda Revolucionaria

PNUD - Programa das Nações Unidas para o Desenvolvimento

Podemos - Poder Democratico y Social

POR - Partido Obrero Revolucionário

Radepa - Razón de Patria 
Relaju - Rede Latino-Americana de Antropologia Jurídica

Repac - Representação Presidencial para a Assembleia Constituinte TCO - Tierra Comunitaria de Origen

Thoa - Taller de Historia Oral Andina

Tioc - Território Indígena Originário Camponês

Tipnis - Territorio Indígena Parque Nacional Isiboro Sécure

UDP - Unidad Democratica y Popular

UJC - Unión Juvenil Cruceñista

UN - Unidad Nancional

Unasul - União das Nações Sul-americanas

Usaid - United States Agency for International Development

YPFB - Yacimientos Petroliferos Fiscales Bolivianos 


\section{Sumário}

$\begin{array}{ll}\text { Introdução } & 19\end{array}$

1.0. Capítulo 1- Os indígenas e o Estado boliviano

1.1. A Revolução Nacional de 1952 e o novo Estado

59

1.2. O ciclo de ditaduras militares (1964-1982)

1.3. A democracia pactuada e excludente e a Nova Política Econômica

1.4. Indígenas e camponeses: a formação das organizações

1.5. Remendando a "democracia pactuada": as reformas constitucionais

dadécada de 1990

1.6. Indígenas e camponeses: participação no campo partidário

2.0. Capítulo 2 - Crise Política: o descompasso entre o Estado e asociedade

2.1. Da luta pela água à construção da autonomia radical 100

2.2. O movimento cocaleiro

2.3. A marcha indígena pela assembleia constituinte

2.4. Mobilização popular, repressão estatal e fuga de um presidente 

constitucional

\section{Plurinacional}

4.1. A disputa pelos marcos da autonomia indígena guaranis de Charagua

Considerações Finais 
Terras Comunitárias de Origem

Anexo 6 - Anexo Fotográfico 


\section{Introdução}

Dado que ninguna admisión de derechos podía provenir graciosamente de los grupos dominantes-interesados por razones muy terrenales en mantener a los grupos étnicos como verdaderas "colonias internas"- las premisas sociopolíticas de tal reconocimiento sólo podían emerger de los propios pueblos indios, una vez que éstos lograran aprovechar las mismas contradicciones y la dinámica de la sociedad nacional para acumular suficiente fuerza política (Héctor Díaz-Polanco, 2006 [1991]: 10).

O preâmbulo da nova Constituição boliviana, promulgada em sete de fevereiro de 2009, afirma: as "lutas do passado" estão na base da construção do novo Estado. No artigo primeiro, esse Estado é definido como "Unitário Social de Direito Plurinacional Comunitário, livre, independente, soberano, democrático, intercultural, descentralizado e com autonomias". O artigo seguinte, ao tratar da livre determinação dos povos indígenas da Bolívia, evidencia que o direito à autonomia estende-se aos povos e nações indígenas desse país ${ }^{1}$.

A nova Constituição foi redigida em um momento de transformação do campo político boliviano, que culminou na eleição de Evo Morales à presidência do país e a inclusão de inúmeros representantes dos movimentos sociais na Assembleia Constituinte, convocada pelo recém-eleito presidente. Neste sentido, embora a transição para o regime democrático tenha ocorrido no final da década de 1970 e início da

\footnotetext{
${ }^{1}$ Uso ao longo deste trabalho as expressões "povos e nações indígenas" ou "povos e nações indígena originário camponeses" por serem os termos adotados atualmente pelas organizações sociais bolivianas e na Constituição de 2009.
} 
seguinte, é possível dizer que ela persistiria até a primeira década do século XXI, quando representantes dos setores subalternos, pela primeira vez, tiveram a oportunidade de participar de posições importantes dentro do Estado.

Começarei apresentando a Bolívia e alguns elementos históricos que permitam apreender a relação entre os diferentes povos e nações indígenas com o poder central ao longo do tempo. O objetivo é apresentar algumas das diferentes formas de disputa, negociação e subordinação que foram adotadas por esses povos ou que lhes foram impostas.

\section{A Bolívia e os bolivianos: uma aproximação}

Em 2012, a população boliviana era de um pouco mais de dez milhões de habitantes, distribuídos em uma extensão territorial de aproximadamente um milhão de quilômetros quadrados ${ }^{2}$. Viajando pela Bolívia, entendi que, em muitos sentidos, há diferentes realidades dentro do território nacional. Como a maioria dos países latinoamericanos, a Bolívia é um lugar de contrastes. Esses, no caso boliviano, não se resumem apenas ao abismo existente entre a maioria da população, que não tem reconhecidos na prática seus direitos econômicos, sociais e culturais, e uma pequena parcela, que controlou política e economicamente o país ao longo de sua história ${ }^{3}$. Como em outros países do continente, essa divisão coincide, em grande medida, com as diferentes características físicas dos bolivianos, sendo que a minoria é formada por descendentes de europeus e mestiços e a maioria composta, quase exclusivamente, por pessoas que o olhar estrangeiro identifica como indígenas. Apenas com o passar do

\footnotetext{
${ }^{2}$ Fonte: Instituto Nacional de Estadística. www.ine.gob.bo, consultado em 18/12/2013.

${ }^{3}$ Sobre direitos econômicos, sociais e culturais, ver: http://www.oas.org/dil/port/1966\%20Pacto\%20Internacional\%20sobre $\% 20$ os $\% 20$ Direitos $\% 20$ Econ $\%$ C3 \%B3micos, $\% 20$ Sociais $\% 20 \mathrm{e} \% 20$ Culturais.pdf, consultado em 18/12/2013.
} 
tempo e a vivência no país andino, foram percebidas as diferentes nuances de contrastes que me pareceram tão gritantes em um primeiro momento.

Uma disparidade, que tampouco é exclusiva desse país, é aquela entre o campo e as cidades no que se refere aos índices de desenvolvimento humano e o acesso a serviços públicos, como saúde, distribuição de água e coleta de esgoto, telecomunicação e eletricidade ${ }^{4}$.

Outra divisão central é a que opõe as Terras Baixas às Terras Altas. Trata-se de uma divisão tanto geográfica quanto política, econômica, cultural e étnica.

A Cordilheira dos Andes cruza o continente sul americano do extremo sul até a Venezuela, ocupando a parte ocidental da Bolívia. As Terras Altas encontram-se, assim, na parte ocidental do país e englobam a região andina dos departamentos de La Paz, Cochabamba, Chuquisaca, Oruro e Potosí. Entre as Cordilheiras Orientais e Ocidentais dos Andes, encontra-se a grande planície conhecida como Altiplano, situada a mais de 3000 metros de altitude. Faz parte igualmente das Terras Altas, uma região subandina de vales, que inclui parte dos departamentos de Cochabamba, Chuquisaca, Tarija, Potosí e La Paz ${ }^{5}$. Essa região está localizada entre 2000 e 3000 metros de altitude. Nas Terras Altas, encontram-se importantes cidades como La Paz, capital administrativa do país, El Alto, Cochabamba e Potosí. Na região norte e oriental do país, encontram-se as Terras

\footnotetext{
${ }^{4}$ Essas diferenças existem mesmo entre bairros de grandes cidades como La Paz e Cochabamba, mas é ainda mais importante a diferença entre centros urbanos e comunidades rurais. Segundo o censo realizado em 2012, das 2.812.715 residências do país, 66\% tinha acesso ao serviço de água encanada e 39\% a uma rede de recolhimento de esgoto e, apesar da Bolívia ser um grande produtor de gás natural, quase um quarto da sua população cozinha com lenha. Fonte: Instituto Nacional de Estadística, Bolivia Caracteristicas de Población y Vivienda, Censo Nacional de Población y Vivienda 2012.

Sobre as diferenças entre os índices de desenvolvimento humano entre o campo e as cidades, destaco alguns dados do informe elaborado pelo PNUD em 2002: a taxa de mortalidade infantil por cada 100 mil nascimentos era de 50 para os setores urbanos e 90 para os rurais; a taxa de analfabetismo era de 5,3\% no primeiro caso e 33,7\%, no segundo; a média de anos de escolaridade da população acima de 25 anos era de 8,99 nas cidades, contra apenas 3,01 no campo.

${ }^{5}$ Ver anexos 1 e 2: Mapa político e mapa físico da Bolívia.
} 
Baixas, as quais incluem áreas de floresta, pampas e semiáridos dos departamentos de Santa Cruz, Beni, Pando e Tarija.

O quéchua é atualmente a língua mais falada na Bolívia depois do espanhol. Nos censos populacionais realizados em 2001 e 2012, 30,7\% e 18,5\%, respectivamente, dos bolivianos maiores de 15 anos se autoidentificaram como quéchuas ${ }^{6}$. A população quéchua boliviana é constituída por diferentes povos indígenas conquistados pelos incas, aos quais a língua quéchua foi imposta. A segunda maior população indígena do país é formada pelos aymaras, que representam, de acordo com os censos apontados, $25,2 \%$ e $17,2 \%$ dos bolivianos ${ }^{7}$. Apesar dos diferentes grupos étnicos de fala aymara terem sido igualmente partes do Império Inca, muitos não adotaram o quéchua durante o seu domínio. Segundo Tristan Platt, desenvolveu-se uma relação ao mesmo tempo "simétrica" e "desequilibrada" entre as autoridades aymaras e o líder Inca, que reconheceu tais autoridades como seus representantes nos senhorios aymaras e "construiu sua nova ordem sobre os fundamentos sociais pré-existentes, ainda que esses fundamentos adquirissem muitas vezes novas funções dentro do Estado centralizado" (1987: 102, tradução minha). Este foi o caso, por exemplo, do uso do trabalho comunal obrigatório e rotativo para a produção de milho (ibid.).

Atualmente, a maioria dos aymaras vive na região do Altiplano boliviano e os quéchuas, nos Vales. Contudo, ainda que para o olhar externo a população das Terras Altas se divida, principalmente, entre quéchuas e aymaras, essas identidades "amplas" nem sempre são adotadas internamente pelos atores. Há uma multiplicidade de identidades indígenas locais. Neste sentido, o Consejo Nacional de Ayllus y Markas del

\footnotetext{
${ }^{6}$ Nem todos que se autoidentificam com algum povo ou nação indígena falam a sua língua, assim como nem todos que falam alguma língua indígena reivindicam uma identidade indígena.

${ }^{7}$ Fonte: Instituto Nacional de Estadística. www.ine.gob.bo, consultado em 18/12/2013.
} 
Qullasuyu (Conamaq), principal organização indígena das Terras Altas, reivindica ser o governo de 16 nações ${ }^{8}$.

O nome da organização indígena mencionada faz referência ao Qullasuyu, região do Império Inca que englobava uma área das Terras Altas bolivianas, o Norte do Chile e da Argentina e o Sul do Peru. Como apresentarei, o discurso sobre a reconstrução do Qullasuyu está presente na fala atual de alguns atores indígenas. Ademais, o nome Conamaq faz referência a duas formas andinas de organização, o “ayllu" e a "marka". No presente, o ayllu é, no Altiplano, o equivalente à comunidade indígena ${ }^{9}$. Já as markas são macro regiões formadas por vários ayllus, ou seu centro administrativo ${ }^{10}$.

Estudando os ayllus e markas do Norte de Potosí, Tristan Platt aponta que a invasão espanhola, com a qual parte dos senhorios aymaras havia colaborado na luta contra o exército inca, levou a uma fragmentação das Confederações Aymaras. Além disso, se com o Império Inca as autoridades aymaras pagavam seus "tributos" por meio do envio de mão-de-obra; com a dominação espanhola, além da mit'a, passaram a ser cobrados igualmente tributos monetários. Mais uma vez, as autoridades locais assumiram o papel de intermediários. E, dessa forma, em contrapartida, o governo colonial reconhecia certa autonomia das comunidades indígenas.

\footnotetext{
${ }_{9}^{8}$ Atualmente há uma disputa interna dividindo o Conamaq. Voltarei a esta disputa no capítulo 4.

9 “Atualmente, os termos comunidade ou ayllu designam, em geral, unidades com fronteiras territoriais relativamente delimitadas que se expressaram e traduziram, historicamente, em seus títulos de propriedade que podem remontar às antigas composições e títulos coloniais e/ou aos que receberam depois da Reforma Agrária de 1953, com a particularidade de que explícita ou implicitamente têm a figura do que se conhece juridicamente como propriedade pro-indiviso (ainda que não seja especificada como tal), ou seja, uma propriedade outorgada a uma coletividade ou lista de pessoas [...] O termo comunidade ou ayllu designa, portanto, essa unidade maior com um território delimitado mas também as suas subdivisões porque em geral se tinha uma estrutura segmentaria desde os níveis maiores até os níveis mínimos e indivisíveis (desde a comunidade ou ayllu maior até a fazenda, rancho ou cabildo) [...]" (Urioste et al., 2007: 29-30, tradução minha).

10 "Marka no idioma aymara tem vários significados. A partir da memória coletiva, representa a união das comunidades ou ayllus, a união das parcialidades de Aransaya e Urinsaya. Por outro lado, significa povoado central ou administrativos de vários ayllus" (Guery et al., 2010: 5, tradução minha).
} 
Nos primeiros anos da Bolívia republicana, criada com a independência do domínio espanhol, em 1825, os tributos pagos pelas comunidades indígenas foram fundamentais para a manutenção do Estado. Contudo, a relação entre esse e o ayllu entraria em um novo momento. Para consolidar a propriedade privada e estimular um mercado de terras, substituiu-se a cobrança coletiva de impostos, por uma individual (Platt, 1987: 64). Como explica Platt:

Temos assim na República Boliviana do século XIX o espetáculo paradoxo de uma casta dominante empenhada em incorporar as massas andinas no modelo europeu de "modernidade liberal", enquanto elas decidem defender as bases comunitárias do apartheid colonial. De seu refúgio nos ayllus ou "comunidades de índios livres", os aymaras se lançaram, com crescente tenacidade, à defesa do antigo pacto de reciprocidade entre ayllu e Estado (ibid.: 65, tradução minha).

Durante o século XIX, em alguns lugares do Altiplano, e principalmente na região dos Vales, as terras comunitárias foram progressivamente ocupadas por haciendas, em um sistema semelhante ao sistema gamonal peruano descrito por José Carlos Mariátegui (2010). Tal sistema era caracterizado pelas relações de servidão (pongueaje) às quais estavam submetidas as populações indígenas. Foi somente na década de quarenta do século XX que o presidente boliviano Villarroel decretou o fim do sistema de servidão.

No final do século XIX, a exploração da prata no Altiplano foi substituída pela de estanho, como eixo da economia nacional. Com essa mudança, a história se repetia e a exploração das riquezas do território boliviano não beneficiou a maioria da população boliviana, nem o desenvolvimento de um Estado forte; em função da influência política dos grandes "barões do estanho" e pelo percentual mínimo da exploração do metal que era repassado aos cofres públicos em forma de impostos. 
Após a Guerra Federal (1898-1899), a sede do poder político foi transferida de Sucre para La Paz. O Ocidente mantinha-se assim como centro político do país, além de principal região econômica, já que a mineração estava concentrada nos departamentos de Potosí e Oruro.

Diferentemente do Ocidente, no Oriente boliviano, os povos e nações indígenas representam uma minoria demográfica. A população indígena demograficamente mais importante das terras baixas é formada pelos guaranis, que representam 1,54\% dos bolivianos maiores de 15 anos, segundo o censo de 2001 , e $0,85 \%$, segundo o censo realizado em $2012^{11}$. Além dos guaranis, são reconhecidos 33 outros povos indígenas das Terras Baixas.

O Oriente boliviano apresenta grandes diferenças internas. Apontarei algumas características relevantes da região, apresentando brevemente a Nação Guarani, protagonista do processo de conversão à autonomia indígena do município de Charagua, no qual foi realizado parte do trabalho de campo para esta pesquisa.

Os guaranis conseguiram resistir às tentativas coloniais e republicanas de sujeição ao poder central até o final do século XIX, quando ocorreu o massacre de Kuruyuki (1892). O exército boliviano defendia, naquela disputa, os interesses dos pecuaristas, para os quais muitos guaranis foram trabalhar como escravos depois da derrota. Parte da população guarani imigrou para a Argentina e outra foi integrada às missões católicas, já que no Oriente as missões jesuíticas haviam sido um importante instrumento de colonização do Império Espanhol.

Entre 1915 e 1948, a política estatal em relação aos guaranis buscava a sua secularização e o controle de seus territórios (Albó, 2007). Um dos resultados trágicos desse processo foi o grande decréscimo demográfico da população guarani.

\footnotetext{
${ }^{11}$ Fonte: Instituto Nacional de Estatística (INE) www.ine.gob.bo, consultado em 18/12/2013.
} 
O Estado boliviano esteve bastante ausente do Oriente até 1940 (Soruco, 2008: 35). Entre o final do século XIX e o início do século seguinte, a extração de borracha dinamizou a economia local, articulando-a com o mercado mundial e atraindo migrantes do Ocidente boliviano e estrangeiros (ibid.).

Talvez ainda menos que nas Terras Altas, nas Terras Baixas não é possível encontrar uma homogeneidade entre as diferentes nações e povos indígenas. Tampouco é possível tratar desta região a partir de uma perspectiva econômica que aproxime regiões tão distintas como o Chaco, a Amazônia e a atual região agroindustrial do departamento de Santa Cruz.

A despeito das limitações implícitas na generalização do uso das dicotomias Ocidente/Oriente e Terras Baixas/Terras Altas, recorrerei a elas ao longo deste trabalho porque, em primeiro lugar, elas são usadas pelos atores e autores; em segundo lugar, como minha análise parte da política nacional, as diferenças entre os polos das dicotomias são mais pertinentes do que aquelas dentro de cada região. Assim, os distintos povos e nações indígenas estão articulados em organizações que refletem as oposições entre Terras Baixas e Terras Altas, e o apoio ou oposição ao governo Evo Morales nos diferentes departamentos do país durante parte do período estudado indicam uma divisão entre Ocidente e Oriente.

\section{A identidade indígena}

A publicação do censo populacional realizado em 2012 reacendeu o debate em torno da identificação étnica dos bolivianos. No censo, 40,57\% da população boliviana acima de 15 anos se autoidentificou como pertencente a alguma "nação ou povo indígena originário camponês". Esse número representa uma redução de $35 \%$ em 
relação ao total de bolivianos que haviam se autoidentificado como pertencentes a algum povo indígena no censo realizado em 2001. A partir da divulgação dos novos dados, iniciou-se um debate: alguns questionavam a forma por meio da qual a pergunta do censo de 2012 havia sido elaborada, outros questionavam a pertinência do recémcriado Estado Plurinacional, argumentando, com base no censo, que a Bolívia seria um país mestiço.

A autoidentificação, recurso usado nos dois censos mencionados, é o critério comumente aceito para definição de "indígena". Entretanto, como mostram os resultados do censo e os debates acadêmicos e políticos que o seguiram, existem muitas nuances que um dado estatístico como esse não consegue captar.

Independente das razões para a diferença entre os resultados, parece-me pertinente fazer alguns apontamentos sobre a questão da identidade indígena. Primeiramente, é preciso ter em mente que as identidades são fluidas e objeto da ação política (Martin, 1994). Veremos como no caso boliviano, a partir da Revolução Nacional de 1952, houve um projeto estatal de afirmação da identidade camponesa dos indígenas, que deveriam formar sindicatos rurais como meio de articulação com o Estado. Na década de 1970, contudo, houve um movimento de politização da identidade indígena no Altiplano que, poucos anos depois, seria acompanhado por um processo de articulação de povos indígenas das Terras Baixas.

Apesar desse processo estar associado a uma conjuntura política determinada, com o fortalecimento de certas correntes intelectuais bolivianas e a reconstituição da democracia no país, ele está inserido igualmente em um contexto regional favorável, já que nas últimas décadas assistimos, em diferentes países da América Latina, uma politização da identidade indígena. Díaz-Polanco afirma que "desde os anos oitenta, o perfil político da chamada problemática étnica se acentuou em diversos países da 
região" (2006 [1991]: 111, tradução minha). O autor mexicano destaca que, dado o longo trajeto do movimento indígena no continente, a novidade das últimas décadas consistiria na mudança na natureza e na qualidade desses movimentos em alguns países, que teriam repercussões regionais (ibid.). Essa irrupção dos movimentos indígenas em diferentes países teria em comum a articulação com processos políticos que ultrapassam o âmbito comunal e regional, e que tiveram como consequência a aparição de "novas

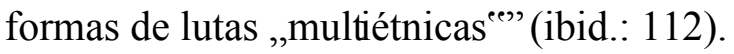

Uma articulação multiétnica implica na necessidade de adoção de uma identidade comum. Dessa forma, é necessário um processo de politização da identidade "indígena", que fora criada como produto colonial, para unificar populações com características muito distintas $^{12}$. Como explica Bonfil Batalla:

A categoria de índio, na verdade, é uma categoria supraétnica que não denota nenhum conteúdo específico dos grupos que abarca, mas uma relação particular entre eles e outros setores do sistema social global do qual os índios fazem parte. A categoria índio denota a condição de colonizado e faz referência necessariamente à relação colonial (1972: 4, tradução minha).

Foi preciso, então, re-significar uma identidade construída por atores externos. Identidade que, ao longo da história, foi, e continua sendo, carregada de referências negativas; dificultando sua adoção por uma parte da população.

A partir dos movimentos indígenas, o ato consciente de "apagar" as fronteiras entre grupos bastante distintos busca o fortalecimento daqueles que lutam contra o que

\footnotetext{
12 O meu trabalho de campo em comunidades guaranis do município de Charagua indica que a reapropriação da identidade indígena, pelo menos no caso pesquisado, tem incidência distinta dentro e fora das comunidades. Enquanto no discurso da organização das capitanias guaranis, a Asamblea del Pueblo Guaraní (APG), está presente a reivindicação da identidade indígena, em conversas e discursos em assembleias comunais, a identidade indígena aparecia, às vezes, como uma categoria estrangeira, imposta de fora.
} 
há de negativo em "ser indígena" na Bolívia: a desqualificação de formas de organização social e políticas distintas das ocidentais e o racismo ${ }^{13}$.

Não obstante esse processo de unificação, persistem diferenças regionais no que se refere à identidade reivindicada ${ }^{14}$. Enquanto povos das Terras Baixas reivindicam-se mais comumente como indígenas, nas Terras Altas é mais usual falar de "povos originários”, e, em alguns casos, há uma articulação entre a identidade originária e camponesa, ou apenas uma adoção desta última. A fórmula "povos e nações indígena originário camponeses" presente na Constituição de 2009, assim como as identidades apontadas, é fruto de um processo histórico e político específico. No caso da fórmula abarcante, ela é resultado de um debate dentro do contexto de reformulação do texto constitucional, no qual se almejava a equiparação de direitos a diferentes populações, independentemente de como elas se identificam.

O vasto debate em torno da pertinência e do uso das identidades "indígenas" ou “originárias” na Bolívia passa, inevitavelmente, pela questão da mestiçagem cultural, resultado de mais de 500 anos de convivência entre os povos que se encontravam na América no momento da invasão espanhola e aqueles que migraram desde então.

A mestiçagem se acelerou a partir da migração para as cidades de um grande percentual da população rural. Em muitos casos, é mantida uma ligação entre os imigrantes e suas comunidades de origem, a partir do cumprimento de

\footnotetext{
${ }^{13}$ A existência de um forte racismo contra a população com características indígenas, notada ao longo do trabalho de campo, foi corroborada por diferentes episódios relatados a mim por representantes das organizações indígenas de diferentes regiões do país e de comunidades guaranis, como também por representantes de setores médios urbanos.

Nesse sentido, Oscar Vega Camacho fala da necessidade de um processo de descolonização: "entender a situação colonial não como algo passado e superado, mas sua persistente e eficaz refuncionalização através do tempo histórico e sua atualização permanente nos poderes estatais constituídos, mas também nas chamadas esferas civis e nos âmbitos privados" (2010: 110, tradução minha). .

${ }^{14}$ Cabe notar que paralelamente ao processo de politização da identidade indígena na Bolívia, há um processo de ressignificação de identidades locais, como a construção da "nação guarani", a partir de povos guaranis e chanés, na região do Chaco, ou ainda, processos de "etnogênese", como aquele que resultou da reivindicação de uma identidade yampara distinta da qhara qhara, no Altiplano.
} 
responsabilidades que cabem às famílias, participação em festas etc. Este é o caso, por exemplo, de uma parte da população da cidade de El Alto, que cresceu na periferia de $\mathrm{La} \mathrm{Paz}^{15}$.

\section{$O$ contexto internacional}

O processo mais recente de articulação e fortalecimento de organizações indígenas na Bolívia ocorreu dentro de um cenário internacional relativamente mais aberto a determinadas reivindicações dos povos indígenas. Na literatura acadêmica, esse ambiente internacional favorável é descrito a partir dos seguintes fatores: o fortalecimento do movimento indígena transnacional (cf. Ordóñez Cienfuentes, 2007; Urquidi et al., 2008); a participação de organizações não governamentais internacionais e de organismos multilaterais financiando organizações indígenas e projetos governamentais (cf. Ströbele-Gregor, 1994; Gross, 1999; Canessa, 2006; Albó, 2009; Healey, 2009); a crise do estado-nação (cf. Regalsky, 2006; Tapia, 2007a; Urquidi, 2007; Vega Camacho, 2007); e, a elaboração de acordos e tratados internacionais que reconhecem direitos aos povos indígenas (cf. Urquidi et al., 2008; Freitas, 2012).

Dentro do processo de construção de um movimento indígena transnacional no continente americano, destacam-se as reuniões realizadas em Barbados, na década de 1970, com a presença de antropólogos e indígenas de diferentes países (Ordóñez Cienfuentes, 2007).

Christian Gross (1999), em um artigo cujo subtítulo promete "algumas reflexões sobre a construção de uma nova fronteira étnica na América Latina", afirma que desde o

\footnotetext{
${ }^{15}$ Esse fato ficou evidente quando o governo El Alto fez uma campanha, durante a realização do último censo, para que seus moradores se cadastrassem nessa cidade e não em suas comunidades. Tal preocupação se deve ao fato da distribuição da renda aos municípios, pelo governo nacional, ser feita em função do número de habitantes.
} 
primeiro encontro de Barbados, assistimos ao "despertar indígena" (expressão cunhada por Michel de Certeau). Suas hipóteses para esse "renascimento" são as seguintes: o intenso processo de modernização vivido a partir da segunda metade do século XX teria provocado, "no caso da população camponesa e indígena, uma crise nos modelos tradicionais de controle econômico, ideológico, social e político que mantinham numerosos grupos subjugados"; uma crise do projeto de integração e modernização, iniciada na década de 1970 e que se agrava na seguinte; e, "o peso [...] do sistema internacional que sofrerá grandes modificações depois da descolonização e com o término da guerra fria” (ibid.: 2-4). A respeito da "verdadeira „,internacionalização da questão indígena", Gross sublinha uma mudança na retórica internacional, a partir da qual a destruição das florestas torna-se um problema mundial e não mais apenas nacional. $\mathrm{O}$ autor aponta igualmente o desenvolvimento de um novo direito positivo internacional na Organização Internacional do Trabalho (OIT) e a elaboração de programas de desenvolvimento financiados pelo Banco Mundial, pela Comunidade Europeia, pelo PNUD etc. que visam favorecer as populações indígenas (ibid.: 6). Gross ressalta, então, o caráter contraditório da globalização: "por um lado, essa afeta fortemente as comunidades indígenas, aumenta a sua crise e as obriga a reagir e a se defenderem e, por outro, proporciona todo tipo de novas ferramentas, de recursos que podem ser aproveitados por elas e suas organizações" (ibid.: 6, tradução minha).

Durante o trabalho de campo, pude observar a forte presença na Bolívia de organizações não governamentais e de organismos de cooperação bilateral ou multinacional. Esses atores internacionais financiam vários projetos em comunidades indígenas, interferem na elaboração de leis nacionais e bancam parte importante dos trabalhos realizados por diferentes ministérios e instituições governamentais. Igualmente, parte fundamental do financiamento de organizações indígenas bolivianas 
tem como origem essas organizações internacionais. Por conseguinte, um ambiente internacional que legitime um discurso sobre o indígena pode ser bastante favorável às organizações e comunidades. Contudo, algumas vezes, esse financiamento busca responder a expectativas externas que não necessariamente coincidem com aquelas das organizações ou das comunidades, tendo como resultado o financiamento de programas ou obras que não atendem à necessidade da população local, podendo, em alguns casos, ser prejudiciais. Ao mesmo tempo, é possível que as organizações indígenas, em função da dependência de financiamento, adaptem seus discursos àqueles considerados legítimos pelos atores externos.

Como vimos, a relevância do movimento indígena transnacional e da atuação de agências de cooperação bilaterais ou multilaterais podem indicar uma influência externa na formação de agendas das organizações indígenas bolivianas. Entretanto, como indica a noção de "efeito bumerangue" das "redes de advocacy", de que nos falam Keck e Sikkink (1999), as reivindicações podem nascer dentro do país, buscar apoio no cenário internacional para, em seguida, voltar ao debate nacional com maior legitimidade.

Apontando a importância de normas internacionais sobre os direitos indígenas, Caroline Freitas explica a elaboração de discursos sobre autonomias indígenas a partir de uma organização boliviana, o Consejo Nacional de Ayllus y Markas del Qullasuyu (Conamaq), e "suas interpenetrações e aproximações com o discurso da normativa estatal boliviana e da normativa do direito internacional sobre os direitos humanos que permitem de alguma maneira a sua legitimação na esfera pública” (2012: 32). Para tanto, a autora parte das noções de "modernidade entrelaçada", de Stuart Hall, e de "cascata de eventos", de Arjun Appadurai, "a fim de analisar o caso boliviano como fruto de processos que são, simultaneamente, locais e globais" (ibid.: 40). 
Frequentemente, lideranças indígenas bolivianas fazem referência à Convenção 169 da Organização Internacional do Trabalho, sobre povos indígenas e tribais em países independentes e à Declaração das Nações Unidas sobre os Direitos dos Povos Indígenas. A primeira, aprovada em 1989, foi assinada pelo governo boliviano depois de uma grande mobilização indígena no país, em 1990, conhecida como a "Marcha pelo Território e a Dignidade". Já a Declaração da ONU foi aprovada em 2007 e, imediatamente, assinada pelo governo de Evo Morales. Ela reconhece, pela primeira vez, o direito à autonomia e ao autogoverno. Segundo Freitas, a diferença entre a Declaração da ONU e outros documentos entendidos como instrumentos de defesa dos direitos humanos residiria no fato de que nesta, “os sujeitos desses direitos não são somente os indivíduos que compõem as comunidades indígenas, mas a própria coletividade, o grupo indígena como um todo, ou seja, os povos indígenas enquanto sociedades, culturas e comunidades vivas” (2012: 161). A aprovação do documento em meio ao debate em torno da elaboração do novo texto constitucional boliviano serviu como um elemento legitimador da demanda de autonomia indígena apresentada por algumas organizações sociais durante a Assembleia Constituinte (Garcés, 2010: 87).

Ordóñez Cienfuentes aponta a existência de importantes reuniões do movimento indígena continental durante as décadas de 1970 e 1980, nas quais a questão autonômica foi tratada: o $1^{\text {o }}$ Parlamento Índio da América do Sul, em 1974; o $1^{\circ}$ Congresso Internacional Indígena da América Central, em 1977; o $1^{\circ}$ Congresso dos Movimentos Índios da América do Sul, em 1980; a $1^{\circ}$ Assembleia do Congresso de Organizações Indígenas da América Central e Panamá, em 1988, são alguns dos exemplos apresentados pelo autor, além, das reuniões do parlamento indígena da América Latina (2007: 65-66). Segundo Héctor Díaz-Polanco, no entanto, a demanda de autonomia das organizações indígenas aparece na década de 1980 “como nunca antes” (2006 [1991]: 
118). Para o autor, a experiência de autonomia dos povos indígenas na costa atlântica da Nicarágua, reconhecida pelo governo revolucionário sandinista, explica em parte o renovado interesse sobre a questão autonômica indígena. Contudo, para Díaz-Polanco, a sua principal causa seria interna, efeito da nacionalização das lutas indígenas (ibid.: 119).

Sem dúvida houve uma clara nacionalização dos movimentos indígenas bolivianos nas últimas décadas, que fortaleceu diferentes demandas dos povos indígenas. Entretanto, no caso boliviano, assim como no caso dos indígenas da Nicarágua, o que possibilitou que o direito à autonomia desses povos e nações fosse reconhecido, foi a existência de um contexto de grave crise política.

Urquidi et al. explicam a politização recente das questões étnicas a partir da confluência de pelo menos três aspectos: o desenvolvimento do direito internacional; "a emergência de movimentos indígenas que atuam, nacional e internacionalmente, cada vez mais como grupos de interesse dentro da sociedade civil e nos espaços públicos democráticos pressionando por uma nova leva de leis de direitos coletivos"; e o reconhecimento do caráter multiétnico das sociedades presente em diferentes reformas constitucionais (2008: 201). No entanto, as autoras indicam que "apesar dos três aspectos estarem correlacionados, a conjuntura interna de cada país em relação à população indígena e o modo como se articula a esfera pública de direitos são fatores que fizeram predominar um aspecto sobre os outros" (ibid.: 201). Urquidi et al. citam Rodolfo Stavenhagen, relator especial da ONU para os direitos humanos e liberdades fundamentais dos indígenas, quando esse aponta a brecha existente entre as legislações nacionais de países que assinaram os acordos internacionais sobre os direitos indígenas e os princípios e normas neles presentes (ibid.: 214). Essa observação indica a 
importância de cenários nacionais favoráveis para a efetivação de direitos acordados em espaços internacionais.

Assim, os intercâmbios entre lideranças dos movimentos indígenas em fóruns internacionais; a existência de um contexto externo que legitime algumas reivindicações indígenas, seja por meio de financiamentos, seja através da elaboração de normas que reconheçam direitos pelos quais os movimentos indígenas lutam há décadas, e mesmo, séculos; e, a formação de redes de advocacy internacionais, como, por exemplo, as que estiveram presentes na Bolívia em diferentes debates no período da Assembleia Constituinte; todos esses fatores podem fortalecer as organizações indígenas e viabilizar suas demandas no cenário nacional. Entretanto, se tais reivindicações serão tomadas em conta pelos governos e na reestruturação de lógicas estatais depende das possibilidades ditadas pelo contexto interno.

Assim, sem negar a importância do cenário internacional, como o objetivo deste trabalho é entender as mudanças ocorridas nos últimos anos entre os povos e nações indígenas e o Estado boliviano, foco minha análise no contexto interno, pois, foram notadamente mudanças ocorridas dentro do cenário político do país que possibilitaram a inclusão de importantes direitos dos indígenas nas normas estatais bolivianas. São principalmente questões de ordem interna que explicam o fortalecimento do movimento indígena na Bolívia, quando comparado a outros países, e sua capacidade de tornar-se um importante ator da política nacional.

$\mathrm{Na}$ Bolívia, a possibilidade de reestruturação da ordem estatal para a participação dos indígenas e a inclusão de suas próprias formas de organização social e política dentro da estrutura estatal se deu a partir da mobilização de organizações indígenas e camponesas no cenário de grave crise política, iniciado em 2000. 


\section{O objetivo da pesquisa}

A vitória de Evo Morales, em 2005, a elaboração de uma nova constituição política, entre 2006 e 2008, assim como a eleição dos membros do Poder Legislativo, em 2005 e 2009, marcaram a inclusão de parte da população indígena boliviana no campo da política institucional nacional. Tal mudança foi resultado de uma grave crise política desencadeada a partir de uma forte mobilização social, entre os anos de 2000 e 2005, de setores que encontravam-se praticamente excluídos da política institucional do país. Essa mobilização de setores subalternos bolivianos, principalmente indígenas e camponeses, rompeu as fronteiras do campo da política institucional.

O objetivo deste trabalho é entender a dinâmica do processo político pelo qual as organizações indígenas e camponesas romperam com essas fronteiras, assim como as mudanças decorrentes desse processo nas relações entre o Estado boliviano e os povos indígenas e camponeses. Proponho ver em que medida esse campo foi alterado, permitindo, por um lado, a participação de atores indígenas que estavam articulados em organizações sociais até então excluídas do campo, e, por outro, possibilitando a inclusão dentro da esfera estatal de formas locais de organização política próprias dos povos indígenas, através das "autonomias indígena originário camponesas".

Analiso a participação dos indígenas no novo Estado a partir, principalmente, de quatro organizações que, no momento de sua fundação, reivindicavam a identidade indígena: a Confederación Sindical Única de Trabajadores Campesinos de Bolivia (CSUTCB), a Confederación de los Pueblos Indígenas de Bolivia (Cidob), o Consejo de Ayllus y Markas del Qullasuyu (Conamaq) e a Asamblea del Pueblo Guaraní (APG) ${ }^{16}$.

\footnotetext{
16 A CSUTCB, diferente das outras três organizações estudadas, formou-se reivindicando a dupla identidade de seus membros: camponesa e indígena. Apesar da ênfase na identidade indígena no
} 
O fato desta pesquisa partir da relação do Estado com organizações sociais que, no momento de sua fundação, assumem a identidade indígena, distancia-nos do debate sobre a pertinência dos dados estatístico sobre a população indígena.

A pertinência desta proposta deve-se ao fato dessas organizações indígenas e camponesas terem sido os principais atores organizados na mobilização popular que romperia com as fronteiras do campo e, igualmente, durante a sua redefinição.

\section{Crise política, mobilização popular e redefinição do campo da política institucional}

Na literatura acadêmica, encontramos explicações estruturais e conjunturais para o desencadeamento da crise política a partir de 2000. As primeiras detêm-se, sobretudo, na existência de um colonialismo interno na Bolívia, corroborando a interpretação de Silvia Rivera (1983) sobre a incapacidade da Revolução de 1952 em acabar com o padrão de organização social construído durante a colônia, apesar de seu discurso homogeneizante e pretensões antioligárquicas ${ }^{17}$. Rivera sublinha a existência do seguinte paradoxo: as tentativas de reformas políticas e econômicas e de modernização fortaleceram o padrão de dominação mestiça/criolla sobre o campesinato indígena (1990: 98). Partindo do conceito de "contradições diacrônicas", de Ernest Bloch, e inspirada na análise da sociologia histórica das transformações políticas, de Barrington Moore, a autora ressalta o impacto, nos conflitos presentes, de tensões não resolvidas

momento de sua formação e da importância que essa tomou em diferentes momentos da história da organização, atualmente, no cenário político boliviano, ela é mais identificada por sua identidade camponesa. Por essa razão, ao longo deste trabalho, refiro-me à CSUTCB como uma organização camponesa.

${ }^{17} \mathrm{O}$ debate sobre o conceito de colonialismo interno aparece com força na América Latina na década de 1960 a partir dos trabalhos de Pablo González Casanova e Rodolfo Stavenhagen. Em "Colonialismo Interno [Uma redefinición]”, González Casanova retoma os diferentes debates em torno do conceito. 
herdadas do passado. Haveria, dessa forma, uma coexistência do passado e do presente na sociedade boliviana (ibid.).

No prólogo da quarta edição de seu livro "Oprimidos pero no Vencidos", escrito em 2003, em meio à crise política, Rivera apontava uma crise da natureza da dominação estatal "com seus modelos clientelistas, patriarcais e coloniais de relação entre governantes e governados, entre elites e classes-etnias subalternas" e, conclui que, "em momentos como este, em que se torna explícita a confrontação entre „duas Bolívias „e, voltamos a escutar o eco das „duas repúblicas coloniais, e suas feridas ainda sangram, na memória e no corpo das classes-etnias oprimidas" (2003 [1984]: 13, tradução minha).

Em consonância com Rivera, muito autores apontam a manutenção das diferenças entre indígenas e não indígenas ao longo da vida republicana do país, como uma das causas da crise política iniciada na década passada (cf. Dunkerley, 2007; García Linera, 2008b; Hylton e Thomson, 2005; Prada, 2006; Tapia, 2007a). “A república boliviana se fundou deixando de pé os mecanismos coloniais que consagravam prestígio, propriedade e poder em função da cor da pele, do sobrenome, do idioma e da linhagem", afirma García Linera (2003a: 173, tradução minha). O autor sublinha a incapacidade da Revolução Nacional de 1952 em resolver a "herança colonial". Para ele, a criação do índio como uma construção identitária negativa do “Outro" e a etnificação da exploração são uma herança da época colonial que perduram (2008b: 138). A consequência seria a centralidade do "capital étnico" na organização social boliviana. Ou seja, a etnicidade na Bolívia se transformaria em um capital simbólico que influi na eficácia dos outros capitais (García Linera, 2007).

Raúl Prada explica que, com a Revolução de 1952 e a instituição do voto universal, os indígenas participariam do universo eleitoral, mas não do Estado, assim, a 
“crise do Estado nacional se expressa neste caso na síntese inconclusa do Estado. O Estado popular não alcança a síntese integral da sociedade [...]” (2006: 23, tradução minha).

Hylton e Thomson (2005) e García Linera (2008b) percebem, durante o ciclo de mobilização iniciado em 2000, uma reativação das lutas indígenas passadas. Os autores fazem referência ao que Silvia Rivera (2003 [1984]) chama de "memória longa" do movimento indígena. Rivera aponta a existência de dois "horizontes de memória coletiva" no momento indígena camponês. O primeiro seria esse da “memória longa das lutas anticoloniais do século XVIII, catalisada por um presente de discriminação e exclusão". Esse seria o elemento articulador do discurso do campesinato aymara do Altiplano, apesar de ser "permanentemente sintetizado e reforçado com a experiência, mais recente, do poder sindical do campesinato pós-52" (ibid.: 67, tradução minha). No caso do campesinato de Cochabamba, seria "o horizonte ideológico fundado na memória curta e na raiz cultural mestiça do movimento camponês, o que organiza e dá sentido a sua mobilização na década de 1970" (ibid.).

Assim como as memórias de Silvia Rivera, as razões encontradas na literatura para crise política estudada também fazem referência a dois tempos, ou dois momentos. Além da permanência do "colonialismo interno" apresentada acima, autores apontam causas para a crise relacionadas às estruturas políticas de "curta duração", referentes ao modelo neoliberal de configuração estatal (García Linera, 2008b). Para García Linera, a dupla dimensão da crise, de uma estrutura estatal de "longa duração" e outra de "curta duração", é o que diferencia essa crise estatal daquelas que se repetem de forma cíclica a cada quinze ou vinte anos (ibid.: 334). 
Silvia Rivera (1991), em um texto publicado quase uma década antes do último período de crise política, falava de uma crise dos paradigmas de "progresso" e "desenvolvimento" que teria possibilitado a discussão sobre o potencial de uma visão indígena para o futuro.

Os membros do Grupo Comuna ${ }^{18}$, Alvaro García Linera (2008b), Luis Tapia (2007a) e Raúl Prada (2006), apontam a associação entre causas de longa e curta duração. Prada (2006) acrescenta o que chama de "ciclo mediano" da crise, referindose a uma crise do modelo de acumulação estatal, que explicaria o fracasso do governo da Unidad Democrática y Popular (UDP) (1982-1984) na volta à democracia. Tapia (2007a) aponta a existência de uma crise de estado com várias facetas: uma crise fiscal, como o aumento do endividamento do país e o "fracasso" das privatizações; uma crise de representação, decorrente de anos de governos de partidos como o mesmo projeto econômico e que representavam a mesma fração da classe dominante; de legitimidade, com o aumento da corrupção e revoltas populares que demandam a refundação do Estado; e, por fim, uma crise de correspondência ligada ao caráter colonial do Estado.

Assim como os intelectuais do Grupo Comuna, outros autores apontam elementos "de curta duração" desencadeadores do novo ciclo de crise política na Bolívia. Dentre as explicações conjunturais encontradas na literatura está a crise dos partidos políticos e do modelo de aliança reeditado desde 1985, com a diminuição da sua legitimidade aos olhos de parte importante da população boliviana (cf. Calderón e Gamarra, 2004; Chávez e Mokrani, 2007; Mamani, 2007; Mayorga, 2009) ${ }^{19}$. Fernando

\footnotetext{
${ }^{18}$ O Grupo Comuna foi um importante centro de produção intelectual sobre a política boliviana no final da década de 1990, início da década seguinte, dele fazem parte Alvaro García Linera, Luis Tapia, Oscar Vega Camacho e Raquel Gutiérrez.

19 García Linera ressalta que os partidos políticos nunca conseguiram se converter em veículos de canalização das demandas da sociedade (2008b: 338).
} 
Mayorga, por exemplo, ressalta que a "crise da democracia pactuada" estaria relacionada à desarticulação do princípio hegemônico que ordenou a prática e o discurso dos partidos relevantes, formado pela democracia representativa e pelo liberalismo econômico. Dentre as consequências dessa desarticulação estariam as "mudanças na discursividade política que se traduziram na emergência de atores contestatários" e "na formulação de propostas contrárias ao neoliberalismo" (2009: 130, tradução minha).

Dentre os elementos explicativos de "curta duração", encontramos também fatores econômicos. Vivian Urquidi, em seu estudo sobre o movimento cocaleiro na Bolívia, sublinha a importância da crise desencadeada nos anos 1980, para entendermos o camponês plantador de coca naquele país, pois, a crise "redefiniu diversos aspectos importantes da vida política e econômica da Bolívia" (2007: 142). Urquidi explica que uma das consequências das políticas neoliberais foi a explosão da miséria no campo e nas cidades (ibid.: 33). E, segundo a autora, os mais atingidos pela crise foram os responsáveis pelo surgimento de formas contemporâneas de mobilização social (ibid: 34). Já para Calderón e Gamarra, a política econômica adotada pelos diferentes governos durante o período de democracia pactuada foi "a base fundamental do consenso, pois se estabilizou a economia, o crescimento econômico e a inversão externa", dessa forma, as críticas a esse modelo político estariam relacionadas à recessão econômica vivida pelo país a partir de 1998 (2004: 12). Os autores assinalam um processo acelerado de deterioração da qualidade de vida, em parte explicado pela urbanização marginal e pelo "crescimento descontrolado da informalidade" (ibid.: 19).

Desde outra perspectiva, Andrew Mc Neish (2006) indica como as "reformas neoliberais" pioraram a distribuição de riqueza entre pobres e ricos, apesar da adoção de políticas de redução da pobreza ao longo da década de noventa. Para o autor, havia uma insatisfação da população com os termos do desenvolvimento. Frustrações teriam sido 
geradas em função da contradição entre a retórica sobre a participação popular presente nas "políticas neoliberais de segunda geração" - e a participação real na elaboração de políticas públicas. Nesse desencontro estariam as raízes dos confrontos de 2003.

Diferentemente das análises sobre causas apontadas acima, adoto aqui a perspectiva de Michel Dobry (1992 [1986]), que propõe uma abordagem dos processos críticos a partir de sua dinâmica, das jogadas dos atores durante a crise ${ }^{20}$. Segundo o autor, quando nos concentramos nas causas e consequências das crises, negligenciamos o que é fundamental para sua compreensão, a dinâmica das lutas entre os atores, da disputa entre as forças políticas em presença. Haveria, ademais, uma possível autonomia entre causas e processos de crise que certas análises não levariam em conta. Dobry não questiona, todavia, a validade de todas as análises das causas das crises, mas sim o pressuposto de que seria possível entender esses momentos sem ter em conta do que eles são feitos.

A partir análise de Dobry, é possível atentar para a fluidez do sistema social em momentos críticos. Dobry trata de sistemas sociais complexos, caracterizados pela autonomia relativa de seus setores - conceito próximo ao de campo de Pierre Bourdieu. Esses setores têm lógicas sociais específicas, formadas por temporalidades, culturas locais e questões (enjeux) específicas. Em tempos de crise, porém, essa configuração mudaria. A fluidez das estruturas sociais nesses momentos é caracterizada por uma redução da autonomia dos setores, e pelo fato dos cálculos realizados pelos atores presentes em cada setor deixarem de seguir principalmente suas lógicas setoriais. As grandes crises políticas corresponderiam, assim, a mobilizações multisetoriais.

\footnotetext{
${ }^{20}$ Dobry explica ter tomado emprestado a noção de jogada (coup, em francês) da Interação estratégica de Thomas Schelling (Dobry, 1992 [1986] : 22).
} 
A fluidez do sistema social nos momentos de crise, formulada teoricamente por Dobry, parece ter sido percebida por Zavaleta Mercado (1983), quando este aponta que a união entre as classes camponesa e operária era possível apenas durante uma grave crise política, que geraria um tempo comum e a possibilidade de criar uma intersubjetividade, ou seja, uma lógica comum a grupos que teriam lógicas tão distintas em conjunturas ordinárias. Para Zavaleta Mercado, importante sociólogo boliviano com quem dialoga a maioria dos autores bolivianos, as graves crises políticas seriam situações privilegiadas para o conhecimento da sociedade boliviana, em função da sua formação social abigarrada (heterogênea, bagunçada). Tal adjetivo faz referência à sobreposição de "duas épocas econômicas sem se combinarem muito, como se o feudalismo pertencesse a uma cultura e o capitalismo a outra e ocorressem, no entanto, no mesmo cenário ou como se houvesse um país no feudalismo e outro no capitalismo" (ibid.: 17, tradução minha). O conceito de "formação social abigarrada" faz referência ao processo desigual de desenvolvimento do capitalismo na Bolívia, que não foi capaz de produzir em todo o território nacional "um processo de acumulação originária, no sentido de concentração da terra, concentração dos meios de produção e destruição de estruturas sociais e formas de vida preexistentes" (Tapia, 2010: 100, tradução minha).

Igualmente, a análise da crise aqui apresentada foi fortemente influenciada pelo estudo sobre crise política de Brasilio Sallum Jr. (1994). Adoto do autor uma abordagem da conjuntura crítica a partir de mudanças de médio prazo nas estruturas estatais e sociais. Estudar a dinâmica interna da crise política é fundamental, como defende Dobry, contudo, se nos interessamos por seus resultados, como é o caso desta pesquisa, é imprescindível ter em conta as transformações políticas, sociais e econômicas dentro das quais a crise se insere. 
Assim como Zavaleta Mercado (1983) o faz para o caso boliviano, Sallum Jr. analisa a transição do regime autoritário no Brasil e o despertar da democracia. Nos dois países, as ditaduras militares haviam sido instauradas em 1964 e o processo de transição política ocorreu no final da década de 1970 e início da seguinte. A partir da comparação com o caso brasileiro apresentado por Sallum Jr., foi possível atentar para algumas características da crise de transição para o regime democrático boliviano que influenciaram o mais recente ciclo de crise política vivido pela Bolívia. Primeiro, assim como no Brasil haveria uma crise do Estado desenvolvimentista que antecede e supera a crise do regime, no caso boliviano, a crise do Estado de 52 se manteria vigente mesmo depois da volta formal à democracia.

Neste sentido, concordo com Vega Camacho (2010), quando esse aponta que a crise do Estado boliviano iniciada na década de 1970 se tornaria evidente a partir das mobilizações sociais iniciadas em 2000. Trata-se de uma crise na forma de articulação entre o Estado e a população rural indígena, criada com a Revolução de 52.

Como mencionei anteriormente, após a Revolução, o campesinato indígena devia articular-se com o Estado através de sindicatos controlados por esse. A partir dos anos 70 , esse setor social começa a se reorganizar através de uma estrutura sindical independente do controle estatal, movimento que foi seguido por uma organização supraétnica dos indígenas das Terras Baixas. Por outro lado, esse movimento coincidiu com uma grave crise econômica, cuja solução adotada pelos governos a partir de 1985 implicou na desarticulação da organização econômica criada em 1952, na qual o Estado tinha o papel preponderante, através do controle das empresas responsáveis pelos principais setores econômicos do país.

O ciclo de mobilizações populares iniciado em 2000 tornaria fluidas as fronteiras do campo da política institucional boliviana. Se as comunidades, ruas e 
estradas do país eram o espaço privilegiado para a participação política dos setores subalternos; a partir de 2006, representantes dos movimentos indígenas e camponeses, atores centrais deste estudo, passaram a ocupar lugar de destaque na construção de um “novo Estado boliviano". Ao mesmo tempo, a partir do governo de Evo Morales, o Estado passa a ocupar um papel de maior protagonismo na economia, com a nacionalização de empresas de setores estratégicos.

A eleição de Evo Morales à Presidência da Bolívia, em dezembro de 2005, foi precedida por esse ciclo de mobilizações populares iniciado com a "guerra da água" e as mobilizações do campesinato no Altiplano de La Paz. A primeira fase da crise política chegaria ao fim com a queda do presidente Carlos Mesa, em 2005. Embora a instabilidade política persista após 2006, quando o Movimiento al Socialismo (MAS), partido de Evo Morales, assume o controle do governo nacional; a crise política entra em uma nova fase. São as características distintas dos dois períodos desse processo de crise política que nos permitem identificar duas fases dentro do mesmo ciclo crítico.

Neste trabalho, as organizações indígenas e camponesas são os principais atores. Partir dessas organizações para entender o que muda na Bolívia após 2006 se justifica, pois, quero entender em que medida o campo da política institucional se expande, a partir da crise política, para incluir atores que até então "faziam política", principalmente, a partir da participação em outros espaços. Deter-me-ei brevemente nessa divisão entre campos adotada.

\section{Como explica Pierre Bourdieu:}

Com exceção das sociedades menos diferenciadas (que ainda assim apresentam diferenças, mais difíceis de medir, de acordo com o capital simbólico), todas as sociedades se apresentam como espaços sociais, isto é, estruturas de diferenças que não podemos compreender verdadeiramente a não ser construindo o princípio gerador que funda essas diferenças na objetividade. Princípio que é o da estrutura da distribuição de 
formas de poder ou dos tipos de capital eficientes no universo social considerado - e que variam, portanto, de acordo com os lugares e os momentos (2013 [1994]: 50).

O campo, para Bourdieu, deve ser entendido como "campo de força", "cuja necessidade se impõe aos agentes que neles se encontram envolvidos" e "campo de lutas", "no interior do qual os agentes se enfrentam, com meios e fins diferenciados conforme sua posição na estrutura do campo de forças" (ibid.: 50).

Com efeito, não apenas as estruturas dos campos se transformam internamente, como também a separação entre diferentes campos varia em cada sociedade e, dentro dessas, ao longo do tempo, em função do grau de autonomização de cada campo. Essa autonomia implica na existência de linguagens, temporalidades, rotinas e procedimentos específicos $^{21}$. Em função dessas características, é possível apontar, no caso boliviano, a autonomização do campo da política institucional.

Quando falo de "campo da política institucional", refiro-me ao campo de atividades políticas que concernem o Estado, partindo do princípio de que há um espaço de atividades políticas no qual atuam os atores que não se restringe à política institucional relacionada às tarefas estatais ${ }^{22}$. Esse é o caso dos sindicatos e dos movimentos sociais na Bolívia e na maioria das democracias. Contudo, ao analisarmos a Bolívia, é preciso ter igualmente em mente a existência de autonomias de facto em diferentes regiões do território do boliviano. Trata-se de formas de organização política que foram sendo construídas paralelamente ao Estado, sem correspondência com as

\footnotetext{
${ }^{21}$ Essas características não excluem a possibilidade de uma determinada porosidade das fronteiras dos setores nem a existência de atores multiposicionados.

${ }^{22}$ A percepção aqui apresentada do espaço da política na Bolívia e a autonomização do que chamamos de "campo da política institucional" deriva do estudo específico desse país, bem como da análise do funcionamento do "campo da política exterior", dentro do campo da política estadunidense, em Pannain (2008) e do debate sobre a autonomização do campo dos movimentos sociais na França, em Péchu (2001) e Mathieu (2004).
} 
normas estatais ou com as divisões político administrativas em municípios, províncias e departamentos.

A elaboração do conceito de "campos de ação estratégica" de Doug McAdam e Neil Fligstein $(2011 ; 2012)$ nos ajuda a entender melhor a ideia da existência de um campo político boliviano, dentro do qual existem diferentes campos, dentre eles, o que chamo de "campo da política institucional". Os autores usam a imagem das bonecas russas tradicionais para explicar que os campos são compostos por outros campos.

Segundo Tapia, uma das características do abigarramientoda sociedade boliviana apontado por Zavaleta Mercadoseria é a persistência de "estruturas de autoridade ou de governo de vários povos e culturas que foram conquistadas" (ibid.: 101). Tendo isso em vista, não seria possível falar em monopólio da política, afirma o autor (ibid.). A existência de estruturas de poder patrimonial seria a outra dimensão desse abigarramiento $^{23}$.

Neste estudo, abordarei as formas de "fazer política" dos povos e nações indígenas bolivianos que estão fora da esfera estatal, e do campo da política institucionalizada pelo Estado. Essas formas autônomas se dão em diferentes níveis: a partir do controle político, social e econômico de algumas comunidades por meio de autoridades locais, eleitas a partir de formas próprias e que governam através do direito consuetudinário; a partir da formação de estruturas locais, como sindicatos e organizações indígenas, que detém igualmente um poder político sobre determinadas áreas; e, finalmente, por meio de estruturas regionais e nacionais, que articulam diferentes "povos e nações indígena originário camponeses" e são seus interlocutores com o Estado.

\footnotetext{
${ }^{23}$ Essa estrutura patrimonialista teria sido desorganizada nas regiões dos Vales e do Altiplano, após a Revolução de 1952, mas se manteria em outras regiões (Tapia, 2010: 112).
} 
Apesar de, em diferentes lugares na Bolívia, as regras vigentes para a resolução de conflitos, para a organização econômica e para a eleição de autoridades serem diferentes daquelas do Estado boliviano, isso não implica em uma total ausência do Estado desses territórios, como explica Tapia:

\begin{abstract}
A existência dessas estruturas de autoridade não significa que nestes territórios nunca haja presença do estado boliviano, mas que quando o faz, o que em geral costuma ser de forma descontínua no tempo, aparece como uma estrutura paralela e sobreposta, com caráter mais ou menos colonial, na medida em que operado para extrair trabalho, subordinar, dominar e muito ocasionalmente para integrar e democratizar as relações internas ou sua articulação com o resto do país (2010: 103, tradução minha).
\end{abstract}

Tapia destaca que a paulatina expansão do capitalismo, ao longo dos séculos XIX e XX, desorganizou núcleos comunitários e reduziu a diversidade cultural, operando "com mais força que a organização de uma estrutura estatal em base a princípios mais universais" (ibid.: 104, tradução minha).

Ao longo deste trabalho veremos que a presença estatal se deu forma diversa e com desigual intensidade e efetividade em diferentes regiões do território boliviano. Com efeito, o grau de autonomia em relação ao Estado varia bastante, sendo que em muitas comunidades convivem formas de organização comunal ao lado de formas de organização republicanas.

\title{
A criação do Estado Plurinacional da Bolívia e as autonomias indígenas
}

A partir da promulgação da nova Constituição em 2009, a Bolívia passou a ser um Estado plurinacional, reconhecendo a existência de diferentes nações e povos indígenas dentro do território boliviano. Além da importância simbólica desse reconhecimento, suas consequências práticas são fundamentais, pois, implicam na 
superação de dois descompassos apontados por Tapia como uma das causas da crise política iniciada em 2000: de um lado, entre a diversidade cultural da população e os sujeitos governantes e, de outro, entre as instituições políticas estatais e a diversidade de matrizes culturais presentes no país (2007a: 49).

A superação desses descompassos implicava, como afirma Oscar Vega Camacho, na possibilidade de pensar "de outro modo a condição estatal", de "ensaiar uma imaginação política distinta, diferente, alternativa à ordem existente e herdada" (2010: 109). Essas transformações necessitavam, segundo o autor, uma descolonização do pensamento, das práticas, das instituições e da vida em sociedade (ibid.: 110).

Segundo Boaventura Sousa Santos, a plurinacionalidade é o reconhecimento de que a nação está inconclusa: “a polarização entre nação cívica e nação étnico-cultural é um ponto de partida, mas não necessariamente um ponto de chegada" (2013 [2010]: 92, tradução minha). Já Raúl Prada, intelectual boliviano que participou da redação do novo texto constitucional como representante do Movimiento al Socialismo (MAS), de Evo Morales, argumenta o seguinte sobre o Estado plurinacional:

O Estado já não é a síntese política da sociedade, também deixa de ser compreensível a separação entre Estado, sociedade política e sociedade civil, pois, o âmbito de funções que correspondem ao campo estatal é absorvido pelas práticas e formas de organização sociais. O Estado plurinacional se abre às múltiplas formas de exercício prático da política, feita por parte das "multidões". Falamos de um Estado plural institucional, que corresponde à condição multisocietal. Trata-se de mapas institucionais inscritos em múltiplos ordenamentos territoriais, pelo menos quatro: territorialidades indígenas, geografias locais, geografias regionais e cartografias nacionais. A emergência do plural e do múltiplo rasga o velho mapa institucional, não permite a expropriação institucional, nem a unificação do diverso, ou a homogeneidade da diferença; abre-se ao jogo da combinação de distintas formas de organização, ao jogo em rede e de tramas flexíveis (2010: 88, tradução minha). 
O Estado Plurinacional, por um lado, modificou instituições políticas estatais, a partir da inclusão de formas de organização política e social existentes, diferentes daquelas reconhecidas pelo Estado até então. Tal inclusão se deu, por exemplo, com o reconhecimento da jurisdição indígena originário camponesa em um mesmo nível hierárquico da jurisdição ordinária ${ }^{24}$, ou com a possibilidade de povos indígenas elegerem membros do Parlamento, agora batizado de Assembleia Legislativa Plurinacional, a partir de normas próprias. Por outro lado, o novo Estado reconhece aquelas formas de organizações políticas locais, que chamo de autonomias de facto, ao criar as "autonomias indígena originário camponesas". Nesse sentido, Boaventura Sousa Santos indica que a plurinacionalidade implica em uma heterogeneidade institucional do Estado, interna às instituições, "onde estejam presentes diferentes modos de pertencimento institucional em função dos direitos coletivos", e externa, "sempre que a dualidade institucional paralela e/ou simétrica seja a via para garantir o reconhecimento das diferenças" (2013: 92-3, tradução minha).

Assim, a relação entre os indígenas, a partir de suas próprias formas de organização social e política, e o Estado boliviano poderia ser analisada por diversos prismas. Poderia, por exemplo, tomar em conta a inclusão nas políticas de saúde pública de práticas autóctones, ou estudar o funcionamento do Tribunal Constitucional Plurinacional, conformado por representantes do sistema ordinário e do sistema indígena originário camponês. Neste trabalho, contudo, estudo as mudanças na relação entre indígenas e o Estado acompanhando o reconhecimento de governos autônomos locais, uma demanda central das organizações indígenas durante o processo de redação do novo texto constitucional, entre 2006 e 2008.

\footnotetext{
${ }^{24}$ Constituição Política art. 179, II.
} 


\section{A construção da pesquisa}

Em fevereiro de 2009, eu chegava à Bolívia pela primeira vez. Em uma curta viagem de turismo, chamou-me a atenção a quantidade de muros pintados, em La Paz e El Alto, com palavras de ordem em defesa do "processo de mudança" e de Evo Morales e a favor da aprovação da nova Constituição Política.

No ano seguinte voltei à Bolívia para trabalhar como voluntária em uma organização na periferia de Cochabamba e em um instituto de pesquisa. Ainda que esta estadia tenha sido curta, a minha rotina possibilitou inúmeras descobertas sobre o país e seu contexto político. Impressionava-me o entusiasmo com que as pessoas conversavam sobre política. Assim como em La Paz e El Alto, em Cochabamba e Chuquisaca, os muros falavam. E falavam de política! Eu cheguei à Bolívia em janeiro de 2010, um mês após as eleições nas quais Evo Morales e Álvaro García Linera haviam sido reeleitos com $64,22 \%$ dos votos e a maioria das cadeiras das duas casas da Assembleia Legislativa Plurinacional haviam sido alcançadas pelo Movimiento al Socialismo $(\mathrm{MAS})^{25}$.

Viajando pelo interior do departamento de Cochabamba, vi muitos muros pintados em azul e branco, com a sigla do partido vencedor. Antes, esses muros eram pintados com a sigla do Movimiento Nacionalista Revolucionario (MNR), fui avisada. Ainda pude ver em um muro do centro urbano do município de Tarabuco, no departamento de Chuquisaca, uma antiga pintura descascada da campanha de 2002, de Sanchéz de Lozada.

\footnotetext{
${ }^{25}$ Fonte: Vicepresidencia del Estado Plurinacional de Bolivia. Disponível em: http://www.vicepresidencia.gob.bo/IMG/pdf/ciclo_resultados.pdf, consultado em 02/06/2013.
} 
Quase três anos depois da minha segunda viagem, iniciei meu trabalho de campo na Bolívia, em setembro de $2012^{26}$. O contexto político, ou a conjuntura política, como se diz na Bolívia, era outra. O que me chamou mais a atenção no trabalho de campo foram os importantes conflitos entre o governo de Evo Morales e grupos da sociedade civil boliviana e os conflitos no interior desses. Ao mesmo tempo, pude perceber um movimento, por parte do governo central, de afirmação da sua legitimidade e de tentativa de construção de uma nova hegemonia. Era evidente que a tensão entre o governo e as organizações indígenas, Cidob e Conamaq, haviam aumentado desde as últimas eleições em 2010.

Foi nesse novo contexto de estabilização insitutcional que realizei meu trabalho de campo, entre 2012 e 2013, fundamental para a elaboração desta pesquisa. Durante o período de aproximadamente um ano em que vivi na Bolívia, entrevistei 33 atores, dentre eles, representantes das organizações indígenas e assessores, representantes do Ministério de Autonomias, intelectuais, membros da cooperação nacional e internacional que trabalham com os municípios em conversão à autonomia indígena e autoridades desses municípios $^{27}$. Alguns desses atores foram escolhidos por trabalharem direta ou indiretamente com a construção de processos indígenas autonômicos na Bolívia. Outras entrevistas permitiram uma melhor compreensão do processo político recente que busco reconstruir neste trabalho, a partir da relação entre o Estado e os povos indígenas bolivianos.

\footnotetext{
${ }^{26}$ Eu havia viajado para Bolívia em 2011, para iniciar o campo. No entanto, por motivos de saúde, tive que voltar ao Brasil poucos dias depois de chegar ao país.

${ }^{27}$ É preciso ter em conta que muitos desses atores estão "multiposicionados": intelectuais que já participaram do governo ou atuaram como assessores de organizações indígenas; representantes indígenas que trabalham para organizações não governamentais ou que já exerceram cargos de governo local. Algumas vezes os atores ocupam posições que atualmente se encontram em conflito com suas antigas organizações. Por esta razão, e dada a grande polarização do cenário político boliviano, em alguns casos optei pelo anonimato em determinadas citações de entrevistas ao longo desse trabalho.
} 
As informações coletadas no trabalho de campo, contudo, não se resumem àquelas fornecidas por esses entrevistados. Apesar de muitos atores se recusarem, não necessariamente de forma explícita ${ }^{28}$, a serem entrevistados, eles se mostravam dispostos a compartilhar informações importantes em conversas pessoais, em eventos sobre o tema da autonomia indígena, ou em situações informais, como enquanto compartilhávamos uma refeição. Posso dizer que aprendi tanto nessas conversas quanto nas entrevistas.

Viver por muitos meses na Bolívia me possibilitou igualmente participar de diferentes eventos organizados pelo governo boliviano em La Paz. Nesses eventos, sendo um deles fechado para o público, pude acompanhar uma das facetas da construção da nova estrutura estatal.

Ao longo de 2013, realizei três viagens para Charagua, acompanhando a divulgação do estatuto autonômico desse município em conversão à autonomia indígena. Nessas viagens, participei de eventos realizados em cinco comunidades guaranis. Em duas, acompanhei um representante do Centro de Investigación y Promoción del Campesinato (Cipca) e membros da assembleia autonômica responsável pela redação do estatuto e, na terceira, fui com um desses representantes. Oito entrevistas formais foram realizadas em Charagua. Mas, mais uma vez, as conversas informais com representantes da assembleia, autoridades locais e membros das comunidades locais foram fundamentais ${ }^{29}$. Conhecer algumas comunidades guaranis foi igualmente importante para entender a presença/ausência do Estado boliviano em seu território e como vive essa parte da população boliviana que está tão longe dos grandes

\footnotetext{
${ }^{28}$ Diferentes atores desmarcaram e remarcaram entrevistas comigo várias vezes, para não se recusarem de forma explícita a serem entrevistados.

${ }^{29} \mathrm{Em}$ uma dessas conversas, meu interlocutor me explicava que as pessoas tinham que me conhecer melhor para ter confiança para serem entrevistadas. Ele me aconselhava que eu ficasse algum tempo em Charagua. De fato, talvez porque ele tivesse razão, talvez porque eu me sentisse progressivamente mais à vontade, a maioria das entrevistas gravadas foi realizada apenas na terceira viagem que fiz ao município.
} 
centros de poder econômico e político do país, embora de seu subsolo saia um componente importante da riqueza nacional, os hidrocarbonetos.

Charagua é o maior município da Bolívia, com $74.424 \mathrm{~km}^{2}$, e conta com mais de cem comunidades guaranis. Os dias que tomávamos para cruzar esse imenso território e as inúmeras horas dentro de um veículo tornaram meus companheiros de viagem importantes interlocutores, com quem aprendi muito sobre os guaranis, a história do município e seu processo de construção da autonomia. Nos dias que passei no povoado central do município, "Charagua Pueblo", pude entrevistar autoridades guaranis e entender um pouco melhor a dinâmica local e a percepção da população urbana sobre o processo de conversão à autonomia indígena.

Charagua foi escolhida para a realização de parte do trabalho de campo por duas razões principais: primeiro, porque os guaranis, através da Asamblea del Pueblo Guaraní (APG), haviam sido um dos principais promotores da autonomia indígena durante o processo constituinte; segundo, porque enquanto pesquisadora mulher eu fui aconselhada que seria mais facilmente recebida pelos guaranis ${ }^{30}$.

Além das viagens à Charagua, acompanhei pesquisadores do grupo "Pueblos originarios en lucha por las autonomías: Movimientos y políticas en América Latina", do Conselho Latino-americano de Ciências Sociais (Clacso), em uma reunião na cidade de Camiri com dezenas de representantes da APG. Ao longo de todo um dia, os

\footnotetext{
${ }^{30}$ Dentre os guaranis, muitas mulheres alcançaram nos últimos anos cargos de autoridade. Nas Terras Altas, embora se evoque o princípio de equilíbrio entre homens e mulheres, o "chacha-warmi", e os cargos de autoridades sejam ocupados, em geral, por casais, as mulheres ocupam papel secundário na política. Essa observação foi corroborada durante uma entrevista realizada com uma Mama Tªlla (autoridade feminina) do Conamaq, quando ela resolveu interromper a entrevista com o argumento de que ela não falava de política. De fato, antes de iniciar a pesquisa em Charagua havia tentando organizar uma viagem para outro município do Altiplano em conversão à autonomia indígena e logo percebi que se tratava de uma tarefa pouco viável se eu não tivesse algum pesquisador para me "apresentar".

Cabe aqui uma observação importante sobre a questão de ser uma mulher realizando o trabalho de campo em espaços sociais extremamente machistas. Em diferentes momentos ao longo do trabalho de campo percebi que o fato de ser mulher não apenas dificultava o meu acesso a alguns lugares e espaços como, igualmente, colocava-me em situações constrangedoras e intimidantes. Assim, ter chegado pela primeira vez a Charagua com um contato seguro tornou a pesquisa muito menos difícil nesse sentido.
} 
representantes guaranis compartilharam conosco sua percepção do processo de conversão à autonomia de Charagua e em outros municípios da Bolívia, a relação entre a organização e o atual governo central e sua avaliação sobre o cenário político boliviano. Nessa viagem, tive igualmente a oportunidade para visitar uma comunidade guarani fora de Charagua, Pueblo Viejo.

Todos os meses em que vivi na Bolívia podem ser considerados como uma imersão no campo. Como explica Freitas, "tudo pode ser dado de pesquisa, tudo isso, toda a vivência desse universo distinto e novo, por mais que não esteja diretamente relacionada com o objeto pesquisado, é formadora de nossa perspectiva sobre a realidade em estudo" (2012: 45). Frequentar os mercados de La Paz e El Alto, os eventos nas universidades, assistir a filmes nacionais, participar de marchas, ler diariamente os jornais locais, conversar com amigos bolivianos, as viagens realizadas a comunidades indígenas do Altiplano e Amazônia, todas as experiências vividas naqueles meses na Bolívia foram importantes para o meu entendimento desse país e de sua população. As informações e percepções foram descritas nos diferentes cadernos de campo que sempre me acompanhavam.

Para esta pesquisa foi realizada igualmente uma vasta revisão bibliográfica, principalmente centrada em autores que tratam da questão indígena na Bolívia e na América Latina e sua relação com o Estado. Foram consultados igualmente leis, documentos elaborados pelas organizações indígenas e pelo atual governo, principalmente referentes ao tema das autonomias indígenas. A consulta de periódicos disponíveis na internet também foi importante para a reconstituição de alguns eventos políticos. 


\section{Plano da tese}

Para apreendermos a transformação do "campo da política institucional" é preciso reconstruir esse campo antes do ciclo de mobilização social iniciado em 2000. O primeiro capítulo apresenta a criação do Estado de 52. O objetivo do capítulo é fornecer alguns elementos que definam o modelo estatal criado a partir de 52 e suas alterações ao longo das décadas seguintes. O foco será a relação entre indígenas e o Estado. Em seguida, apresento a configuração do campo da política institucional boliviana a partir da democratização; aponto o lugar ocupado pela população indígena e suas organizações na sociedade e na política; e, as mudanças políticas, sociais e econômicas que levaram à crise política a partir de 2000.

No capítulo 2, partindo da proposta de Michel Dobry (1992 [1986]), reconstituirei a dinâmica da crise política que possibilitou as mudanças em questão. Terei em conta as jogadas dos atores, sejam eles indivíduos de central importância, como lideranças dos movimentos sociais, ou as próprias organizações sociais. $\mathrm{Ou}$, como ocorreu em 2003, a atuação organizada, mas sem uma liderança centralizada, da população da cidade de El Alto. Esse capítulo começa com as mobilizações ocorridas em Cochabamba, no episódio conhecido como "guerra da água", e sua articulação com um levante organizado no Altiplano do departamento de La Paz, liderado pela Confederación Sindical Única de Trabajadores Campesinos de Bolivia (CSUTCB). Em seguida, analisarei a atuação do importante movimento camponês dos produtores de folha de coca e a organização da Marcha Indígena pela Assembleia Constituinte, em 2002. As mobilizações populares atingiriam um novo patamar nos eventos descritos ocorridos em 2003 que tiveram como consequência a fuga do então presidente boliviano Gonzalo Sanchéz de Lozada. Veremos que a crise política não chegaria ao fim com a posse do vice de Lozada, Carlos Mesa, que não completaria o mandato. Finalmente, 
abordarei as formas de organização política paralelas à ordem estatal, que foram importantes durante as mobilizações sociais iniciadas em 2000.

O processo de sucessão de Mesa romperia a ordem institucional e anteciparia as eleições presidenciais e parlamentarias. Evo Morales, representante do movimento cocaleiro, seria eleito presidente e seu partido, o Movimiento al Socialismo Instrumento Político por la Soberanía de los Pueblos (MAS-IPSP), elegeria a maior bancada da câmara baixa.

No Capítulo 3, acompanharemos o funcionamento da Assembleia Constituinte, bandeira importante das mobilizações sociais entre 2000 e 2005. A eleição para seus membros foi convocada nos primeiros meses do governo de Evo Morales. Analisarei o processo constituinte através dos debates em torno da inclusão do direito à autonomia indígena e as confrontações ocorridas dentro e fora da Assembleia Constituinte que apontam a perpetuação da crise política. Ao acompanhar o processo de inclusão da autonomia indígena na Constituição, durante a edição do texto constitucional negociada com a oposição, e as negociações subsequentes entre organizações indígenas e o governo central para a implantação desses governos autônomos, indicarei em que medida o novo Estado está superando o descompasso entre as organizações políticas existentes em diversas comunidades e a ordem estatal.

No capítulo 4, apresentarei a reconfiguração do campo político após a crise, a partir da análise dos debates em torno da Lei Marco de Autonomia e Descentralização e a mobilização em torno do direito à consulta dos povos indígenas que levaram à realização de três marchas indígenas entre 2010 e 2012. Em seguida, apresentarei um processo de construção local do novo direito à autonomia, através das observações realizadas durante o trabalho de campo no município de Charagua. 


\section{Capítulo 1: Os indígenas e o Estado boliviano}

Bolivia había sido desde siempre un país de los señores y nadie ni en la izquierda ni en la derecha, como no fuera la plebe en su rabia más cerrada, pensaba que tal cosa pudiera cambiar en lo esencial. Esto es cierto: los pueblos miran a veces como su libertad a lo que suele no ser sino una disputa de remplazo entre estirpes de sus amos (Zavaleta Mercado, 1983: 50).

Nas décadas de 1930 e 1940, houve uma reconfiguração do campo partidário e a criação de novos sindicatos. Em 1932, foi fundado o trotskista Partido Obrero Revolucionário (POR), que exerceu um papel fundamental na articulação do movimento de trabalhadores mineiros. Em 1940, nasceu o Partido Izquierda Revolucionaria (PIR), de orientação stalinista. Dois anos mais tarde, foi criado o Movimiento Nacionalista Revolucionario (MNR), partido central da política boliviana nas seis décadas seguintes. A Federación Sindical de Trabajadores Mineros de Bolivia (FSTMB) foi fundada em 1944.

O MNR chegou pela primeira vez ao governo central através do golpe de estado de 1943, liderado pelo major Gualberto Villarroel, do grupo militar Razón de Patria (Radepa). Assim como no caso do Radepa, no seu aliado MNR, havia militares que combateram na Guerra do Chaco (1932-1935), na qual a Bolívia perdeu parte do seu território para o Paraguai ${ }^{31}$. Dentre as medidas do governo nacionalista de coalisão

\footnotetext{
${ }^{31}$ A Guerra do Chaco é apontada por diferentes autores como uma das razões da crise do Estado Oligárquico (cf. Rivera, 2003 [1984]; Zavaleta, 2008 [1986]; Urquidi, 2007). Dunkerley (2003 [1987]) ressalta igualmente a crise econômica como uma das razões para a crise vivida pela oligarquia boliviana naquele momento. Segundo o autor, esta crise derivava do cenário de recessão mundial; da
} 
Radepa-MNR, esteve a convocatória do Primeiro Congresso Indígena, em 1945, no qual decretou-se o fim do sistema de servidão para trabalhadores do campo. Contudo, esse governo seria interrompido quando, em 1946, a sede do Poder Executivo foi invadida por uma multidão de moradores da cidade de La Paz. Villarroel foi então enforcado na Praça Murillo, centro político boliviano.

Segundo Silvia Rivera, as razões do assassinato de Villarroel enconrtam-se nas mudanças políticas que ele desencadeara: “com o fuzilamento de proeminentes representantes da ,rosca ${ }^{\text {ee }}$ havia-se vulnerado o que era considerado intocável: a impunidade do senhorio. Mas, além disso, havia-se permitido uma invasão de índios no único terreno hegemônico que a oligarquia conservava: o espaço físico da sede do governo" (2003 [1984]: 103, tradução minha) $)^{32}$.

\subsection{A Revolução Nacional de 1952 e o novo Estado ${ }^{33}$}

As eleições convocadas para 1951 foram anuladas em função da vitória do MNR e um governo militar assumiu o governo. No entanto, a anulação desencadou um golpe de estado organizado pelo MNR: grupos armados de trabalhadores fabris e mineiros, além de diferentes setores urbanos tornaram-se protagonistas da Revolução de abril de 1952 e Victor Paz Estenssoro, fundador do MNR, retornou do exílio para ser o primeiro presidente boliviano do período pós-revolucionário ${ }^{34}$.

desvalorização do principal produto de exportação do país, o estanho, ao longo da Segunda Guerra Mundial; e da maior intervenção estadunidense nas minas do país.

${ }^{32}$ A oligarquia mineira na Bolívia era conhecida como a "rosca". Como explica Dunkerley, "sua influência nos assuntos fiscais do Estado e seu poder político eram tão grandes que justificavam o apelativo de Superestado mineiro que recebeu", (2003 [1987]: 28, tradução minha). O autor aponta que três empresas familiares controlavam $80 \%$ da produção de estanho, que representavam $80 \%$ das exportações nacionais (ibid.: 29).

${ }_{33}^{33}$ Para informações sobre este período ver Dunkerley (2003 [1987]) e Rivera (2003 [1984]).

${ }^{34}$ Antes que Paz Estenssoro chegasse do exílio, outro fundador do MNR, Siles Zuazo, assumiu a presidência do país temporariamente. 
A criação do Estado de 52 foi um marco fundamental da reorganização política da Bolívia e da construção estatal moderna no país ${ }^{35}$.

O programa político do MNR era muito mais moderado do que as ambições daqueles que armados derrubaram o governo de facto nos primeiros dias de abril. James Dunkerley descreve o novo presidente como "um político mais inteligente e pragmático no molde populista do que um ideólogo" e possuidor de "uma sensibilidade conservadora inflexível” (ibid.: 71, tradução minha). Sobre o papel dos dirigentes no MNR, Silvia Rivera afirma que "estes jovens profissionais criollos terminaram impondo um rumo burguês a um movimento onde todos, menos a burguesia, haviam participado" (2003 [1984]: 119, tradução minha).

Dentre as primeiras medidas do governo revolucionário estava a instituição do voto universal, e, sob forte pressão do movimento sindical, a nacionalização das minas do país ${ }^{36}$.

A Central Obrera Boliviana (COB) foi criada poucos dias após o triunfo da Revolução. Em um primeiro momento, o movimento operário participou diretamente da revolução e, alguns dirigentes, como o importante líder mineiro Juan Lechín, ocuparam cargos ministeriais. Em função desta participação, os primeiros anos após a Revolução são considerados um período de cogoverno entre o MNR e a COB.

Logo após o triunfo da Revolução, o exército foi substituído pelas milícias formadas por operários. Contudo, não era todo o operariado que estava articulado com o MNR, pois, desde 1953, o governo perseguiria lideranças do Partido Obrero

\footnotetext{
${ }^{35}$ A Revolução de 52 é caracterizada por Zavaleta Mercado como um dos momentos constitutivos da história boliviana: "no sentido que usamos, [momento constitutivo] refere-se à forma que adquire o tom ideológico e as formas de dominação do Estado, ou seja, ao momento de sua construção" (2008 [1986]: 10 , tradução minha).

${ }^{36} \mathrm{O}$ projeto de nacionalização dos sindicatos era muito mais ambicioso do que aquele levado a cabo pelo o MNR, já que defendia o controle operário das minas e sua nacionalização sem indenização, demandas que não foram tomadas em conta pelo novo governo (Dunkerley, 2003 [1987]).
} 
Revolucionário (POR). Em sua autobiografia, Filemón Escobar (2008), dirigente do POR, conta como foi preso ao lado de Guilhermo Lora, em 1961, e outros 12 dirigentes de partidos de esquerda (inclusive da ala esquerda do MNR), dos mineiros e da $\mathrm{COB}^{37}$. Como salienta Escóbar, essas prisões ocorreram em um momento em que o vicepresidente do país era o dirigente mineiro Juan Lechín.

Progressivamente, o MNR perdeu o apoio da $\mathrm{COB}$ e esta foi deslocada pelos camponeses como base de sustentação do governo. Com essa mudança, milícias camponesas foram usadas pelo governo para enfrentar milícias de operários.

A Revolução de 52 teve consequências fundamentais para a organização da população indígena camponesa do país. Em primeiro lugar, em 1953, o governo revolucionário promulgou a reforma agrária. A reforma foi desencadeada por uma série de ocupações de haciendas por parte da população rural do Ocidente boliviano. Em segundo lugar, o projeto "modernizador" do novo Estado buscou eliminar do discurso político a palavra "índio" e estabelecer uma nova relação entre o Estado e a maioria da população rural do país através dos sindicatos, reforçando o discurso da mestiçagem e a identidade camponesa desses atores.

A reforma agrária produziu efeitos distintos em função da diversidade existente entre as regiões do Altiplano. Antes das invasões de terras que acompanharam o ciclo revolucionário da década de 1950, houve, em diferentes comunidades das Terras Altas, rebeliões indígenas "localizadas na fronteira comunitária que a expansão latifundiária ameaçava transbordar de forma permanente" (Rivera, 2003 [1984]: 79, tradução minha). Da luta contra a espoliação das terras comunitárias, surgiu o movimento de "caciques

\footnotetext{
${ }^{37}$ Gilhermo Lora, dirigente histórico do POR, já havia sido preso nos primeiros anos da Revolução. Os presos políticos eram enviados a lugares isolados. O grupo de Escóbar foi levado a Puerto Villaroel, uma área de floresta no departamento de Cochabamba, outros dirigentes mineiros levados a San Ignacio de Velasco, a quase $500 \mathrm{~km}$ da cidade de Santa Cruz e um grupo de aproximadamente meia centena de dirigentes mineiros foi enviado ao departamento do Beni, no meio da Amazônia boliviana (Escóbar: 56).
} 
apoderados" que, nas primeiras décadas do século XX, reivindicou o reconhecimento pelo governo da posse legítima de suas terras, por meio da recuperação de títulos de propriedade emitidos pela coroa espanhola, durante a época colonial. Essa organização, anterior à Revolução, em defesa das terras comunitárias terá grande influência nos efeitos da reforma agrária nas Terras Altas, na penetração do sindicato camponês e nas atuais formas de organização social de diferentes regiões do Ocidente.

Como a reforma agrária foi concebida com a perspectiva de desenvolver o capitalismo no campo, ela representava, em alguns casos, um perigo para a manutenção de organizações comunais, como no norte do departamento de Potosí, por exemplo. Nessa região, houvera, ainda no século XIX, uma forte mobilização em defesa dos títulos de propriedade comunitários, após a promulgação da Ley de Exvinculación (1874), que impediram, em grande medida, a distribuição de terras por parte do governo boliviano da época (Rivera, $2003[1984])^{38}$. Assim, para as comunidades indígenas do norte potosino, a reforma agrária não era uma demanda, e sim a possibilidade de um processo desarticulador da organização comunal (ibid.). Nessa região, os líderes do sindicato imposto pelo governo do MNR não conseguiram substituir as autoridades comunais. Dessa forma, em alguns lugares, a construção do novo Estado e a tentativa de construção da nação boliviana ignoravam as lutas indígenas históricas por uma organização social e política autônoma (Hylton et al., 2011: 16).

Já nas regiões onde o processo de criação de haciendas foi mais exitoso, como no Altiplano de La Paz e nos Vales, a reforma agrária de 1953 foi uma conquista dos camponeses que, armados com seus fuzis da Guerra do Chaco, formaram "milícias camponesas" para expulsar os fazendeiros. Logo, o sistema de servidão de trabalhadores

\footnotetext{
38 “A Ley de Exvinculación, promulgada pelo governo de Frías em 1874, sancionava a substituição da propriedade coletiva do ayllu pela propriedade individual. Em outras palavras, declarava-se legalmente a extinção do ayllu e se pretendia parcelar seu território, individualizando a propriedade comunal, mediante dotação de títulos individuais" (Ticona, 2003: 1, tradução minha).
} 
nas haciendas, que havia sido abolido apenas formalmente pelo governo de Villarroel na década de 1940, chegou ao fim com a reforma agrária de 1953. Após a reforma, os camponeses que trabalhavam nas haciendas se organizaram em sindicatos, favorecendo, neste caso, a articulação interna dos indígenas e desses com o Estado.

No caso das áreas de haciendas, a reforma agrária reconheceu não apenas a propriedade individual da terra de seus antigos trabalhadores, mas também da população indígena que vivia em comunidades. Ao mesmo tempo, foram emitidos títulos proindiviso, ou seja, títulos de propriedade coletiva sobre determinadas parcelas de terra (Urioste et al., 2007). Os antigos latinfundiários receberam igualmente títulos individuais que, em muitos casos, abarcavam extensões de terra bastante superiores àquelas tituladas aos camponeses (ibid.) ${ }^{39}$; reproduzindo as diferenças sociais anteriores (Lagos, 1994).

\section{2. $O$ ciclo de ditaduras militares (1964-1982)}

Entre 1952 e 1964, foram realizadas três eleições presidenciais, todas vencidas pela mesma corrente do $\mathrm{MNR}^{40}$. Em 1956, Hernán Siles Zuazo substituiu Paz Estenssoro, que voltou à presidência em 1960 e foi reeleito em 1964. Contudo, a primeira fase do Estado criado pela Revolução de 1952 chegaria ao fim em setembro de 1964, com a queda do presidente Paz Estenssoro, destituído por seu vice-presidente, René Barrientos. Dentro de um contexto sul americano no qual as ditaduras militares se tornariam regra, poucos meses depois do golpe de estado no Brasil, iniciou-se na

\footnotetext{
${ }^{39}$ Rossana Barragán apresenta a história da Hacienda de Patarani. Em um primeiro momento, em 1957, seu proprietário recebeu o título de 80 hectares da antiga propriedade, enquanto os antigos colonos receberam 10 hectares cada um, e os novos colonos receberam 5 hectares cada. Em 1963, uma nova sentença concedeu 150 hectares para o proprietário. Em 1979, depois de 26 anos de luta dos colonos, a justiça revalidou a sentença inicial (Urioste et. al., 2007). Guarachi (2005) aponta que, em 2000, Patarani decidiu substituir o sindicato pela forma de organização com autoridades originárias.

${ }^{40}$ Naquele momento o partido estava dividido (cf. Dukerley, 2003 [1987]).
} 
Bolívia um período de ditaduras militares que perduraria até princípios da década de oitenta. Houve restrições dos direitos políticos, a COB foi declarada ilegal e líderes sindicais, principalmente mineiros, foram presos e assassinados. Foi durante o governo de Barrientos que ocorreu o ataque do Exército aos mineiros das minas de Siglo XX e Catavi, em uma chacina que ficou conhecida como o "massacre de San Juan". O campo, porém, manteve-se como base de apoio do governo e formalizou-se o "pacto militarcamponês".

Para Silvia Rivera (1983), o golpe de 1964 e o pacto militar-camponês marcaram uma importante virada na relação entre o movimento camponês e o Estado. A "subordinação ativa" teria se tornado "subordinação passiva". A autora aponta igualmente um crescente afastamento entre os líderes sindicais e suas bases. Rivera explica:

Através do pacto, o exército assume o controle direto do funcionamento do aparato sindical camponês, e garante a eficácia das tarefas de controle preventivo da população através da Ação Cívica das Forças Armadas e entidades estatais controladas pela burocracia militar como as alcadías e prefeituras departamentais (ibid.: 137, tradução minha).

Entre a morte de Barrientos, em 1969, e a chegada ao poder do general Hugo Banzer, houve três golpes de Estado. Em 1971, Banzer assumiu a presidência derrubando o governo do general progressista Juan José Torres e instaurando uma ditadura que se estenderia por sete longos anos ${ }^{41}$.

As ditaduras de Barrientos e Banzer tiveram ademais uma influência na atual estrutura fundiária boliviana. Ao mesmo tempo em que nos Vales e no Altiplano a

\footnotetext{
${ }^{41}$ A ascensão de Torres ao poder havia criado um clima político propício para a instauração da "Assembleia Popular", por iniciativa da COB, que havia recusado o convite de Torres para participar do governo. Esse ",órgão dos trabalhadores e do poder popular" completamente independente do governo provocou uma marcada transformação do clima político" (Dunkerley, 2003 [1987]: 234, tradução minha).
} 
reforma agrária consolidou a existência de pequenas propriedades familiares, no Oriente, consolidou-se um sistema de latifúndios. Antes da reforma, nos departamentos de Santa Cruz e Beni, a área utilizada para agricultura por pequenos produtores superava a superfície cultivada por haciendas, diferentemente do que ocorria no Ocidente (Soruco, 2008: 53). Depois da Revolução Nacional de 52, o governo boliviano destinou a maior parte dos empréstimos para a produção agrícola nos departamentos do Oriente. $\mathrm{O}$ desequilíbrio entre as duas regiões do país aumentaria durante as ditaduras militares. Sem ter em conta a histórica presença indígena na região, e partindo da ideia de que o Oriente boliviano constituía uma região com vastas terras "sem donos", Barrientos e Banzer distribuíram terras entre seus aliados políticos. As novas propriedades tinham milhares de hectares e, em alguns casos, dezenas de milhares.

Essas duas facetas da reforma agrária têm consequências importantes na Bolívia atual. Por um lado, o aumento populacional no Altiplano impede que a terra distribuída em 1953 atenda às necessidades atuais da terceira geração de famílias tituladas ${ }^{42}$. Por outro lado, criou-se uma estrutura agrária altamente concentrada no Oriente, impedindo o acesso à terra por parte do campesinato boliviano.

O fim da aliança entre autoridades camponesas e o governo boliviano teve como marco a repressão a camponeses, em 1974, no episódio conhecido como o "massacre do vale", quando uma manifestação camponesa foi reprimida pelo governo de Banzer. A mobilização havia sido desencadeada por medidas econômicas adotadas pelo presidente de facto, como a redução de subsídios a produtos da cesta básica. O evento ocorreu em Tolata, no departamento de Cochabamba, justamente a região do país na qual o pacto militar-camponês havia tido maior êxito.

\footnotetext{
${ }^{42} \mathrm{O}$ não reconhecimento, em muitos casos, do direito de herança à terra das mulheres e a migração de parte importante da população rural para as cidades foi central para que a atual (super) exploração das propriedades familiares rurais do Altiplano continuasse viável (Urioste et al., 2007). Manteve-se, então, nas últimas três décadas, a média de uso da terra em 1,5 hectares (ibid.).
} 
Segundo Silvia Rivera (1983), o governo de Banzer entrou em crise a partir do esgotamento do modelo econômico escolhido, que havia gerado um crescimento astronômico da dívida externa e uma deterioração dos salários reais ${ }^{43}$. Já para James Dunkerley, a despeito da crise econômica que o país enfrentava, "as principais fissuras no edifício da ditadura foram de natureza fundamentalmente política e superestrutural" (2003 [1987]: 283, tradução minha).

Com o governo enfraquecido, uma greve de fome foi iniciada por esposas de mineiros e representantes da Igreja Católica. Aderiram também à greve centenas de pessoas em todo o país, conduzindo a ditadura de Banzer ao seu fim.

\subsection{A democracia pactuada e excludente e a Nova Política Econômica}

Depois do enfraquecimento da ditadura de Banzer, foi longo o caminho até a mudança definitiva do regime. Entre as eleições convocadas pelo general Banzer, em 1978, e a volta à democracia, em 1982, houve quatro golpes de estado e diferentes eleições foram anuladas. Nesse intervalo, o país viveu as curtas e sangrentas ditaduras do coronel Alberto Nautsch Busch e do general Luis García Meza ${ }^{44}$.

O governo que assumiu em 1982 era formado por uma coalisão de centroesquerda, a Unidad Democratica y Popular (UDP). O novo presidente, Hernán Siles Zuazo, era um dirigente histórico do MNR e havia sido eleito presidente da Bolívia pela primeira vez em $1956^{45}$.

\footnotetext{
43 James Dunkerley explica que, mesmo para os padrões latino-americanos da época, o volume de empréstimos tomados pela Bolívia foi notável (2003 [1987]: 279).

${ }^{44}$ Em 1995, García Meza foi condenado a 30 anos de prisão pelos inúmeros cometidos crimes durante a sua ditadura.

${ }^{45}$ Hernán Siles Zuazo era filho do ex-presidente boliviano Hernando Siles (1926-1930) e havia sido membro do Parlamento desde seus 25 anos de idade. Havia fundado o MNR, ao lado de Victor Paz Estenssoro (Dunkerley, 2003 [1987]: 69).
} 
O novo governo herdou de seus antecessores uma crise econômica que se agravou com o baixo preço do estanho no mercado mundial. Além da grave crise econômica, o governo enfrentou uma importante oposição do Legislativo e se mostrou incapaz de manter o apoio das principais organizações da sociedade civil: a Central Obrera Bolivia (COB) e a Confederación Sindical Única de Trabajadores Campesinos de Bolivia (CSUTCB). Ambas haviam sido os atores centrais no processo de retorno ao regime democrático protagonizando, em 1979, uma greve geral que Zavaleta Mercado aponta como o "maior ato de separação das massas fundamentais em relação ao modelo hegemônico do Estado de 52" (1983: 22, tradução minha). Com a rejeição de Siles Zuazo à estratégia de co-governo proposta pela $\mathrm{COB}$ e pela $\mathrm{CSUTCB}$, e com a falta de apoio do Presidente ao Projeto de Lei Agrária Fundamental elaborado pela confederação camponesa em 1984, grandes mobilizações sociais foram organizadas contra o governo (Rivera, 2003 [1984]). Durante esse período, a COB liderou diversas greves e marchas que culminaram na greve geral de março de 1985.

Com o agravamento da crise econômica e sem apoio das principais organizações sociais ou do Parlamento, Siles Zuazo convocou eleições antecipadas para 1985. Victor Paz Estenssoro foi então eleito com a tarefa de controlar a crise econômica e política que havia inviabilizado o governo anterior. Com a antecipação do término do governo da UDP, iniciou-se um novo período de coalisões políticas relativamente estáveis, marcando uma rearticulação do campo da política institucional em torno de personagens centrais da história do país pós-Revolução de 52 e de um consenso no que tange ao modelo econômico adotado.

Paz Estenssoro iniciou seu quarto mandato presidencial em 6 de agosto de 1985. No dia 29 daquele mesmo mês, seu governo lançou o programa batizado de Nova Política Econômica. Elaborado pelo então ministro da economia e futuro presidente 
boliviano Gonzalo Sánchez de Lozada, o novo programa foi instituído através do Decreto Supremo 21060. Tal como está descrito no decreto, o objetivo da Nova Política Econômica seria:

Atacar as causas centrais da crise no marco de uma racionalidade de medidas fiscais, monetárias, cambiais e de ajuste administrativo do setor estatal que, além de seu conteúdo, radicalmente anti-inflacionário, estabeleça os fundamentos para reiniciar, redefinir e encaminhar o desenvolvimento nacional libertador, dotado de profundo conteúdo social que resgate os valores morais do povo boliviano (DS 21060, tradução minha).

Em 1985, na retórica do novo governo, ruptura era a palavra de ordem. Em seus discursos, Paz Estenssoro, dirigente histórico do MNR e primeiro presidente após a Revolução Nacional de 52, evocava o "fim do período revolucionário de construção nacional" e a "necessidade de começar um novo período de reestruturação e modernização do Estado" (apud. Ströbele-Gregor, 1994: 122, tradução minha). Essas construções discursivas sugerem que a perda da legitimidade do modelo de Estado de 52 se deu não apenas de baixo para cima, a partir da mobilização social, mas também, de cima para baixo, a partir do próprio governo.

Atores e autores têm um discurso similar sobre esse período de reforma do Estado e da economia. As políticas adotadas, qualificadas unanimemente como “neoliberais". Garcia Linera (2008a) e Xavier Albó (2009) apontam o ano de 1985 como aquele que marcaria o fim do Estado de 52. Corroborando a tese desses autores, Juliana Ströbele-Gregor afirma que, embora determinadas políticas de governos anteriores possam ser qualificadas de "neoliberais", 1985 marcaria uma "virada total" na direção da construção de um Estado neoliberal. A autora sublinha:

As bases da economia nacional e sistema estatal de serviços sociais que caracterizavam o modelo de acumulação com intervenção estatal permanecem intactos, em sua estrutura 
básica, até 1985. Foi então quando a modernização neoliberal deu fim concreto e ideológico ao que sobrou das "conquistas da revolução" (Ströbele-Gregor, 1994: 110, tradução minha).

As medidas adotadas consistiam na abertura do mercado para bens importados e transações financeiras, liberalização do sistema de preços, congelamento de salários, redução dos gastos estatais, demissão em massa de trabalhadores e redução do papel regulador do Estado (cf. Ströbele-Gregor, 1994; Garcés, 2010). Ainda que, em seu objetivo de combate à inflação, as medidas implantadas tenham sido bastante eficientes, elas tiveram um alto custo social. Além das demissões em massa, a introdução das novas políticas levou a crise às áreas rurais, com a diminuição dos créditos oferecidos pelo governo (cf. Ströbele-Gregor,1996; Van Cott, 2003; Healey, 2009).

Uma das principais consequências para o campo político boliviano foi a desarticulação da Central Obrera Boliviana, com o enfraquecimento do movimento mineiro. A $\mathrm{COB}$, que havia sido a principal organização da classe trabalhadora boliviana desde a Revolução de 52 e protagonista na luta pela reconstituição do regime democrático, enfrentou uma grave crise na segunda metade da década de oitenta. Uma parte significativa daqueles mineiros que haviam sido demitidos migrou para as periferias dos grandes centros urbanos. No caso da cidade de El Alto, por exemplo, a participação desses antigos trabalhadores mineiros terá grande impacto na organização local. Outro grupo migrou para a região rural de Chapare, em Cochabamba, onde florescia uma nova região do cultivo de coca. Os antigos mineiros tiveram uma grande influência no movimento cocaleiro dessa região, que se tornaria um ator central no campo político boliviano a partir da década de 1990. Foi igualmente a partir do movimento cocaleiro que Evo Morales foi lançado à política nacional. 
A Nova Política Econômica pôde ser adotada apenas a partir da maioria parlamentar alcançada através do "Pacto pela Democracia", entre o MNR e a Ação Democrática Nacionalista (ADN), de Hugo Banzer, antigo inimigo político de Paz Estenssoro. Inauguram-se aqui os inúmeros pactos que marcaram a história das primeiras décadas de redemocratização na Bolívia, e que desembocaram na crise partidária nos primeiros anos do século XXI. Mais tarde, faria igualmente parte dessa articulação o Movimiento de Izquierda Revolucionario (MIR), que havia participado do governo de Siles Zuazo.

Usa-se o termo "democracia pactuada" para se referir à forma pela qual se dava a política institucional boliviana, através de acordos entre lideranças dos principais partidos políticos, MNR, MIR e ADN e de partidos menores. O MNR, criado em 1942, liderou a Revolução de 52 e foi o principal partido boliviano nas décadas seguintes. $\mathrm{O}$ MIR e a ADN foram criados durante o período ditatorial. Logrou-se assim uma estabilidade institucional, cujo alicerce foi a ausência de disputa entre projetos políticos significativamente distintos e a impossibilidade de influência de representantes da maioria indígena e trabalhadora do país na política institucional em nível nacional.

Durante duas décadas, esse sistema garantiu a alternância dos principais partidos no comando do Palácio Quemado, sede do Poder Executivo nacional, e o controle desse sobre o Legislativo. De acordo com a Constituição Política boliviana vigente naquele período, caso nenhum candidato à presidência recebesse uma votação superior a $50 \%$ dos votos válidos, cabia ao Congresso escolher o presidente a partir de uma lista com os três primeiros colocados. Esse foi um mecanismo determinante no funcionamento do 
sistema político boliviano, pois, até a década de 2000, nenhum candidato conseguiu a maioria dos votos dos bolivianos ${ }^{46}$.

Além da prática do clientelismo, com a distribuição de cargos públicos entre membros dos partidos aliados, a "democracia pactuada" se caracterizou igualmente por ter caminhado de mãos dadas com políticas econômicas de caráter neoliberal. Segundo Mayorga, ainda que esses acordos adotassem diferentes características ao longo dos diferentes governos, a democracia representativa, "baseada no sistema de partidos, e coalisões parlamentárias e de governo", e o neoliberalismo econômico eram os eixos discursivos do princípio hegemônico "capaz de ordenar as práticas e discursos dos partidos relevantes" durante aquele período (2009: 130, tradução minha). Outra característica importante da "democracia pactuada", segundo Calderón e Gamarra (2004), era a concentração do poder decisório no Executivo, dentro do qual as principais reformas foram elaboradas por tecnocratas. Nesse cenário, explicam os autores, os partidos no Congresso se limitavam a aprovar as leis elaboradas nos diferentes ministérios. O "caudilhismo político" era outra característica central dos acordos, entre partidos políticos que eram controlados por "caudilhos que trasladaram ao Estado o sistema patrimonial de seus partidos" (Prats, 2005: 4, tradução minha). Para Calderón e Gamarra (2004), o caudilhismo teve como consequência a falta de democracia interna e a incapacidade de recrutar e promover novos líderes, além de uma tendência ao nepotismo.

Para que esse acordo entre elites políticas e econômicas pudesse perdurar, foi fundamental a desarticulação do movimento operário e o enfraquecimento da $\mathrm{COB}$ nos primeiros momentos de mudança na organização política e no modelo econômico

\footnotetext{
${ }^{46}$ Em 1985, o ex-ditador Hugo Banzer havia ficado em primeiro lugar na votação popular, mas como não alcançou mais de 50\% dos votos, coube ao Parlamento escolher o novo presidente, Victor Paz Estenssoro, dentre os candidatos mais votados.
} 
adotado. Com o intuito de frear os protestos contra a nova política econômica, o governo de Paz Estenssoro decretou, em mais de uma ocasião, estado de sítio no país. O fracasso da Marcha pela Vida, organizada pela Central sindical em 1986, contra as medidas implantadas com a Nova Política Econômica, e que foi fortemente reprimida pelo governo, é considerado o ponto irreversível do enfraquecimento do movimento mineiro. A partir desse momento, os trabalhadores mineiros perderam sua capacidade de organização política e o papel hegemônico que haviam tido dentro da sociedade civil organizada. Para García Linera, "a visão do mundo neoliberal só pôde tornar-se proeminente porque previamente foi dissolvido, ou melhor, dissolveu-se, o sujeito gerador de todo um irradiante sentido de mundo" (2008b: 164, tradução minha).

Em síntese, a crise iniciada durante o governo Banzer, na década de 1970, a partir da crise econômica e da ruptura do pacto militar-camponês, havia levado à volta da democracia e à desarticulação de duas bases fundamentais do Estado de 52: o papel protagonista do Estado como agente econômico e sua relação com o campesinato, base de sustentação do regime desde a década de 1960, através de uma estrutura sindical sob controle estatal.

O campo político boliviano se tornou mais complexo nesse período, com a emergência de novos atores que não gravitavam mais em torno do campo da política institucional, como os novos sindicatos camponeses e as organizações indígenas.

\subsection{Indígenas e Camponeses: a formação das organizações}

O processo de instauração da democracia esteve diretamente relacionado ao nascimento de duas estruturas autônomas ao Estado, fundamentais na articulação do campesinato boliviano e dos indígenas das terras baixas: a Confederación Sindical 
Única de Trabajadores Campesinos de Bolivia (CSUTCB) e a Confederación de los

Pueblos Indígenas de Bolivia (Cidob). O surgimento dessas organizações indicava uma ruptura importante com o Estado de 52, que tinha como pilar o apoio do campesinato boliviano a partir de sindicatos sob controle estatal.

A CSUTCB foi criada em 1979, momento em que o pacto militar-camponês se mostrava enfraquecido e buscava-se formar uma organização independente do governo $^{47}$. A formação da confederação foi resultado do fortalecimento do movimento katarista dentro da estrutura sindical até então existente. O movimento formado por intelectuais aymaras foi fundamental para a atualização do discurso sobre a questão étnica no debate político boliviano da década de $1970{ }^{48}$. O nome "katarista" faz referência ao líder indígena Tupac Katari que, no século XVIII, ao lado de Bartolina Sisa, liderou a mais importante rebelião indígena contra o domínio espanhol na região que atualmente conforma o território boliviano.

Ao reafirmar a opressão cultural e política dos povos indígenas bolivianos, o movimento katarista não negava a sua condição camponesa. O Manifesto de Tiwanaku, primeiro documento oficial lançado, em 1973, pelo movimento katarista, afirmava:

Nós, os camponeses quéchuas e aymaras, assim como os pertencentes a outras culturas autóctones do país, dizemos o mesmo. Sentimo-nos economicamente explorados e cultural e politicamente oprimidos. Na Bolívia não houve uma integração de cultura, mas uma superexposição e dominação, e nós ficamos no estrato mais baixo e explorado dessa pirâmide. A Bolívia viveu e está vivendo terríveis frustrações. Uma delas, talvez a

\footnotetext{
${ }^{47}$ Atualmente, a articulação da Confederação sindical ocorre da seguinte forma: "O ponto de partida da CSUTCB são as comunidades agrárias, organizadas como sindicatos. A associação territorial de vários sindicatos por produção, ayllus etc., forma as subcentrais; estas por sua vez se agrupam em torno das cantonais. E estas últimas devem agrupar-se nas representações provinciais que estão dentro de uma federação departamental, nove no total” (García Linera et al., 2008 [2004]: 132, tradução minha).

${ }^{48}$ Esses intelectuais foram influenciados pela obra do indigenista radical Fausto Reinaga (Albó, 2009). Esse havia formulado a ideia da existência de "duas Bolívias", uma indígena e outra branca, mestiça. Reinaga tinha como referência o marxismo indigenista de Mariátegui, o pensamento anticolonial de Franz Fanon e a luta pelo poder negro nos Estados Unidos (cf. Ticona, 2010; Viana et al., 2010). Em seu principal livro, "La Revolución Índia", Reinaga faz uma referência a Malcom X, ao apontar a proximidade entre o projeto elaborado por ele e aquele do ativista estadunidense (2001 [1970]).
} 
maior de todas, é a falta de participação real dos camponeses quéchuas e aymaras na vida econômica, política e social do país. Pensamos que sem uma mudança radical neste aspecto será absolutamente impossível criar a unidade nacional e um desenvolvimento econômico dinâmico, harmônico, próprio e adequado à nossa realidade e necessidades. A Bolívia está entrando em uma nova etapa de sua vida política, uma de suas características é o despertar da consciência camponesa (tradução minha).

Segundo Xavier Albó (2009), a inovação do katarismo foi ter trazido à tona imagens, símbolos; uma memória que, apesar de reprimida, seguia presente no imaginário da população indígena. Sem negar a estrutura sindical, o katarismo revalorizou as autoridades indígenas da região. Nesse trabalho de reconstrução da memória, seus programas de rádio em aymara teriam sido de extrema importância (ibid.: 146-7).

Garcia Linera (2008a) classifica o desenvolvimento inicial do indianismo katarista como o período formativo de uma nova visão do mundo indianista. Nas palavras do autor, o movimento elaborou uma "construção discursiva, política e cultural, formadora de fronteiras culturais como modo de visibilidade de exclusões e hierarquias sociais" (ibid.: 2, tradução minha).

Logo após a sua criação, em 1979, a Confederación Sindical Única de Trabajadores Campesinos de Bolivia (CSUTCB) atuou em aliança com a COB na greve geral nacional em defesa da volta à democracia. Para Zavaleta Mercado (1983), esse evento é um dos momentos constitutivos da história boliviana, junto com a Revolução de 52. O autor argumenta que o esgotamento do modelo de Estado de 52 teria se tornado nítido na crise de novembro de 1979, iniciada pelo golpe de Estado que levara Alberto Natusch Busch à presidência. Zavaleta explica que desde 1964, houvera um aumento do aparato repressivo do Estado e uma diminuição da efetividade ideológica do 
bloco hegemônico, responsáveis por uma perda de legitimidade do Estado que teria levado a um "vazio" hegemônico (1983: 56-7). Aqui se encontra uma das condições que permitiram a emergência do movimento katarista e, igualmente, uma explicação para o seu êxito.

A Tese Política da CSUTCB, elaborada em 1983, reafirmava o duplo caráter da exploração denunciado pelo movimento katarista: "Ao prolongamento do sistema colonial, somaram-se novas formas de exploração capitalista. [...] Nosso pensamento não admite uma redução unilateral de toda nossa história a uma luta puramente classista nem puramente etnicista” (apud. Rivera, 2003[1984], tradução minha).

Desde o II Congresso Nacional da CSUTCB, em 1983, correntes portadoras de concepções distintas sobre o papel do sindicalismo camponês disputavam a hegemonia no interior da organização (García Linera et al., 2008 [2004]). O I Congresso Extraordinário de 1988 tornou evidente o enfraquecimento da corrente katarista, na medida que "as correntes tradicionais de esquerda, renovadas com elementos do discurso indígena, retomam o controle da CSUCTB” (ibid: 118, tradução minha).

$\mathrm{Na}$ década de oitenta, aparece dentro do movimento sindical uma corrente indianista formada por ex-militantes do Movimiento Indio Tupac Katari (MITKA), os Ayllus Rojos, que se associam aos mineiros de Milluni para formar o Ejército Guerrillero Tupac Katari (EGTK) (Mamani, 2003).

Ao mesmo tempo em que era fundada a CSUTCB, os povos indígenas das terras baixas começavam seu processo de unificação, que culminaria com a criação da Cidob após a volta à democracia, em 1982. Fundada com o nome de Central de Pueblos y Comunidades Indígenas del Oriente Boliviano, a Cidob foi resultado da articulação de chiquitanos, ayoreos, guarayos e guaranis, e hoje representa 34 povos indígenas bolivianos. No processo de coordenação dos indígenas das terras baixas e na formação 
da Cidob, foi importante o papel da cooperação internacional e de diferentes organizações não governamentais (ONG).

Em 1990, os indígenas das terras baixas protagonizaram uma marcha que se transformou em um importante marco da mobilização indígena na Bolívia. A "Marcha pelo Território e pela Dignidade" foi organizada pela Central de los Pueblos Indígenas del Beni (CPIB), afiliada à Cidob. Aqueles que participavam da marcha denunciavam os conflitos agrários e econômicos em territórios indígenas. Além disso, tal mobilização foi um passo relevante para articular esses movimentos indígenas com os do Ocidente boliviano, o que será decisivo na construção de outra organização, o Conamaq, em 1997.

Como resultado da marcha, o governo de Jaime Paz Zamora ratificou a Convenção 169 da Organização Internacional do Trabalho, que reconhecia importantes direitos aos povos indígenas. Outra vitória da marcha foi a titulação dos primeiros territórios indígenas, como o Parque Isibóro Sécure, que se encontra atualmente no centro de uma importante disputa entre a Cidob e o governo ${ }^{49}$.

Os guaranis, que em 1982 haviam participado da fundação da Cidob, fundam a sua própria organização em 1987, a Asamblea del Pueblo Guarani (APG). Essa se tornou uma regional da Cidob, reunindo os guaranis dos departamentos de Santa Cruz, Chuquisaca e Tarija. Assim como no caso da Cidob, ONGs foram importantes no processo de formação da APG. Destaca-se dentre essas ONGs o Centro de Investigación y Promoción del Campesinato (Cipca), formado por jesuítas, dentre eles, o antropólogo Xavier Albó. No começo da década de 1990, a APG começou um trabalho de articulação das comunidades guaranis, revalorizando a antiga forma de

\footnotetext{
${ }^{49}$ Referimo-me ao conflito de Tipnis, que será abordado no capítulo 4.
} 
organização social e política, as "capitanias", que haviam sido substituídas pelos sindicatos (Postero, 2009: 109).

A partir da década de 1980, incia-se no sul do departamento de Oruro e no norte de Potosí, uma reorganização das comunidades indígenas, com a conformação de organizações regionais articuladoras dos ayllus locais. Essa reorganização culminaria na formação do Consejo Nacional de Ayllus y Markas del Qullasuyu (Conamaq), que reivindica como objetivo a reconstituição dos ayllus e suyus, do antigo Qullasuyu. A reorganização local consistiu, em grande medida, na reestruturação das comunidades que haviam sido organizadas em sindicatos a partir da Revolução de 1952, recuperando os cargos de autoridade tradicionais. Entretanto, a "transformação", em muitos casos, não implicava em uma mudança radical na estrutura de poder, pois, como diferentes autores afirmam, a estrutura comunitária do ayllu havia sobrevivido dentro da forma de organização sindical (cf. Rivera, 2003 [1984]; Regalsky, 2007; Albó, Romero, 2009). É claro que não estamos tratando de estruturas estáticas, mas de estruturas comunitárias que, a despeito das mudanças sofridas ao longo das últimas décadas, mantiveram certas características centrais de organização, como o caráter rotativo e obrigatório de ocupação de cargos na comunidade e o trabalho coletivo.

O processo de reafirmação das autoridades tradicionais foi bastante desigual nas diferentes regiões do Altiplano boliviano. Em regiões dos departamentos de Oruro e Potosí, onde a lógica sindical não havia se imposto como forma de organização da comunidade, reforçou-se a organização ancestral. No departamento de La Paz, onde o sindicato prevalecia, houve sobreposição das duas formas de organização, comunal e sindical (Albó, Romero, 2009). Daniel Tarqui, ex-autoridade indígena, explicava em 2003: 
Estavam guardadas as vestimentas antigas, como os ponchos, as calças (...) tudo isso, aí soubemos que ainda existiam. Então, para isso, no ano de 1997 se reconstituiu o Jach"a Suyu Pakajaqi ${ }^{50}$ e estamos como mallkus $^{51}$ originários, porque antes era sindicato (Guery et al., 2010: 41, tradução minha).

No processo de "reconstituição dos ayllus", foi central o trabalho das lideranças locais e de intelectuais, principalmente indígenas aymaras, reunidos no Taller de Hitoria Oral Andina (Thoa), que nasceu de debates instigados pela socióloga Silvia Rivera com seus alunos, em 1983. O objetivo do Thoa é "recuperar e fortalecer a identidade indígena em todos os âmbitos", incluindo a reconstituição dos ayllus ${ }^{52}$. Com efeito, o trabalho do Taller de repolitização das identidades indígenas dos Andes bolivianos se realizou por meio de outra leitura da história dessa região, com a elaboração e difusão de documentos, depoimentos sobre a história desses povos tanto em aymara como em espanhol (Stephenson, 2002). Segundo apresentação do próprio Thoa, a sua missão é levar a mensagem descolonizadora à academia e às comunidades $^{53}$. Marcia Stephenson ilustra:

A ênfase do Thoa no importante papel dos anciãos das comunidades assim como as influentes contribuições das mulheres na luta por autonomia e autodeterminação exemplifica os esforços dessa nova geração de intelectuais indígenas (2002: 103, tradução minha).

Guery et al. apontam que na década de noventa, o Thoa, junto com outras ONGs envolvidas no processo de reconstituição dos ayllus, e que contavam com financiamento internacional, foram responsáveis pela difusão da Lei de Participação Popular (LPP), da Convenção 169 da Organização Internacional do Trabalho sobre povos indígenas e

\footnotetext{
${ }^{50}$ Encontra-se na região sul do departamento de La Paz.

${ }^{51}$ São chamados mallkus as autoridades indígenas masculinas do Altiplano.

${ }^{52} \mathrm{http} / / /$ thoabolivia.wordpress.com/about/, consultado em 10/01/2013.

${ }^{53}$ http://thoabolivia.wordpress.com/about/, consultado em 10/01/2013.
} 
tribais e da Lei Inra. Buscavam, assim, divulgar informações sobre a formação de Terras Comunitárias de Origem (TCOs), “como uma luta pelo território e não somente pela terra" (2010: 38, tradução minha). Os autores assinalam:

Com respeito a este último aspecto, o movimento de ayllus explicou que como sindicato camponês se luta somente pela terra, enquanto que como indígenas originários se acede ao direito ao território, existindo, portanto, uma diferença entre ayllu e sindicato - desde o ponto de vista territorial e cultural -que até hoje é sustentada (ibid., tradução minha).

A Lei de Participação Popular (LPP) e a criação das Terras Comunitárias de Origem (TCOs) estão inseridas em um contexto de reforma política realizada em meados da década de 1990. As mudanças promovidas pelo governo central boliviano podem ser entendidas como um projeto de expansão estatal, a partir, de um lado, da expansão do que chamo "campo da política institucional", com a criação dos municípios rurais e o reconhecimento das comunidades indígenas; e, de outro, da "presença" do Estado em territórios ocupados tradicionalmente por povos indígenas, por meio do reconhecimento da propriedade coletiva desses povos sobre as Terras Comunitárias de Origem.

No entanto, esse projeto estatal, que virá acompanhado de uma reafirmação da política econômica adotada a partir de 1985, terá limites não negligenciáveis.

\subsection{Remendando a "democracia pactuada": as reformas constitucionais da década de 1990}

O governo de Gonzalo Sanchéz de Lozada (1993-1997) adotou políticas econômicas que são conhecidas como "as reformas neoliberais de segunda geração"; dentre as quais se destaca a privatização de empresas públicas, como a Yacimientos 
Petroliferos Fiscales Bolivianos (YPFB), em um processo batizado de capitalización $^{54}$. O novo governo, no qual um intelectual aymara, Victor Hugo Cárdenas, ocupou a cadeira de vice-presidente, adotou igualmente políticas multiculturais. Foi então reconhecido na Constituição o caráter "multiétnico e pluricultural” da nação boliviana e elaborou-se uma reforma que deveria implantar uma educação intercultural bilíngue.

No contexto das reformas constitucionais, foi promulgada, em 1996, a Lei 1715, conhecida como Lei Inra ${ }^{55}$. Diferentes organizações sociais se mobilizaram em torno do debate dessa lei. A principal central sindical camponesa do país, a CSUTCB, representou uma importante oposição à lei. Com o intuito de pressionar o governo para incorporar algumas demandas à Lei Inra, entre setembro e outubro de 1996, a CSUTCB organizou, em aliança com a Confederación de Pueblos Indígenas de Bolivia (Cidob), e as organizações camponesas, Federación Nacional de Mujeres Campesinas de Bolivia "Bartolina Sisa" (FNMCB-BS) e Confederación Sindical de Colonizadores de Bolivia (CSCB) a "Marcha pelo Território, Terra, Direitos Políticos e Desenvolvimento", também conhecida como a "Marcha do Século" (García Linera et al., 2008 [2004]: 120). Contudo, após negociações com o governo para a incorporação dos territórios indígenas na nova lei, a Cidob abandonou a Marcha.

A demanda inicial dos indígenas das terras baixas, articulados dentro da Cidob, era o reconhecimento dos seus territórios. Poucos anos antes, pressionado pela mais importante mobilização indígena depois da volta à democracia, a "Marcha pelo Território e Dignidade”, o governo de Jaime Paz Zamora (1989-1993) havia assinado a Convenção 169 da Organização Internacional do Trabalho (OIT) sobre os povos indígenas e tribais. Abria-se então espaço para o reconhecimento não apenas da legitimidade, mas também, da legalidade das demandas dos povos e nações indígenas

\footnotetext{
${ }^{54}$ Sánchez de Lozada era um importante empresário do setor mineiro.

${ }^{55}$ Inra é a sigla para Instituto Nacional de Reforma Agrária.
} 
bolivianos. A Lei Inra criou assim as Terras Comunitárias de Origem (TCOs) ${ }^{56}$. Tratava-se de um título agrário concedido a povos e comunidades indígenas que ocupavam historicamente determinada área. O título de propriedade de uma TCO é coletivo, e não é passível de divisão, venda ou reversão. A nova lei estipulava igualmente que as TCOs deveriam ser administradas pelos mesmos indígenas ${ }^{57}$. Como enfatiza uma autoridade indígena da Cidob, a criação das TCOs não foi um presente do governo, mas resultado da luta indígena ${ }^{58}$. Um limite, não desprezível, que a Lei Inra impôs à reconstituição territorial indígena foi o reconhecimento de terras privadas de terceiros dentro das TCOs.

Por seu turno, a CSUTCB denunciou o caráter privatizador da Lei. Ademais, para grande parte das comunidades do Altiplano representadas pela CSUTCB, não interessava uma titulação exclusivamente coletiva da terra (Urioste et al., 2007). A reforma agrária de 1953 oferecia a possibilidade de titulação coletiva (através do título pro-indiviso) e privada de terras dentro de uma mesma comunidade. Com a Lei Inra, a possibilidade de titulação mista desaparece e a comunidade teria que escolher apenas entre titulação de "propriedade privada coletiva", ou "propriedade privada familiar" (ibid.: lvii).

Sue Iamamoto mostra, a partir de um estudo do Centro de Estudios Jurídicos e Investigación Social (Cejis) ${ }^{59}$, que a Lei Inra favorecia em certa medida os trabalhadores rurais, ao "reafirmar a distribuição gratuita de terras a comunidades, além de determinar critérios de equidade de gênero para a distribuição e posse de terras", mas dificultava o cumprimento da função social das propriedades (2008: 50). De fato, para

\footnotetext{
${ }^{56}$ Ver anexo 3.

${ }^{57}$ Com a promulgação da Constituição de 2009, as TCOs devem ser transformadas em Territórios Indígena Originário Camponeses (TIOCs). A partir destes territórios podem ser conformadas as autonomias indígenas. A outra opção é a partir da transformação de um município. Este é o caso de Charagua, analisado no capítulo 5 .

${ }^{58}$ Entrevista realizada em La Paz, setembro de 2012.

${ }^{59}$ CEJIS / FSUTC-AT-SC. Situación y desafios del movimiento campesino cruceño. Santa Cruz, 2006.
} 
garantir o direito sobre a propriedade rural, bastava que seu dono pagasse os impostos correspondentes. Ademais, a Lei matinha em 50 mil hectares o limite máximo destas propriedades (ibid.). "No geral, a lei reproduzia o espírito das políticas neoliberais propostas na época", afirma a autora (ibid.: 51). Segundo Patzi, para os camponeses do Altiplano, a Lei Inra e as titulações de TCOs "não significava[m] mais que um reconhecimento e uma consolidação de seu minifúndio e pobreza" (2011: 204, tradução minha).

A Lei Inra previa que o processo de "saneamento de terras" deveria, em um prazo de dez anos, "executar e aperfeiçoar o direito à propriedade agrária” (Art. 64). Dez anos mais tarde, o processo de titulação de terras havia distribuído títulos referentes a apenas 8,7\% dos 106,7 milhões de hectares previstos (Nuñéz, 2009: 16). Albó assinala que em um primeiro momento, sob o governo constitucional de Hugo Banzer (19972001), a nova lei privilegiou a oligarquia latifundiária de Santa Cruz com a regularização de títulos de propriedades obtidos de forma irregular. Além disso, favoreceu a abertura do mercado de terras e desprezou a distribuição de terras no Oriente a imigrantes andinos (Albó, 2009: 159). Contudo, com a ajuda de um programa da cooperação dinamarquesa iniciado em 1999, a titulação de TCOs nas terras baixas foi largamente utilizada pelos povos indígenas contra as frequentes invasões de seus territórios por terceiros.

Outra reforma importante empreendida durante o primeiro mandato de Sanchéz de Lozada foi a descentralização administrativa. A partir da Lei de Participação Popular (LPP), de 1994, e da Lei de Descentralização Administrativa (LDA), de 1995, possibilitou-se a criação de municípios rurais e se ampliaram as competências e o repasse de recursos em favor dos governos municipais. Em seu artigo terceiro, a LPP define como atores da Participação Popular, as Organizações Territoriais de Base 
(OTBs), “expressas nas comunidades camponesas, povos indígenas e juntasvecinales, organizadas segundo usos e costumes ou disposições estatutárias”. Nesse mesmo artigo, são reconhecidos como representantes das OTBs "os homens e mulheres, capitães, Jilakatas, Kuracas, Mallkus, Secretários(as) Gerais $^{60}$ e outros(as), designados(as) segundo usos e costumes e disposições estatutárias". O artigo sexto afirma que apenas uma OTB será reconhecida por cada unidade territorial. Nos dois artigos seguintes, são definidos como direitos e deveres das OTBs a elaboração de propostas de obras e prestação de serviços públicos, assim como seu controle.

No campo acadêmico, não há consenso sobre as consequências dessa mudança na estrutura estatal. Alguns autores ressaltam importantes limites da nova legislação. Segundo Félix Patzi, por exemplo, a "democracia liberal" que foi implantada nos municípios desmantelou as "formas ancestrais de vida e as práticas políticas comunitárias". Com a Lei de Participação Popular (LPP), "implementa-se no campo a sociedade fundada na separação entre sociedade civil e sociedade política", argumenta o autor (2005: 155, tradução minha).O sociólogo aymara aponta que com a suspensão do controle coletivo, sustentado na prática de rotação de cargos, abriu-se espaço para a corrupção (ibid.: 67). Patzi afirma que a estratégia política do Estado era apropriar-se da proposta "pluri-multicultural" por ser uma opção política mais fácil de manipular do que aquela que reivindicava "autodeterminação" (2007: 133). Dessa forma, o autor indica que o "pluri-multiculturalismo", ao reconhecer os sistemas culturais e simbólicos, neutralizava e anulava a potencialidade do sistema econômico e político comunal, tratando-se de "uma nova estratégia de integração e de perpetuação e universalização do sistema econômico do capital e do sistema político liberal" (2009: 260, tradução minha).

\footnotetext{
${ }^{60}$ São os diferentes nomes que recebem as autoridades em comunidades indígenas e sindicatos.
} 
Sobre o que chama da "retórica do pluri-multi", Silvia Rivera argumenta que ainda que as elites tenham aprendido esse discurso a partir das agendas da social democracia europeia, elas não abandonaram "o desprezo senhorial pelo trabalho manual e pelas línguas, formas de sociabilidade e aportes produtivos e políticos das sociedades indígenas, colocando em evidência seu manejo teórico e meramente ornamental da diversidade cultural" (2003 [1984]: 13, tradução minha). A apropriação dos discursos de reivindicação étnica dos movimentos sociais indígenas, por parte das elites reformistas estaria, segundo a autora, "completamente atados ao desenho imperial, que consiste em converter a maioria indígena e $\operatorname{chola}^{61}$ da Bolívia, em minoria essencializada e ornamental" (ibid.: 25).

Pablo Regalsky afirma que, durante o primeiro governo de Sánchez de Lozada (1993-1997), havia um projeto político que ambicionava neutralizar os governos comunitários para colocar em marcha um mercado de terras. A Lei de Participação Popular (LPP) seria a base política para viabilizar esse mercado e, assim, seria uma ameaça ao sistema jurisdicional comunitário andino (2006: 7). Para o autor e Francisco Quisbert, a LPP procurou separar o indígena de sua terra e estabelecer o capitalismo rural (2008: 175-6). Os autores argumentam que as políticas multiculturais implantadas durante o governo de Sanchéz de Lozada seriam uma tentativa de neutralizar o movimento de autonomização das comunidades, já que, ao criar novos municípios, a LPP deixava as comunidades sob a jurisdição municipal, ou seja, sob o controle do Estado (ibid.).

Xavier Albó assinala como consequências negativas da LPP, a corrupção, conflitos entre grupos locais e o fato de dirigentes de organizações sociais, como a CSUTCB e a Cidob, deixarem as organizações para trabalhar nos governos municipais.

\footnotetext{
${ }^{61}$ Usa-se "cholo" para tratar do indígena ou mestiço que vive nas cidades, apontando uma forma de mestiçagem cultural.
} 
O autor ressalta, entretanto, que esse deslocamento teve efeitos ambíguos, na medida em que as organizações de base podiam gerar novos dirigentes (2009: 157).

Em seu estudo sobre a aplicação da LPP em comunidades guaranis de Santa Cruz, Nancy Postero afirma:

Como os regimes anteriores de cidadania indígena, este novo regime criou categorias de pertencimento e estabeleceu práticas e instituições para definir a fronteira entre aqueles incluídos e os excluídos. [...] as tecnologias políticas subjacentes à LPP funcionam para incluir alguns novos cidadãos e excluir muitos outros. Ainda que seus defensores tenham elogiado a LPP como um remédio para muitas forças discriminatórias da história boliviana, as experiências de seus supostos beneficiários demonstram que em muitos casos as receitas neoliberais reproduziram a doença que pretendiam curar (2009: 182-3, tradução minha).

Para a autora, apesar da LPP ter sido uma resposta às pressões políticas de grupos indígenas e setores populares, esses grupos não foram consultados na elaboração da nova lei (ibid.: 191). Assim como Regalsky e Quisbert, Postero aponta como objetivo das reformas constitucionais em questão, um maior enfraquecimento dos sindicatos e do sistema político coletivista sobre o qual havia se organizado a sociedade civil boliviana, principalmente, a partir de 1952 (ibid.: 197). A autora ressalta que ao terem seu poder diminuído pela LPP, as organizações coletivas tradicionais foram “substituídas pelos partidos políticos controlados pelas elites como a expressão atual do clientelismo coletivista" (ibid.: 198, tradução minha). Desse modo, sua pesquisa indica que, apesar da lei ter possibilitado a participação de grupos indígenas nas eleições municipais, ela aumentou o poder dos partidos tradicionais e de suas elites, já que para participar de uma eleição era necessário filiar-se a um partido (ibid.).

No caso dos guaranis de Santa Cruz, quatro razões centrais explicariam o porquê da LPP não ter representado uma participação política inclusiva: a manutenção do 
racismo; a exigência de novos conhecimentos de difícil acesso aos dirigentes indígenas; a fragmentação das organizações decorrente da aplicação da lei; e, o seu alcance e financiamento limitados (ibid.: 207). No entanto, Postero afirma que possivelmente o efeito mais importante, e não previsto, da LPP foi o surgimento de uma nova forma de ativismo cidadão a partir da participação nas OTBs. A lição mais importante aprendida pelos indígenas diria respeito ao "seu papel como cidadãos que merecem um tratamento igual por parte do Estado" (ibid.: 234, tradução minha). Finalmente, a autora sublinha a atuação dos guaranis, que souberam aproveitar as vantagens das racionalidades neoliberais e resistir a elas quando lhes eram desfavoráveis (ibid.: 267).

Em sintonia com Postero, Fernando Garcés (2010a) afirma que, apesar das "políticas da diferença", que reivindicam a inclusão dos excluídos, poderem esconder formas sutis de dominação, os novos espaços criados a partir das reformas políticas na década de noventa foram usados por organizações e povos indígenas "como um espaço/tempo de acumulação de forças para ganhar visibilidade e conhecer as ferramentas de dominação do inimigo", conformando assim um espaço ambíguo de resistência/dominação (ibid.: 52, tradução minha).

A despeito dos limites apontados acima, outros autores argumentam que a maior possibilidade de participação de representantes indígenas nos níveis locais de poder foium resultado positivo da LPP (cf. Van Cott, 2005; Healey, 2009; Albó, 2009). Segundo Calderón e Gamarra (2004), as reformas organizadas dentro da lógica da democracia pactuada buscavam institucionalizar o sistema que os partidos haviam criado. Contudo, elas possibilitaram o crescimento de uma oposição que colocava em questão os acordos políticos vigentes.

Para García Linera, ainda que o municipalismo não explique os processos de identificação mais amplos, dada sua limitação territorial, a disputa por recursos dos 
municípios levou "um fortalecimento ou reinvenção instrumental de identidades étnicas locais ou provinciais (Norte de Potosí, Oruro, La Paz)" (2003a: 170, tradução minha). Linera observa igualmente, a partir da LPP, uma "objetivação do Estado em regiões antes chegava apenas com a moeda ou o voto" (ibid.).

Em síntese, o que fica claro a partir da análise dos diferentes autores é que o processo de municipalização das áreas rurais não deve ser entendido apenas como um recurso de descentralização do poder político. Tratava-se, de forma aparentemente contraditória, de um projeto de expansão estatal. Desse modo, se por um lado a adoção das chamadas "políticas neoliberais de segunda geração" teve como objetivo reduzir o controle do Estado sobre a economia nacional, por meio, por exemplo, da privatização de importantes empresas estatais, por outro lado, essas políticas foram acompanhadas de uma expansão estatal que pode ser entendida como um projeto de expansão do mercado.

Nas primeiras eleições realizadas depois da promulgação da nova legislação, mais de 500 indígenas e camponeses foram eleitos consejales (vereadores) e alcaldes (prefeitos) (Albó, 2009:156). Na última sessão deste capítulo veremos até que ponto esses resultados eram decorrentes de um processo de cooptação por parte dos partidos, ou uma consequência do processo de fortalecimento de organizações sociais a partir da democratização.

Embora o campo político tenha se ampliado, não parece que foi o suficiente para permitir uma participação satisfatória de grande parte da população boliviana formada por camponeses e indígenas.

Parecem-me pertinentes as interpretações de Patzi (2007), Regalsky e Quisbert (2008) e Postero (2009), que observam nas reformas políticas da década de 1990, uma estratégia de inclusão dentro da estrutura estatal de formas de organização social que funcionavam de forma relativamente autônoma ao Estado. Porém, há outro dado 
importante: não obstante o enfraquecimento do movimento operário na década de 1980 , o consenso entre as elites políticas durante o período da democracia pactuada foi frequentemente questionado por mobilizações populares. O pacto que garantia a governabilidade permitia uma inclusão muito limitada das reivindicações dos atores subalternos organizados. Assim, o caráter excludente e autoritário que assumiu a democracia representativa na Bolívia naqueles anos é corroborado pelo fato de todos os presidentes até 2000 terem recorrido à declaração do estado de sítio para reprimir ações contenciosas. Como mencionado anteriormente, Paz Estenssoro (1985- 1989) declarou estado de sítio duas vezes em 1986, quando a Nova Política Econômica (NEP) estava sendo questionada. Seu sucessor, Jaime Paz Zamora (1989-1993) declarou estado de sítio em 1989, momento em que professores de todo o país haviam organizado uma greve de fome. Como continuou sendo praxe ainda após a volta à democracia, vários

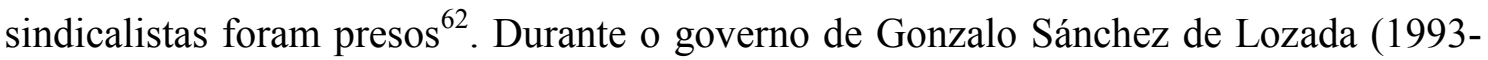
1997), enquanto se defendia uma maior "participação popular", os bolivianos viveram seis meses sob o estado de exceção ${ }^{63}$, com a seguinte justificativa:

\begin{abstract}
Agindo em total desconhecimento das leis da República, a Central Obrera Boliviana definiu o reforço das medidas de pressão, greves de fome, bloqueios, sabotagem de serviços públicos, colocando em risco a paz e a tranquilidade pública (Decreto Supremo 23993, de 18 de abril de 1995, tradução minha) ${ }^{64}$.
\end{abstract}

Filemón Escóbar (2008), antigo dirigente mineiro, relata em sua biografia um evento que caracteriza como "insólito": em 1995, durante o governo de Sanchéz de Lozada, ele foi preso junto a outros dirigentes sindicais e enviado a uma prisão no meio

\footnotetext{
${ }^{62} \mathrm{http}: / /$ elpais.com/diario/1989/11/16/internacional/627174015 850215.html, consultado em 01/02/2014.

${ }^{63} \mathrm{http}: / /$ www.lexivox.org/norms/BO-DS-

24071.txt?token=S7QysqrOtDKwLrYyNLRScvLXdQnWNTIxMDdUss60MgRhY0tDIwsLU0tD61oA, consultado em 01/02/2014.

${ }^{64} \mathrm{http}: / /$ www.lexivox.org/norms/BO-DS-23993.xhtml, consultado em 01/02/2014.
} 
da Amazônia boliviana, no mesmo lugar em que fora encarcerado durante a ditadura de Barrientos, em 1967.

O fato do governo de Sanchéz de Lozada declarar estado de sítio por seis meses para reprimir as mobilizações populares, no mesmo momento em que as reformas em questão estavam sendo aplicadas, indica que a "participação popular" enunciada era limitada, não incluindo a participação da sociedade boliviana nos debates nacionais.

A multiplicidade de formas de organização social e política existentes na Bolívia e as diferentes relações construídas entre os atores e o Estado tornam difícil uma generalização a respeito do impacto das reformas políticas da década de 1990. Se, em alguns casos, tais reformas podem ser vistas como um elemento desarticulador das estruturas locais e organizacionais; em outros, elas foram aproveitadas como uma forma de inclusão numa estrutural estatal que até então era muito limitada. Ao mesmo tempo, um antigo assessor da organização indígena Conamaq entrevistado indica um efeito aparentemente contraditório da LPP: por permitir o avanço na institucionalização de governos locais, essa lei deveria ser entendida como um avanço na direção da construção de autonomias indígenas ${ }^{65}$. Assim, nesse país tão diverso, a maior participação estatal pode ser entendida, em determinadas regiões, como uma possibilidade de fortalecimento das estruturas organizacionais locais e, em outras, como um perigo para formas autônomas de organização social e política. Independente de seus distintos efeitos, é importante sublinhar que esse empreendimento de expansão do controle estatal foi elaborado dentro de um marco republicano de organização territorial e política: os municípios e o sistema de democracia representativa. Ao limitar o reconhecimento das formas autóctones de organização apenas às Organizações Territoriais de Base (OTBs), a nova legislação impunha às comunidades indígenas um

\footnotetext{
${ }^{65}$ Entrevista realizada em La Paz, outubro de 2012.
} 
sistema que lhes era estrangeiro e fronteiras que não correspondiam àquelas das comunidades, ayllus, capitanias etc.

Assim, o processo de construção democrática continuava incompleto. Contudo, foi a partir da criação de municípios rurais que o partido de Evo Morales, Movimiento al Socialismo - Intrumento por la Soberanía de los Pueblos (MAS- IPSP), pode ser fortalecer localmente. Embora houvesse experiências anteriores de formação de partidos que reivindicavam uma representação indígena e camponesa, nenhum teria o sucesso eleitoral alcançado pelo MAS.

\subsection{Indígenas e Camponeses: participação no campo partidário}

No período de transição democrática, ao mesmo tempo em que foram criadas organizações que articulavam o campesinato e as diferentes nações e povos indígenas bolivianos, alguns desses atores optaram pela participação no campo político através do campo partidário. Por um lado, manteve-se a estratégia adotada por parte do campesinato durante o período posterior à Revolução de 1952, e tanto líderes do movimento indígena como do campesinato aliaram-se aos chamados partidos políticos "tradicionais". Por outro lado, houve o que podemos qualificar de um processo de emancipação política com a formação de partidos próprios. Ao longo das últimas três décadas, as duas táticas foram adotadas, às vezes de forma simultânea, resultando em algumas divisões entre os movimentos sociais estudados, e no interior dos mesmos.

No final da década de 1960, havia duas tendências do movimento indígena nos Andes: a katarista e a indianista. Felix Patzi (2007) explica que o katarismo, tendência "mais sindicalista" entre os indígenas andinos, falava da necessidade de reformar o Estado devido ao seu não reconhecimento do pluri-multiculturalismo boliviano. E os 
indianistas, tendência mais política, afirmavam que o caráter pluri-multicultural da Bolívia só seria reconhecido com a autodeterminação das nações originárias. A estratégia da primeira corrente seria, segundo Patzi, ocupar os espaços de poder

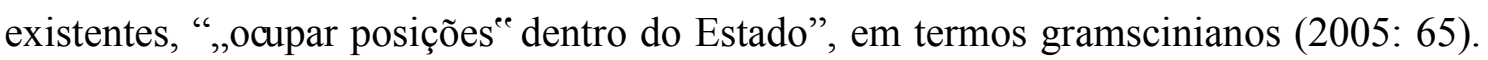
De acordo com Patzi, esses "intermediários culturais" são os primeiros a "denunciar as discriminações e injustiças das estruturas coloniais de dominação" (2007: 39, tradução minha).

Dessas duas tendências nascem, em 1978, os partidos Movimiento Revolucionario Tupac Katari (MRTK) e do Movimiento Indígena Tupac Katari (MITKA). O MITKA, quando comparado ao MRTK, mostrava-se "mais radical em sua denúncia da esquerda $q^{\prime}$ ara ${ }^{66}$ e mais enfático em apontar a opressão e discriminação racial como os principais problemas dos quais sofrem as maiorias populares, tanto operárias como camponesas" (Rivera, 2003[1984]: 170, tradução minha). O MRTK, mais disposto a fazer alianças com outros partidos, apoiou a Unidad Democratica y Popular (UDP). A importância do movimento katarista-indianista é destacada por Silvia Rivera:

O movimento katarista-indianista dos anos 1970-1980 [...] reside em ter construído um novo campo ideológico, descentralizando a leitura estatal homogeneizadora, subvertendo a pax nacionalista e a hegemonia do nacionalismo revolucionário como esquema ideológico integrador, que pela via da nação ou pela via da revolução condenava as populações indígenas a um destino subordinado (Rivera, 2007, tradução minha).

Dentro da CSUTCB e do movimento camponês, a tendência representada pelo MRTK era predominante. Jenaro Flores, um dos principais expoentes do partido, ocupou o cargo de máxima autoridade da CSUTCB, de 1978 a 1988. O seu destaque

\footnotetext{
66 "Q“ara” é a forma pela qual os aymaras referem-se aos brancos, ou não indígenas.
} 
dentro do campesinato não se refletiu, todavia, em grande apoio eleitoral aos candidatos do partido. Embora formalmente aberto à participação indígena, o campo da política institucional mantinha uma estrutura que impossibilitava sua expansão democrática.

Segundo Pedro Portugal, intelectual aymara, o crescimento do indianismo, representado pelo MITKA, e do movimento katarista, representando pelo MTKR, "viuse totalmente perturbado". No primeiro caso, a radicalidade de seu discurso provocava medo, "tocava na essência de ilegitimidade que tem o poder boliviano, porque é um poder que descende dos colonizadores". Para Portugal, o discurso indianista provocava uma reação de "quem tinha o poder político na Bolívia". "E quem tinha esse poder político, institucional, cultural, religioso, militar etc. eram pessoas que justamente descendiam dos espanhóis, como é atualmente. E essa casta o via como uma afronta e um perigo para sua existência”, explica ${ }^{67}$. Dessa forma, esses movimentos não teriam conseguido resistir a uma "avalanche de oposição da parte boliviana", que articulou a oposição à parte mais radical, o MITKA, apoiando a mais "suave", que era o MRTK.

Durante a década de noventa, a estratégia adotada pelo movimento indígena das terras baixas e por parte do movimento das Terras Altas foi a participação nas eleições através dos partidos políticos "tradicionais". Nas eleições municipais de 1995, com a Lei de Participação Popular (LPP) em vigor, candidatos que se autoidentificavam indígenas ou camponeses ganharam 28,6\% dos assentos nas câmaras municipais, alcançando a maioria em 73 de 311 municípios (Van Cott, 2003: 756). É nesse contexto que deve ser entendida a aliança de diferentes organizações afiliadas à Cidob com o Movimiento Nacionalista Revolucionario (MNR), o Movimiento de Izquierda Revolucionaria (MIR) e o Movimiento Bolivia Libre (MBL) (Van Cott, 2005) ${ }^{68}$.

\footnotetext{
${ }^{67}$ Entrevista realizada em La Paz, novembro de 2012.

${ }^{68}$ García Linera et al. explicam que a Cidob permitia a militância de seus membros em partidos políticos, a exceção de seu presidente e secretários, como uma estratégia de preservação da autonomia das
} 
Entretanto, tal estratégia não alcançou os resultados esperados pela Cidob. Em muitos casos, os partidos políticos não aceitavam grande parte da pauta proposta pelas organizações; em outros, os candidatos indígenas eram colocados no final da lista do partido $^{69}$. No caso da aliança com o MBL para as eleições de 1997, embora o partido tivesse aceitado o papel protagonista da confederação indígena, a aliança não foi bemsucedida eleitoralmente (ibid.).

Esse tipo de aliança no campo da política institucional com atores externos às lógicas indígenas teve um efeito perverso no caso da Cidob, levando a uma disputa no interior da organização e o enfraquecimento do seu poder de articulação e integração dos diferentes povos e nações indígenas no campo político nacional e local (ibid.).

Para o movimento indígena das Terras Altas, as alianças com os partidos "tradicionais" foram mais bem sucedidas eleitoralmente. No entanto, apesar dos resultados eleitorais positivos, a participação na política institucional via esses partidos não respondeu às expectativas políticas do campesinato. Assim, a aliança de Victor Hugo Cárdenas, do MRTK, com o MNR de Sanchez de Lozada, em 1994, levou a um maior afastamento entre o movimento camponês e o katarismo, dentro do qual a corrente representada por Cárdenas era a mais expressiva naquele momento.

Pedro Portugal ressalta que embora o movimento indianista e o katarista tenham sido "neutralizados pelo mesmo fenômeno colonial, ainda que de vertentes diferentes", eles "serviram para conscientizar, a parte boliviana que mandava que existia índio e que necessitavam respostas"

organizações indígenas. Marcial Fabricano teria assim sido expulso da Cidob por militar no MIR enquanto ainda era presidente da organização social (2008 [2004]: 265).

${ }^{69}$ A votação se dava pelo sistema de lista fechada.

${ }^{70}$ Entrevista realizada em La Paz, novembro de 2012. 
Em 1995, no Primeiro Congresso Terra e Território foi aprovada a Tese do Instrumento Político das organizações sociais. Nesse congresso participaram a Cidob e as organizações camponesas Confederación Sindical Única de Trabajadores

Campesinos de Bolivia (CSUTCB), Federación Nacional de Mujeres Campesinas de Bolivia "Bartolina Sisa" (FNMCB-BS) e Confederación Sindical de Colonizadores de Bolivia (CSCB) (Stefanoni, 2003). Formou-se então a Asamblea para la Soberanía de los Pueblos (ASP). Sobre as resoluções do II Congresso da ASP, realizado em 1997, Pablo Stefanoni explica:

Da nova síntese proposta pela ASP, emerge a proposta de uma Bolívia Socialista, Multinacional e Comunitária, resultante da superposição da "luta nacional e luta de classes". São definidos como o "novo sujeito da Revolução" os "originários, operários e o campo popular" e é possibilitada a articulação do Pachakuti andino, com o marxismo e a ideia da Terra sem mal do Oriente boliviano, em uma interpelação ao conjunto dos explorados (ibid: 24, tradução minha).

Nas eleições de 1997, a ASP elegeu quatro deputados nacionais, dentre eles, Evo Morales, que foi o candidato mais votado do país (Van Cott, 2003: 756) ${ }^{71}$. Devido à dificuldade em registrar o novo partido, a ASP adotou a sigla de outros partidos nas eleições de 1995, 1997 e 1999. Nas duas primeiras concorreu com Izquierda Unida (IU) e, na última, com o registro do Partido Comunista Boliviano (PCB) (Van Cott, 2003: 763). Esse fato corrobora os limites da abertura do campo da política institucional à participação de setores subalternos.

Em 1998, uma disputa política dentro da ASP levaria à divisão do partido e a criação do Instrumento Político porla Soberanía de los Pueblos (IPSP), sob a liderança

\footnotetext{
${ }^{71}$ Para Donna Lee Van Cott, a criação de cadeiras “uninominais" em 1997 permitiu o sucesso eleitoral de movimentos que eram muito representativos em uma região e que não tinham influência equivalente a nível nacional (2003: 756). Para os distritos "uninominais", os candidatos apresentam candidatura individual, sem participar das listas dos partidos políticos.
} 
de Evo Morales. Devido à impossibilidade de registrar-se como partido, o IPSP usou a legenda de Movimiento al Socialismo (MAS), para participar das eleições de $1999^{72}$.

O crescente fortalecimento do MAS-IPSP nas eleições nacionais contrastou com o enfraquecimento da ASP. Assim, em 2002, quando o MAS-IPSP ficou em segundo lugar na disputa presidencial e elegeu a segunda maior bancada do parlamento, a ASP não apresentou candidatos e seus principais militantes aliaram-se ao partido de Manfred Reyes Villa, o Nueva Fuerza Republicana (NFR) (ibid.: 764). Já como resultado da divisão no interior da Cidob, um grupo aproximou-se do governo e outro aliou-se ao MAS (Albó, 2009: 169). Do Alto e Stefanoni explicam que "o MAS estava tão pouco preparado para se converter, subitamente, na principal força política de oposição que nem tinha suas listas de candidatos completas", como indica o exemplo do resultado eleitoral em Potosí, onde o MAS recebeu o percentual de votos correspondente para eleger dois senadores, sendo que havia apresentado apenas um candidato (2010: 316, tradução minha).

Outro partido político foi formado a partir de uma corrente presente na CSUTCB, o Movimiento Indígena Pachakuti (MIP). Sob a liderança de Felipe Quispe, o MIP foi criado em 2000. Dois anos antes, a eleição de Felipe Quispe como Secretário Geral da CSUTCB havia sido resultado da falta de consenso entre as correntes lideradas por dois líderes camponeses de Cochabamba, a de Evo Morales e aquela sob a direção de Alejo Véliz, que viria a controlar a ASP. Felipe Quispe, que havia sido líder do Movimiento Indígena Tupac Katari (MITKA) na década de 1980, representava uma corrente mais indianista. A diferença central entre o IPSP, sob a liderança de Evo

\footnotetext{
72 "O MAS-U era um desprendimento da Falange Socialista Boliviana que foi girando à esquerda sob a liderança de David Añez Pedraza. O "u” (em homenagem ao líder fascista Óscar Únzaga de la Vega) foi retirado em um congresso partidário e o nome oficial ficou estabelecido como Movimiento al SocialismoInstrumento Político por la Soberanía de los Pueblos (MAS-IPSP). Mantiveram-se, no entanto, as cores partidárias originais: azul e preto" (Do Alto, 2011 : 100, tradução minha).
} 
Morales, e o MIP, residia no fato do primeiro, apesar de ter nascido do movimento cocaleiro, buscar articular-se com outros setores sociais enquanto o MIP apresentava-se como um movimento mais excludente.

Nem Evo Morales, eleito deputado nacional em 1997, nem Felipe Quispe, eleito em 2003, terminaram seus mandatos. O primeiro teve o seu mandato cassado, em janeiro de 2002, acusado de incitar ações violentas entre os cocaleiros que culminaram no assassinato de policiais durante um protesto, embora a verdadeira razão fosse a forte oposição que fazia ao governo constitucional do ex-ditador Hugo Banzer e seu plano de erradicação do plantio da coca na região do Chapare. Já Quispe renunciou ao seu posto de deputado em 2004, depois da aprovação no Parlamento da imunidade a cidadãos estadunidenses. O líder do MIP afirmou na época não poder “estar comprometido com um Congresso que atua de forma arbitrária e pelas costas do povo boliviano",73. $^{\text {. }}$

Sobre a participação do Instrumento Político por la Soberanía de los Pueblos (IPSP) no Congresso após a eleição de 1997, Urquidi assinala que "no Parlamento, o trabalho dos representantes do partido encontrou uma reatualização e rechaço dos deputados citadinos" (2007: 180). Naquele momento, a solução encontrada foi a conformação da Brigada Indígena de Bolivia, "composta por deputados indígenas de diferentes partidos, buscando ampliar os debates de interesse específico dos camponeses-índios" (ibid.). Os episódios descritos acima refletem a dificuldade que enfrentava o movimento indígena e camponês para participar no campo da política institucional. Com efeito, embora a princípio as mudanças legais e o amadurecimento das organizações indígenas e camponesas houvessem permitido a participação de

\footnotetext{
${ }^{73}$ http://www.bolpress.com/art.php?Cod=2002080746, consultado em 15/01/2014.
} 
representantes da parcela majoritária da população boliviana nesse campo, essa presença nas esferas nacionais de poder político não se deu de forma satisfatória.

As eleições de 2002 marcariam um novo momento na política partidária boliviana. Pela primeira vez, os três principais partidos políticos da "democracia pactuada", o Movimiento Nacionalista Revolucionario (MNR), a Acción Democárica Nacionalista (ADN), de Banzer, e o Movimiento de Izquierda Revolucionaria (MIR), tiveram que aliar-se para que um novo partido não chegasse ao poder (Van Cott, 2003: 758). A crise dos partidos tradicionais se refletiu nos votos recebidos pelo MAS e pelo MIP, que alcançaram 27\% do total (Evo Morales recebeu 20,94\% e Felipe Quispe 6,1\%), um crescimento significativo em relação as eleições de 1997, quando os partidos indígenas juntos haviam obtido 4,6\% dos votos (ibid.: 752). E, como apontado, em 2002, o MAS tornou-se o partido com a segunda maior bancada no Congresso.

Sobre a nova composição do Poder Legislativo, Albó afirma:

$\mathrm{Na}$ inauguração do Parlamento, este apresentava, pela primeira vez em seus 173 anos de história, a outra imagem do país, com ponchos, polleras e até um arco e flechas da Chiquitania. Muitos, inclusive, preferiram se expressarem, com emoção e orgulho, em quéchua, aymara e bésiro, razão por a qual foram instalados equipamentos de tradução simultânea. Haviam passado apenas treze anos do ingresso da primeira cholita paceña no Parlamento (2009: 173, tradução minha) ${ }^{74}$.

O sucesso eleitoral do MAS deve ser entendido dentro do contexto de um novo ciclo de crise política que surge na Bolívia a partir de 2000, com a "guerra da água". É essa crise, que analisaremos no próximo capítulo, que permite a abertura do campo político boliviano para uma participação no campo da política institucional nacional de atores oriundos dos movimentos indígenas e camponeses.

\footnotetext{
${ }^{74}$ Cholita é a denominação para as mulheres do Altiplano que se vestem de uma forma específica, que inclui as polleras.
} 
As grandes revoltas populares ocorridas em 2000 e 2005 podem ser entendidas como o auge da crise da forma de articulação entre o Estado e a sociedade boliviana criada com o Estado de 52. O período da democracia pactuada não foi incapaz de realizar uma transição democrática satisfatória, a partir da inclusão de atores subalternos e suas estruturas de organização dentro do campo da política institucional. Ademais, a manutenção de uma política econômica liberal desde 1985 foi um fracasso em termos de melhoria nas condições de vida da população boliviana, conservando o padrão histórico desigual de concentração de riqueza. Segundo relatório publicado pelo Programa das Nações Unidas para o Desenvolvimento (PNUD), os níveis de pobreza no país, em 1997, se mantinham iguais àqueles existentes quando foi lançada a Nova Política Econômica, pelo governo de Paz Estenssoro (PNUD, 2002: 5). Segundo o documento, não apenas a política econômica não foi traduzida em uma redução significativa da pobreza, como manteve taxas instáveis de crescimento econômico (ibid.: 3). Esse era o cenário boliviano quando eclodiu o ciclo de mobilizações sociais que levaria a uma reestruturação do campo da política institucional. 


\section{Capítulo 2 - Crise Política: o descompasso entre o Estado e a sociedade}

La visibilización y rechazo crecientemente colectivo de los variados mecanismos de la dominación política y social que aseguran la capacidad ajena de explotación de la Pachamama y de sus hijos e hijas, habilitó la multitudinaria participación de miles y miles de hombres y mujeres, organizados en sus comunidades, en sus sindicatos, en sus juntas vecinales, en sus federaciones, confederaciones $y$ coordinadoras, para trastocar y modificar ese conjunto de opresivas e injustas relaciones sociales. En esto consistió la apertura de una temporada de Pachakuti ${ }^{75}$ (Gutiérrez, 2008: 18).

No final da década de 1990, o consenso intra-elites, alicerce da democracia pactuada, começa a ser fortemente combatido por setores subalternos, não obstante o enfraquecimento do movimento operário desde meados da década de 1980. Entre os anos de 2000 e 2005, mobilizações populares colocam em questão o modelo econômico, reeditado por todos os governos desde 1985, e o sistema de representação política excludente, que havia tornado possível a eleição do general Hugo Banzer à Presidência da República Boliviana em 1997. O ano 2000 é considerado o marco inicial da última crise política vivida pela Bolívia. Mais uma vez, seria durante um mandato do ex-ditador Hugo Banzer que a estabilidade do regime político vigente seria posta em cheque. Se, em 1974, a repressão à mobilização camponesa em Tolata havia enterrado o pacto militar-camponês; em 2000, as mobilizações em torno do direito à água marcaram

\footnotetext{
75 "Pacha é „tempo, espaço“e e kuti, „mudança, virada“e, tanto em quéchua quanto em aymara. Pachakuti é parte da cosmovisão andina no sentido dos grandes ciclos ou mudanças históricas" (Albó, 2009: 168, tradução minha).
} 
o início do fim da democracia pactuada. A repressão foi a primeira "solução" encontrada por Banzer para responder à insatisfação social. Nos dois eventos, o 1974 e o 2000, a obediência às exigências das instituições financeiras internacionais havia custado caro para seu governo em termos políticos. Na década de 1970, as mobilizações sociais foram desencadeadas por medidas econômicas exigidas pelo Fundo Monetário Internacional. No episódio mais recente, um relatório do Banco Mundial “instruía o governo não subsidiar o aumento nos preços da água para o consumo" (Oliveira et. al., 2008: 19, tradução minha). Ao seguir a instrução, o governo desencadeou a "guerra da água” em Cochabamba.

Uma articulação indígena sem precedentes no Altiplano de La Paz acompanhou a sublevação popular de Cochabamba. Instituiu-se em algumas províncias da região o que podemos chamar de experiências radicais de autonomias indígenas de facto. Em 2003, o palco principal, ainda que não o único, da insurreição popular que desencadeou a "guerra do gás" foi a cidade de El Alto, no departamento de La Paz. Dois anos mais tarde, Carlos Mesa, que havia assumido a Presidência do país depois da fuga de Sanchéz de Lozada em 2003, renunciou e as eleições presidenciais foram antecipadas. Com a vitória de Evo Morales acaba o que chamo de primeira fase do longo ciclo da crise política vivida pela Bolívia entre 2000 e 2008.

Neste capítulo, apresento as diferentes inflexões desta primeira fase da crise política boliviana.

\subsection{Da luta pela água à construção autonômica radical}

O ano de 2000 marcou o início de uma fase de fortalecimento de determinados movimentos sociais bolivianos, e, também, um ciclo mais recente de crise política na 
Bolívia. A revolta popular em Cochabamba, conhecida como "guerra da água", e a insurreição articulada pela Confederación Sindical Única de Trabajadores Campesinos de Bolivia (CSUTCB) no Altiplano de La Paz evidenciaram a desarticulação entre o poder político e a sociedade. Nos dois casos, o campesinato foi um ator central na mobilização social.

A guerra da água foi desencadeada pela transferência do serviço de água e esgoto da cidade Cochabamba a uma empresa privadae pela promulgação da Lei 2029, em 1999, que regulava o sistema de distribuição de água potável e esgoto sanitário. Oscar Olivera, líder sindical e principal porta-voz da Coordenadora em Defesa da Água e da Vida, explica que com a Lei 2029 “todos os sistemas autônomos de água, como as cooperativas, teriam que ser cedidos a eles [empresas privatizadas] sem pagar nada a quem investiu para ter seu próprio sistema" (Olivera et. al., 2008: 21, tradução minha). Além do grande aumento nas tarifas de água dos moradores da cidade de Cochabamba, essas mudanças desarticulariam os sistemas de captação e distribuição de água desenvolvidos por aqueles que viviam em bairros periféricos da cidade e no campo. No campo, esses sistemas eram organizados de acordo com os usos e costumes. Já na cidade de Cochabamba, o sistema central de distribuição de água alcançava apenas metade da população, levando a outra metade a articular-se em cooperativas próprias para construção de poços ou compra de cisternas (ibid.: 20-21) ${ }^{76}$.

Criada em novembro de 1999, a Coordenadora de Defesa da Água e da Vida foi o resultado de uma articulação entre diferentes setores organizados da sociedade. Dela participavam, notadamente, camponeses dos Vales de Cochabamba, organizados na Federación Cochabambina de Regantes (Fedecor) e operários urbanos reunidos na

\footnotetext{
${ }^{76}$ Segundo o Censo de 2012, em Cochabamba, apenas 54\% das residências têm acesso ao serviço de água encanada. Fonte: Instituto Nacional de Estadística, Bolivia Caracteristicas de Población y Vivienda, Censo Nacional de Población y Vivienda 2012.
} 
Federación de Fabriles de Cochabamba, da qual Oscar Olivera era Secretário Executivo.

Nos primeiros meses do ano 2000, camponeses e citadinos participavam das assembleias e cabildos nos quais eram decididas as ações da Coordenadora. Bloqueios foram organizados nas avenidas principais da cidade e nas estradas.

O movimento cocaleiro teve uma participação importante nos bloqueios de fevereiro (ibid.: 40). Em janeiro, Evo Morales, sua principal liderança, participara ao lado de Olivera das negociações com o governo (ibid.: 37).

Entre janeiro e abril de 2000, o governo de Hugo Banzer "simulava" uma negociação com líderes da Coordenadora em Defesa da Água e da Vida ao mesmo tempo em que organizava uma forte repressão às mobilizações de rua. O governo descumpriu os acordos com os representantes dos movimentos sociais e declarou estado de sítio no dia oito de abril, um dia depois de uma marcha haver reunido cinquenta mil pessoas (ibid.). Mandatos de prisão foram expedidos contra os porta-vozes da Coordenadora, mas a forte repressão estatal aumentou a mobilização social e, finalmente, um acordo foi assinado entre o governo e a Coordenadora.

Como resultado do acordo, foi modificada a Lei 2029, Lei de Água Potável e Esgoto Sanitário, e a empresa de água de Cochabamba, Semapa, voltou a ser controlada pelo governo municipal, mas agora em coordenação com representantes indicados pela Coordenadora.

Como fica claro no relato de Oscar Olivera sobre a reação de muitas pessoas após o acordo com o governo, a mobilização social não havia sido desencadeada 
"somente pela água"77. Havia uma enorme insatisfação com o governo Banzer, o sistema político e as políticas macroeconômicas, que reproduziam a exclusão dos setores subalternos. Tal insatisfação se tornará evidente nas diferentes mobilizações sociais que ocorreram após a guerra da água. Em 2006, Abraham Grandidier, representante da Associação de Sistemas Independentes de Água Potável da Zona Sul de Cochabamba, afirmava:

Em todas as discussões e lutas recentes nos demos conta de que o verdadeiro problema não é não ter sistema de água e esgoto, mas que estávamos mal em tudo. Na saúde, por exemplo, de cada 100 crianças dez morrem na zona sul, enquanto no centro e no norte da cidade têm todos os serviços básicos; grandes hospitais, água potável, sistema de recolhimento de esgoto; e morrem menos crianças nesse setor. Na zona sul, de cada 100 crianças, 22 não vão à escola. Estão ficando analfabetas. Lá têm aula entre 60 e 50 alunos em uma sala, essa é a triste realidade da zona sul (Gutiérrez, Escárzaga (coord.), 2007: 70, tradução minha).

\section{Segundo Oscar Olivera:}

A Coordenadora de Defesa da Água e da Vida surge na raiz da perda de credibilidade da população nas diferentes instituições e instâncias que governam o país, as quais se converteram em feudos partidários e instrumentos de imposição, que até agora nos converteram em obedientes impotentes, em eleitores obrigados e em pagadores dos gostos dos ricos (2008: 15, tradução minha).

Em abril de 2000, enquanto em Cochabamba ainda se viam os enfretamentos em torno da questão da privatização da água, camponesesiniciam bloqueios em estradas dos

\footnotetext{
77 “„E... companheiro, o que ganhamos com a guerra da água?ce, perguntava uma mulher que depois de terminados os conflitos em Cochabamba, continuava bloqueando a rua, ao lado de seu marido desempregado e de seus filhos sem saúde nem escola [...] ,Nós queremos que os políticos partam, queremos justiça social" . Nunca esquecerei dessa companheira, da zona de Pampa Grande, onde compram a água das cisternas ou de canais de irrigação: a maioria dos que haviam lutado pela água em Cochabamba não tinham água da empresa que foi desprivatizada pelo esforço da população" (Olivera et al., 2008: 130, tradução minha).
} 
departamentos de La Paz, Cochabamba, Oruro, Chuquisaca e Tarija com a nova Lei de Águas. A atuação da Confederación Sindical Única de Trabajadores Campesinos de Bolivia (CSUTCB) e de seu secretário geral, Felipe Quispe, foi fundamental nessa mobilização ${ }^{78}$.

A retórica de Quispe evocava a lembrança do cerco de La Paz pelo líder indígena Tupac Katari no século XVIII e a revolta liderada no século seguinte por Zárate Willka. Assim como na insurreição indígena da década de 1780, houve escassez de alguns alimentos na cidade de La Paz. Ao mesmo tempo, em diferentes cidades da província de Omasuyus, no mesmo departamento, foram realizados diversos cabildos ou assembleias, que chegaram a reunir alguns milhares de pessoas, em um mesmo dia, em diferentes lugares (Patzi, 2011: 198). Para Patzi, tratava-se do "início da discussão sobre o ocaso da democracia representativa e o surgimento do poder comunal" (ibid.: 198, tradução minha).

Nesse período, destacou-se a insurreição organizada no departamento de La Paz, onde os protestos haviam sido fortemente reprimidos pelo governo ${ }^{79}$. A repressão foi o estopim para o incêndio de instalações do Estado boliviano, como a sede da prefeitura e o quartel policial. A resposta do governo à revolta popular de abril foi a prisão de Felipe Quispe, mas, sem conseguir deter a mobilização social, representantes do governo e do campesinato negociaram a liberação de Quispe e outras demandas da CSUTCB. Contudo, apesar do acordo alcançado, em setembro daquele ano, as mobilizações no Altiplano de La Paz recomeçaram.

\footnotetext{
${ }^{78}$ Raquel Gutiérrez Aguilar sublinha o trabalho de Felipe Quispe e outras autoridades camponesas de difusão, em diferentes comunidades do Altiplano de La Paz, de informação sobre a Lei de Águas. A partir desse trabalho de base, Quispe teria nutrido um grupo de militantes em torno de si. Esses seriam precedentes da insurreição no Altiplano de La Paz a ter em conta (2008: 106).

${ }^{79}$ Para a descrição desses eventos no Altiplano foram consultados Assies e Salman (2005), García Linera et al (2008 [2004]), Gutiérrez Aguilar (2008), Iamamoto (2008).
} 
Omasuyus foi o cenário central da revolta organizada pela CSUTCB. Nessa região não nasceu apenas Felipe Quispe, mas também o primeiro Quartel General Indígena pós-Revolução de 52, o Quartel de Q“alachaca. García Linera et al. indicam que na província de Achacachi, cinquenta mil aymaras e quéchuas reuniram-se por mais de vinte dias, numa grande assembleia (2008 [2004]: 146). Como explica Iamamoto:

Logo atrás da pequena ponte que marca a entrada da cidade de Achacachi há uma montanha. Este era um dos pontos de bloqueio estratégicos da região de Omasuyus e os camponeses o mantinham através de turnos feitos pelas comunidades. Os bloqueadores se reuniam nesta montanha e ali faziam assembleias, discussões, planejavam táticas e se preparavam para o enfrentamento [...] Mas o quartel, obviamente, não era somente um espaço de discussão política, era principalmente um espaço de resistência, no qual as pessoas portavam armas, dispostas a um enfrentamento intenso (2008: 148).

Felipe Quispe explica os eventos daquele ano:

A bandeira tricolor [boliviana] já não servia. Os monumentos tinham que ser destruídos. Destruímos alguns monumentos [...] A polícia já não controlava, nós tínhamos a polícia sindical. Já não havia ladrões. A justiça a fazíamos nós mesmos, através do direito indígena, ou justiça comunitária [...] O poder estava nascendo, desde baixo, do chão ${ }^{80}$.

Em outubro de 2000, setores urbanos de El Alto e outros municípios na periferia de La Paz aderiram à mobilização. Quispe e as lideranças da CSUTCB reeditaram o discurso da existência de duas Bolívias, articulado pelo intelectual indianista Fausto Reinaga (1906-1994) ${ }^{81}$ e, em um momento de construção de uma autonomia de factoradical, articulou-se um discurso sobre a Nação Aymara ${ }^{82}$.

\footnotetext{
${ }^{80}$ Entrevista realizada em La Paz, dezembro de 2013.

${ }^{81}$ Nas II Jornadas Andino-Americanas realizadas em 2006, em La Paz, Felipe Quispe explicava: "Nossos antepassados como Julián Apaza (Tupak Katari), José Cabriel Condorcanqui (Tupak Amaru) e outros grandes lutadores pensaram a luta de nações: duas nações, duas repúblicas. A república índia frente à república espanhola. E essa luta era para alcançar a autodeterminação dos povos e nações indígenas. Por isso que esse pensamento filosófico se encarnou em nós, em seus filhos que estamos lutando e nos
} 
Após acordos com o governo, houve um momento de trégua da insurreição camponesa, que durou de outubro de 2000 a junho de 2001. Nesse período, Quispe fundou o partido Movimiento Indígena Pachakuti (MIP) e, em meio a uma disputa com a parcela da CSUTCB que apoiava Evo Morales, foi elaborado o Manifesto de Achacachi. O documento, aprovado no Congresso de Unidade da CSUTCB convocado por Quispe em abril de 2001, afirmava que havia chegado a hora de serem respeitado os "direitos milenários à autodeterminação e à autonomia de nossas Nações originárias" (citado em Gutiérrez, 2008: 131, tradução minha).

Quando foram retomadas as mobilizações, em junho de 2001, articulou-se uma aliança, o Pacto Intersindical, entre o campesinato liderado por Quispe e sindicatos de professores rurais, de motoristas (transportistas) e de pequenos comerciantes (gremiales) (Gutiérrez, 2008: 136). Dentre as demandas apresentadas ao governo naquele ano estavam: a anulação do Decreto Supremo 21060 de 1985 (conhecido como o marco inicial da implantação de medidas econômicas e políticas neoliberais na Bolívia); a substituição de heróis nacionais de origem europeia por outros de origem indígena; e, autogoverno indígena (García Linera et al., 2008 [2004]: 181).

O Quartel General de Q Qealachaka foi rearticulado, assim como outros quartéis indígenas, em distintas províncias do Altiplano ayamara.

O resultado da insurreição popular no Altiplano de La Paz foi a construção de uma autonomia radical, a partir da expulsão de autoridades governamentais e da organização da ordem política e social em desconhecimento do Estado, como explica

consideramos como continuadores desses grandes homens. Por isso é que tem havido mobilizações em nosso país, mas isso não é recente, vem desde 1781 e 1783 [...]" (Gutiérrez, Escárzaga (coord.), 2007: 55, tradução minha).

${ }^{82}$ Neste mesmo evento, Eugênio Rojas, importante dirigente camponês da região de Omasuyus, que participou ativamente das mobilizações na região, afirmava: "Nós somos esse povo, a nação aymara que viveu por anos e por isso nossos levantes de 2000 e desde muito antes" (ibid.: 60, tradução minha). 
Quispe na entrevista supracitada. Ademais, as mobilizações marcaram o ressurgimento da central camponesa CSUTCB como uma das principais forças políticas da Bolívia.

\subsection{O movimento cocaleiro}

Ao mesmo tempo em que, no Altiplano, camponeses organizados na CSUTCB bloqueavam estradas e questionavam a legitimidade do Estado boliviano, ao expulsar seus representantes e enfrentar seu exército; na região do Chapare, departamento de Cochabamba, outro setor do campesinato também havia se levantado contra o governo nacional ${ }^{83}$. Esse levante estava relacionado à estratégia adotada pelos governos de Hugo Banzer (1997-2001) e de Tuto Quiroga Santa Cruz (2001-2002) de eliminação da produção da folha de coca na Bolívia. A chamada política de "coca zero" foi posta em prática apoiada por uma grande violência estatal.

A produção de folha de coca na Bolívia se concentra nas regiões do Chapare, em Cochabamba, e dos Yungas, nas terras baixas do departamento de La Paz. Os Yungas são uma região de chamado cultivo de coca tradicional, destinado ao consumo interno. Aqui vive a grande maioria da população afrodescendente boliviana que, durante a época colonial, era obrigada a trabalhar na produção de folhas de coca que eram consumidas nas minas do país. No Chapare, os plantadores de coca haviam formado ao longo dos últimos anos uma forte rede de sindicatos locais, parte filiada à CSUTCB e outra à Confederación Sindical de Colonizadores de Bolivia $(\mathrm{CSCB})^{84}$. Trata-se do que

\footnotetext{
${ }^{83}$ O Chapare é uma província localizada norte do departamento de Cochabamba, numa região de vales, região de transição entre os Andes e a Amazônia.

84 Atualmente chamada de Confederación Sindical de Comunidades Interculturales de Bolivia (CSCIOB). A mudança no nome da organização pode ser entendida a partir das seguintes explicações disponíveis em seu sítio na internet: "Somos aymaras, quéchuas, guaranis e de outros povos originários que imigramos dos altos cumes dos Andes às zonas subtropicais em busca de melhores condições de vida. A razão foi a falta de terra, os desastres naturais e a poluição causada pelas empresas agroindustriais. Muitos migramos a zonas urbanas em busca de trabalho mas, frequentemente, encontramos discriminação e exploração. Na década de 60, o governo junto com a Aliança para o Progresso, programa do governo
} 
se identifica na Bolívia como uma região de colonização, ou seja, uma área que historicamente tinha uma baixa densidade demográfica, devido à pequena população indígena local, e que foi povoada por migrantes ${ }^{85}$. Esse fluxo migratório se expandiu na década de 1970, ao mesmo tempo em que crescia o cultivo da coca, que tem a grande vantagem de permitir várias safras anuais ${ }^{86}$. A partir de 1985, chegaram ao Chapare novos "colonizadores", trabalhadores das minas que haviam sido demitidos em massa e camponeses de outras regiões do país ${ }^{87}$.

A estratégia adotada pelo governo boliviano a partir de meados da década de 1980 foi erradicar o que era considerado produção excedente de coca, que seria destinada à produção de cocaína e não ao uso tradicional no mercado interno. Foram adotados programas de erradicação voluntária dos cultivos de coca em troca de indenizações. Paralelamente, desenvolveu-se o aparato repressivo estatal no Chapare, com a ajuda militar estadunidense. Os Estados Unidos, além de fornecer helicópteros, aviões e armamento também treinava os militares bolivianos.

O governo dos Estados Unidos teve grande influência na enorme violência desencadeada pela repressão aos plantadores de coca, principalmente na região do Chapare. A influência estadunidense na política interna boliviana de erradicação da coca

estadunidense, com a finalidade de frear a migração urbana, organizaram assentamentos humanos nas zonas tropicais do país, programa chamado colonização. Ignorando que somos povos milenários do que hoje se chama Bolívia, desde então nos chamam colonizadores. A CSCIOB é a organização matriz dos Reconstituídos Povos Originários da Bolívia, erroneamente chamados colonizadores, que luta pela autodeterminação das nações originárias do Kollasuyo e da Amazônia. A CSCIOB é uma organização revolucionária que busca a unidade dos setores marginais para mudar o sistema neoliberal por outro mais justo, equitativo e solidário. Sem excluídos, oprimidos nem explorados" (tradução minha). Fonte: http://www.cscbbol.org/node/14, consultado em 03/03/2014.

85 As explicações aqui apresentadas sobre a colonização do Chapare, a organização de plantadores de coca e as ações governamentais na região encontram-se em Urquidi, 2007; García Linera et al., 2008 [2004]; Gutiérrez, 2008.

86 García Linera et al. chamam a atenção para o fato dos camponeses do Chapare não serem monocultores, sendo assim, além de plantar coca, outros produtos são cultivados para o autoconsumo e para a venda no mercado (2008 [2004]: 385).

87 Evo Morales nasceu na comunidade de Orinoca, departamento de Oruro, filho de pais aymara e quéchua. Desde pequeno, pastor de lhamas, migrou no começo da década de 1980 com sua família para o Chapare, em função de grandes perdas no rebanho em sua região causadas por mudanças climáticas. Trata-se de uma trajetória comum entre vários camponeses indígenas conhecidos como colonizadores. Para a biografia de Evo Morales e os seus primeiros anos no governo, ver Sivak, 2008. 
não era recente: os governos de Paz Zamora (1989-1993) e Sanchéz de Lozada (19931997) já haviam sido pressionados pelos Estados Unidos para erradicarem a produção de folha de coca. Se, anos antes, a "ameaça comunista" já havia sido substituída pela ameaça da produção e do comércio de drogas como justificativa para a intervenção militar e econômica estadunidense na América Latina (Pannain, 2008: 69); a partir de 2000, essa estratégia imperialista se intensifica. Entre os anos fiscais de 2000 e 2007, a média orçamentária anual para os programas estadunidenses de combate aos narcóticos na América Latina e Caribe ultrapassou 800 milhões de dólares. Na década anterior, a média era de 134 milhões de dólares anuais (Cook et al., 2007 apud Pannain, 2008: 75). Como explica Sivak, no Chapare, “,Causachun coca! Wañuchun yanquis!e (Viva a coca! Morram os ianques!) se transformou em grito de guerra. $\mathrm{O}$ mesmo grito de Morales, diante da imprensa, na noite de 18 de dezembro de 2005 quando soube que tinha recebido mais de 50\% dos votos" (2008: 68, tradução minha).

A repressão governamental se intensificou a partir do governo constitucional de Hugo Banzer, quando as erradicações dos cultivos de coca deixam de ser opcionais para os produtores. O objetivo era eliminar totalmente a produção de folha de coca no país. Dessa forma, a violência estatal, que já havia levado à tortura e ao assassinato de inúmeros camponeses na região, aliada à ameaça ao sistema tradicional de uso da água, colocou o movimento cocaleiro no centro da crise política em seus primeiros anos. Assim, além da importante participação dessa parcela do campesinato cochabambino durante a guerra da água, os produtores de coca, principalmente do Chapare, utilizaram naqueles anos seus sistemas de organização relativamente autônomos para enfrentar as ações violentas do Estado boliviano na região.

Tal como ocorreu no Altiplano, no período de crise política iniciado no ano de 2000, a existência de formas de organização social, política e econômicas relativamente 
autônomas ao Estado foi central na revolta e resistência levadas a cabo pelos cocaleiros do Chapare. Há cinquenta anos, o campesinato local, por meio do sindicato, era responsável pela organização social, política e econômica da região, através da aplicação da justiça comunitária; manutenção de edifícios comuns, como escolas; regulação do mercado de terras; construção de infraestrutura; e, demais questões da vida cotidiana das comunidades ${ }^{88}$. Progressivamente, a organização sindical local se tornou fundamental na defesa contra as ações repressivas do Estado boliviano e de representantes estadunidenses. Pablo Mamani assinala a existência de "verdadeiros governos cocaleiros”. Em acordo com Mamani, Raquel Gutiérrez afirma:

Não é exagero apontar que os sindicatos de base do Chapare constituíram desde seu início a principal autoridade civil da zona, praticando uma autonomia de facto; em confronto permanente com as autoridades militares e policiais que implantavam as decisões tomadas pelo governo central em relação à "guerra contra a produção de coca" (2008: 167, tradução minha).

A partir da década de 1990, comitês de autodefesa haviam sido criados para evitar a destruição das plantações de coca, levando a enfrentamentos constantes com as forças repressivas estatais. Os bloqueios de estradas, que já faziam parte do repertório de ação coletiva do movimento, organizados de forma recorrente, foram fundamentais durante a guerra da água. Sobre os repertórios de ação coletiva do movimento cocaleiro, Stefanoni sublinha que "os bloqueios de caminhos [...] e a confrontação com forças policiais e militares de erradicação resultaram em poderosas demonstrações de força e capacidade de mobilização que desafiam o princípio de autoridade e soberania estatal"

\footnotetext{
${ }^{88}$ À imagem do que ocorre nas comunidades indígenas andinas, a posse da terra na região do Chapare implica em deveres com a comunidade, através da participação em assembleias, do trabalho comunitário, da ocupação de cargos dentro do sindicato etc. García Linera et al. afirmam, entretanto, que o tipo de sindicalismo criado no Chapare resultava de uma combinação entre o "habitus sindical e comunal de cada família" e o fato de ser "uma associação de proprietários individuais que se associam a partir de sua propriedade e da defesa de sua propriedade" (2008 [2004]: 395, tradução minha).
} 
(2003: 58, tradução minha). Para o autor, as marchas seriam um "recurso desesperado de revelação do grupo social", que busca a solidariedade de outros setores através do sacrifício do próprio corpo além de uma "solidariedade político ideológica por meio da interpelação discursiva" (ibid.: 58-9) ${ }^{89}$.

Em setembro de 2000, os plantadores de coca voltaram a se mobilizar e dez mil camponeses bloquearam a importante estrada que liga Cochabamba a Santa Cruz, em defesa da legalização do cultivo de uma determinada quantidade (1/4 de hectare) de coca por família, por um desenvolvimento alternativo, e, igualmente, contra a construção, anunciada pela embaixada estadunidense, de um novo quartel militar na região (García Linera et al, 2008 [2004]: 404) ${ }^{90}$. O governo do ex-ditador Hugo Banzer enviou mais tropas para reprimir os camponeses mobilizados. Contudo, em outubro, um acordo foi assinado com o governo.

O acordo não cessou a mobilização dos cocaleiros e, em abril de 2001, os plantadores de coca dos Yungas se aliaram às organizações do Chapare contra o projeto de erradicação total da coca. Duas colunas foram organizadas em direção à La Paz a partir de cada região produtora de coca. À coluna de Cochabamba, aliaram-se outros atores sociais organizados, como professores rurais.

A partir da pressão dos camponeses, novas negociações com o governo foram agendadas. No entanto, quando Jorge Quiroga assumiu a Presidência devido ao débil estado de saúde de Hugo Banzer, reiniciou-se a mobilização cocaleira. Essa mobilização respondia não apenas à política de erradicação, mas, era igualmente uma resposta ao assassinato de um líder sindical pelo exército.

\footnotetext{
${ }^{89}$ Cabe ressaltar que a marcha, assim como a greve de fome, fazem parte do repertório de ação coletiva de diferentes movimentos sociais bolivianos.

${ }^{90}$ Sobre a questão dos cultivos alternativos, Iamamoto (2011) explica que havia uma frustração por parte dos camponeses do Chapare com a falta de mercado para esses produtos, outro problema apontado pela autora são os altos investimentos e as grandes superfícies de terra necessárias para os "cultivos alternativos", quando comparados à produção de folha de coca.
} 
Apesar das disputas pelo controle da CSUTCB, entre Felipe Quispe e Evo Morales, naquele momento presidente das Seis Federações do Trópico Cochabambino, o primeiro apoiará o movimento cocaleiro quando este será fortemente reprimido pelo governo de Quiroga. Como narram Assies e Salman:

Alguns dias depois, Quispe, Evo Morales, o líder da Comunal ${ }^{91}$ Oscar Olivera e o líder cocaleiro da região de Yungas, Dionisio Nuñez, foram fotografados felizes em um aperto de mãos depois de terem concluído um pacto de apoio mútuo contra o neoliberalismo (2005: 282, tradução minha).

Em 2002, quando começou a implantação do Decreto Supremo 26415, de novembro de 2001, que "proibia a secagem, transporte e venda de coca produzida no Chapare" (García Linera et al., 2008 [2004]: 410, tradução minha) ${ }^{92}$, foram organizados novos bloqueios e ocorreram novos enfrentamentos entre os cocaleiros e o governo de Tuto Quiroga. Naquele momento, o setor do campesinato do Altiplano mobilizado sob a liderança de Quispe se juntou aos cocaleiros na demanda de anulação do referido decreto $^{93}$. Pela primeira vez, os ayllus aymaras do Sul de Oruro, através do Consejo Nacional de Ayllus y Markas del Qullasuyu (Conamaq), participaram da mobilização (Albó, 2009: 171). Essa, entretanto, foi interrompida quando o governo aceitou suspender temporariamente a aplicação do decreto.

As duas regiões de plantação de coca, o Trópico de Cochabamba e os Yungas em La Paz, estavam mobilizados entre 2000 e 2001. O Consejo de Federaciones Campesinas de los Yungas (Cofecay) havia organizado diversas marchas na década de 1990, algumas em aliança com o movimento cocaleiro do Chapare. Com o plano de

\footnotetext{
${ }^{91}$ Comunal: Coodinadora de Movilización Única Nacional.

${ }^{92}$ Decreto Supremo 26415, 27 de novembro de 2001, disponível em http://www.lexivox.org/norms/BODS-26415.xhtml, consultado em 29 de abril de 2014.

${ }^{93}$ Outro evento que desencadeou a mobilização do movimento cocaleiro do Chapare em 2002 foi a expulsão de Evo Morales do Congresso Boliviano.
} 
Banzer de erradicação total do cultivo da coca no país, os Yungas, à imagem do que estava ocorrendo no Chapare há alguns anos, foi militarizado. A consequência foi o fortalecimento da organização sindical e o crescimento da mobilização contra as políticas estatais. Contudo, o movimento cocaleiro dos Yungas teve pouco impacto no cenário político nacional quando comparado à Coordinadora de las Seis Federaciones del Trópico de Cochabamba, da qual Evo Morales é Secretário Geral desde 1988. Foi igualmente do movimento cocaleiro do Chapare que surgiu o projeto para a constituição de um "instrumento político" que permitisse a participação do movimento em eleições, dando origem ao Instrumento Político porla Soberanía de los Pueblos (IPSP) ${ }^{94}$.

Para os que observam a Bolívia de um ponto de vista externo, é preciso ter em mente que a folha de coca é usada pelos povos originários desde antes da invasão espanhola, quando era empregada em rituais religiosos e em atividades cotidianas. A folha da coca é consumida atualmente em várias regiões da Bolívia e de países vizinhos. $\mathrm{O}$ ato de mascar a folha de coca (acullicar ou pijchar, como se diz no Altiplano, ou bolear, como dizem os chaqueños), ou sua ingestão através de chás, combate os efeitos colaterais da grande altitude, na qual vive parte dos bolivianos, combate a sensação de fome, funciona como um estimulante, como a cafeína, além de ser um importante meio de socialização entre pessoas. A coca continua sendo usada em rituais religiosos no Ocidente boliviano, como quando se ch'alla uma casa, um negócio ou um carro, ou, como é praticado pelo presidente Evo Morales, quando se ch'alla escritórios governamentais ou são inauguradas obras públicas. A ch'alla é um ritual de proteção no qual se oferece à Pachamama (Mãe Terra) diferentes alimentos e bebidas, em troca de proteção.

\footnotetext{
${ }^{94}$ Sobre o IPSP, ver Capítulo 1.
} 
Ainda que a origem desse ritual esteja associada usualmente com as populações indígenas do Ocidente, durante meu trabalho de campo, em uma visita a um território indígena no Chaco, para entramos em uma área de floresta, foi realizado um rápido ritual em guarani no qual foram oferecidas folhas de coca e foi pedida proteção para os visitantes. Outro fator importante para ter em mente é o fato do cultivo da folha de coca na região do Chapare ser mais lucrativo do que a maioria dos produtos agrícolas. Não se trata de um fator de pouca relevância quando consideramos a "explosão da miséria nas áreas rurais e urbanas, o aprofundamento da crise social e a recessão econômica produzidos pelas reformas estruturais", dos quais nos lembra Urquidi (2007: 33). Como afirma a autora, "o movimento cocaleiro é o elo mais frágil da cadeia que produz um subproduto utilizado também pela indústria ilícita de drogas, e como tal, é igualmente vítima da exploração econômica e moral do comércio ilegal da cocaína” (2011: 9). São camponeses cuja média da propriedade atualmente é de 10 hectares por família na região do Chapare (García Linera et al., 2008 [2004]: 385).

Essas breves explicações são importantes para entendermos a permeabilidade da sociedade civil boliviana ao discurso do movimento cocaleiro em torno da defesa da "folha sagrada da coca" e contra a ingerência estadunidense na política nacional. Sendo Evo Morales presidente da principal confederação de plantadores de coca, esses dois discursos tiveram grande destaque na sua eleição e durante o seu governo, como apresentarei mais adiante.

Gutiérrez afirma que, ao travarem uma "luta de resistência", a prioridade dos cocaleiros era fortalecer sua coesão interna e, ao mesmo tempo, tecer vínculos com outros segmentos sociais, com a sua sensibilização a respeito da importância da produção da folha de coca. O surgimento do MAS-IPSP, conclui a autora, deve ser entendido tendo em conta essa característica do movimento cocaleiro (2008: 167). A 
autora sublinha, contudo, que a construção de um partido político a partir do movimento cocaleiro não é consequência de um "esforço ideológico e organizativo sistemático e disciplinarmente construído"; a participação eleitoral seria mais uma forma de resistência “à contínua investida anticoca dos sucessivos governos” (ibid.: 173).

O destaque que ganharia o partido político criado a partir do movimento cocaleiro, quando comparado ao MIP de Felipe Quispe, pode ser entendido, pelo menos em parte, pelo enfoque dado ao movimento liderado por Quispe na distinção entre q'aras (brancos, não indígenas) e indígenas e pela ausência de uma caracterização étnica do opositor por parte do movimento cocaleiro, de que falam García Linera et al. (2008 [2004]: 443). Esta característica dos cocaleiros se deve em parte à "raiz cultural mestiça" do movimento camponês de Cochabamba de que nos fala Silvia Rivera (2003 [1984]) e à grande influência no movimento cocaleiro dos antigos mineiros que haviam migrado para o Chapare a partir de 1985.

Sobre a característica do MAS apontada, Pablo Stafanoni afirma:

Frente às polarizadas visões acerca de como "mudar o mundo", o MAS-IPSP pleiteia sem fissuras a necessidade de transformar o poder conquistado pelas organizações sociais em poder estatal; no contexto do novo ciclo de lutas e transformações da estrutura de oportunidades políticas em benefício da ação coletiva de setores subalternos (2003: 66, tradução minha).

A consequência, sem dúvida, foi a expansão do sucesso eleitoral do IPSP-MAS de Cochabamba para os outros departamentos do país nas eleições de 2002 e a vitória de Evo Morales três anos mais tarde. Mas essa foi igualmente resultado da expansão da mobilização social, envolvendo organizações representantes de diferentes povos indígenas. 


\subsection{A Marcha Indígena pela Assembleia Constituinte}

A demanda das organizações indígenas das terras baixas pela instauração de uma Assembleia Constituinte ganhou força quando, em 2000, a Coordenadora em Defesa da Água e da Vida adotou a reivindicação. Dois anos depois da guerra da água, povos indígenas das terras baixas e altas organizam a Marcha pela Assembleia Constituinte, batizada de "Marcha pela Soberania Popular, pelo Território e pelos Recursos Naturais". Foi a quarta marcha organizada pelas organizações indígenas das terras baixas desde a famosa "Marcha pelo Território e Dignidade" de 1990. Todas as marchas até então levavam em seu nome a defesa do território, principal reivindicação dos indígenas das terras baixas nas últimas décadas. Em 1996, durante o debate da Lei Inra, fora realizada a "Marcha pelo Território, Terra, Direitos Políticos e Desenvolvimento", mencionada no capítulo anterior. Quatro anos mais tarde, no mesmo ano em que ocorria a guerra da água, o tema dos recursos naturais foi central na marcha liderada pela Coordinadora de Pueblos Étnicos de Santa Cruz (CPESC), a "Marcha pela Terra, pelo Território e pelos Recursos Naturais".

No entanto, na marcha de 2002, pela primeira vez, falava-se em "soberania popular". Os indígenas não apenas reivindicavam que o Estado reconhecesse seus direitos, mas exigiam a participação no Estado, ou mais especificamente, na redefinição do Estado.

É preciso ter em mente a grande dimensão do território boliviano para imaginarmos o que significam as marchas organizadas pelos povos indígenas das terras baixas, que cruzam centenas de quilômetros, durante muitas semanas, para chegar a La Paz. Por um lado, o espaço e o tempo percorridos implicam em um enorme esforço por parte dos participantes e a necessidade de apoio e logística, para alimentar e alojar 
centenas ou milhares de pessoas, por outro lado, ao cruzar o território nacional, novos aliados se engajam na mobilização.

A respeito da IV Marcha, o antropólogo Xavier Albó especula sobre o contato entre organizações indígenas das terras baixas e de outros países do continente como uma possível explicação para aquelas defenderem a criação de uma Assembleia Constituinte, tendo em vista os avanços, em termos de reconhecimento de direitos dos povos indígenas, decorrentes das novas constituições elaboradas no Brasil, Colômbia, Equador e Venezuela (2009: 171-2).

A IV Marcha foi organizada pelo "Bloco Oriente", uma aliança formada por organizações indígenas, camponesas, de colonizadores e sem terras. Dentre as primeiras, destaca-se a Coordinadora de Pueblos Étnicos de Santa Cruz (CPESC), uma integrante da Confederación de Pueblos Indígenas de Bolivia (Cidob), que se tornaria autônoma em relação à organização matriz naquele mesmo ano.

Em março de 2002, organizações indígenas e camponesas se reuniram em La $\mathrm{Paz}^{95}$. Naquele momento, as organizações assinalaram a existência de uma crise generalizada no país. Para as organizações sociais presentes, a solução dessa crise implicaria em mudanças estruturais.

Em um novo encontro realizado um mês mais tarde, as organizações sociais denunciaram o chamado "pacote agrário", que o governo tentava aprovar. Dentre os inúmeros problemas nesse projeto expostos no documento elaborado no encontro, constava a revisão na lei que aumentava a extensão de terra que poderia ser destinada por cada animal para que uma propriedade fosse considerada produtiva. As organizações anunciaram bloqueios de caminhos e das campanhas para as eleições que

\footnotetext{
${ }^{95}$ As informações sobre a IV Marcha e seus preparativos apresentadas aqui se encontram no detalhado estudo de Carlos Romero Bonifaz (2005), que participou da mobilização como assessor das organizações indígenas.
} 
seriam realizadas em junho. Foram então se consolidando alianças entre distintos atores que participariam da IV Marcha, iniciada por 500 representantes das organizações sociais, no dia 13 de maio.

A marcha denunciava o projeto de lei que ambicionava limitar a participação da maioria dos bolivianos nos debates em torno da nova constituição a ser elaborada. Exigia-se a convocação de uma Assembleia Constituinte na qual a participação dos diferentes setores sociais não estivesse necessariamente mediada pelos partidos políticos. Ademais, os manifestantes reivindicavam a anulação das medidas do "pacote agrário" que beneficiavam os grandes proprietários de terras.

No dia seguinte à saída da marcha da cidade de Santa Cruz em direção a La Paz, o número de participantes já havia dobrado. À medida que a marcha avançava, novas organizações indígenas da Amazônia, de camponeses e de colonizadores foram se incorporando. Dez dias depois de iniciada a marcha, representantes de ayllus dos departamentos de Chuquisaca e Potosí, parte do Consejo Nacional de Ayllus y Markas del Qullasuyu (Conamaq), iniciaram outra marcha, com a mesma reivindicação, e que deveria unir-se à mobilização que havia partido de Santa Cruz.

Apesar do apoio de diferentes organizações sociais do departamento de Cochabamba, quando passou pelo Chapare, a IV Marcha não recebeu a esperada adesão dos cocaleiros.

Chegando a Cochabamba, o grupo das terras baixas recebeu o apoio da Coordenadora pela Defesa da Água e da Vida, e de Oscar Olivera; e perdeu o apoio do líder do Movimiento sin Tierra (MST), que assinou um acordo com o governo e abandonou a marcha. As bases do MST, no entanto, seguiram na mobilização. A deserção fazia parte da estratégia adotada pelo governo de Quiroga para enfraquecer a mobilização. Em diferentes momentos da marcha foram enviados ministros e outros 
representantes do governo central para negociar com os dirigentes. Romero Bonifaz relata inclusive uma disfarçada tentativa de suborno ${ }^{96}$.

Com as tentativas frustradas de desmobilizar a marcha através da cooptação de suas lideranças, o governo adotou outra estratégia: negociar de forma paralela com a confederação das organizações das terras baixas, a Cidob, que não participava da marcha. O governo formou, então, uma Cúpula Político-Social com os partidos políticos e representantes das Cidob, para a elaboração de um acordo que esvaziasse a IV Marcha. Ao lado de Marcial Fabricano, presidente da Cidob, assinaram o acordo outros representantes de suas organizações regionais, como a Asamblea del Pueblo Guaraní (APG). O acordo foi evidentemente rejeitado pelos organizadores da marcha do Bloco Oriente e por autoridades do Conamaq. É interessante notar que o líder da Cidob que havia negociado com o governo de Tuto Quiroga, Marcial Fabricano, tornou-se, dois meses mais tarde, o Ministro de Assuntos Indígenas de Gonzalo Sánchez de Lozada, eleito presidente em agosto de 2002.

No dia 13 de junho, no departamento de Oruro, a marcha organizada pelo Bloco Oriente, que naquele momento tinha aproximadamente duas mil pessoas, uniu-se aos cinco mil indígenas das Terras Altas que marchavam sob a liderança do Conamaq. Romero Bonifaz aponta as dificuldades no diálogo para a elaboração de uma pauta comum de reivindicações entre o Bloco Oriente e o Conamaq (ibid.: 123). Em um ponto, entretanto, os dois grupos teriam grande afinidade: o projeto de decreto sobre o direito à consulta dos povos indígenas quando suas terras são afetadas por projetos econômicos.

\footnotetext{
${ }^{96} \mathrm{O}$ Centro de Estudos Jurídicos e Investigação Social (Cejis) foi acusado pelo governo de manipular a mobilização. O Cejis é uma importante organização não governamental que trabalha com a temática indígena. Na época da marcha, Romero Bonifaz trabalhava para o Cejis, e é a instituição que editou o livro aqui usado como referência para os acontecimentos da IV Marcha.
} 
Ao passar por El Alto, no dia 18 de junho, a marcha recebeu um apoio massivo da população da cidade. Nenhuma das propostas de acordo do governo respondia satisfatoriamente às reivindicações da marcha, que chegou finalmente à La Paz, depois de mais de $800 \mathrm{~km}$ percorridos desde Santa Cruz.

No dia 21 de junho de 2002, dirigentes da marcha se reuniram no Parlamento com delegados dos partidos políticos e ministros. Foi, então, assinado um acordo nacional pela Assembleia Constituinte.

O governo, que havia fracassado em sua tentativa de esvaziar a mobilização social, vira-se então obrigado a negociar com os representantes das organizações que haviam caminhado centenas de quilômetros até a La Paz. Assim, além do Conamaq, do MST e de organizações indígenas do Oriente, assinaram o acordo do dia 21 as federações de camponeses de Potosí, Santa Cruz e Pando, as Bartolinas (Confederación Nacional de Mujeres Campesinas Indígenas Originarias de Bolivia "Bartolina Sisa" CNMCIOB "BS"), a Confederación Sindical de Colonizadores de Bolivia (CSCB), dentre outras organizações. Embora Romero Bonifaz sublinhe que tal acordo não respondia a todas as demandas das organizações, ele representava um avanço em relação ao acordo anterior firmado com as organizações indígenas que não participavam da marcha.

A mobilização indígena havia sido bem sucedida e, desde então, a instauração de uma Assembleia Constituinte passou a ter grande importância no debate político nacional.

Por um lado, a Marcha pela Assembleia Constituinte foi uma base importante para a elaboração futura de reivindicações e, por outro, foi o resultado de articulações e debates anteriores dentro do movimento indígena. 
A marcha indígena de 2002 está inscrita em um contexto de crescente mobilização social e seguidas derrotas dos governos nacionais, como foi o caso da suspensão da Lei de Águas, da liberação de Felipe Quispe e da convocação de uma Assembleia Constituinte, que iria contra o projeto governamental de levar a cabo reformas políticas a partir do Parlamento e do Executivo, ou seja, sem uma abertura para a participação dos setores subalternos mobilizados. É nesse momento que são realizadas as eleições presidenciais e para deputados e senadores, em 30 de junho de 2002. Mostro a seguir como essas eleições apresentam um resultado inédito que apontava para a ruptura da ordem política institucional vigente.

\subsection{Mobilização popular, repressão estatal e fuga de umpresidente}

Em 2002, quando o modelo econômico e político ao qual estava associado Gonzalo Sánchez de Lozada, o "Goni”, já demonstrava importantes sinais de crise, esse foi eleito presidente com uma pequena margem de votos. Goni (MNR) recebeu apenas 22,46\% dos votos, contra 20,94\% de Evo Morales (MAS-IPSP), 20,91\% de Manfred Reyes Villa (NFR), 16,31\% de Jaime Paz Zamora (MIR) e 6,1\% de Felipe Quispe $(\mathrm{MIP})^{97}$. Naquela época não havia segundo turno para as eleições presidenciais na Bolívia, cabendo ao Parlamento escolher o presidente dentre os primeiros candidatos, no caso de nenhum haver alcançado uma votação superior a 50\%. Consequentemente, uma aliança foi formada entre o Movimiento Nacionalista Revolucionario (MNR), de Sanchéz de Lozada, a Nueva Fuerza Republicana (NFR), de Manfred Reyes Villa, e o

\footnotetext{
97 Para os resultados das eleições presidenciais de 2002, ver: http://pdba.georgetown.edu/Elecdata/Bolivia/pres02.html, consultado em 29/04/2014.

O documentário "Crise é o nosso negócio. Uma história de marketing e política na Bolívia”, de Rachel Boynton, lançado no Brasil em 2007 pela Coleção Videofilmes, acompanha a campanha política de Sanchéz de Lozada, através da consultoria feita por estadunidenses especialistas em campanhas eleitorais em diferentes países. O filme mostra como no começo da campanha, o Goni não apenas não ocupava o primeiro lugar nas pesquisas como tinha um grande índice de rejeição por parte do eleitorado.
} 
Movimiento Izquierda Revolucionaria (MIR) ${ }^{98}$. O MIR era um dos principais partidos da chamada "democracia pactuada", e havia feito acordos com a Acción Democratica Nacionalista (ADN) do general Hugo Banzer, para que este assumisse a presidência em 1997, e, igualmente para garantir a posse como presidente de Jaime Paz Zamora, principal líder do MIR, nas eleições de 1989. No entanto, ao longo das três décadas desde a volta à democracia, o MIR e o MRN nunca haviam participado de uma mesma coalisão de governo ${ }^{99}$. Além dessa aliança inédita, era igualmente necessário o apoio do NFR, de Reyes Villa, principal inimigo de Goni durante a campanha eleitoral de 2002. O NFR fora criado em 1995 e, apesar de ter participado a princípio da aliança de sustentação do governo constitucional de Banzer, não pode ser considerado como um dos principais partidos que manteve em funcionamento a democracia pactuada até então. Estes partidos, o MNR, o MIR e a ADN, nas eleições de 2002, alcançavam juntos apenas $41,16 \%$ dos votos para a presidência do país.

Sanchéz de Lozada assumiu a presidência sem a legitimidade do voto popular majoritário e enfrentando a oposição de setores sociais organizados. Goni havia sido o ministro da economia durante o governo de Paz Estenssoro na década de oitenta, quando foi promulgado o Decreto 21060, considerado o marco inicial das políticas de ajuste estrutural na Bolívia. Igualmente, foi durante o seu mandato de presidente, na década seguinte, que foram implantadas as "reformas neoliberais de segunda geração", com destaque para a privatização de grandes empresas estatais, por meio do programa de "capitalización” que havia eliminado importante fonte de recursos estatais através da privatização do setor dos hidrocarbonetos (Webber, 2005: 38).

\footnotetext{
98 Até os últimos dias da campanha presidencial de 2002, Manfred Reyes era o principal adversário de Sanchéz de Lozada segundo as pesquisas de opinião e, como mostra o documentário de Boynton, o principal alvo de ataques da campanha do MNR era Manfred Reyes.

${ }_{99}$ Para os diferentes pactos entre os partidos políticos no período de 1984 a 2001, ver: Calderón, Gamarra (2004: 7).
} 
A crise política vivida pela Bolívia nos anos anteriores atingiu o ápice em 2003. O clima político se tornou mais tenso em fevereiro daquele ano quando o governo, pressionado pelo Fundo Monetário Internacional, anunciou um novo imposto sobre os salários. A Central Obrera Boliviana e Evo Morales convocaram a população a rebelarse contra a medida.

A polícia nacional, que também seria afetada pelo novo imposto, juntou-se à mobilização e entrou em confronto com o exército, deixando um saldo de 15 mortos, entre policiais e militares, explicitando de forma incontestável a gravidade da crise política. Em El Alto, a sede da prefeitura foi ocupada e, em La Paz, os escritórios dos principais partidos da "democracia pactuada" MNR, MIR, ADN foram queimados, assim como edifícios do governo central. Nos confrontos de fevereiro, 34 pessoas foram mortas.

Segundo Gutiérrez, a partir da discussão sobre o déficit fiscal que seria a justificativa do governo para aumentar os impostos dos trabalhadores assalariados, começou a ser debatido de forma ampla o fato das transnacionais petroleiras pagarem apenas $18 \%$ de impostos sobre todo o gás extraído do país, além de não haver nenhum controle estatal sobre esta quantidade de gás (2008: 199) ${ }^{100}$.

Meses mais tarde, em setembro, a CSUTCB comandada por Felipe Quispe organizou uma marcha partindo dos municípios do Altiplano de La Paz, em direção à sede do governo. A mobilização havia sido organizada pela negociação da lista de demandas de 72 pontos elaborada pela confederação sindical e pela liberação de uma autoridade indígena encarcerada, após o assassinato de suspeitos de roubo, em aparente

\footnotetext{
${ }^{100}$ Essa observação de Gutierréz nos recorda a forma como o estanho era explorado na Bolívia no começo do século XX, apresentada no Capítulo 1.
} 
consenso em sua comunidade, no que seria defendido como aplicação da justiça comunitária $^{101}$.

Após uma marcha até La Paz, que foi reprimimida pelo governo, Quispe iniciou uma greve de fome com outras duas mil pessoas na sede da Rádio San Gabriel, em El Alto. Ao mesmo tempo, bloqueios de estradas foram organizados em diversas províncias do Altiplano e foram rearticulados os quartéis indígenas.

A Rádio San Gabriel possibilitava que as discussões e decisões ali tomadas em assembleia fossem difundidas nas diferentes comunidades aymaras (Gutiérrez, 2008: 202). O fato da greve ter sido organizada em turnos, através dos quais se revezavam membros de uma comunidade e mesmo moradores de El Alto, representando parentes de comunidades rurais, facilitou igualmente a difusão de informação sobre a mobilização (ibid.).

$\mathrm{Na}$ apresentação do seu diário escrito durante a greve de fome, Quispe afirma “,tomar o poder a qualquer preço“e esta era a consigna” (2013: 16). A autoridade da CSUTCB aponta a dificuldade em articular a mobilização nas comunidades devido à oposição do MAS e de Evo Morales (ibid.: 23). No dia 12 de setembro, em seu diário Quispe escreve:

Nossa luta é para que exista uma vida digna em nossas comunidades. Não contamos com energia elétrica, internet, telefone e muito menos temos postos de saúde ou hospitais; seguimos nos curando com ervas naturais e urina humana. Não há estradas e por isso, não se pode levar nossos produtos agrícolas às grandes cidades. Não temos água potável [...] Não temos irrigação nas comunidades; nós que vivemos do cultivo da terra temos que olhar para o céu, dia e noite, esperando que caia chuva e assim refresque a pachamama (e as plantações). Não se conhece a mecanização do agro; queremos máquinas agrícolas nos ayllus e nas comunidades (ibid.: 39, tradução minha).

\footnotetext{
101 "A lista de demanda dos 70 pontos, de certa forma era uma versão ampliada do „Pliego Intersindical de 45 pontos, que ficou na mesa de negociação ao serem levantados os bloqueios de 2001" (Gutiérrez, 2008: 200, tradução minha).
} 
Naquele mesmo mês de setembro, a Central Obrera Boliviana realizou uma marcha de El Alto a La Paz. Os moradores de El Alto haviam organizado igualmente uma importante greve contra uma reforma da tributação municipal.

No entanto, o evento que define a amplidão que iria tomar o levante popular de 2003 foi o ataque do exército aos habitantes de Warisata e Sorata, assassinando cinco pessoas, dentre elas uma menina de oito anos que estava dentro de casa, e ferindo inúmeras outras. A população dessas cidades estava mobilizada, assim como em outras partes do Altiplano, sob a liderança da CSUTCB comandada por Felipe Quispe. O "massacre de Warisata", no dia 20 de setembro de 2003, desencadeou a maior revolta popular da história recente da Bolívia. Com turistas estrangeiros sem poder deixar a cidade de Sorata devido aos bloqueios de estradas, o governo enviara a polícia e o exército para resgatá-los. Naquele mesmo momento, havia uma delegação do governo com dois ministros negociando com os grevistas na Rádio San Gabriel.

Após o massacre de Warisata, a CSUTCB sob a liderança de Quispe declarou “estado de sítio". Segundo anotações no diário publicado por Quispe, no dia 30 desetembro, calculava-se que no Quartel de Qeealachaka havia dez mil mulheres e homens armados (ibid.: 86) ${ }^{102}$. Em diferentes províncias do departamento de La Paz as autoridades estatais haviam sido expulsas e substituídas por autoridades sindicais ou comunais. Na sede da rádio em El Alto, os grevistas eram protegidos por uma "polícia comunitária” e por moradores vizinhos à rádio.

\footnotetext{
${ }^{102}$ Falando sobre a organização do "Exército Indígena Aymara de Achacachi”, Eugênio Rojas, importante dirigente camponês e ex-prefeito de Achacachi afirma que a população havia guardado os armamentos da Guerra do Chaco (1932-1935) e os fuzis de 1952 "quando nossos avós haviam defendido o MNR" (Vale lembrar que o MNR é o mesmo partido de Sánchez de Lozada), "Limpamos essas armas a cada certo tempo e guardamos bem, porque sabemos que a qualquer momento podemos enfrentar qualquer exército, podia ser esse exército liberal" (Gutiérrez, Escárzaga (org.), 2007: 63). A partir de 2003, os comunais da Província de Omasuyos seriam conhecidos como "Ponchos Rojos". Para uma história dos Ponchos Rojos, ver Poma et al., 2008.
} 
Em outubro de 2003, o estopim da revolta popular, liderada principalmente por indígenas, foi o projeto do governo de Sánchez de Lozada de exportar o gás boliviano para os Estados Unidos e México através de um porto chileno. Naquele momento, houve uma união de diferentes setores subalternos em torno da "defesa do gás boliviano".

Havia, sem dúvida, um alto grau de insatisfação dos setores subalternos com a política boliviana naqueles anos, que se refletia em intensas e constantes mobilizações sociais desde 2000. Tais mobilizações vinham rompendo as estruturas de poder que mantinham a estabilidade do sistema político "pactuado e excludente" vigente desde 1985. Completando o cenário político das revoltas de 2003, destacavam-se a fragilidade das alianças partidárias que mantinham o governo central e a debilidade deste governo, tornada evidente no confronto entre policiais e militares em fevereiro daquele ano.

Completando o quadro que explica a revolta de 2003, há dois fatores importantes: a rejeição de parte da população à política de privatização realizada no anterior mandato presidencial de Sánchez de Lozada e o ressentimento histórico dos bolivianos por terem perdido o acesso ao mar para o Chile na Guerra do Pacífico (18791883), que o governo não tomou em conta ao decidir exportar o gás via portos chilenos. A perda do mar, e a necessidade de reconquistá-lo, são temas centrais na construção de uma "identidade boliviana" recente. Sua importância pode ser ilustrada pela presença de um baú com a areia do antigo litoral boliviano na Igreja de São Francisco, no centro de La Paz, ao lado dos restos mortais de diferentes heróis nacionais ${ }^{103}$.

\footnotetext{
${ }^{103}$ Ali, encontravam-se também os restos mortais de Eduardo Abaroa, principal herói boliviano da Guerra do Pacífico. Em março de 2013, no Dia do Mar, seus restos mortais foram transferidos para a Praça que leva seu nome, no bairro de Sopocachi, em uma marcha pela cidade, encabeçada pelo presidente e vicepresidente bolivianos. A amplitude dos desfiles cívico-militares anuais no "Dia do Mar" e a participação da população entoando inúmeros cânticos sobre a necessidade de "recuperar o mar" mostram a importância do tema na Bolívia.
} 
Em outubro de 2003, os habitantes de El Alto tornam-se os principais protagonistas da revolta popular, mas também, as maiores vítimas ${ }^{104}$.

Da cidade de El Alto é possível ver, logo embaixo, La Paz. Sua localização geográfica estratégica havia sido central durante a revolta liderada por Tupac Katari na década de 1780 e seria de novo fundamental em 2003. Formada por uma população migrante do campo, El Alto teve um crescimento populacional exponencial nas últimas décadas. A diferença entre o investimento público em La Paz e El Alto é visível, mesmo quando comparamos os bairros mais pobres que se encontram na parte alta da capital administrativa do país. Da mesma forma que em muitas partes do campo boliviano, a infraestrutura básica e a aplicação da justiça ficam a cargo das organizações territoriais, neste caso, das mais de 500 juntas vecinales de El Alto. Em seu estudo sobre a guerra do gás, Pablo Mamani explica a conversão das práticas habituais da população de El Alto, em estruturas de ação coletiva (2005: 12).

De acordo com o censo realizado em 2001 , mais de $80 \%$ da população da cidade de El Alto se autoidentificava como indígena ${ }^{105}$. Porém, além de ter sido formada por migrantes indígenas do campo, El Alto foi igualmente destino de parte dos mineiros que perderam seus empregos na década de oitenta. Assim, a tradição de mobilização desse grupo teve igualmente influência nas práticas cotidianas e, portanto, nas estruturas de ação coletiva mobilizadas em 2003.

Depois de uma bem-sucedida paralização no dia 2 de outubro, no dia 8, a cidade iniciou uma nova paralização, agora por prazo indefinido, contra o projeto de exportação de gás do governo de Sanchéz de Lozada. Com a escassez de alimentos

\footnotetext{
${ }^{104}$ Mamani recorda que, no ano de 2000, os moradores de El Alto haviam aderido ao levante no Altiplano e no Chapare, que culminara com o saque e o incêndio da sede da prefeitura em 29 de maio, após uma marcha que pedia a criação da Universidade Pública de El Alto (2005: 36).

${ }^{105}$ Como nos recorda Xavier Albó, no senso de 2001, a maioria dos bolivianos que se identificavam como indígenas viviam nas cidades (2009: 135).
} 
devido aos bloqueios de estradas organizados pelos camponeses, a solução encontrada para abastecer a sede do governo foi o envio de comida pela via aérea. Porém, para chegar à La Paz, o abastecimento deveria passar por El Alto, onde fica localizado o aeroporto, e, foi justamente para impedir a passagem de alimentos e combustível e pressionar o governo central, que a população da cidade obstruiu suas ruas, avenidas e pontes. Em assembleias locais, os moradores se organizavam em turnos para manter os bloqueios, formar comitês de segurança, cozinhar refeições comunitárias etc. Mamani explica assim essa organização:

A importância que têm esses governos [microgovernos de bairros] é fundamentalmente porque aí é decidida a forma massiva ou coletiva das ações coletivas mediadas pelas assembleias de emergência e de avaliação como foi o controle dos recursos alimentícios e sanitários. Convertem-se em lugares de decisão multitudinária, e de legitimação das ações e do controle do território da cidade. Em resumo, são os lugares onde surgem as decisões políticas e de tipo "militar" dos vizinhos para se autogovernarem e para se contraporem ao poderio militar do governo de Sanchéz de Lozada (2005: 100, tradução minha).

Os diferentes setores sociais mobilizados em 2003, a princípio com distintas reivindicações, articular-se-ão em torno da bandeira da "defesa do gás" e da exigência de renúncia de Sanchez de Lozada. Em abril havia sido criada a Coordenadora de Defesa do Gás, tendo como porta-voz Oscar Olivera. No dia 19 de setembro, a Coordenadora lançou sua primeira convocatória de mobilização (Gutiérrez, 2008: 20820). Estudantes da Universidade Pública de El Alto (Upea), professores e mineiros da Central Obrera Boliviana já estavam mobilizados. Mais tarde, aderiram à revolta popular o movimento cocaleiro do Chapare, o Movimiento sin Tierra, a Coordenadora pela Água de Cochabamba e setores da classe média. 
O levante popular havia se espalhado pelo país e todas as regiões e setores sociais que desde 2000 vinham protagonizando mobilizações uniram-se à luta contra o governo de Sanchéz de Lozada. A Asamblea del Pueblo Guaraní (APG) e membros de outros povos indígenas das terras baixas iniciaram uma greve de fome (Hyton e Thomson, 2005: 57). Estradas estavam bloqueadas por camponeses em Cochabamba e comunidades indígenas fecharam todas as estradas do departamento de Potosí (ibid.: 55). Greves gerais foram declaradas em importantes cidades. Na Praça de São Francisco, localizada no centro de La Paz, na parte conhecida como "cidade dos índios" na época colonial, algumas centenas de milhares de pessoas se reuniam. Nos últimos dias da insurgência popular, setores da classe média iniciaram uma greve de fome pedindo a renúncia do presidente boliviano.

Pablo Mamani sublinha o caráter, ao mesmo tempo, indígena e popular, urbano e rural do levante de 2003 (2005: 56). Para o autor, a percepção de compartilhar uma realidade comum com os camponeses indígenas mobilizados no Altiplano, a partir da "discriminação econômica, social, cultural e política" vivida, é muitas vezes mais perceptível ao povo mobilizado de El Alto do que uma "explícita consciência étnica" (ibid.: 52).

Raúl Prada afirma que os dirigentes dos movimentos sociais passaram a frear as iniciativas sociais. Consequentemente, entre fevereiro e outubro de 2003, teria emergido "a forma organizada da multidão", mostrando "um novo perfil do movimento social" (2003: 39). El Alto passou a ser a "cidade que contem a nação", condensando a história da Bolívia e as demandas dos movimentos sociais; e o indígena, "o eixo articulador de um amplo movimento social e de uma luta de libertação nacional" (ibid.: 41-2, tradução minha). Para Prada, a defesa do gás, entendida como resistência à globalização e ao neoliberalismo; como defesa da soberania nacional; como recuperação do recurso 
natural e a luta pelo excedente; como luta de classes; e, finalmente, a partir das reivindicações indígenas, culturais, nacionais e éticas, recolocaria a concepção de nação (ibid.: 37). Ademais, em uma clara referência às análises de Rivera que retoma Ernest Bloch, Prada observa a "contemporaneidade do não-contemporâneo" nos eventos de setembro e outubro de 2003, a partir da "simultaneidade de acontecimentos passados, vividos também com grande intensidade, que se fazem presentes como pedindo para se completarem" (ibid.: 46, tradução minha). Segundo Prada, os eventos de setembro e outubro de 2003 seriam "resultado de um processo de acumulação dos movimentos sociais desencadeados em abril de 2000" (ibid.: 35, tradução minha). O autor entende que em outubro de 2003 "se cruzam dialeticamente a vertente indígena e a vertente nacional-popular, a memória longa e a memória curta, potencializando-se mutuamente" (2006: 57, tradução minha).

Gracía Linera et al. falam da consagração, em 2003, de "um novo bloco nacional-popular urbano-rural com uma hegemonia, organizativa e mobilizadora claramente indígena" (2008: 129, tradução minha). Luis Tapia (2007b) explica que nas rebeliões contemporâneas ocorridas no país haveria uma articulação entre o nacionalpopular e o comunitário indígena. Haveria assim dois "ciclos de rebelião" desencadeados recentemente. O primeiro seria o "ciclo de mobilização e rebeldia aymara-quéchua ou comunitária com suas extensões nas cidades andinas, em particular El Alto" e o segundo ciclo estaria relacionado ao campo do nacional-popular (ibid.: 185). A abertura do primeiro ciclo dataria na década de setenta e do segundo, da guerra da água (ibid.).

Hylton e Thomson apontam os eventos de outubro de 2003 como uns dos poucos momentos da história boliviana nos quais as lutas indígenas e as lutas nacionalpopulares convergiram, criando movimentos radicais e efeitos duradouros, indicando a 
possibilidade de cristalização de um novo bloco "nacional-popular" (2005: 43). Apesar do êxodo de camponeses do Altiplano em direção às cidades e às terras baixas, como resultado das políticas neoliberais, as solidariedades étnicas teriam sido reconstituídas nas "inchadas favelas" de El Alto e Cochabamba e entre os trabalhadores rurais nas terras baixas (ibid.). Assim como Prada, Hylton e Thomson destacam a autonomia das forças populares que, em outubro, deliberavam em assembleias abertas, sem uma liderança unificadora. Como consequência, não teria havido uma tentativa de toma da administração estatal da parte dos que participavam da insurreição (ibid.: 57).

Naquele "outubro negro", como é conhecido, o governo central respondeu às mobilizações populares com um massacre de civis. Primeiro, no dia dez de outubro, havia atacado os mineiros de Huanuni que marchavam em direção à La Paz, convocados pela Central Obrera Boliviana. Dois foram assassinados. No dia seguinte, em El Alto, tanques e helicópteros foram enviados para desmontar os bloqueios. Mais duas pessoas assassinadas, além de inúmeros feridos. A revolta popular cresceu em El Alto, assim como a repressão estatal. Nos dias seguintes, enfretamentos entre os moradores da cidade (alguns com pedras, outros com dinamite) e o exército levaram à morte de mais de 60 pessoas e centenas de feridos.

No dia 17 de outubro de 2003, Gonzalo Sánchez de Lozada fugiu do país em direção aos Estados Unidos. Com o "Goni”, ou o "gringo", como também era conhecido por falar o espanhol com um forte sotaque estadunidense ${ }^{106}$, fugiram seus ministros mais próximos, dentre eles, Sanchéz Berzaín, ministro de interior e um dos principais responsáveis pelo massacre cometido contra a população mobilizada.

A "guerra do gás" é sem dúvida um evento marcante na história política boliviana. Em seu nono aniversário, no dia 17 de outubro de 2012, pude acompanhar

\footnotetext{
${ }^{106}$ Sanchéz de Lozada viveu as primeiras décadas de sua vida nos Estados Unidos.
} 
uma marcha, que havia partido de El Alto em direção à embaixada dos Estados Unidos, pedindo a extradição de Sanchéz de Lozada e demais autores intelectuais da violência do Estado boliviano contra a sua população em 2003. Quase dez anos depois da fuga do ex-presidente, impressionou-me a enorme quantidade de pessoas que a formavam, milhares de mulheres de pollera que carregavam seus filhos nas $\operatorname{costas}^{107}$, milhares de jovens e homens que marchavam quilômetros e ocupavam as principais avenidas de La Paz, gritando "Goni assassino" e pedindo justiça ${ }^{108}$.

\subsection{Os últimos suspiros da antiga ordem}

Nos últimos dias de Sanchéz de Lozada no poder, o seu vice-presidente, Carlos Mesa, afastou-se do governo condenando a violência com a qual os insurretos haviam sido reprimidos. Sem filiação partidária e membro de uma elite econômica e intelectual de La Paz, Mesa é historiador e trabalhou como jornalista em diferentes meios de comunicação. Sua primeira candidatura a um cargo eletivo havia sido em 2002, na chapa de Gonzalo Sanchéz de Lozada.

A posse de Mesa representou uma ruptura no bloco de poder. Desde 1985, as elites de Santa Cruz, cujos representantes ocupavam direções partidárias, haviam participado dos diferentes governos, por exemplo, controlando importantes ministérios (García Linera, 2008b: 368). Os representantes dessas elites haviam apoiado o Goni até os últimos momentos de seu governo. Houve diferentes embates entre Mesa e essas elites durante o seu governo, tornando necessário o apoio do Movimiento al Socialismo

\footnotetext{
${ }^{107}$ Na Bolívia, a expressão "mujeres de pollera" (mulheres de saia) refere-se às mulheres indígenas das Terras Altas. A pollera é a saia usada tradicionalmente pelas mulheres indígenas do Altiplano boliviano, que podemos encontrar tanto no campo quanto nas grandes cidades como La Paz e Cochabamba. Foi interessante perceber que mesmo quando executavam trabalhos pesados nas ruas de La Paz, como a pavimentação de ruas e calçadas, as mulheres- pois não é raro ver mulheres empregadas nesse tipo de trabalho- usavam suas polleras.

${ }^{108} \mathrm{O}$ governo dos Estados Unidos negou reiterados pedidos de extradição desses políticos feitos pelo governo boliviano.
} 
(MAS), segunda maior bancada no Parlamento. Assim, pela primeira vez, o partido que havia sido formado pelo movimento camponês-indígena e havia se fortalecido com os votos daqueles que se levantavam contra a ordem vigente, era parte da base de apoio de um governo nacional, ainda que de forma extraoficial. E, consequentemente, um alicerce do sistema político.

Com a forte pressão popular para que se colocassem em prática as demandas que haviam vindo à tona durante a insurreição de 2003, a chamada "agenda de outubro"; em 2004, o governo de Mesa convocou um referendo sobre a concessão, a exportação e a utilização dos recursos do gás. Entretanto, muitos atores que haviam participado das mobilizações em defesa do gás, como a Fejuve- El Alto ${ }^{109}$, a CSUTCB, a COB e a Coordenadora pela defesa do gás, posicionaram-se contra o referendo dada a forma como as questões haviam sido elaboradas. Por outro lado, foi aprovada a "Lei de Agrupações Cidadãs e Povos Indígenas”, que acabava com o monopólio dos partidos políticos nas eleições. A ideia era criar outros meios de participação na Assembleia Constituinte que seria convocada. Segundo Webber, a tática adotada por Mesa em relação à Assembleia Constituinte era um "apoio retórico acompanhado de limitações nos possíveis alcances da Assembleia e atrasos por tempo indeterminado na sua realização" (2010: 56, tradução minha).

Ao mesmo tempo, em setembro de 2004, foi criado o "Pacto de Unidade" entre organizações indígenas e camponesas, com objetivo criar uma plataforma comum de propostas para a convocação da Assembleia Constituinte e para a nova Constituição. Os reflexos da marcha de 2002 aparecem na reunião de formação do Pacto, cuja grande ausente foi a Cidob.

${ }^{109}$ Federación de Juntas Vecinales de El Alto. 
A Assembleia Constituinte não chegou a ser convocada enquanto Mesa esteve no Palácio Presidencial, contudo, a nova Lei de Agrupações Cidadãs e Povos Indígenas esteve em vigor durante as eleições municipais de 2004. Nessas, apesar de ter sido o partido mais votado, o MAS recebeu nesta eleição apenas $18,4 \%$ dos votos a nível nacional $^{110}$. O segundo partido com maior votação foi o Movimiento Sin Miedo (MSM), com $8,7 \%$ dos votos. As eleições foram marcadas pelo enfraquecimento dos chamados partidos tradicionais; e, os verdadeiros vencedores foram as novas agrupações cidadãs, representantes de diferentes polos da política nacional (Hylton, Thomson, 2005; Webber, 2010). Para Romero Bonifaz, a lei que acaba com o monopólio dos partidos políticos estabelecia requisitos demasiadamente rígidos, com o intuito de modelar as agrupações cidadãs e as instâncias indígenas de participação à imagem da estrutura partidária (2005: 92). Nas Terras Altas, os povos indígenas apresentaram candidatos em apenas 68 dos 252 municípios e em 21 foram vencedores (Colque, 2009).

A aliança informal entre o partido de Evo Morales e o governo de Carlos Mesa já havia sido rompida após a realização do referendo sobre o gás. Naquela consulta, a população não fora questionada sobre a nacionalização dos hidrocarbonetos, mas sim sobre um possível aumento de impostos às empresas petroleiras. Dada a forma confusa por meio da qual foram elaboradas as perguntas do referendo, o partido aconselhara os bolivianos a votarem "sim" em algumas das perguntas e "não" em outras. O apoio do MAS à realização do referendo levou ao rompimento com algumas organizações sociais, dentre elas, a COB.

É pertinente a interpretação de Gutiérrez sobre essas duas ações do governo de Mesa como um “esforço sistemático de „pautar o tempo de maneira que certa capacidade básica de contenção política voltasse às mãos do estado" (2008: 246,

110 Fonte: http://www.bolivia.com/noticias/AutoNoticias/DetalleNoticia24248.asp, consultado em $20 / 02 / 2014$ 
tradução minha). Tal interpretação se justifica porque tanto no caso do referendo sobre o gás, como no caso da nova lei que deveria pautar a participação na Assembleia Constituinte, as mudanças propostas apontavam para uma transformação limitada no status quo, se comparada ao que havia sido reivindicado nas mobilizações sociais. No primeiro caso, "o núcleo deste reformismo neoliberal tinha como programa aceitar afrontar a demanda generalizada de um referendo sobre o gás sem que isto significasse substituir o modelo de privatização transnacional do setor", explica Luis Tapia (2005: 154, tradução minha). No caso da nova lei, ela excluía qualquer outra forma de participação na Assembleia Constituinte que não fosse através da “delegação da soberania" (Gutiérrez, 2008: 245).

No final de 2004, o frágil equilíbrio no qual se apoiava o governo de Carlos Mesa foi afetado pelo anúncio do aumento do preço da gasolina e do diesel que havia sido exigido pelo Fundo Monetário Internacional (Webber, 2010: 57) ${ }^{111}$. Setores subalternos de todo o país, assim como as elites econômicas e políticas da "Meia Lua", se posicionaram fortemente contra a medida governamental.

Em 2005, a crise política que estava em "estado latente" voltou a se agudizar. Em janeiro, a Federación de Juntas Vecinales de El Alto se mobilizou para expulsar a empresa Águas de Illimani, que, assim como àquela de Cochabamba, pertencia a uma transnacional. No começo de 2005, o movimento cocaleiro do Chapare, sob a liderança de Evo Morales, anunciara uma retomada dos bloqueios de estradas. O Consejo

\footnotetext{
${ }^{111} \mathrm{Na}$ Bolívia, a gasolina e o diesel são fortemente subsidiados. Mesa não foi o primeiro nem seria o último presidente a enfrentar a oposição da população à redução destes subsídios. Em 1979, o anúncio de sua suspensão, pelo governo de Lídia Gueiler, provocou uma forte reação do campesinato, "praticamente paralisando por uma semana todo o transporte motorizado no Altiplano e nos Vales" (Dunkerley, 2003 [1987]: 333).

Mais tarde, em 2010, o vice-presidente de Evo Morales, Álvaro Garcia Linera, assinaria um decreto que suspendia o subsídio à gasolina e ao diesel, elevando o preço do primeiro em $73 \%$ e, do segundo, em $82 \%$. A medida desencadeou uma onda de protestos de enorme magnitude, colocando em risco a estabilidade do governo, obrigando-o, então, a revogar o decreto (Fonte: http://www.bolpress.com/art.php?Cod=2010122608, consultado em 20/12/2011).
} 
Nacional de Markas y Ayllus del Qullasuyo (Conamaq) realizou outra marcha até La Paz, pela instauração da Assembleia Constituinte.

Em fevereiro, dirigentes do Comitê Cívico Pró-Santa Cruz, ao lado de organizações empresariais, entregaram à Corte Nacional Eleitoral assinaturas para a convocação de um referendo sobre autonomias departamentais ${ }^{112}$. Sem o apoio do MAS e da elite da Meia Lua, a fragilidade do governo Mesa se tornou evidente.

Para angariar apoio popular para a sua manutenção no cargo, em março de 2005, Mesa havia apresentado ao Congresso boliviano uma carta de renúncia, após um longo discurso televisivo no qual atacava diretamente Evo Morales e o principal dirigente da Fejuve-El Alto, além de criticar as elites políticas da Meia Lua. Sua estratégia foi parcialmente bem sucedida, pois angariou a adesão da classe média, estendendo a "sobrevida" de seu governo por mais alguns meses.

“A mobilização social entre março e junho de 2005 se detona, justamente, como uma grande disputa sobre as formas de modificar a relação entre as transnacionais petroleiras e o estado boliviano" (Gutiérrez, 2008: 284-5, tradução minha). Em março, de um lado, parte da classe média e empresários defendiam a Lei de Hidrocarbonetos proposta por Carlos Mesa e pediam que os recursos fossem administrados pelos departamentos; de outro, foram realizados bloqueios em El Alto e no Chapare. Este último grupo estava, todavia, dividido entre aqueles que exigiam a nacionalização dos hidrocarbonetos e os que queriam uma lei que aumentasse a um mínimo de $50 \%$ os impostos pagos pelas transnacionais, posição defendida pelo MAS (ibid.: 286-8).

Entre maio e junho, o MAS realizou uma marcha em defesa do pagamento de $50 \%$ dos recursos do gás pelas transnacionais ao Estado boliviano. Em El Alto, a mobilização demandava a nacionalização do gás e a instauração de uma Assembleia

${ }^{112}$ Fonte: http://www.rebelion.org/noticia.php?id=33580, consultado em 23/04/2014. 
Constituinte e rechaçava o referendo sobre autonomias departamentais. Foram realizadas marchas de mineiros e de camponeses, encabeçados por Román Loyaza (principal dirigente da parte da CSUTCB que não era liderada por Quipe). La Paz esteve cercada por três semanas (Patzi, 2007: 316-7).

Gutiérrez percebe, neste período, a existência de um crescente antagonismo entre quatro forças principais: o governo central, as elites orientais, o MAS e a população de El Alto e as comunidades aymaras. (2008: 288).

Jeffery R. Webber aponta a exacerbação da polarização política, a partir dos eixos de classe, raça e região durante o governo Mesa e vê a existência de dois blocos: o "bloco indígena-de esquerda" (left-indigenous bloc), cujas raízes se encontram nos departamentos de La Paz, Cochabamba, Oruro, Potosí e Chuquisaca, e o "bloco burguês-oriental" (eastern-bourgeois bloc), liderado pela burguesia dos departamentos ricos em hidrocarbonetos, Santa Cruz e Tarija, e seus aliados no Beni e em Pando, formando a chamada Meia Lua"113. A "agenda de outubro" seria defendida pelo primeiro bloco, ao passo que o segundo teria elaborado a "agenda de janeiro" de 2005. Esta incluiria a autonomia departamental, controle regional dos recursos naturais e sobre grande parte da renda dos impostos, capitalismo de "livre-comércio", racismo etc. Webber sublinha o apoio institucional e ideológico das empresas transnacionais petroleiras, do Fundo Monetário Internacional e da Embaixada dos Estados Unidos ao bloco burguês-oriental. Entre esses dois blocos estariam parte da classe média urbana e o MAS, sob a liderança de Evo Morales. As diferentes ações desses grupos teriam ajudado o fortalecimento de um e outro bloco dentro do governo de Carlos Mesa (2010:52-4). Por exemplo, entre outubro de 2003 e março de 2005, o movimento cocaleiro do Chapare não teria organizado nenhum bloqueio de estradas (ibid.: 56). Para

\footnotetext{
${ }^{113}$ O período de 2000-2005 seria marcado pelo fim da hegemonia neoliberal e pela rearticulação do bloco indígena-de esquerda (Webber, 2005).
} 
o autor, a estratégia do MAS era moderar a sua plataforma para conquistar a classe média urbana (ibid.: 57). Após o anúncio da "renúncia" de Mesa em março de 2005 e seu afastamento em relação ao MAS, Webber observa uma tentativa mal sucedida de aproximação do presidente boliviano com o bloco burguês-oriental.

Em consonância com a interpretação de Webber, Hylton e Thomson (2005) e García Linera (2008b) sublinham igualmente uma intensificação da polarização política a partir de diferenças étnico-raciais ou étnico-culturais, de classe e regionais. Félix Patzi fala da primazia de "dois projetos societais no cenário nacional" em 2005: a autonomia da oligarquia que defende o interesse do capital e a assembleia constituinte (2007: 313). Segundo o autor, os primeiros germens da "nação camba" teriam aparecido em 2000, em um momento em que o Movimiento sin Tierra fazia ocupações massivas de terras (ibid.: 308$)^{114}$. Em torno da defesa da "nação camba" contra o centralismo do Estado boliviano, a elite de Santa Cruz logrou angariar o apoio de parte importante da população do departamento, transformando uma reivindicação que naquele momento era de interesse da elite local, em uma demanda com apoio popular.

Em 28 de maio de 2005, foi realizada uma enorme assembleia (cabildo) na Praça San Francisco, centro de La Paz, no qual participaram moradores de El Alto e de comunidades do Altiplano de La Paz bem como um grupo de cocaleiros liderados por Evo Morales, que haviam organizado uma marcha até a cidade. No segundo dia do mês de junho, 60\% das estradas do país estavam bloqueadas (Gutiérrez, 2008: 291). Diferente de seu antecessor, o governo de Mesa não respondeu à mobilização social com repressão.

\footnotetext{
114 "O termo camba era até pouco tempo o nome depreciativo que os patrões brancos do Oriente davam aos seus peões e outros servidores indígenas locais. Apenas com a abertura do primeiro MNR ao Oriente foi adotado pelos criollos para se contraporem aos imigrantes collas andinos" (Albó, 2009: 179, tradução minha).
} 
No dia 6 de junho de 2005, Carlos Mesa renunciou. Os partidos tradicionais, as elites da "Meia Lua" e os movimentos indígenas e populares estavam contra o governo.

O processo de sucessão de Mesa envolveu uma grande disputa. Manteve-se a mobilização social e a cidade de Sucre, para onde havia sido transferido o Parlamento, foi ocupada por mineiros e camponeses. Os insurgentes se opunham à possibilidade do presidente do Senado, Hormando Vaca Díez, do MIR, ou do presidente da Câmara, Mario Cossío, os dois primeiros na linha de sucessão de Carlos Mesa, assumirem o Poder Executivo. A posse de Vaca Díez ou de Cossío representava a continuidade da ordem política que vinha sendo questionada nos anos anteriores. Essa era uma possibilidade inaceitável para aqueles que, mobilizados, haviam derrubado os dois últimos presidentes bolivianos. Ao impedir a posse daqueles representantes do Parlamento, a mobilização social provoca uma ruptura da ordem institucional, ampliando de forma definitiva o campo da política institucional para a participação daqueles que, até então, tinham as ruas e estradas bolivianas como cenário privilegiado, e praticamente único, para sua atuação política.

Entre os dias sete e oito de junho, o número de bloqueio de estradas subiu de 61 para 119; comunidades guaranis ocuparam sete campos de gás; três plantas hidroelétricas foram ocupadas; camponeses fecharam gasodutos; e cerca de cem greves de fomes foram decretadas em todos os departamentos, a maioria formada por representantes da classe média (Hylton, Thomson, 2005: 60). Finalmente, assumiu a Presidência da República Boliviana o terceiro na linha de sucessão, Eduardo Rodríguez Veltzé, então presidente da Suprema Corte de Justiça. Rodríguez Veltzé assumiu temporariamente a presidência do país até a convocação de novas eleições.

A importância da forte oposição das elites políticas e econômicas do Oriente boliviano ao governo de Carlos Mesa é apontada por Gutiérrez (2008), Webber (2010) e 
Tapia (2005). Este último afirma que apesar de, para o olhar estrangeiro, os movimentos sociais aparecerem como aqueles que expulsaram Mesa, as forças que boicotaram e conspiraram durante meses contra seu governo teriam sido os partidos políticos deslocados do poder central e, particularmente, a burguesia de Santa Cruz (Tapia, ibid.: 155-6). A bandeira política unificadora dos distintos segmentos sociais dos departamentos do Oriente do país, a chamada "Meia Lua", foi a autonomia departamental, que, como apresento no capítulo seguinte, teria grande influência no debate sobre autonomias indígenas na Assembleia Constituinte instaurada em $2006^{115}$.

A despeito da existência de um antigo regionalismo, sobretudo no departamento de Santa Cruz, autores concordam que o fortalecimento da demanda de autonomia departamental era em parte uma estratégia defensiva após o sucesso da mobilização indígena e popular dos anos anteriores (Tapia, 2005; Chávez, Mokrani, 2007; Gutiérrez, 2008; García Linera, 2008b). Os principais promotores da autonomia departamental eram os Comitês Cívicos dos departamentos da Meia Lua, principalmente o Comitê Cívico Pró-Santa Cruz. O fortalecimento da demanda de autonomia departamental indicava que as elites políticas e econômicas da Meia Lua percebiam uma tendência progressiva de seu afastamento do poder central, com a crescente polarização política desencadeada pelas mobilizações sociais dos anos anteriores.

No dia 28 de janeiro de 2005, enquanto em Santa Cruz se organizava um cabildo com cerca de 300 mil pessoas em defesa da autonomia departamental ${ }^{116}$, a Asamblea del Pueblo Guaraní (APG) estava reunida em Kuruyuki, cenário do último enfrentamento

\footnotetext{
115 García Linera explica que "diferente do que ocorre no Ocidente, onde os movimentos sociais populares e indígenas construíram um senso comum generalizado que explica as carências sociais, a falta de emprego, a discriminação e a crise devido ao ,modelo neoliberal'; no Oriente, os mesmos problemas que atravessam os setores subalternos são explicados pelo ,centralismo “e que é uma visão de mundo administrada pelas elites empresariais, o que permite entender sua liderança e base social" (2008b: 368, tradução minha).

${ }^{116}$ Sobre o cabildo organizado pelo Comitê Cívico Pró-Santa Cruz, tratou-se em realidade de uma grande festa com concertos de diferentes grupos. http://narcosphere.narconews.com/notebook/irene-rocaortiz/2005/01/santa-cruz-la-mascara-de-carnaval-de-la-autonom\%C3\%ADa , consultado em 02/03/2014.
} 
militar entre os guaranis e o Estado boliviano. Nesse dia, aniversário de 113 anos daquele massacre, a APG denunciava, dentre outros problemas, a falta de solução para o problema da escravidão enfrentado pelo povo guarani, os resultados insatisfatórios do processo de saneamento de terras; e, exigia a criação de um nono departamento, do Chaco, além da nacionalização do gás, "convocando aos milhares de despossuídos a se unirem contra o poder transnacional que hoje pretende nos dividir novamente para entregar nossa riqueza ao estrangeiro". O discurso dos guaranis nesse evento tornava evidente a possibilidade de articular os diferentes setores sociais no momento de uma grave crise política. Às suas reivindicações setoriais foram incorporadas demandas que envolviam todos os setores subalternos. O comunicado oficial enuncia:

Nós Guaranis não aceitamos nem aceitaremos que a oligarquia de Santa Cruz e de Tarija, e outras que hoje se expressam nos comitês cívicos, e outras instâncias, sob o "lema da autonomia", sigam usurpando nosso território e nossa riqueza e muito menos que falem em nosso nome. Nós Guaranis manifestamos a necessidade de refundar a nação boliviana a partir dos povos indígenas-originários, das comunidades, das juntas vecinales, dos comitês de bairros, dos sindicatos operários e das classes médias empobrecidas. Por isso convocamos a todos os setores do país a nos somar à convocatória e realização da Assembleia Constituinte por considerar que é o único caminho para encontrar um novo rumo à Nação Boliviana (tradução minha) ${ }^{117}$.

Em um artigo publicado originalmente em 2005, García Linera apontava que, naquele momento, nenhuma das "polaridades" ou "blocos" tinha a capacidade de imporse ao outro ou de seduzi-lo, configurando, assim, em termos gramscinianos, um “empate catastrófico". García Linera, que seria eleito vice-presidente da Bolívia em dezembro daquele ano ${ }^{118}$, apresenta então uma solução para este empate:

\footnotetext{
117 Pronunciamento disponível em http://archivos.bolivia.indymedia.org/es/2005/01/14456.shtml, consultado 02/03/2014.

${ }^{118}$ García Linera, que não era membro do MAS, foi escolhido para compor a chapa com Evo Morales provavelmente em uma tentativa de conquistar o voto das classes médias urbanas.
} 
Daí que o mais sensato seja pensar que a única maneira de solução deste "empate" seja precisamente o armistício ou, o que é o mesmo, uma redistribuição pactuada do poder estatal, o que levaria necessariamente a uma ampliação de direitos dos setores mais excluídos e a uma redistribuição negociada das oportunidades econômicas da sociedade (2008b: 373, traduçãominha).

\section{6. "Sempre fomos autônomos": a autonomia que aparece na crise}

Segundo Zavaleta Mercado, o estudo das crises políticas é o método privilegiado para entender a sociedade boliviana, em função do caráter "abigarrado" (heterogêneo, bagunçado) dessa. $\mathrm{O}$ autor afirma que na sociedade boliviana "a crise não atua como uma forma de violência sobre a ordem da rotina, mas como uma aparição patética das pontas da sociedade que, de outra maneira, manter-se-iam submergidas e gelatinosas" (2008: 19, tradução minha). Adolfo Gilly apresenta a existência de tempos distintos não apenas entre as classes subalternas, apontadas por Zavaleta Mercado, para o caso dos mineiros e do campesinato durante a greve geral de 1979, mas também entre estas e as classes dominantes:

Nesta esfera da subalternidade andina, onde têm refúgio afetos e respeito os oprimidos e os excluídos, mantêm-se e perpetuam-se as formas cotidianas de preservação da dignidade entre quem sabe e se considera igual e não tolera humilhações. Ali se preparam os tempos das rebeliões, que ninguém sabe quando serão, mas que quando chegam, os encontrarão com o ânimo disposto. É esse âmbito onde os modos de respeito humano dos subalternos se reproduzem no trato cotidiano, nos rituais, na festa ou no luto, nas famílias, nas amizades e entre gerações (2011: 23, tradução minha).

Para Gilly, os momentos de crise trazem para o primeiro plano duas esferas que "na rotina cotidiana da dominação parecem se confundir sob rituais e representações compartidas da hegemonia dominante": a da história institucional, dos "dominadores, 
oligárquicas ou nacionalistas" e aquela das classes subalternas (ibid.: 27-8). Trata-se de tempos entrecruzados, mas, diferentes.

Argumento que a crise que acabo de analisar tornou evidente não apenas a autonomização de organizações sociais no que tange o modelo de relação com o Estado de 52, mas, a crise explicitou igualmente as formas de articulação social e política autônomas que organizam a vida cotidiana de uma parte importante da população boliviana.

Neste capítulo, apresentei como a criação de autogovernos de facto, com a expulsão de representantes estatais, foi um dos resultados da insurgência social no Altiplano de La Paz. Contudo, a existência de formas de autonomia de facto foi não apenas um resultado dos levantes indígenas no período de crise política, mas também um elemento, cuja existência anterior às mobilizações, orientou a mobilização social.

Quando falo de autonomia de facto faço referência às formas plurais por meio das quais diferentes setores da sociedade civil boliviana articularam sistemas de organização territorial e política que se sobrepõem à lógica estatal, respondendo a uma ausência do Estado boliviano ou à necessidade de enfrentar este Estado, como no caso dos cocaleiros. Desse modo, não estou falando de um tipo de autonomia, mas de diferentes estratégias de articulação no interior das comunidades e entre elas.

A reforma constitucional de 1994, ao criar as figuras jurídicas das Terras Comunitárias de Origem (TCOs) e as Organizações Territoriais de Base (OTBs), reconheceu as autoridades indígenas, no primeiro caso, e as comunidades indígenas, no segundo. Esse reconhecimento foi, todavia, bastante limitado quando comparado à prática existente em grande parte das comunidades. 
Durante meu trabalho de campo, a existência de uma autonomia das comunidades indígenas, ainda que não reconhecida pelo Estado, foi afirmada por diferentes atores entrevistados. "Porque sempre fomos autônomos" foi a resposta que escutei diversas vezes à minha pergunta "por que vocês querem autonomia indígena?". Se sempre foram autônomos, por que então estariam pedindo o reconhecimento do Estado agora? "a autonomia não é novidade. Sempre fomos autônomos. Mas é autonomia sem recurso. Queremos uma autonomia com recurso do Estado", explicoume José Ortiz, liderança indígena da Amazônia, da Central de Pueblos Indígenas de La $\operatorname{Paz}(\mathrm{CPLAP})^{119}$

Um representante do Conamaq apontou igualmente a existência de autonomias de facto em algumas regiões do Altiplano:

Se durante gerações sempre fomos nos governando! (...) As autoridades originárias são o governo, não são organizações sociais, não são movimento social, são governo. A partir de 1492 tentaram fazer desaparecer as autoridades, seu governo próprio. Mas na maioria do Ocidente se manteve esse governo próprio. Por exemplo, em Apolobamba, uma das markas ${ }^{120}$, eles diziam: „Com governo ou sem governo do Estado boliviano nós sobrevivemos, no? Temos nosso governo próprio. Então não nos interessa muito se entra um governo de esquerda, de direita, de qualquer coisa, o que nos interessa é o nosso próprio governo ${ }^{\text {ee }}$ O governo próprio deles ${ }^{121}$.

Como apresentei na introdução deste trabalho, no Altiplano as comunidades conseguiram manter uma determinada independência em relação ao governo central, durante a colônia, através de acordos que Tristan Platt (1987) descreveu como um pacto de reciprocidade. A partir do final da segunda metade do século XIX, houve uma redução dessa autonomia.

\footnotetext{
${ }^{119}$ Entrevista realizada em La Paz, setembro de 2012.

${ }^{120}$ Vários ayllus formam uma unidade maior, a marka para os aymaras, ou o Jatun Ayllu para os quéchuas.

${ }_{121}$ Entrevista realizada em La Paz, setembro de 2012.
} 
Ao estudar as primeiras décadas do século XX, Silvia Rivera aponta como efeito contraditório da extinção jurídica das comunidades, no final do século XIX, e da expansão das haciendas, uma revitalização dos sistemas de autoridade comunal (1983: 79). As autoridades indígenas tinham funções relacionadas à organização interna da comunidade e como mediadoras entre esta e o Estado. Depois da Revolução de 1952, o sindicato passou a ser o interlocutor reconhecido pelo governo na sua relação com as comunidades indígenas e camponesas. Em alguns lugares, o sindicato se impôs como elemento central nas funções internas e externas à comunidade; já em outros, como no Norte de Potosí, Rivera explica que, enquanto as autoridades indígenas continuaram organizando a vida social e ritual das comunidades, o sindicato passou a ser o mediador entre os ayllus e o Estado (ibid.: 133). A autora esclarece que o apoio eleitoral dos camponeses do Norte de Potosí ao MNR deve ser entendido a partir da percepção dos comunais do equilíbrio histórico entre os ayllus e o Estado, sendo seu pré-requisito a manutenção do regime tributário e sistema de posse de terras, que garantiam a autonomia territorial e social dos primeiros (ibid).

Pablo Regalsky $(2003,2006)$ aponta a existência de uma autoridade territorial de facto dos sindicatos depois da Revolução de 52, através do controle do acesso à terra e da aplicação da justiça consuetudinária. Durante o pacto militar-camponês, havia uma disputa pelo controle dos sindicatos entre as elites locais e os governos comunitários. Com o fim do pacto, desapareceu o vínculo mediador entre o campesinato e o Estado e gerou-se um vazio de poder que levaria a um processo de reconfiguração das jurisdições comunitárias andinas. Ao mesmo tempo, uma estrutura de autoridades territoriais paralelas ao Estado era formada a partir da estrutura piramidal que havia sido criada depois da Revolução de 52. Para o autor, esse seria o início do processo de autonomia das comunidades andinas. Regalsky apresenta o estudo de caso das comunidades de 
Raqaypampa, no departamento de Cochabamba ${ }^{122}$. O autor mostra como, com a ruptura do pacto militar-camponês, os sindicatos camponeses recuperam sua autonomia em relação às elites locais, que haviam controlado a organização sindical. Se dentro das comunidades a reconstituição do sistema jurisdicional não necessitava ser um processo autoconsciente, sua reconstituição a nível regional, ou seja, entre comunidades, foi um “processo político consciente e explícito" (2003: 114-5).

Diferentes autores concordam que, em muitos casos, a criação dos sindicatos não implicou em maiores mudanças na organização local (cf. Albó, Romero, 2009; Puente, Longa, 2007; Patzi, 2007; Schilling-Vacaflor, 2008). Com nomes distintos, as autoridades comunais mantiveram as mesmas funções.

Em muitos lugares do Altiplano, a comunidade controla o acesso à terra, evitando a criação de um mercado capitalista de terras. E, ainda nos lugares onde não há este controle, como no caso dos trópicos de Cochabamaba, a posse de terra implica em obrigações em relação à comunidade e à estrutura organizacional. A participação nas assembleias comunitárias e o trabalho coletivo fazem parte dessas obrigações. $\mathrm{O}$ controle coletivo do acesso à terra funciona então como importante elemento articulador da comunidade (cf. Urioste et al.,2007; Regalsky, 2006; Rivera, 1990). Em muitas partes do Altiplano, na organização sociopolítica das comunidades, tanto indígenas como camponesas, a ocupação de cargos políticos e administrativos é obrigatória e se dá por turnos entre famílias. Para os cargos relacionados às organizações regionais ou departamentais, os turnos são organizados por parcialidades e comunidades. Tradicionalmente, existe o thakhi, que em aymara significa caminho, e refere-se a todos

122 Em dezembro de 2013, autoridades de Raqaypampa entregaram ao Tribunal Constitucional Plurinacional o estatuto elaborado para sua conversão em uma autonomia indígena originário camponesa (AIOC). Raqaypampa foi assim o primeiro e, até este momento, o único território titulado como Terra Comunitária de Origem (TCO) a entregar seu estatuto para a revisão por aquele tribunal. 
os postos de responsabilidade que um indivíduo adulto deve tradicionalmente ocupar até chegar aos cargos de maior autoridade. Algumas comunidades decidem, todavia, não respeitar o sistema de turnos e o thakhi. A escolha de jovens para importantes cargos em organizações nacionais, provavelmente em função de sua maior escolaridade e menor obrigação em relação à propriedade familiar, foi observada durante o trabalho de campo $^{123}$.

O grau de autonomia das comunidades em relação à ordem estatal varia muito no território boliviano. O que observamos é a existência na Bolívia de formas de organização territoriais locais independentes dos poderes e das normas estatais, que se articulam igualmente a nível regional e nacional, coordenando a vida política, econômica e social de parte da população, através, por exemplo, da administração da justiça comunitária e da distribuição das terras.

A partir de 2009, a nova Constituição Política Boliviana reconhece o direito à consolidação de autonomias indígenas originário camponesas, não se trata mais de autonomias construídas na prática cotidiana das comunidades, mas de uma autonomia reconhecida e regulada pelo Estado.

O tema da autonomia política indígena foi central nos levantes organizados no Altiplano pela CSUTCB entre 2000 e 2001. Seja através da construção de autonomias de facto, seja como elemento mobilizador da população. Entretanto, como argumentam García Linera et al, o tema não foi abordado nas negociações com o governo, deixando claro "que trava-se de um tema político que depende do desenvolvimento da correlação de forças sociais" (2008 [2004]: 182, tradução minha). Escrevendo dez anos depois da primeira edição do livro citado, corroboro a percepção dos autores sobre a importância

${ }^{123}$ São características das formas de organização local a curta duração dos mandatos e a impossibilidade que uma pessoa ocupe mais de uma vez o mesmo cargo. Em níveis mais altos de direções nacionais, às vezes esta lógica não é respeitada como, por exemplo, quando Felipe Quispe foi Secretário Executivo da CSUTCB, mas estes casos parecem excepcionais. 
de uma mudança na correlação de forças sociais para que a autonomia indígena fosse aceita como demanda pertinente no debate político nacional. Dessa transformação, derivou a inclusão deste direito na nova Constituição Boliviana promulgada em 2009, como veremos no próximo capítulo.

No capítulo 3, investigarei se tal reorganização da correlação de forças sociais foi suficiente para que a demanda de implantação de autonomias indígenas continue sendo percebida como legítima pelos atores políticos durante a segunda fase da longa crise política vivida pela Bolívia.

Ao analisar o que Dobry (1992 [1986]) chama das jogadas dos atores no período de crise política de 2000 a 2005, a partir dos estudos realizados por Raquel Gutierrez (2008), Pablo Mamani (2005) e Jeffery Webber (2010) sobre diferentes momentos da crise, é possível perceber as diversas alianças e disputas entre as organizações sociais, e entre estas e outros atores. Esta análise nos permite entender a relação entre o Estado e os indígenas, uma vez que o campo da política institucional foi modificado pela mobilização social.

Para entender a participação indígena no campo político boliviano pós-2006, seguirei no capítulo seguinte as jogadas dos diferentes atores durante o considero a segunda fase do segundo processo crítico boliviano (2006-2008). As ações dos atores e organizações serão apresentadas através do debate em torno das autonomias indígenas. Primeiramente, durante a Assembleia Constituinte, os debates sobre a questão autonômica serão centrais. Em segundo lugar, as autonomias indígenas representam, em grande medida, o questionamento do Estado boliviano, sendo assim, é pertinente indagarmos sobre o lugar desse projeto nas estratégias das organizações indígenas no momento em que o primeiro "presidente indígena" é eleito na Bolívia. Os próximos capítulos serão dedicados a este debate. 
Veremos que o estudo da dinâmica interna da crise que apresentei neste capítulo, em contraste com uma análise das causas da crise presente na revisão bibliográfica apresentada na introdução, possibilita uma melhor apreensão das relações de poder que virão à tona após a eleição de Evo Morales e do lugar que irão ocupar no campo político as organizações e atores indígenas mobilizados na primeira fase da crise. 


\section{Capítulo 3: A redação da Constituição em meio à reorganização política}

Para recordar a nuestros antepasados por su intermedio señor presidente del Congreso Nacional, pido un minuto de silencio para Manco Inca, Tupac Katari, Tupac Amaru, Bartolina Sisa, Zarate Willca, Atihuaiqui Tumpa, Andrés Ibáñez, Che Guevara, Marcelo Quiroga Santa Cruz, Luis Espinal, a muchos de mis hermanos caídos, cocaleros de la zona del trópico de Cochabamba, por los hermanos caídos en la defensa de la dignidad del pueblo alteño, de los mineros, de miles, de millones de seres humanos que han caído en toda América, por ellos, presidente, pido un minuto de silencio.

Discurso de posse de Evo Morales

En relación con los poderes constituidos, el Poder Constituyente es la vanguardia del proceso democrático, depositario del mandato social para transformar y construir un Nuevo Estado Boliviano.

Art. $1^{\circ}$ do Regulamento da Assembleia Constituinte ${ }^{124}$

Depois de um ciclo de mobilização popular que levou à queda de dois presidentes bolivianos, as eleições convocadas para dezembro de 2005 marcariam uma reordenação radical do campo da política institucional na Bolívia. Dos três principais partidos do período da democracia pactuada - MNR, MIR e ADN - apenas o Movimiento Nacionalista Revolucionario apresentou candidato para as eleições presidenciais. Desde a reforma aprovada durante o governo de Carlos Mesa, as elites

\footnotetext{
${ }^{124}$ Apud. Garcés, 2010b: 27.
} 
políticas e econômicas bolivianas haviam se organizado a partir das chamadas “agrupações cidadãs". Foi o caso, por exemplo, do Poder Democrático y Social (Podemos), criado em 2005, cujo principal representante era Jorge Quiroga, que havia sido eleito vice-presidente de Banzer em 1997, pelo partido Acción Democrática Nacionalista.

Por um lado, os resultados das eleições presidenciais de 2005 indicam a perda de apoio popular aos partidos que haviam composto a aliança que levaria Sánchez de Lozada à Presidência da Bolívia: o MIR não apresentou candidato; o MNR, que lançou à presidência um candidato filho de imigrantes japoneses e sem experiência política, Michiaki Nagatani, alcançaria apenas $6,46 \%$ do total de votos; e, o NFR, de Manfred Reyes Villas, receberia $0,68 \%$ de apoio à candidatura de Gildo Angulo ${ }^{125}$. Ao mesmo tempo, os resultados eleitorais de 2005 mostram a possibilidade de rearticulação de parte da elite política através das novas siglas. Esse é o caso da Frente de Unidad Nacional (UN), partido criado a partir de uma dissidência dentro do MIR, que recebeu 7,79\% dos votos com a candidatura de Samuel Doria Medina e Carlos Dabdoub. Doria Medina, apesar de relativamente jovem, representava a "velha política boliviana". Era um empresário que havia sido ministro de planejamento na década de 1990. Já Carlos Dabdoub, ex-presidente do Comitê Pró-Santa Cruz, representava o projeto autonômico da elite departamental. No entanto, o principal representante das posições privilegiadas na antiga configuração campo da política institucional era Jorge Quiroga, do Podemos, que ficou em segundo lugar nas eleições, com 28,59\% dos votos.

Embora tenham resistido à primeira fase do ciclo da crise política, esses representantes das antigas elites políticas perderam a posição privilegiada que ocupavam no campo da política institucional e, dessa forma, no governo nacional. Pela

\footnotetext{
${ }^{125}$ Para uma apresentação dos candidatos à Presidência nas eleições de dezembro de 2005, ver: http://www.bbc.co.uk/spanish/specials/1419 Bol candidatos/index.shtml , consultado em 14/05/2014.
} 
primeira vez de 1985, um partido que estava fora do sistema de acordos da democracia pactuada ganhou as eleições presidenciais. Nenhum "pacto" no Parlamento foi necessário para que fossem empossados Evo Morales Ayma e Álvaro García Linera. Com 53,74\% dos votos, pela primeira vez desde a volta à democracia, um partido alcançava a maioria nas urnas ${ }^{126}$.

Não obstante a vitória do Movimiento al Socialismo (MAS) para o Executivo nacional, a oposição elegeu a maioria no Senado e seis dos nove governadores departamentais.

No primeiro ano de seu governo, Morales implantou importantes demandas da “agenda de outubro". Em $1^{\circ}$ de maio, anunciou o decreto de nacionalização dos hidrocarbonetos, que culminou em uma negociação dos contratos de exploração destes recursos com as empresas multinacionais que atuavam no país. Em março, eleições haviam sido convocadas para a conformação da primeira assembleia constituinte a ser eleita democraticamente na história da Bolívia. Iniciava-se o "processo de mudança" (proceso de cambio).

Apesar do MAS contar com a maior bancada na câmara dos deputados, a maioria opositora que controlava a câmara alta dificultava as iniciativas de mudança. Um importante exemplo dos obstáculos impostos pelo Senado pode ser observado nas negociações para a elaboração da Lei de Convocatória da Assembleia Constituinte. Para a aprovação desta, o governo viu-se obrigado a concordar com a realização de referendos sobre as autonomias departamentais, bandeira da Meia Lua ${ }^{127}$. A nova lei

\footnotetext{
${ }^{126}$ Felipe Quispe e Camila Choquetilla, do Movimiento Indígena Pachakuti (MIP), ficaram em quinto lugar nas eleições com $2,15 \%$ dos votos. Para os resultados eleitorais ver: http://pdba.georgetown.edu/Elecdata/Bolivia/pres05.html, consultado em 14/05/2014.

${ }^{127}$ No referendo, a autonomia departamental foi aprovada em Santa Cruz, Beni, Tarija e Pando e perdeu em La Paz, Cochabamba, Oruro, Potosí e Chuquisaca. O MAS fez campanha pelo voto contra a autonomia. Para os resultados do referendo e da eleição de constituintes, consultar: Órgano Electoral Plurinacional http://www.oep.org.bo/centro_doc/separatas/acr2006 separata resultados.pdf.
} 
teria importantes consequências na participação das organizações indígenas e camponesas, articuladas em torno do Pacto de Unidade, no processo de "refundação do Estado" através a elaboração da nova constituição.

A crise política iniciada nos anos anteriores persistiria, mas, agora, com outras características. Se a primeira fase da crise (2000-2005) decorria do descompasso entre o Estado e sociedade; a segunda fase, que vai de 2006 a 2008, foi marcada pela reação daqueles que perderam o controle do poder central do Estado boliviano.

O novo governo, eleito em grande parte por aqueles que haviam se levantado nas revoltas populares dos anos precedentes, deslocou do Poder Executivo boliviano uma elite que historicamente havia combinado poder econômico e poder político. A análise de Luis Tapia (2010) é bastante esclarecedora sobre a articulação histórica entre as estruturas de poder patrimonial e o Estado boliviano e suas consequências para o período político iniciado em 2006, que o autor caracteriza como uma conjuntura de relativa autonomia do Estado.

Para Tapia, a história boliviana, desde a colônia, havia sido caracterizada pela articulação entre a classe de latifundiários (clase terrateniente) com o poder estatal. A exceção teria sido a primeira fase do Estado de 1952, que vai da Revolução até o golpe de Barrientos, em 1964. O autor chama de "presidencialismo colonial", o sistema operante de 1985 a 2005 no qual o "estado boliviano se encontrava em uma situação instrumental no sentido estrito do termo", o que Tapia explica pelo fato dos membros da classe economicamente dominante terem se convertido "na cabeça do Executivo; foram presidente, ministros, senadores e deputados, assim como também autoridades regionais e locais, isto é, governadores (prefectos) e prefeitos (alcades) ao longo do país" (idid.: 113, tradução minha). Seria essa instrumentalização, em sua faceta de presidencialismo colonial, que teria sido questionada nos ciclos de mobilização até 2005 (ibid.). A partir 
de então, o deslocamento de membros da classe dominante do Poder Executivo nacional e de alguns governos municipais e departamentais quebrou "o continuиm ou corrente de poder ou exercício do poder econômico, social e politico que se estabelecia entre as estruturas do estado boliviano e as estruturas de poder patrimonialista" (ibid.: 115, tradução minha). Contudo, o fato desta mudança não ter ocorrido de forma uniforme no território boliviano, tendo sido mais eficaz onde a estrutura patrimonialista já havia sido bastante modificada e substituída a partir da Revolução de 1952, e menos presente nos departamentos da Meia Lua, criou um "Estado dividido". Haveria então dois blocos sociais em contradição e "desencadeando uma intensa luta de classes através da forma aparente da discussão sobre a descentralização do Estado, em particular, sobre o projeto de autonomias departamentais" (ibid.: 121, tradução minha).

O "Estado dividido" descrito por Tapia será o cenário no qual se desenrolarão os debates da Assembleia Constituição. Assim, começo este capítulo com uma apresentação do Pacto de Unidade, ator central durante o processo constituinte, para, em

seguida, abordar as relações entre as organizações sociais e o MAS e o processo de polarização política e de crise que caracterizou o funcionamento da Assembleia Constituinte entre agosto de 2006 e dezembro de 2007. Analisarei a influência das diferentes disputas e alianças políticas na inclusão de uma importante demanda dos movimentos indígenas no texto constitucional: a autonomia indígena.

\subsection{O tempo comum do Pacto de Unidade}

Em março de 2004, organizações indígenas das Terras Baixas se reuniram em Concepción, departamento de Santa Cruz, para discutir os procedimentos e conteúdos 
da Assembleia Constituinte ${ }^{128}$. Esse foi um dos encontros e momentos nos quais as organizações sociais bolivianas vinham amadurecendo o debate sobre o novo texto constitucional. Assim, em setembro de 2004, em um encontro entre organizações indígenas e camponesas de todo o país realizado, na cidade de Camiri, nasceria o Pacto de Unidade. Esse espaço de encontro e debate seria fundamental no período da Assembleia Constituinte, entre 2006 e 2007. Através do Pacto de Unidade, as organizações sociais elaboraram uma proposta para a nova Constituição boliviana que teve grande influência no texto final aprovado pelos deputados constituintes em dezembro de 2007. Valencia e Égido destacam que dessa aproximação entre as diferentes organizações indígenas e camponesas, as últimas articularam um discurso de autoidentificação como indígena originários (2010: 46).

Durante o ciclo de crise política desencadeado nos anos anteriores, a convocação de uma Assembleia Constituinte foi uma das propostas apresentadas pelos movimentos sociais bolivianos para implantar reformas institucionais que estimavam necessárias. Assim, antes mesmo da convocatória para a eleição dos membros da Assembleia em março de 2006, as organizações sociais já haviam elaborado diferentes propostas para o novo texto constitucional. Não apenas as organizações matrizes, Conamaq, CSUTCB e Cidob, mas também diferentes organizações regionais e departamentais organizaram um processo de consulta às bases para preparar as propostas ${ }^{129}$.

Em maio de 2006, as organizações do Pacto de Unidade começaram a elaborar um projeto conjunto para a nova Constituição Política boliviana. No dia 5 de agosto daquele ano, um mês após a eleição dos membros da Assembleia Constituinte e um dia antes de sua inauguração, a primeira proposta das organizações indígenas e camponesas

\footnotetext{
${ }^{128} \mathrm{http}: / /$ www.rebelion.org/hemeroteca/internacional/040416andrade.htm, consultado em 25/03/2014.

${ }_{129}$ Para as diferentes propostas elaboradas ver: http://constituyentesoberana.org/3/propuestas/indiceosio.html, consultado em 27/03/2014.
} 
foi apresentada. Entre o encontro de Camiri, em setembro de 2004, e a apresentação do modelo de constituição elaborado pelas organizações sociais, houve momentos de aproximação e afastamento entre as algumas organizações e o Pacto. Contudo, quando se inaugurou a Assembleia Constituinte, as principais organizações estavam articuladas através do Pacto. Desta forma, a "Proposta das Organizações Indígenas, Originárias, Camponesas e de Colonizadores para a Assembleia Constituinte" foi assinada pelas seguintes organizações: Confederación Sindical Única de Trabajadores Campesinos de Bolivia (CSUTCB), Confederación de Pueblos Indígenas de Bolivia (Cidob), Confederación Sindical Única de Colonizadores de Bolivia (CSCB), Federación Nacional de Mujeres Campesinas de Bolivia, "Bartolina Sisa” (FNMCB-BS), Consejo Nacional de Ayllus y Markas del Qullasuyu (Conamaq), Coordinadora de Pueblos Étnicos de Santa Cruz (CPESC), Asamblea del Pueblo Guaraní (APG) e Confederación de Pueblos Étnicos Moxeños de Beni (CPEMB).

Em sua densa etnografia do processo constituinte boliviano, Salvador Schavelzon (2010) indica que, em determinados momentos, os projetos políticos das organizações camponesas, como a CSUTCB, mais próximas do partido do governo, e aqueles das organizações indígenas, como a Cidob e o Conamaq, dificultaram a adoção de uma proposta comum sobre determinados temas, como a titularidade de terras nos territórios "indígena originário camponeses" e a propriedade dos recursos naturais não renováveis nesses territórios.

Dadas as dificuldades de articulação entre as diferentes organizações durante o primeiro ciclo da crise política, essa falta de consenso não deve surpreender. Uma antiga assessora do Pacto de Unidade apontou a dificuldade das organizações indígenas 
em encontrar seu "inimigo comum": o inimigo, no caso dos indígenas das Terras Baixas, eram os grandes latifundiários, mas estes não existiam em Terras Altas ${ }^{130}$.

Os obstáculos à aliança entre as organizações existem inclusive dentro de cada região. A CSUTCB e o Conamaq, por exemplo, apesar de serem fundamentalmente organizações do Altiplano, são bastante distintas. Como apresentei no capítulo 1, enquanto a primeira nasce, em 1979, em torno de uma estrutura sindical, o Conamaq, formado quase vinte anos mais tarde, busca a "reconstrução e consolidação dos povos indígenas originários, sob sua própria estrutura social, filosófica, política, econômica e cultural" (Conamaq, 2008: 3, tradução minha). Embora tanto o Conamaq quanto a CSUTCB incorporem "certos elementos do ayllu em seu modo de organização e de sua compreensão do político", o primeiro critica organizações sindicais (como a CSUTCB e os cocaleiros) por representarem formas de organização impostas do exterior. Por outro lado, os ayllus são acusados pelos sindicatos de serem radicais (Schilling-Vacaflor, 2008: 3-4, tradução minha). Os representantes do Conamaq consideram-se, assim, "mais indígenas" que os membros dos sindicatos (ibid.: 7) ${ }^{131}$.

A distância entre essas duas organizações sociais se mostrou evidente em 2000: enquanto a CSUTCB organizava importantes mobilizações no Altiplano boliviano contra o governo de Hugo Banzer, lideranças do Conamaq brindam apoio ao presidente boliviano entregando-lhe um poncho e um bastão, símbolos de autoridade. Felipe Quispe comenta que quando foi eleito Secretário Executivo da CSUTCB, em 1998, o Conamaq havia ocupado o lugar da confederação camponesa em grande parte do

\footnotetext{
${ }^{130}$ Entrevista realizada em La Paz, outubro de 2012.

${ }^{131}$ A observação de Schilling-Vacaflor sobre os representantes do Conamaq se considerarem "mais indígenas" que os do sindicado corrobora a minha observação durante o trabalho de campo. Esse foi iniciado quatro anos depois da publicação do texto da autora, em um contexto político distinto, com maior polarização entre as organizações indígenas e camponesas, mas, chamou-me a atenção a constante reafirmação por parte dos atores da distinção entre indígenas e camponeses e os inúmeros conflitos que opunham as organizações. Retomarei este ponto no capítulo seguinte, que abarca o período no qual pude observar de perto tais polarizações.
} 
Altiplano, principalmente no departamento de La Paz. Contudo, a partir desta aproximação das autoridades do Conamaq com Banzer, as bases se afastaram da organização e se reaproximaram da CSUTCB. “Aí caíram. Então quando eu ia visitar as comunidades que eram Conamaq, estavam esperando com uma forca, para enforcar a esses traidores”, explica Quispe ${ }^{132}$. Sobre a aproximação entre a autoridade máxima do Conamaq e Banzer, Albó explica que o primeiro foi destituído pelas bases da organização em Oruro (2009: 169). "Desde então começará uma virada, ainda que parcial, nesta organização" (ibid., tradução minha).

Para além de um problema com as lideranças do Conamaq, o episódio descrito parece refletir a estratégia da organização indicada por García Linera et al.: a "defesa dos direitos locais dos ayllus em troca do reconhecimento e legitimação histórica da estrutura estatal dominante" (ibid.: 337, tradução minha).

Sobre as dificuldades de articulação entre a CSUTCB e a Cidob, o caso da marcha organizada pelas organizações camponesas e pela CSUTCB contra a Lei Inra é um bom exemplo. Como apresentado no capítulo 1, a Cidob abandonou a marcha depois de negociar com o governo a inclusão das Terras Comunitárias de Origem no texto da nova lei.

Os obstáculos à formação de alianças podem ser igualmente observados entre as organizações indígenas das Terras Baixas. Um exemplo foram os conflitos internos que culminaram com a saída da Central de Pueblos Étnicos de Santa Cruz (CPESC) da estrutura da Cidob, em 2002. A CPESC era uma importante organização regional da Cidob e diferenças em relação às estratégias de ação teriam motivado a ruptura. Diferenças estas relacionadas à postura negociadora da Cidob em relação ao governo,

\footnotetext{
${ }^{132}$ Entrevista realizada em La Paz, dezembro de 2013.
} 
como durante a Marcha pela Assembleia Constituinte, em $2002^{133}$. Esse fato explicaria o porquê da CPESC, e não a Cidob, ter sido a principal organização das Terras Baixas presente nos primeiros momentos de articulação do Pacto de Unidade. Ao longo de 2005 e 2006, entretanto, houve um processo de reaproximação entre as duas organizações.

A despeito das diferenças latentes entre as organizações indígenas estudadas, houve diversos momentos em que essas trabalharam em sintonia. Xavier Albó descreve, por exemplo, um encontro bastante simbólico entre a CSUTCB e a Cidob que ocorreu durante a Marcha de 1990. No cume da Cordilheira Andina, os indígenas das Terras Baixas que marchavam foram recebidos por quéchuas e aymaras da CSUTCB e, em um ritual, sacrificaram lhamas e um pacto de sangue foi selado (2007: 93). O autor aponta que a dificuldade, por parte da CSUTCB e da COB, em compreender a organização das Terras Baixas não impediu que houvesse uma cooperação entre as organizações indígenas, nos anos que se seguiram à marcha, para a elaboração de uma proposta comum de "lei indígena" (ibid.). Como consequência deste encontro, Albó destaca "uma ampliação do horizonte temático" das organizações (ibid.).

Segundo Marcial Fabriciano, ex-presidente da Cidob, foi durante a marcha de 1990 que se deram os primeiros contatos entre a sua organização e um grupo de líderes indígenas que mais tarde formaria o Conamaq (entrevista publicada em Calderón, 2002: 89). O líder da organização das Terras Baixas explica que logo depois da fundação do Conamaq, em 1997, as duas organizações realizavam assembleias comuns e a Cidob ajudava a organização do Altiplano a conseguir financiamento. Essa relação pode ser

\footnotetext{
${ }^{133}$ Para Garcia Linera et al., as razões da postura conciliadora da Cidob são encontradas na grande dificuldade de mobilização da organização dos indígenas das Terras Baixas, em função da baixa densidade demográfica, da sua dispersão em um grande território e a ausência de mecanismos comunitários que imponham a participação em manifestações, à diferença das comunidades no Altiplano (2010: 229).
} 
entendida à luz das explicações de McAdam (1994) sobre os processos de enquadramento interpretativo elaborados pelos movimentos sociais. $\mathrm{O}$ autor aponta que novos grupos tendem a se inspirar em frames bem-sucedidos. Fabriciano, contudo, ressalta que foi contra a formação de uma única organização comum, pois, estaria ressurgindo no Altiplano "um ressentimento cultural histórico", e os indígenas das Terras Baixas não teriam absolutamente nenhuma relação com esse processo orgânico, iniciado nos anos de setenta (Calderón, 2002: 89-90). O líder indígena afirma então:

E falando do cultural, muito bem, nós dizemos, está bem que reivindiquem o que era o Tahantinsuyo $^{134}$ ou o Collasuyo, tudo que era a Bolívia, mas nossos comunarios dizem que nós não somos Suyo de ninguém, que aqui os conquistadores nunca chegaram (ibid.: 89 , tradução minha) $)^{135}$.

A aproximação, na década de noventa, não foi progressiva, tendo ocorrido por meio de avanços e retrocessos. Em 1992, o aniversário de quinhentos anos da invasão da América pela Espanha serviu como estímulo para a articulação de manifestações comuns com diferentes organizações indígenas do país. Contudo, a frustrada tentativa de construção da chamada "Assembleia das Nacionalidades", naquele mesmo ano, que almejava unir diferentes grupos indígenas do país, evidenciou a disputa entre esses grupos.

As diferenças assinaladas acima reforçam a excepcionalidade de um momento que conseguiu articular forças sociais tão distintas como organizações camponesas, organizações indígenas do Altiplano e organizações indígenas das Terras Baixas. Apesar de ter havido, antes da formação do Pacto de Unidade, breves momentos em que

\footnotetext{
${ }^{134}$ O Tawantisuyo era a denominação para o território que abarcava o Império Inca.

135 As afirmações de Marcial Fabriciano corroboram a observação de Molina (2008), segundo a qual, diferente dos indígenas do Altiplano, os indígenas das Terras Baixas ratificavam a sua adesão à comunidade nacional, ao mesmo tempo que reivindicavam maior participação política, cidadania e reconhecimento dos grupos étnicos como culturas diferentes.
} 
as diferentes organizações indígenas e camponesas se aproximaram, nenhuma aliança anterior pode ser comparada em termos de impacto político no cenário nacional àquela realizada durante o processo constituinte.

No momento inicial de formação do Pacto de Unidade, em 2004, e durante a elaboração da primeira proposta de constituição apresentada em agosto de 2006, participaram diferentes organizações locais e departamentais. Mas, progressivamente, as decisões foram sendo concentradas pelas cinco organizações matrizes nacionais: CSUTCB, FNMCB-BS, CSCB, Conamaq e Cidob.

A primeira proposta para a nova constituição apresentada pelo Pacto em 2006 foi elaborada a partir de diferentes encontros realizados naquele ano entre as organizações sociais e com o apoio técnico de organizações não governamentais ${ }^{136}$. Formou-se uma comissão técnica e eventos foram organizados para recolher sugestões para a proposta do Pacto e para apresentá-la às bases das organizações indígenas e camponesas $^{137}$. O esboço de constituição abarcava todos os temas e não somente aqueles que poderiam ser considerados de interesse específico dos indígenas e camponeses. Tratava-se de um projeto para uma nova ordem política e econômica, que involucrava a todos os bolivianos.

Os projetos de constituição elaborados pelas diferentes organizações indígenas e camponesas divergiam em alguns pontos. Uma antiga assessora do Pacto aponta a

\footnotetext{
${ }^{136}$ Um documento publicado pelo Cejis, ONG que trabalhou com o Pacto de Unidade explica: "Um princípio regeu o processo desde o início (maio de 2006), foi definir que o papel das instituições de apoio era somente o de facilitadoras. Por essa razão, não podiam se aproveitar de seus conhecimentos jurídicos e políticos, nem se apropriar dos resultados como prova de respeito às organizações a quem prestavam um serviço. Para tanto, acordou-se que em todos os espaços de trabalho a comissão técnica estaria acompanhada de pelo menos um dirigente de cada organização social. Esta decisão funcionou". Em maio de 2006, as organizações não governamentais que davam apoio ao Pacto de Unidade eram as seguintes: Cenda, Cepas-Caritas, Programa Nina-Unitas, Cejis, Água Sustentable, Cesa, SNV (como assessora da CPESC). Ao final do processo estavam também o Fundo Indígena, a Cefrec e o Cipca (Valencia, Égido, 2010: 70, tradução minha).

${ }^{137}$ Nos meses anteriores, a CPESC havia desenvolvido um longo trabalho de apresentação e recolhimento de propostas nas comunidades que seriam incluídas em seu projeto de constituição (Valencia, Égido, 2010: 41).
} 
justiça e a autonomia indígenas como temas divergentes entre as organizações sociais. Além disso, não havia consenso em torno da demanda da Asamblea del Pubelo Guaraní (APG) e do Conamaq para a criação de estados confederados, tendo sido esta proposta descartada durante os debates que antecederam a Assembleia Constituinte. Nesse sentido, a proposta apresentada pelo pacto em agosto de 2006 foi o resultado de um importante processo de construção de consenso entre as organizações nos meses que antecederam a inauguração da Assembleia Constituinte na cidade de Sucre ${ }^{138}$. Valencia e Égido indicam o consenso em torno do uso do termo "indígena originário camponês" como solução para a tensão existente entre os representantes da CSUTCB e do Conamaq (2010: 68). A utilização do termo sublinhava a identidade comum de atores que em comunidades andinas e nos Vales se organizavam, não sem tensões, em estruturas distintas. "Chegava ao fim momentaneamente o longo e acalorado debate sobre as diferenças entre nação, nacionalidade, povo, comunidade, camponês originário, camponês, colono, comunidade intercultural, etnia e grupo étnico" (ibid.: 68-9, tradução minha).

Apesar da existência de uma proposta acordada entre as organizações do Pacto, o Conamaq apresentou seu próprio projeto de constituição. Assim como o Conamaq, a Asamblea del Pueblo Guaraní (APG) participou da elaboração das propostas do Pacto de Unidade, mas manteve sua própria agenda (Valencia, Égido, 2010: 88). A APG, o Conamaq e a Cidob formaram o Bloco Indígena (ibid.). Essas organizações coincidiam em muitos pontos que lhes colocavam em dissenso com as organizações de matriz camponesa, que eram mais próximas ao MAS. A mesma assessora do Pacto citada acima explicou que, ainda que esses conflitos tenham aparecido durante a Assembleia Constituinte, predominava a "agenda macro" sobre os interesses particulares, "as

\footnotetext{
${ }^{138}$ Entrevista realizada em La Paz, outubro de 2012.
} 
vontades de construir ou reconstruir um país que estava a ponto de cair" ${ }^{139}$. Fernando Garcés interpreta da seguinte forma a aliança entre as diferentes organizações:

O Pacto de Unidade não era um espaço uniforme e homogêneo, mas também não era um espaço de trincheiras inflexíveis; movia-se de forma complexa em uma série de acordos que, segundo os momentos políticos, os temas em discussão, os interesses particulares, posicionava as organizações em alianças mais amplas (o próprio Pacto de Unidade) ou em uma série de subalianças internas (Garcés, 2010b: 82, tradução minha).

À dificuldade em construir uma proposta comum entre as organizações sociais do Pacto, acrescentou-se a necessidade de acordo com o governo e os constituintes do MAS. Garcés ressalta que o fato das organizações verem-se obrigadas a se relacionarem com atores externos durante o processo constituinte, como a bancada do MAS na Assembleia Constituinte e assessores do Poder Executivo, fragilizava, de certa forma, a aliança entre as organizações, que se expunha ao perigo de ruptura (ibid.: 82).

O Pacto de Unidade apresentaria sua proposta final para a constituição em maio de 2007. O tempo que havia transcorrido entre a inauguração da Assembleia, em agosto de 2006, e a divulgação da última proposta do Pacto foi marcado por uma intensa polarização política entre os constituintes próximos ao governo e os de oposição e por alianças e acordos que teriam reflexos importantes na incorporação ou no rechaço de demandas das organizações do Pacto.

\subsection{A aliança entre o MAS e as organizações indígenas e camponesas}

A eleição de representantes dos povos e nações indígenas por meio de formas próprias de escolha era uma demanda central para estes. A proposta da Cidob incluía a

${ }^{139}$ Entrevista realizada em La Paz, outubro de 2012. 
eleição por normas e procedimentos próprios e 34 representantes para cada povo das Terras Baixas e três para os povos com maior população (Valencia, Égido, 2010: 42). A CPESC e demais organizações do Bloco Oriente reivindicavam a eleição de dez constituintes em circunscrições eleitorais especiais para os indígenas das Terras Baixas e para os afrobolivianos, através do voto secreto de candidatos indicados segundo mecanismos próprios de cada organização (ibid.). A proposta do Conamaq reivindicava igualmente que a participação na Assembleia Constituinte se desse através das organizações tradicionais, com eleição direta, segundo usos e costumes (García Linera et al., 2008: 346).

Em setembro de 2004, uma proposta elaborada por diferentes organizações sociais, incluindo o Conamaq, a CSUTCB (dirigida por Román Loayza), a CPESC e a APG, dentre outras, recomendava a formação de 26 circunscrições especiais étnicas para as eleições de constituintes (ibid.: 346) ${ }^{140}$. Contudo, em 2006, quando o MAS elbaora a Lei de Convocatória, esta ignorava a representação direta e as circunscrições especiais propostas pelas organizações indígenas. Naquele momento, a proposta do governo contava com o apoio das principais organizações camponesas.

Para compensar a ausência de circinscrições especiais - nas quais os povos indígenas teriam representação direta na Assembleia Constituinte - o governo acordou com as organizações indígenas a indicação em primeiro lugar nas listas do MAS de representantes dos povos indígenas nas circunscrições onde existissem população e

\footnotetext{
${ }^{140}$ No livro, publicado pela primeira vez em 2004, organizado por García Linera, que viria ser o vicepresidente de Evo Morales, encontramos uma crítica a esta proposta acordada em 2004 entre as organizações: "O problema com essa forma de seleção dos constituintes das Terras Baixas (sic) é que desconhece outras estruturas organizativas dos povos indígenas, inclusive em alguns casos, mais representativas e com maior peso político que os próprios ayllus reconstituídos (o sindicalismo agrário do Altiplano Norte). Ademais, divide em identidades locais umas identidades indígenas maiores que, como a aymara, adquiriram força política atual não a partir das micro identidades regionais estatalmente reconhecidas e fomentadas, mas precisamente a partir da construção de uma identidade nacional indígena maior macrorregional" (García Linera et al., 2008: 346-347).
} 
território indígena. Esse acordo, no entanto, seria mais tarde parcialmente descumprido pelo governo (Valencia, Égido, 2010: 43-4).

Em julho de 2006, foram eleitos os 255 membros da Assembleia Constituinte, dos quais 210 por circunscrições eleitorais "uninominais" e 45 por "plurinominais". No primeiro caso, foram eleitos dois candidatos pela maioria e um pela minoria. No caso dos candidatos de circunscrições plurinominais, foram escolhidos cinco representantes por departamento: dois pela maioria; um para cada partido que ficasse em segundo e terceiro lugar; e, o último representante para o partido que ficasse em quarto lugar, caso recebesse mais de 5\% dos votos (Schavelzon, 2010: 120). Tal como haviam sido acordadas com a oposição, as regras para a eleição para os membros da Assembleia Constituinte impediam que um partido alcançasse dois terços das cadeiras, ainda que ganhasse em todas as circunscrições eleitorais a nível departamental (Albó, 2008). Essa limitação seria importante no desenvolvimento da Assembleia Constituinte, pois, a oposição foi intransigente em sua demanda de que o novo texto fosse aprovado por no mínimo dois terços dos constituintes.

O acordo com a oposição resultou na eleição de 137 representantes do MAS, alcançando $53,7 \%$ das cadeiras, o que significava $2,7 \%$ a mais que os votos recebidos pelo partido. Mas a distorção entre votos recebidos e número de constituintes eleitos seria muito mais favorável à primeira força de oposição, a agrupação cidadã, Poder Democratico y Social (Podemos), que recebeu 15\% dos votos, mas elegeu 60 constituintes, o equivalente a 23,5\% do total de cadeiras (Albó, Carrasco, 2009: 49). Além do MAS e do Podemos, outros 14 partidos ou agrupações cidadãs elegeram deputados constituintes. Com o maior número de representantes, o Movimiento Bolivia Libre (MBL), o Movimiento Nacionalista Revolucionario (MNR), o Movimiento 
Nacionalista Revolucionário - Frente Revolucionario de Izquierda (MNR - FRI) e a

Unidad Nancional (UN), elegeram oito constituintes cada um (ibid.: 50).

Segundo o estudo de Iamamoto (2011), dentre as agrupações que apoiavam o "processo de mudança" estavam a Alianza Social (AS), a Alianza Social Patriótica (ASP), o Movimiento Ayra (Ayra), a Concertación Nacional - Patria Insurgente (CNPI), o MAS-IPSP, o Movimiento Bolivia Libre (MBL), o Movimiento Ciudadano San Felipe de Austria (MCSFA) e o Movimiento Originario Popular (MOP). Iamamoto explica que essas siglas haviam sido usadas, em muitos casos, para ampliar a representação do MAS na constituinte, que alcançava com este bloco $64 \%$ das cadeiras (ibid.: 88$)^{141}$. Os outros $36 \%$, ou seja, 91 cadeiras, eram ocupados por agrupações que "se alinhavavam mais claramente com a oposição": Alianza Andrés Ibáñez. (AAI), Autonomías para Bolivia (APB), Movimiento Nacionalista Revolucionário (MNR), Movimiento Nacionalista Revolucionário - A3 (MNR-A3), Movimiento Nacionalista Revolucionario - Frente Revolucionario de Izquierda (MNR-FRI), Movimiento de Izquierda Revolucionaria - Nueva Mayoría (MIR-NM), Unidad Nacional (UN) e Podemos (ibid.).

Em uma enquete realizada por Albó (2008) com todos os membros da Assembleia, $69,8 \%$ dos entrevistados se declararam mestiços, enquanto $26,7 \%$ indígenas/originários e 3,6\% brancos. Ao mesmo tempo, 55,8\% dos entrevistados declararam pertencer a algum povo originário e 30,2\% havia aprendido alguma língua indígena na infância. Na Enciclopédia da Assembleia Constituinte é possível notar que

\footnotetext{
${ }^{141}$ Albó e Carrasco dão o exemplo do MBL, em Cochabamba. Lá o MAS tinha o apoio da grande maioria dos eleitores - o MBL emprestou então a sigla para o MAS para eleger um terceiro constituinte. Dentre os oito constituintes do MBL, cinco eram na verdade do MAS, explicam os autores (2009: nota 7).
} 
muitos de seus membros se autoidentificam ao mesmo tempo mestiços e aymara ou quéchua.

Quadro1: Membros da Assembleia Constituinte pertencentes a povos indígena originários segundo autoidentificação

\begin{tabular}{|c|c|c|}
\hline Povo indígena originário & $\mathrm{N}^{0}$ e $\%$ de constituintes seg & indo autoidentificação \\
\hline Quéchua & 81 constituintes & $-\quad 31,76 \%$ \\
\hline Aymara & 43 constituintes & $-\quad 16,86 \%$ \\
\hline Chiquitano & 6 constituintes & $2,35 \%$ \\
\hline Mojeño & 4 constituintes & $1,57 \%$ \\
\hline Tacana & 4 constituintes & $1,57 \%$ \\
\hline Guarani & 1 constituinte & $0,39 \%$ \\
\hline Guarayo & 1 constituinte & $0,39 \%$ \\
\hline Itonama & 1 constituinte & $0,39 \%$ \\
\hline Joaquiniano & 1 constituinte & $0,39 \%$ \\
\hline Não pertence & 113 constituintes & $44,31 \%$ \\
\hline Total & 255 constituintes & $100 \%$ \\
\hline
\end{tabular}

Fonte: Garcés, 2010b (com base em Albó, 2008).

Albó (2008) explica como alguns constituintes da oposição se identificavam como indígenas sem o serem. Se, tal como argumenta Linera (2007), a etnicidade na Bolívia é um capital simbólico que influi na eficiência dos demais (no caso de ser indígena, esta influência é negativa), as cifras apresentadas acima poderiam indicar uma mudança importante, com a valorização da identidade indígena dentro da política institucional boliviana após a primeira fase do processo de crise política que levou à eleição de Evo Morales e à Assembleia Constituinte. Esse novo cenário corrobora a tese de Dobry (1992 [1986]), que indica uma mudança das lógicas setoriais e capitais 
valorizados em cada campo social a partir da fluidez das fronteiras entre os setores, desencadeada por um processo de grave crise política. Se anteriormente à crise, ser indígena era uma desvantagem no campo da política institucionalizada, a Assembleia Constituinte poderia indicar uma valorização desse capital no campo.

O estudo de Albó (2008) apresenta muitas informações relevantes sobre os constituintes. Uma delas indica que 16,9\% dos membros da Assembleia residiam em comunidades rurais no momento da eleição, $15,7 \%$ em povoados centrais, $14,5 \%$ em cidades intermediárias e 52,9\% nas capitais dos departamentos ou em cidades grandes. Dos 255 constituintes, $28,2 \%$ haviam nascido em comunidades rurais e $20,8 \%$ em povoados centrais. O fato de haver um serviço de tradução simultânea em cinco idiomas durante a Assembleia Constituinte indica a importância da participação indígena e camponesa neste cenário.

Os dados da pesquisa realizada por Albó são importantes, todavia, tais estatísticas não nos permitem observar uma limitação não negligenciável da abertura do campo político institucionalizado para camponeses, indígenas, trabalhadores pobres, pequenos comerciantes, durante a Assembleia Constituinte: a manutenção das antigas regras do jogo. Ou seja, dever-se-ia refundar o Estado a partir das regras do antigo Estado. Sendo assim, lideranças sociais e projetos políticos foram excluídos. No caso dos indígenas das Terras Baixas, por exemplo, dado que as demandas de suas organizações não foram contempladas na Lei de Convocatória, e o MAS tampouco respeitou seu acordo, apenas quatro representantes desses povos foram eleitos nas listas do partido do governo. Como veremos adiante, além de influenciar a composição da Assembleia, a manutenção das lógicas políticas estatais existentes irá igualmente influenciar o rumo dos debates em torno do novo texto constitucional e sua elaboração final. A manutenção das lógicas de "fazer política" possivelmente explica o fato 
apontado por Silvia Rivera: representantes mestiços terem se tornado porta-vozes dos indígenas, negociando suas demandas com as elites e a direita durante a Assembleia Constituinte, como ocorria nos tempos de "multiculturalismo oficial", durante a década de 1990 (2007: 2).

A bancada do MAS na Assembleia era formada pelos "orgânicos", indicados pelas organizações sociais e que respondiam ao mandato destas, e, os "convidados", que eram intelectuais e profissionais urbanos que, na maioria dos casos, tinham grande afinidade com as demandas do Pacto de Unidade, ainda que não pertencessem a organizações indígenas ou sindicatos camponeses. A despeito desta afinidade, em função da composição heterogenea da bancada do MAS, era necessário que os representantes do Pacto difundissem a sua proposta entre os constituintes do partido e ganhassem o seu apoio (Garcés, 2010b: 84).

Deste modo, a forma como a Lei de Convocatória para a Assembleia Constituinte foi redigida tornou imperativo o trabalho de cooperação entre as organizações do Pacto de Unidade e o MAS, principalmente no caso das organizações indígenas que não pertenciam ao partido, notadamente, a Cidob, o Conamaq, a CPESC e a APG. Schavelzon conta o caso da constituinte Nélida Faldin, do povo chiquitano, que foi eleita dentro da lista do MAS disputando com candidatos de outras etnias que terminaram sem representação na Assembleia. Por seu povo representar uma minoria local, Nélida contou com o voto dos camponeses para ser eleita e "somente pôde permanecer por um aval de Evo Morales que, no lugar de beneficiar a seus aliados mais próximos, os camponeses colonizadores, definiu que esse lugar seria para povos indígenas" (ibid.: 139- 140).

Assim como as organizações do Pacto de Unidade dependiam fortemente do MAS e seus 137 constituintes, o partido de Evo Morales necessitava do apoio das suas 
organizações indígenas. Essa necessidade devia-se não somente ao fato das organizações estarem presentes e bem organizadas em Sucre, com assessores e o apoio de organizações não governamentais, mas também porque naquele momento elas representavam uma importante base de sustentação do governo. É preciso ter em mente que com a instabilidade política que marcou o período da Assembleia, dificilmente teria sido possível aprovar o novo texto constitucional se não fosse pela forte mobilização dos movimentos sociais. Formou-se então uma forte aliança entre o governo, representado pelo MAS na Assembleia, e as organizações indígenas e camponesas. Um assessor do Conamaq, ao tratar do porquê da demanda de reconhecimento na Constituição das 16 nações indígenas do Altiplano boliviano não ter sido atendida no momento de redação da nova constituição, explica:

O Conamaq não recebeu apoio por parte do governo. Também foi uma jogada. Deixaram tudo pra depois da Assembleia Constituinte. Primero derrotemos a direita. Primeiro derrotemos... Tudo era derrotar a direita. Então o Conamaq para não levar a Assembleia Constituinte ao fracasso, teve que ceder muitas vezes. Primeiro foi a representação direta, teve que ceder o reconhecimento dessas nações, tudo aquilo. Então, as nações originárias não estão discriminadas ${ }^{142}$.

A fala do assessor do Conamaq aponta a forte polarização política que marcou o período da Assembleia Constituinte e influenciou as relações entre as organizações do Pacto de Unidade e entre estas e o MAS.

Os primeiros seis meses de trabalho dos constituintes foram dedicados à elaboração do estatuto que deveria reger o trabalho da Assembleia. Um ponto central da disputa entre os partidos aliados ao governo e as forças políticas de oposição se referia

\footnotetext{
${ }^{142} \mathrm{Na}$ atual Constituição boliviana, são reconhecidas além do espanhol, 36 línguas originárias como línguas oficiais do Estado. Em nenhuma parte da Constituição estão indicados os povos e nações indígenas que formam o Estado Plurinacional. Esta descrição, com o reconhecimento das 16 nações do Altiplano, que falam aymara e quéchua, era uma reivindicação do Conamaq durante a Assembleia Constituinte. Entrevista realizada em La Paz, setembro de 2012.
} 
aos votos necessários para a aprovação do novo texto. O Podemos defendia que a aprovação de todos os artigos deveriam dar-se por dois terços dos votos, proposta à qual se opunha o MAS. Esse impasse chegaria ao fim somente em 14 de fevereiro de 2007, com um acordo aprovado por 201 constituintes, que estabelecia que os informes das comissões e o texto constitucional seriam aprovados "em grande" por maioria absoluta, e a sua revisão "em detalhe", ou seja, de cada artigo individualmente, deveria seria aprovada por no mínimo dois terços dos constituintes. Se não fosse aprovado, o texto seria revisto por representantes dos partidos e das comissões em busca de acordo para, em seguida, ser novamente colocado em votação. Caso algum tema não alcançasse a aprovação por dois terços, um referendo seria realizado (Albó, Carrasco, 2008). Como veremos adiante, estas regras teriam grande influência no cálculo dos atores que participavam do processo constituinte.

Nos últimos meses de 2006, com os trabalhos da Assembleia parados em torno desse impasse, a articulação das organizações sociais em torno da proposta do Pacto de Unidade tampouco avançava. Em janeiro de 2007, começaram a funcionar as 21 comissões, com representantes eleitos dos diferentes partidos, dedicadas ao debate de temas centrais a serem abordados pelo novo texto constitucional: 1 Visão de País; 2 Cidadania, Nacionalidade e Nacionalidades; 3 Deveres, Direitos e Garantias; 4 Organização e Estrutura do Novo Estado; 5 Legislativo; 6 Judicial; 7 Executivo; 8 Outros Órgãos do Estado; 9 Autonomias Departamentais, Provinciais, Municipais e Indígenas, Descentralização e Organização Territorial; 10 Educação e Interculturalidade; 11 Desenvolvimento Social Integral; 12 Hidrocarbonetos; 13 Mineração e Metalurgia; 14 Recursos Hídricos e Energia; 15 Desenvolvimento Produtivo Rural Agropecuário e Agroindustrial; 16 Recursos Naturais Renováveis, Terra Território e Meio Ambiente; 17 Desenvolvimento Amazônico; 18 Coca; 19 
Desenvolvimento Econômico e Finanças; 20 Fronteiras Nacionais, Relações Internacionais e Integração; 21 Segurança e Defesa Nacional.

As comissões deveriam representar espaços de diálogo e geração de consenso em torno dos artigos que seriam apresentados na plenária da Assembleia. Embora tal consenso dificilmente fosse alcançado com a oposição, as comissões constituíram um importante espaço de atuação de autoridades e assessores do Pacto de Unidade.

Além do trabalho de autoridades e assessores do Pacto de Unidade nas 21 comissões, foi criado um espaço para articular as propostas das organizações sociais e do MAS, o "grupo dos 12". Esse grupo era formado curiosamente por 16 membros, dentre os quais sete representantes do Poder Executivo; 2 da Cidob; 2 da Federação de mulheres camponesas (FNMCB-BS), as Bartolinas; 2 da CSUTCB; 1 do Conamaq; 1 da confederação de colonizadores (CSCB); e 1 da Representação Presidencial para a Assembleia Constituinte (Repac) (Garcés 2010b: 60) ${ }^{143}$. Em determinados temas que eram importantes no Projeto do Pacto de Unidade, como a criação do quarto poder (um poder social de controle dos outros poderes), ou em questões relacionas aos direitos territoriais dos povos indígenas e a propriedade dos recursos naturais, não havia consenso entre os representantes das organizações, do governo e do MAS (Valencia, Égido, 2010: 100). Ainda assim, em alguns desses casos, a construção de uma proposta comum foi possível, às vezes com intervenção direta do presidente Evo Morales (ibid.). Garcés afirma que ainda que o trabalho do "grupo dos 12" tenha permitido uma "retroalimentação permanente" entre seus membros e a equipe técnica que trabalhava com as comissões da Assembleia em Sucre, a criação deste grupo havia sido uma estratégia do Executivo para controlar o processo do Pacto de Unidade (2010b: 61). A

143 "Em novembro de 2006, o presidente Evo Morales anunciou que a proposta de Constituição do MAS sairia do trabalho de uma equipe formada por quatro representantes do Poder executivo, quatro constituintes de sua bancada e quatro das organizações sociais". Por este motivo, a equipe a qual me referio foi chamada de "o grupo dos 12" (Garcés 2010b: nota 35). 
tentativa de "cooptação" do Pacto pelo MAS durante o período da Assembleia Constituinte foi igualmente apontada por um ator que trabalhava como assessor do Conamaq naquele momento ${ }^{144}$. Por outro lado, Garcés destaca a influência positiva dos representantes do Pacto nos debates do "grupo dos 12", que resultou na aceitação de propostas importantes para as organizações indígenas, como o Estado Plurinacional, a propriedade dos recursos naturais para o povo e não o Estado e as autonomias indígenas (ibid.: 84). Nesse período, o presidente Evo Morales esteve diretamente envolvido no debate que acontecia em Sucre (ibid.: 85).

Nos primeiros meses de 2007, ao mesmo tempo em que se reunia o "grupo dos 12", manteve-se, sob a liderança da CPESC, o trabalho de uma equipe técnica e de mesas de trabalho para o refinamento das principais propostas do Pacto de Unidade. O resultado desse trabalho teve influência na elaboração da proposta final discutida pelo Pacto em março de 2007, com base no texto elaborado pelo grupo dos 12 (Valencia, Égido, 2010: 100). Essa nova proposta seria trabalhada por representantes do Pacto que acompanhavam as discussões em diferentes comissões.

Assim, a proposta final do Pacto de Unidade foi elaborada tendo em conta a importância da aliança entre suas organizações sociais e o partido do governo, mas, igualmente, em um contexto de polarização política.

\subsection{A polarização política durante o processo constituinte}

O período da Assembleia Constituinte foi marcado por uma grande instabilidade política e fortes enfrentamentos entre o governo e a oposição. $\mathrm{Na}$ interpretação de Carlos Böhrt, senador pelo Podemos no momento da Assembleia Constituinte, "foi a

\footnotetext{
${ }^{144}$ Entrevista realizada em La Paz, outubro de 2012.
} 
partir do seio da Assembleia Constituinte que se gerou e espalhou pelo país a maior polarização política registrada nas duas ou três últimas décadas, determinando que o projeto de uma nova Constituição estivesse no centro dos conflitos” (Böhrt, 2009: 50, tradução minha). Sobre o processo constituinte, Samuel Doria Medina, líder da Unidad Nacional, partido opositor ao MAS, aponta:

Quando chegamos à Assembleia Constituinte encontramos dois extremos: um setor das regiões, que foi sabotar a Assembleia Constituinte. Impressionou-me bastante um velho político de quem um dia escutei o mesmo que escutei ou li sobre os alcoólatras. Um alcoólatra em processo de recuperação diz: ,hoje ganhei um dia sem álcool, verei amanhãee Este político, fazendo jogo de palavras, dizia: ,hoje sabotamos a Assembleia, veremos amanhãee (...) Também havia outro grupo radical, fundamentalmente gente do trópico cochabambino, que não queria escutar, queria a imposição de seus planos (entrevista publicada em Peñaranda, 2009: 120, tradução minha).

Apesar das diferenças entre os grupos de oposição ao governo Evo Morales presentes na Assembleia Constituinte, Iamamoto indica a existência de um certo consenso entre as posições políticas do bloco opositor. Tal consenso estava relacionado à crítica ao centralismo estatal, à defesa das autonomias departamentais e à necessidade de um acordo amplo em torno do texto constitucional (2011: 92). Ao longo do processo de elaboração da Constituição, o Podemos apresentaria os maiores obstáculos para a construção de um texto de consenso e, inclusive, para o próprio funcionamento da Assembleia Constituinte.

O processo de crise política que havia iniciado nos anos anteriores teve grande influência no desenrolar dos debates que ocorriam na cidade de Sucre. Como vimos, os debates em torno da elaboração do regimento da Assembleia consumiram os primeiros meses de trabalho dos constituintes. As divergências em torno da natureza da Assembleia, originária ou derivada, e do número mínimo de votos para a aprovação do 
novo texto não apenas refletiam a forte polarização entre o bloco aliado ao governo e a oposição, mas, indicavam igualmente, lutas pelos limites dentro dos quais deveria darse a refundação do Estado boliviano. Aqueles que defendiam a natureza originária da Assembleia e a aprovação do novo texto por maioria absoluta apoiavam uma proposta de mudança de amplo alcance contra a tentativa da oposição de limitar a transformação da ordem política vigem até aquele momento. Além dos partidos e agrupações de cidadãos presentes em Sucre, os governadores (prefectos) dos departamentos da Meia Lua insistiam na necessidade de aprovação da Constituição por dois terços dos votos.

Em setembro de 2006, as organizações do Pacto de Unidade se declararam em estado de emergência e convocaram as organizações de base a formarem comitês de defesa da constituinte, frente a "qualquer tentativa de boicote ou sabotagem" do processo (Garcés, 2010b: 53).

Em dezembro de 2006, o impasse criado demandou um processo de negociação coordenado pelo presidente Evo Morales entre a mesa diretora da Assembleia, os delegados dos comités cívicos departamentais e os chefes de representações políticas (Albó, Carrasco, 2009). Como forma de pressão, constituintes do Podemos, MNR, Camino al Cambio e Autonomía para Bolivia (APB) iniciaram uma greve de fome em defesa dos dois terços (ibid.).

Uma vez aprovados o caráter originário da Assembleia e a regra dos dois terços para votação do novo texto, iniciou-se um trabalho de concertação por parte do MAS para que a constituição em elaboração pudesse alcançar o apoio necessário para sua aprovação.

Frente ao risco de que os acordos políticos excluíssem importantes demandas do movimento indígena, a Cidob organizou, em julho de 2007, a "VI Marcha indígena pelas autonomias indígenas, terra e território e pelo estado plurinacional”. Esse 
episódio, assim como uma mobilização anterior organizada pelos guaranis para a inclusão de suas propostas sobre autonomia indígena nos informes da comissão de autonomias, mostram que, ainda que a Assembleia Constituinte tenha aberto o campo político institucionalizado para atores até então excluídos, esta abertura foi limitada. Para muitos, o espaço da política continuava sendo as ruas e estradas do país.

A declaração da VI Marcha iniciava-se da seguinte forma:

Os 34 povos indígenas do Oriente, Chaco e da Amazônia, frente ao perigo eminente de que nossas demandas e propostas históricas não sejam incluídas plenamente nos informes das Comissões da Assembleia Constituinte, decidimos, por vontade política própria, empreender a VI MARCHA INDIGENA em direção a Sucre como um conjunto de ações, dentre as quais se destacam a vigília permanente ao trabalho das comissões da Assembleia Constituinte em Sucre, o Cabildo Indígena pelas AUTONOMIAS INDÍGENAS realizado na Chiquitania, no final de junho de 2007, o bloqueio da estrada Santa Cruz - Yacuiba pelos nossos irmãos guaranis da APG e outras medidas executadas para exigir a incorporação de nossas demandas históricas em tais informes ${ }^{145}$.

Haveria conflitos importantes entre algumas organizações do Pacto de Unidade e o MAS durante os trabalhos da Assembleia Constituinte; e, durante a VI Marcha Indígena, as divisões dentro do Pacto de Unidade são evidentes. Por um lado, o Conamaq se mobilizou em Sucre em apoio à marcha da Cidob, por outro, as organizações camponesas coincidiam com o governo nas críticas à mobilização. Valencia e Égido afirmam que a marcha foi iniciada sem consenso mesmo entre os indígenas das Terras Baixas, já que a CPESC duvidava de sua pertinência e da força das bases para essa mobilização (2010: 107). Schavelzon explica que ainda que os temas exigidos pelos indígenas organizados fossem recusados principalmente pela oposição, o

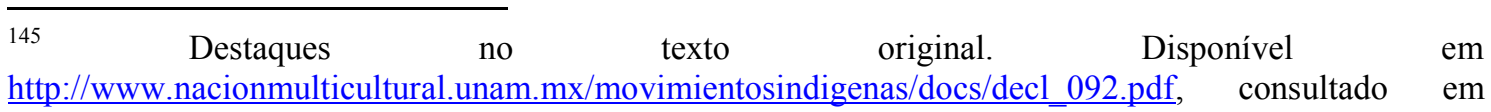
12/04/2014, tradução minha. 
MAS igualmente "manifestava suas dúvidas ou, na procura do consenso, deixava cair especialmente os temas reivindicados pelos indígenas" (2010: 162). O autor acrescenta que, como consequência da marcha, foi reduzida a participação das Terras Baixas na elaboração do projeto do MAS (ibid.).

Formadas por forças políticas da base do governo e da oposição, a maioria das comissões não chegou a um consenso quanto às propostas para a nova Constituição. Dessa forma, foram elaborados separadamente informes de maioria e de minoria. A norma dizia que no caso dos artigos que não serem aprovados por dois terços dos votos, seria realizado um referendo para consultar a população (Schavelzon, 2010).

Como estratégia de boicote do trabalho realizado pelos constituintes, parte da oposição adotou como bandeira a defesa de Sucre como "capital plena” da Bolívia. Essa proposta havia sido apresentada, em novembro de 2006, por um membro do Podemos e tomou projeção a partir da Comissão de Autonomias. Em meados de 2007, a oposição condicionou a apresentação nas sessões plenárias dos informes elaborados pelas comissões, à aprovação da transferência dos poderes do Estado para Sucre (Valencia, Égido, 2010: 114). Grandes mobilizações foram organizadas na cidade a favor desta reivindicação.

Em agosto de 2007, o Podemos tentou articular um bloco de apoio, com os governadores e partidos de oposição, para a aprovação de uma constituição paralela (Albó, Carrasco, 2009). Esta proposta apresentaria os temas de desacordo com a base governamental, como a transferência dos poderes para Sucre, as autonomias departamentais e indígenas e a relação entre justiça comunitária e justiça indígena (ibid.).

Frente ao impasse no qual se encontrava a Assembleia Constituinte e possibilidade iminente de fracasso, em setembro, organizações camponesas se dirigem a 
Sucre e inicia-se um processo de diálogo em La Paz, sob a coordenação do vicepresidente García Linera. Essa Cúpula Política contou com a presença de 16 forças políticas, representadas por constituintes e líderes partidários (Schavelzon, 2010: 235). Contudo, o acordo alcançado não foi assinado pelo Podemos.

Como resultado do encontro em La Paz, foi criada a Comissão de Diálogo e Consenso e a Comissão de Coordenação Política (Albó, Carrasco, 2009). Nos acordos com a oposição, buscava-se construir consenso sobre diferentes temas, com o objetivo de alcançar os dois terços dos votos necessários para a aprovação da Constituição (Schavelzon, 2010: 241). As organizações indígenas do Pacto de Unidade mostraram-se insatisfeitas com os resultados dos acordos. ",Pouco a pouco foram cedendo em tudo", dizia na mesma nota Justino Leaños, dirigente do Conamaq, que falava em "traição" do MAS" (ibid.: 243). Schavelzon afirma que, além de infrutífera, a tentativa de negociação com a oposição "debilitou as bases sociais do MAS, principalmente das organizações indígenas que viram cair por terra algumas de suas reivindicações” (ibid.: 270).

Ao mesmo tempo, a crescente radicalização das mobilizações pela transferência de todos os poderes para Sucre impediam que ocorressem as sessões plenárias da Assembleia. Foram organizadas passeatas, greves de fome e piquetes na porta do Teatro Gran Mariscal, onde os constituintes deveriam se reunir. A estas manifestações, somaram-se eventos de discriminação e violência contra constituintes indígenas. Em resposta, indígenas e camponeses se encaminharam a Sucre para garantir a continuidade da Assembleia. Esta mobilização, formada principalmente por organizações de El Alto e camponeses de Chuquisaca e Potosí, garantiu a aprovação do texto constitucional "em grande", no dia 24 de novembro de 2007, no Liceu Militar La Glorieta, longe do centro de Sucre. A aprovação ocorreu sem a presença da oposição, com 145 constituintes 
reunidos no Liceu, quase todos da bancada do MAS e forças aliadas, sob a proteção da polícia, exército e dos movimentos sociais (Albó, Carrasco, 2009).

Schavelzon (2010) descreve cenas de batalha em torno da aprovação da Constituição. Manifestantes enfrentavam a polícia e ateavam fogo em pneus que eram lançados dentro do Liceu. O novo texto constitucional foi aprovado "em grande", mas os constituintes estavam sitiados. Alguns tentavam sair escondidos atravessando o rio e pelas montanhas, enquanto estudantes tentavam invadir o Liceu. Um dos constituintes, Félix Cárdenas, atualmente vice-ministro de descolonização, foi interceptado e torturado por grupos a favor da "capital plena" (ibid.: 321). A sede da polícia e a casa do governador de Chuquisaca foram incendiadas e a polícia abandonou a cidade ${ }^{146}$. Três pessoas morreram (ibid.).

Duas semanas depois da aprovação no Liceu, impedidos de se reunirem novamente em Sucre, os constituintes aprovaram o texto constitucional "em detalhe" no dia 8 de dezembro, na cidade de Oruro. A plenária em Oruro contou com a presença de 164 constituintes, incluindo representantes do opositor Unidad Nacional (UN) e do MNR, que não haviam participado da aprovação no Liceu (Albó, Carrasco, 2009). A leitura dos 411 artigos, agrupados em quatro blocos, foi seguida de breve debate. A questão da transferência dos poderes para Sucre ainda causava desacordos (ibid.). A UN apresentou observações a 20 artigos, mas, finalmente, apenas um artigo, sobre o limite máximo da propriedade rural, não alcançou os dois terços dos votos dos constituintes presentes (ibid.) ${ }^{147}$. Schavelzon indica que os números da votação em Oruro não haviam mudado de forma significativa em relação ao número de votos inicias com que contava a proposta de Constituição do MAS, "mostrando até que ponto o destino da Assembleia

\footnotetext{
${ }^{146}$ O governador Sánchez era do MAS, no entanto, dada a forte pressão popular em seu departamento, havia apoiado a demanda da capital plena.

${ }^{147}$ Alguns artigos foram adiados para serem debatidos na Comissão de Acordo (Schavelzon, 2010: 344).
} 
tinha sido em boa medida selado com a lei de convocatória de março de 2006" (2010: 339). Essa versão, que será modificada no ano seguinte em negociações com a oposição e no Congresso boliviano, ficou conhecida como a "Constituição de Oruro".

\subsection{A crise política se manifesta em diferentes partes do país}

Além dos graves conflitos em torno da transferência dos poderes do Estado para Sucre, outros eventos indicam que a polarização política no interior da Assembleia Constituinte era um reflexo da crise política maior. A polarização não se limitava ao campo político partidário, com o enfrentamento entre representantes da oposição no Senado e governadores dos departamentos da Meia Lua com o governo. O confronto entre aqueles que representavam a antiga ordem e os que haviam se mobilizado contra esta na primeira fase de crise política (2000-2005) dava-se também nas ruas.

Assim, em outubro de 2006, realizou-se a V Marcha Indígena pela recuperação dos territórios indígenas e a modificação da Lei Inra. A marcha foi organizada para pressionar o Senado, onde a oposição tinha maioria, para aprovar a Lei de Recondução Comunitária da Reforma Agrária, proposta pelo Executivo. A lei fazia parte de um processo de reestruturação da estrutura fundiária que havia sido iniciado com a promulgação de Decretos Supremos que destinavam as terras fiscais, de forma exclusiva, às comunidades indígenas e camponesas, e indicavam necessidade de urgência na conclusão do processo de titulação de propriedades agrárias ${ }^{148}$. A nova lei elaborada pelo Executivo, e que visava modificar a Lei Inra, não contava com o apoio das forças de oposição nem com os setores empresariais agrícolas. A partir das modificações, caracterizava-se melhor a questão da função econômica e social da terra,

\footnotetext{
${ }^{148} \mathrm{http} / / /$ www.gobernabilidad.org.bo/piocs/tierra-y-territorio/quinta-marcha-nacional,$\quad$ consultado em $13 / 04 / 2014$
} 
possibilitando a conversão de terras improdutivas em terras fiscais (Iamamoto, 2010: 53). Finalmente, a mobilização social foi bem sucedida e, depois de meses de boicote ao projeto de lei, o Senado se viu obrigado a aprová-lo.

Em outros episódios, a polarização política se deu de forma violenta. Em dezembro de 2006, houve uma onda de violência contra organizações indígenas chiquitanas. Foi incendiada a sede da Central Indígena Paikoneca de San Javier (CIPSJ), foi depredada a sede da Central Indígena de Concepción (CICC); dirigentes da Central Indígena de San Miguel e San Rafael sofreram agressões físicas e tiveram bens destruídos (Valencia, Égido, 2010: 112). Além disso, nos mercados de municípios de Santa Cruz, imigrantes indígenas do Altiplano foram agredidos e tiveram seus postos de venda destruídos (ibid.).

Entretanto, a violência decorrente da polarização política não se limitava aos departamentos da Meia Lua. Em janeiro de 2007, por exemplo, organizações sociais camponesas e urbanas ocuparam as ruas da cidade de Cochabamba em protesto à medida anunciada pelo governador Manfred Reyes Villas de desconhecer os resultados do referendo de 2006 , no qual $63 \%$ da população do departamento havia votado contra a autonomia departamental. Jovens, sobretudo de setores urbanos, atacaram com pedras, ferros e, em alguns casos, armas de fogo, aqueles que protestavam (Espósito, 2010: 8). Três pessoas morreram e mais de quatrocentas ficaram feridas ${ }^{149}$. Espósito interpreta os eventos de 11 de janeiro em Cochabamba como uma reatualização do discurso sobre limpeza, que durante a formação da cidade havia marcado a separação entre citadinos e camponeses. Neste sentido, para a autora, "a ocupação da cidade por camponeses era uma ruptura da fronteira imaginada que separa e diferencia o campo da cidade, que

\footnotetext{
${ }^{149}$ Fonte: Comisión Interinstitucional de Derechos Humanos Cochabamba, http://redunitas.org/boletin/01 enero10/12atresanios.php, consultado em 10/04/2014.
} 
separa o „,eio ${ }^{\text {ee }}$ do „belo ${ }^{\text {ee }}$, os „,costumes selvagens ${ }^{\text {ee }}$ dos „,ivilizados ${ }^{\text {ee }}$, a „sujeira ${ }^{\text {ee }}$ da „limpeza"ee" (ibid.: 13).

Diferentes episódios de racismo em Sucre também reproduziam, de alguma forma, o "estranhamento" que aparece na análise de Espósito sobre Cochabamba, entre os moradores da chamada "cidade branca", de arquitetura colonial e ares aristocráticos, e a população camponesa e indígena que ali estavam para contribuir na elaboração da nova Constituição. Há vários relatos de racismo contra os constituintes indígenas, aos quais era negado o acesso a determinados hotéis e restaurantes da cidade, e que em diferentes momentos foram agredidos física e verbalmente.

Em novembro de 2007, foi organizada a Marcha pela Renta Dignidad e pela defesa do texto constituinte aprovado no Liceu Militar de Sucre. Partidos de oposição no Senado e os governos dos departamentos da Meia Lua se posicionaram contra a proposta do Executivo nacional de criação de uma bonificação mensal para todos os bolivianos acima dos 60 anos, a chamada renta dignidad, com parte dos recursos dos hidrocarbonetos ${ }^{150}$. O benefício foi finalmente aprovado pela Câmara Alta depois que a marcha, na qual participaram cocaleiros e Ponchos Rojos, chegou à La Paz e cercou o Palácio Legislativo ${ }^{151}$.

Como vimos, ao longo de 2006 e 2007, as organizações indígenas e camponesas adotaram diferentes estratégias para garantir o funcionamento da Assembleia Constituinte e também para que suas propostas fossem incluídas na nova Constituição, além de garantir a implantação de programas políticos, enquanto o bloco do governo buscava negociar com uma oposição que parecia ter como principal objetivo a inviabilização do processo constituinte. Esse contexto político apresentava

\footnotetext{
${ }^{150} \mathrm{http}: / /$ www.bolpress.com/art.php?Cod=2007112701, consultado em 10/04/2014.

${ }^{151}$ http://www.pagina12.com.ar/diario/ultimas/20-95392-2007-11-28.html, consultado em 10/04/2014.
} 
possibilidades ambíguas para as organizações do Pacto, principalmente para aquelas que não integravam o MAS. Se, por um lado, a necessidade de negociação com a oposição limitava o alcance da mudança ambicionada pelas organizações indígenas, por outro lado, a instabilidade política instigada pela oposição fazia das organizações do Pacto aliados indispensáveis ao governo, que se via obrigado a ter sempre em conta suas demandas.

\subsection{A autonomia indígena: da demanda histórica ao reconhecimento constitucional}

Se, por um lado, a história dos indígenas na Bolívia foi marcada pela opressão, ela é também uma história de resistência que, muitas vezes, esteve associada à construção do autogoverno indígena ou à luta pelo seu reconhecimento.

Foram muitos os levantes indígenas contra a ordem opressora, desde a conquista espanhola. Durante o século XVIII, destacam-se, na região do Chaco, a revolta de milhares de indígenas, sob a liderança de Juan Bautista Aruma, em 1727, e a mobilização da década 1770. A década seguinte foi marcada por importantes levantes nas Terras Altas: a expulsão de autoridades do governo espanhol e a formação de um governo autônomo em Jesús de Machaca, na província de Pacajes; a rebelião liderada por Tomás Katari, na região de Chayanta, no departamento de Potosí; e a mobilização de dezenas de milhares de indígenas que, liderados por Tupac Katari e Bartolina Sisa, cercaram por meses a cidade de La Paz.

Os indígenas continuaram a sublevar-se em diferentes partes do território boliviano durante o período da colônia. Sobre as rebeliões indígenas ocorridas entre 1771 e 1781, no Altiplano, Thomson indica a existência de diferentes opções políticas 
anticoloniais até 1781: "a eliminação radical do inimigo colonial; a autonomia regional indígena que não necessariamente representava um desafio para a coroa espanhola; e a integração étnica/racial sob hegemonia índia" (2011: 71, tradução minha).

O período republicano, iniciado após a Independência da Bolívia, em 1825, foi igualmente marcado por importantes sublevações indígenas. Em 1892, foi organizada a insurreição guarani, liderada por Apiaguaiki Tumpa, que culminou na Batalha de Kuruyuki, na qual os guaranis foram massacrados por tropas governamentais. Poucos anos mais tarde, o aymara Pablo Zarate Willka comandou um exército indígena no Altiplano. Este exército iria aliar-se aos federalistas/liberais na guerra contra os conservadores. Sobre a participação indígena na Guerra Federal (1898-1899), Silvia Rivera aponta:

A rebelião de Willka antecipa e coloca em evidência o caráter falaz da proposta liberal. Ainda que os rebeldes tenham participado do bando liberal durante a primeira fase da guerra civil, não tardaram em desenvolver objetivos autônomos, nem sempre apresentados de forma explícita. Seu programa de reivindicações pode ser sintetizado em quatro pontos: restituição das terras usurpadas das comunidades; luta defensiva contra a agressão do criollaje latifundiário; desconhecimento das autoridades liberais e conservadoras sobre as tropas índias; e constituição de um governo índio autônomo sob a autoridade de seu líder máximo (2003 [1984]: 72, tradução minha).

Nas primeiras décadas do século $\mathrm{XX}$, novas rebeliões indígenas foram desencadeadas. Mais uma vez, Jesús de Machaca (1921) e Chayanta (1927) se levantaram. Hylton et al. observam nessas mobilizações, assim como naquelas ocorridas em Pacajes, em 1914 e Ayopaya, em 1947, lutas para a obtenção de uma autonomia local-regional (2011:16). Estaban Ticona (2003) aponta que no final do século XIX, começou-se a elaborar uma demanda pelo direito à autonomia por parte de ayllus e comunidades aymaras e quéchuas. O autor afirma que a formação do primeiro governo 
indígena, no departamento de Oruro, por volta de 1900, não seria "uma causalidade do momento, mas uma consequência de uma etapa de forte convicção indígena de buscar seu autogoverno" (ibid.: 2, tradução minha).

É interessante notar que Jesús de Machaca, Chayanta e Charagua (onde ocorreu uma revolta indígena no século XVIII) estão atualmente entre os onze municípios em processo de conversão à autonomia indígena originário camponesa. Esta informação parece corroborar a seguinte percepção Maximo Quisbert sobre a autonomia como uma luta antiga dos povos indígenas:

O processo histórico teve diferentes matizes, nem sempre com esse nome, mas com os mesmos objetivos de consagrar os direitos políticos e sociais. A autonomia indígena constitui a memória histórica dos povos, por isso, em diferentes momentos de luta dos povos, aparece como demanda específica, outras vezes como demanda ambígua, mas está sempre presente como projeto político para mudar a condição de vida social dos povos indígenas (2009: 136-7, tradução minha).

Dentre as demandas presentes nas propostas de constituição elaboradas pelo Pacto de Unidade estava a autonomia indígena. Para Chávez Léon (2008), o projeto de autonomia indígena apresentado pelos movimentos indígenas na Assembleia Constituinte, em 2006, era uma estratégia defensiva, uma resposta às demandas por autonomia departamental dos governos do Oriente boliviano. A autora retoma as propostas da CSUTCB, da Cidob e do Conamaq até aquele ano e destaca que o projeto anterior da Cidob tratava de uma autonomia de gestão dos recursos e de território e que a CSUTCB defendia, igualmente, um projeto de autonomia de gestão, até o "avanço da direita". O exame de Schilling-Vacaflor (2008) coincide em parte com a de Chávez Léon. Para a primeira, durante a Assembleia Constituinte, o projeto de autonomia indígena para a CSUTCB tinha um papel estratégico para contrapor os projetos de 
autonomia departamental. Para o Conamaq e a Cidob, contudo, a autonomia indígena representaria um objetivo importante em si, afirma.

A atual ministra de autonomias Claudia Peña fala sobre a existência de "profundas raízes históricas das autonomias indígenas" ${ }^{152}$. Em diferentes entrevistas com representantes das organizações indígenas e representantes dos municípios atualmente em conversão à autonomia indígena originário camponesa, surge a ideia de que, ao mesmo tempo que sempre foram autônomos, sempre lutaram pela autonomia. Assim, tanto no caso de entrevistados do Conamaq, como de representantes guaranis, foram feitas referências a antigas rebeliões, como aquela liderada por Tupac Katari no Altiplano, ou a Batalha de Kuruyuki, no Chaco, como marcos da luta pela autonomia indígena.

No caso da CSUTCB, documentos elaborados nos primeiros anos de existência da organização faziam referência à questão do autogoverno. Em sua Tese Política, elaborada no II Congresso Nacional da central sindical, em 1983, o termo utilizado na introdução do texto são "autênticas formas de governo próprio":

\begin{abstract}
Nós atuais dirigentes estamos convencidos que não aceitamos nem aceitaremos qualquer reducionismo classista convertendo-nos somente em "camponeses". Tampouco aceitamos ou aceitaremos reducionismo etnicista que converta nossa luta a um confronto de "índios" contra "brancos". Somos herdeiros de grandes civilizações. Também somos herdeiros de uma permanente luta contra qualquer forma de exploração e pressão. Queremos ser livres em uma sociedade sem exploração nem opressão, organizada em um Estado plurinacional que desenvolva nossas culturas e autênticas formas de governo próprio (tradução minha) ${ }^{153}$.
\end{abstract}

Em 1984, a CSUTCB organizou um congresso sobre o tema da reforma agrária. Diferentes comissões de trabalho foram formadas e, a partir de seus debates, foi

\footnotetext{
${ }^{152}$ Entrevista realizada em La Paz, dezembro de 2013.

${ }^{153}$ Destaques meus.
} 
elaborado um projeto de lei agrária. Nesse, no título a respeito das comunidades originárias e reconstituídas, os seguintes capítulos tratam diretamente da questão autonômica:

Artigo 16- As comunidades gozam de autonomia em seu regime interno político, administrativo, sendo regidas por autoridades designadas pela comunidade conforme o costume. O Estado garante o livre e pleno exercício da autonomia.

Artigo 17- As controvérsias de natureza civil, agrária assim como as faltas e delitos originados entre membros da comunidade serão resolvidos ou punidos de forma definitiva pelos órgãos de governo da comunidade, segundo seus costumes, crenças e valores socioculturais (...)

Artigo 18- O exercício da autonomia político-administrativa corresponde às grandes e pequenas comunidades, com a faculdade destas últimas de se reagruparem e formar níveis superiores de organização (tradução minha).

Pablo Regalsky e Francisco Quisbert (2008) associam as demandas de autonomia da CSUTCB aos processos locais, às práticas autônomas apresentadas na introdução deste trabalho. Segundo eles, nos congressos da CSUTCB no final dos anos oitenta, e em um encontro realizado em Corqueamaya, em 1989, houve uma mudança nos discursos sindicais que marcaria o início do debate sobre o significado da reivindicação territorial para as comunidades andinas. Schavelzon aponta que as propostas de autodeterminação e autonomia perante o Estado, que seriam discutidas na Assembleia Constituinte em 2006, já estavam presentes neste encontro (2010: 102). Para Regalsky (2007), os direitos jurisdicionais (territoriais) da comunidade camponesa/indígena seria uma agenda oculta da CSUTCB, da qual não teriam consciência nem os líderes, nem as bases.

Para entender as diferentes explicações apresentadas acima, é preciso ter em conta que as culturas dos movimentos não são estáticas, elas variam de acordo com o 
“lócus" social do movimento e com mudanças no grupo majoritário (McAdam, 1994). Desta forma, ao longo dos seus quase trinta anos de existência até o processo constituinte, a demanda pelo autogoverno indígena variou com os diferentes grupos que estiveram à frente da CSUTCB. Ao mesmo tempo, se as mudanças no interior das organizações sociais podem igualmente refletir transformações no cenário político nacional, é compreensível que no momento em que as organizações camponesas viam o instrumento político que haviam formado ocupar o lugar central do Estado boliviano, a construção de um sistema autônomo a este Estado dificilmente seria uma prioridade.

No caso das Terras Baixas, a Asamblea del Pueblo Guaraní (APG) foi o importante impulsor da demanda de autonomia indígena. Contudo, diferentes atores entrevistados quando questionados sobre quando se começou a falar de autonomia, indicam a Marcha pelo Território e Dignidade de 1990. Eles associam assim a demanda por território à demanda por autonomia, ainda que, possivelmente, o termo "autonomia" ainda não estivesse presente. Para Ströbele-Gregor (1994), duas iniciativas governamentais na década de noventa teriam acelerado o desenvolvimento de conceitos políticos autônomos das organizações das Terras Baixas: o projeto da Lei Índia e a descentralização administrativa estatal. Para evitar que a nova Lei Índia fosse favorável aos interesses capitalistas dominantes, organizações indígenas, dentre elas a Cidob, formularam um projeto legal próprio. Segundo a autora, dentre as principais reivindicações das organizações estavam o direito dos grupos étnicos sobre os seus territórios e autonomia em relação ao estado-nação (ibid.).

No caso dos representantes do Conamaq entrevistados, para estes a luta pela reconstituição das autoridades comunais é associada à luta pela autonomia. Como explica a seguinte fala do Tata Mallku então responsável por terra e território: “Quando surge a reconstituição, sempre falavam de autonomia, para autogovernarmos, para 
autodeterminarmos" ${ }^{154}$. Um antigo assessor desta organização me explicou que no começo da organização não se falava em autonomia, mas em "reconstituição de território"155. Em seguida, o tema teria sido "reconstruir autoridades", "retirando o sindicato e posicionando os mallkus [autoridades indígenas masculinas]". O ator entrevistado desenha em meu caderno de campo o seguinte esquema, que deixa muito claro o seu entendimento sobre o projeto de reconstituição do Conamaq:

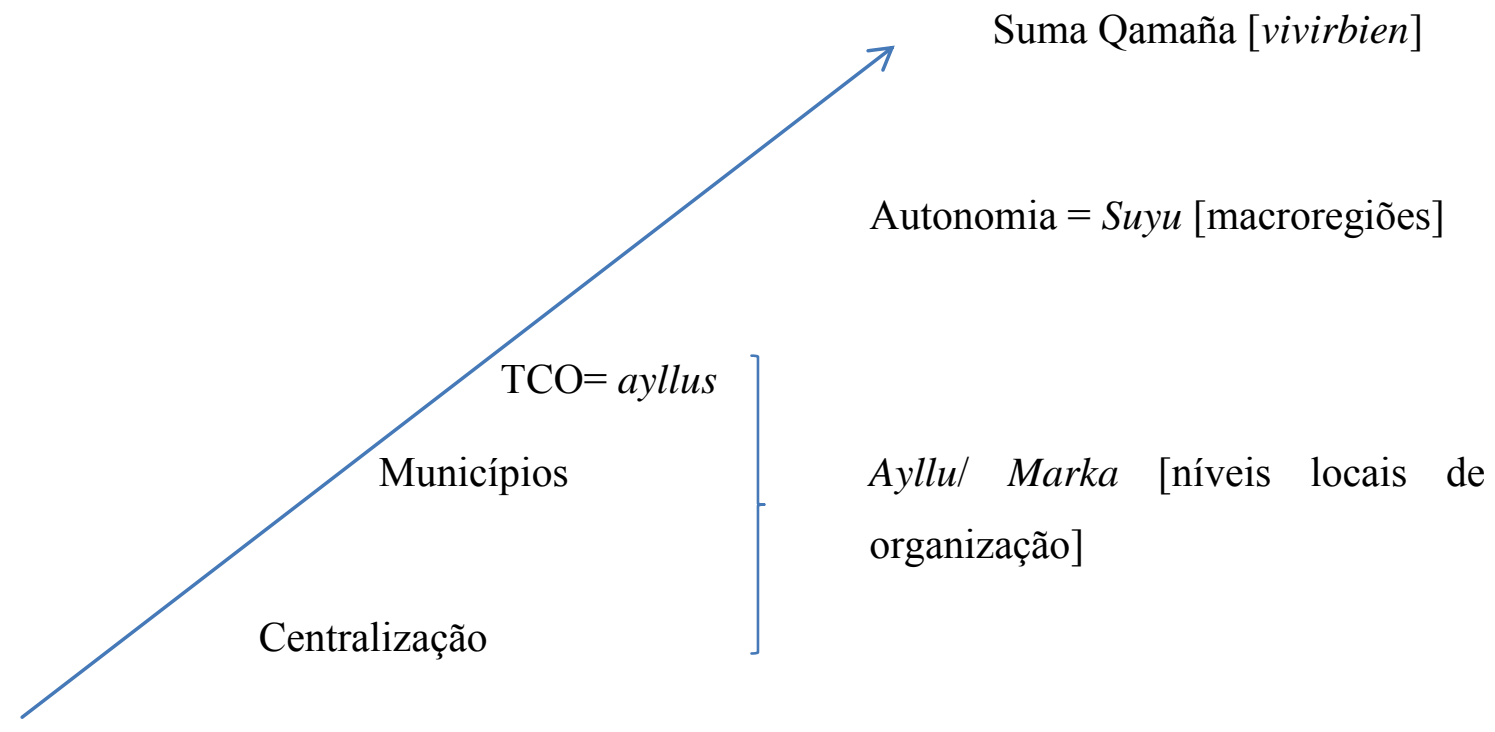

Exclusão

Explicando o seu esquema, o antigo assessor afirma que primeiro a reconstituição era pensada para os ayllus, ou seja, as comunidades e, em seguida, para

${ }^{154}$ Entrevista realizada em La Paz, outubro de 2012.

Para Silvia Rivera, os organismos étnicos criados na década de noventa, como o Conamaq, e suas relações com o Estado, através da presença indígena em determinados espaços de poder estatais, e a cooperação internacional, tiveram como consequência uma importante mudança na "consciência étnica da região andina": o movimento indígena passa a adotar uma "lógica de minoria", diferente da "lógica de maioria" anteriormente existente. A nova lógica, segundo a socióloga, era "funcional às reformas liberais que acompanharam o ajuste estrutural" (2007: 104, tradução minha).

${ }^{155}$ Entrevista realizada em La Paz, outubro de 2012. 
as markas. E que apenas lugares mais radicais apontavam para a reconstrução do suyu, (como foi o caso de Jach'a Carangas). Mas a reconstrução dos suyus, como fica claro neste esquema, seria o fim último da autonomia. Entretanto, o entrevistado critica "um grupo radical" que quer a reconstrução do suyu agora, sem tomar em conta que se trata de um processo de longo prazo e que, primeiro, "é preciso ter uma institucionalidade". E, acrescenta que a Bolívia tem que entender que divisões coloniais (categorias coloniais) dividiram as comunidades.

As diferenças entre os processos de reivindicação territorial e de autonomia dos grupos indígenas das Terras Baixas e das Terras Altas - o primeiro partindo da necessidade de garantir o controle territorial frente a diferentes pressões externas e, o segundo, que teve como ponto de inflexão a reconstituição das autoridades indígenas originárias - é perfeitamente compreensível se temos em vista as diferenças históricas, demográficas e de formas de organização social entre povos das Terras Baixas e as populações quéchuas e aymaras apresentadas anteriormente.

De acordo com uma antiga assessora do Pacto, a autonomia indígena foi um consenso construído a partir das demandas de soberania como povos, dos indígenas das Terras Altas e a reivindicação de administração territorial, das organizações das Terras Baixas $^{156}$. Segundo Gonzalo Vargas, atual vice-ministro de Autonomias Indígenas e membro da equipe técnica de apoio do Pacto de Unidade, na Assembleia Constituinte, teriam convergido as visões das Terras Altas e das Terras Baixas ${ }^{157}$. Ele explica que no primeiro caso, não se estabelece delimitações territoriais, já que se trata de fronteiras culturais ${ }^{158}$. Para a segunda visão, onde "o tema territorial emerge de maneira mais

\footnotetext{
${ }^{156}$ Entrevista realizada em La Paz, outubro de 2012.

${ }^{157}$ Entrevista realizada em La Paz, dezembro de 2013.

${ }^{158}$ Lembro que a ocupação de diferentes pisos ecológicos era uma importante característica do padrão de ocupação espacial dos ayllus do Altiplano. Desta forma, o território tradicional dos ayllus dificilmente pode ser demarcado de forma contínua.
} 
nítida", a autonomia passa pelo território. Estes dois elementos, o autogoverno e o território, que começam a se aproximar a partir dos anos 1990, juntos fazem a autonomia. "Esses dois projetos de luta histórica se juntam em uma estratégia de poder. De poder social, de poder dos povos que é chamado autonomia indígena”, afirma.

Ao mesmo tempo, o espaço de negociação entre organizações camponesas e indígenas aberto pelo Pacto de Unidade possibilita a articulação da proposta de Estado Plurinacional, defendida principalmente pela CSUTCB, e a demanda de autonomia indígena. A proposta do Pacto de Unidade entregue aos constituintes em agosto de 2006 aponta o acordo ao qual chegaram as organizações indígenas e camponesas: a formação de um Estado plurinacional e unitário, dentro do qual as autonomias indígenas teriam um lugar central.

Entendemos que o Estado Plurinacional é um modelo de organização política para a descolonização de nossas nações e povos, reafirmando, recuperando e fortalecendo nossa autonomia territorial, para alcançar a vida plena, para "vivir bien", com uma visão solidária, desta maneira, ser os motores da unidade e do bem-estar social de todos os bolivianos, garantindo o exercício pleno de todos os direitos.

\section{$[\ldots]$}

Nossa decisão de construir o Estado Plurinacional baseado em autonomias indígenas, originárias e camponesas deve ser entendida como um caminho em direção à nossa autodeterminação como nações e povos, para definir nossas políticas comunitárias, sistemas sociais, econômicos, políticos e jurídicos e, neste marco, reafirmar nossas estruturas de governo, eleição de autoridades e administração de justiça, com respeito a formas de vida diferenciadas no uso do espaço e do território (Pacto de Unidad, 2006: 4, tradução minha).

Nesta proposta, a autonomia indígena é apresentada da seguinte forma:

A autonomia indígena originária e camponesa é a condição e o princípio de liberdade de nossos povos e nações como categoria fundamental de descolonização e autodeterminação; está baseada em princípios fundamentais e geradores que são os 
motores da unidade e da articulação social, econômica e política no interior de nossos povos e nações e com o conjunto da sociedade. Enquadra-se na busca incessante da construção da vida plena, sob formas próprias de representação, administração e propriedade de nossos territórios (ibid.: 10, tradução minha).

Durante a Assembleia Constituinte, o debate em torno do autogoverno indígena tangenciava muitos debates, como a propriedade dos recursos naturais, o reconhecimento da justiça consuetudinária, dentre outros; fazendo com que a questão da autonomia indígena estivesse presente em diferentes comissões da Assembleia. A Comissão de Autonomias era, contudo, um espaço privilegiado para este debate e, portanto, foi adotado como importante arena para as organizações indígenas e seus assessores em Sucre.

A Comissão de Autonomia mostrou de forma exemplar o embate entre os projetos políticos que haviam levado à crise política nos anos anteriores. De um lado, aqueles que adotaram com força a bandeira da autonomia departamental, contra um governo centralista que, questionado por mobilizações sociais, saía do controle de uma elite política e econômica que até então se confundia com as elites departamentais da Meia Lua, principalmente no caso do departamento de Santa Cruz. De outro lado, estavam organizações populares que haviam participado da contestação da ordem política vigente até 2005 , e que demandavam o reconhecimento do direito ao autogoverno. 
A Comissão de Autonomias era a maior da Assembleia, com 25 constituintes:

\begin{tabular}{|c|c|c|c|c|}
\hline Constituinte & $\begin{array}{l}\text { Agremiação } \\
\text { Política }\end{array}$ & Profissão & $\begin{array}{l}\text { Departamento } \\
\text { pelo qual foi eleito }\end{array}$ & Autoidentifação \\
\hline Saúl Ávalos & MAS & Economista & Santa Cruz & $\begin{array}{l}\text { Não pertence a } \\
\text { nenhum povo } \\
\text { indígena (NP)/ } \\
\text { Mestiço }\end{array}$ \\
\hline $\begin{array}{l}\text { Magda Lidia } \\
\text { Calvimontes }\end{array}$ & MAS & Advogada & Tarija & NP/ Mestiça \\
\hline Severo Aguilar & $\mathrm{MAS}^{159}$ & $\begin{array}{l}\text { Técnico em gestão } \\
\text { municipal e } \\
\text { dirigente } \\
\text { originário }\end{array}$ & Potosí & Quéchua/ Indígena \\
\hline Marcela Revollo & MAS & Socióloga & $\mathrm{La} \mathrm{Paz}$ & NP/ Mestiça \\
\hline Carlos Aparicio & MAS & $\begin{array}{l}\text { Licenciado em } \\
\text { Direito }\end{array}$ & Chuquisaca & Quéchua/ mestiço \\
\hline $\begin{array}{l}\text { Pablo Paul } \\
\text { Zubieta Arce }\end{array}$ & MAS & $\begin{array}{l}\text { Engenheiro e ex- } \\
\text { reitor da UTO }{ }^{160}\end{array}$ & Oruro & $\mathrm{NP} /$ mestiço \\
\hline Francisco Cordero & MAS & Filósofo & La Paz & Aymara/ Indígena \\
\hline Pedro Carvajal & MAS & Advogado & Cochabamba & Aymara/ Mestiço \\
\hline $\begin{array}{l}\text { Nancy Luz } \\
\text { Burgoa }\end{array}$ & MAS & Assistente Social & Potosí & Quéchua/ Mestiça \\
\hline Avilio Vaca & MAS & Agricultor & Santa Cruz & Guarani/Originário \\
\hline Teodoro Acuña & MAS & $\begin{array}{l}\text { Técnico em } \\
\text { administração } \\
\text { municipal }\end{array}$ & Santa Cruz & Quéchua/ Mestiço \\
\hline $\begin{array}{l}\text { María del Rosario } \\
\text { Ricaldi }\end{array}$ & MAS & Advogada & Tarija & NP/ Mestiça \\
\hline $\begin{array}{l}\text { Pedro Lima } \\
\text { Salazar }\end{array}$ & $\mathrm{MAS}^{161}$ & $\begin{array}{l}\text { Filósofo e } \\
\text { advogado }\end{array}$ & Cochabamba & NP/ Mestiço \\
\hline
\end{tabular}

\footnotetext{
159 Nas eleições de 2005, Severo Aguilar havia concorrido ao cargo de deputado uninomial pelo Movimiento Indígena Pachakuti (MIP), fundado por Felipe Quispe. http://www.mirabolivia.com/cons candidato.php?id pers=628, consultado em 17/04/2014.

${ }^{160}$ Universidad Técnica de Oruro.

${ }^{161}$ Declarar-se-ia independente.
} 


\begin{tabular}{|c|c|c|c|c|}
\hline Evaristo Pairo & AYRA & $\begin{array}{l}\text { Engenheiro e líder } \\
\text { comunitários - } \\
\text { Conamaq }\end{array}$ & Oruro & Aymara/ Indígena \\
\hline Félix Vale Veja & MOP & $\begin{array}{l}\text { Engenheiro } \\
\text { Agrônomo }\end{array}$ & Potosí & Quéchua/ Indígena \\
\hline Mario Oña Torres & MBL & $\begin{array}{l}\text { Professor e ex- } \\
\text { presidente do } \\
\text { Comité Cívico }\end{array}$ & Chuquisaca & Quéchua/ Mestiço \\
\hline $\begin{array}{l}\text { José Eduardo } \\
\text { Yañez }\end{array}$ & MNR & Advogado & Beni & NP/ Mestiço \\
\hline $\begin{array}{l}\text { Roy Moroni } \\
\text { Cornejo }\end{array}$ & MNR-FRI & $\begin{array}{l}\text { Comunicador } \\
\text { Social }\end{array}$ & Tarija & NP/ Mestiço \\
\hline $\begin{array}{l}\text { Hugo Gonzalo } \\
\text { Oliva }\end{array}$ & MIR-MN & Advogado & Tarija & Chapaco/ Branco \\
\hline $\begin{array}{l}\text { Hormando Vaca } \\
\text { Diez }^{162}\end{array}$ & AAI & Advogado & Santa Cruz & NP/ Mestiço \\
\hline $\begin{array}{l}\text { Nelson Mariano } \\
\text { Aguilera }\end{array}$ & APB & $\begin{array}{l}\text { Engenheiro } \\
\text { Agrônomo }\end{array}$ & Santa Cruz & NP/ Mestiço \\
\hline $\begin{array}{l}\text { Rubén Darío } \\
\text { Cuellar }\end{array}$ & Podemos & Advogado & Santa Cruz & $\begin{array}{l}\text { Itonama/ } \\
\text { Mestiço }^{163}\end{array}$ \\
\hline $\begin{array}{l}\text { Eduardo Alberto } \\
\text { López }\end{array}$ & Podemos & $\begin{array}{l}\text { Advogado } \\
\text { constitucionalista }\end{array}$ & Tarija & Chapaco/ Mestiço \\
\hline $\begin{array}{l}\text { Carmen Eva } \\
\text { Gonzalez }\end{array}$ & Podemos & Pedagoga & Pando & NP/ Mestiça \\
\hline $\begin{array}{l}\text { Fernando Ávila } \\
\text { Chávez }\end{array}$ & Podemos & Médico & Beni & NP/ Mestiço \\
\hline
\end{tabular}

Fonte: Elaboração minha a partir de informações da Enciclopédia Histórica Documental del Proceso Constituyente Boliviano (Tomo iii, vol.1)

\footnotetext{
${ }^{162}$ Vaca Díez estava na linha sucessória para a presidência da Bolívia quando renunciou Carlos Mesa, em 2005. Para que Vaca Díez não assumisse o cargo, foram realizadas fortes mobilizações sociais (ver capítulo 2).

${ }^{163}$ Rubén Darío Cuellar, porta-voz do Podemos, é um dos constituintes que segundo Xavier Albó “fez um uso muito livre e até político" da autoidentificação como indígena, por ter se reconhecido como itonama, simplesmente por ter nascido no povoado de Magdalena (2008: 13).
} 
Dada a forma como foram eleitos os constituintes, as organizações indígenas contavam com apenas dois representantesna Comissão de Autonomias, Avilio Vaca, da Asamblea del Pueblo Guaraní (APG), e Evaristo Pairo Maraza, do Conamaq. Segundo Valencia e Égido, a APG, que mantinha alguma independência em relação ao Pacto de Unidade, havia conseguido a indicação deste representante guarani na lista do MAS, nas eleições de 2006, através de um acordo com o governo (2010: 87).Além da pequena representação indígena na comissão, podemos observar que a maioria dos constituintes eram profissionais liberais, e que apenas o representante guarani, Avilio Vaca, reconheceu-se "camponês" no critério de ocupação profissional.

Como presidente, vice-presidente e secretária geral desta comissão foram eleitos Saúl Ávalos, José Eduardo Yañez e Magda Lidia Calvimontes, respectivamente. O primeiro e a última pertencentes ao MAS e o vice-presidente ao MNR. Nenhum dos três se autoidentificava como indígena. Saúl Ávalos havia ganhado a cadeira de presidente contra a candidatura de Avilio Vaca.

A manutenção das regras do antigo jogo político na Lei de Convocatória da Assembleia Constituinte, e a consequente pequena participação de representantes das organizações indígenas na comissão, exigiam destas um trabalho de convencimento e de pressão sobre os constituintes, para que suas reivindicações fossem incluídas na nova Constituição.

A proximidade entre o MAS e o Pacto de Unidade não garantia que as propostas das organizações indígenas e camponesas recebessem o apoio de todos da bancada do partido em Sucre. Dessa forma, o fato do MAS e dos partidos aliados terem maioria na comissão de autonomias não garantia que as autonomias indígenas fossem incluídas no novo texto constitucional, já que vários representantes do partido não estavam de acordo com essa proposta do Pacto (Garcés, 2010b: 87). Fernando Garcés aponta uma forte 
fragmentação da bancada do MAS dentro dessa comissão, levando à elaboração, em determinado momento, de diferentes informes de maioria (alguns a partir da proposta do Pacto de Unidade e outros com a perspectiva individual de constituintes) (ibid.). Ao mesmo tempo, a proposta de autonomia indígena contava com o apoio de representantes de partidos não aliados ao MAS, como o MNR, que aceitou a proposta à condição de que as autonomias indígenas estivessem subordinadas às departamentais (ibid.: 83). Mas essa era, na verdade, uma condição inaceitável para as organizações que defendiam que as autonomias indígenas estivessem em um mesmo nível hierárquico das departamentais.

Outra demanda das organizações indígenas, relacionada ao seu projeto de autonomia, era a viabilização das reconstituições territoriais. Como representante da APG, Avilio Vaca defendia a bandeira de sua organização, para quem as autonomias eram um caminho para a reconstituição do território da nação guarani. Tal reconstituição era igualmente um projeto do Conamaq, que falava em "reconstituição territorial do Qullasuyu" ${ }^{\text {164 }}$, implicava no desconhecimento as fronteiras departamentais.

Durante as negociações na Comissão de Autonomias, indígenas guaranis realizaram uma importante mobilização, com o bloqueio de estradas no Chaco, a favor da inclusão da proposta de autonomias indígenas. Naquele momento, o presidente da comissão, Saúl Ávalos, foi acompanhado do representante guarani na Constituinte, Avilio Vaca, negociar com a APG.

A proposta das organizações indígenas só foi incluída no informe de maioria final elaborado pelos representantes do MAS, na véspera da sua entrega, sob pressão da VI Marcha, de julho de 2007, e a partir da ocupação pelo Conamaq da Casa Argandoña,

\footnotetext{
${ }^{164}$ Projeto apresentado pelo Conamaq. Enciclopedia Histórica Documental del Proceso Constituyente Boliviano, tomo ii, vol. 2, p. 1234.
} 
onde se reuniam os constituintes do partido (Garcés, 2010b: 87) ${ }^{165}$. A IV Marcha havia sido precedida por uma mobilização guarani que levou a um acordo com o presidente da Comissão de Autonomias, Saúl Ávalos, no qual este já havia prometido incluir a proposta de territórios indígenas autônomos no relatório da comissão (Valencia, Égido, 2010: 108). É interessante notar, contudo, que diferentes atores entrevistados e autores apontaram que a autonomia indígena teria sido adotada pelo MAS como contraponto à autonomia departamental, bandeira da oposição, sem ter em conta a forte pressão sofrida pela bancada do MAS para sua inclusão.

O informe de minoria da oposição na Comissão de Autonomias, embora reconheça o direito dos povos indígenas à sua autonomia, apontava a existência de apenas três níveis de governo com competências governamentais e legislativas: o nacional, o departamental e o municipal ${ }^{166}$. A ênfase era dada na manutenção das fronteiras administrativas republicanas. Nessa proposta, não era respeitada a igualdade hierárquica entre as diferentes autonomias. Assim, caberia aos governos departamentais “plenas faculdades para aperfeiçoar os institutos denominados Terras Comunitárias de Origem (TCOs) e municípios indígenas, assim como redesenhar seus limites dentro das atuais demarcações departamentais" (tradução minha) ${ }^{167}$. Ademais, a proposta das forças políticas de oposição limitava fortemente a demanda de autonomia indígena ao reconhecer, naqueles departamentos onde os indígenas fossem minoria, apenas a possibilidade de representação direta proporcional dos povos indígenas nas assembleias legislativas ou conselhos municipais. A criação de distritos, municípios, províncias ou

\footnotetext{
${ }^{165}$ Garcés aponta o impacto da aprovação da Declaração das Nações Unidas sobre os Direitos dos Povos Indígenas no momento final dos debates de temas como a autonomia indígena. "Este fato fortaleceu a proposta do Pacto já que os constituintes opositores e da bancada do MAS, que permanentemente olhavam com desconfiança, e inclusive rechaço, as demandas das organizações, viram-se obrigados a reconhecer o marco mais amplo no qual estava inserida a proposta do Pacto de Unidade (2010b: 87, tradução minha).

${ }^{166}$ Os informes de todas as comissões estão disponíveis na Enciclopedia Histórica Documental del Proceso Constituyente Boliviano, publicada pela vice-presidência do Estado Plurinacional.

${ }^{167}$ Lembro que diferentes TCOs, ao serem demarcadas respeitando os territórios tradicionalmente ocupados por povos indígenas, ultrapassam as fronteiras departamentais.
} 
departamentos indígenas aparece, no informe de minoria, apenas como uma possibilidade para os departamentos onde os povos indígenas sejam maioria demográfica.

$\mathrm{O}$ informe de maioria aborda a autonomia indígena de forma muito mais detalhada do que o outro informe, que foi dedicado principalmente à autonomia departamental. O informe de maioria retoma muitas propostas do Pacto de Unidade e indica a possibilidade de criação de autonomias indígenas a partir de territórios indígenas titulados coletivamente ou de municípios, e indica igualmente a possibilidade de criar-se uma região indígena a partir da união de diferentes territórios ou municípios. À diferença do outro informe, a proposta do MAS incluía entre as unidades territoriais que formam a Bolívia, além de departamentos, províncias e municípios, os territórios indígenas originários. Atendendo à demanda das organizações indígenas, o informe afirma que "não se admite nenhum tipo de tutela ou subordinação" entre os governos autônomos. $\mathrm{O}$ documento indica também que a conformação de entidades territoriais indígenas originárias autônomas está baseada na reconstituição de territórios ancestrais e na vontade da sua população e reconhece a possibilidade de criação, modificação e delimitação de unidades territoriais a partir da "vontade democrática de seus habitantes".

No que tange a inclusão do direito à autonomia dos povos indígenas na Constituição, esses dois informes seriam os documentos a partir dos quais foram negociados os acordos de outubro de 2007, coordenados pelo vice-presidente boliviano. Estes acordos suscitaram a crítica de constituintes indígenas, como Nélida Faldín e Avilio Vaca, que indicavam a restrição à autonomia indígena (Schavelzon, 2010: 2501). 
A autonomia indígena foi, dessa forma, uma demanda constantemente negociada com diferentes atores. Primeiro, assim como no caso de outras propostas, foi necessário um trabalho de diálogo entre as diferentes organizações sociais que formariam o Pacto de Unidade. Em seguida, caberia às organizações indígenas construir uma proposta comum com o MAS e, em certa medida, o governo nacional, sobre o tema do autogoverno indígena. Posteriormente, esta proposta foi negociada com a oposição, na tentativa de construção do "centro político" de nos fala Schavelzon (2010). Segundo o autor, esse centro que possibilitaria "aprovar a Constituição e avançar na fundação de um novo Estado, ainda que à custa de preservar as instituições do velho", era o objetivo do MAS nas negociações com a oposição (ibid.: 210).

Durante todo o período de funcionamento da Assembleia Constituinte houve uma constante negociação e redefinição da "autonomia indígena", processo que continuaria em 2008, com as modificações feitas na "Constituição de Oruro" nos diálogos de Cochabamba e no Congresso.

\subsection{A crise de 2008 e a nova da Constituição}

Em dezembro de 2007, a aprovação do estatuto autonômico de Santa Cruz, desconhecendo os marcos legais tanto da nova constituição, como da antiga, indicava que a crise política não havia chegado ao fim com a votação em Oruro. Em realidade, 2008 marcaria o recrudescimento da crise, colocando em risco a continuidade do "processo de mudança" liderado por Evo Morales.

Em 2008, foram ocupadas mais de 75 instituições estatais em cinco departamentos, houve dois cercos ao poder legislativo, foram realizados referendos ilegais sobre estatutos autonômicos departamentais, ocorreu o episódio conhecido como 
"massacre de Pando" e a constituição foi reescrita em grupos de trabalhos (Miranda, 2012). A seguir, destacarei alguns dos muitos eventos ocorridos em 2008, que evidenciam a grande polarização política na Bolívia naquele momento, e o cenário político no qual a constituição foi reescrita. Seus efeitos para a consolidação do direito à autonomia indígena serão importantes.

Nos primeiros meses de 2008, fracassaram as diferentes tentativas de diálogo entre o governo e a oposição, para a convocação do referendo que deveria consultar a população sobre a aprovação da nova Constituição Política. O Podemos liderava a oposição ao governo no Senado enquanto os governadores dos departamentos da Meia Lua orquestravam o enfraquecimento do governo por meio da realização de referendos autonômicos departamentais. Miranda sublinha, contudo, a existência de uma divisão dentro dos próprios grupos opositores: "no Podemos não tinham dúvida que a partir das regiões buscava-se eliminá-los como referente opositor" (ibid.: 117, tradução minha).

Os governadores da Meia Lua condicionavam a negociação com o governo sobre o texto constitucional e os estatutos departamentais aprovados ilegalmente à reversão da medida que havia descolado parte dos ingressos departamentais correspondentes ao Imposto Direto sobre os Hidrocarbonetos (IDH) para o pagamento da renta dignidad à população acima de 60 anos (Peñareda, 2009: 139).

Naquele momento, a oposição departamental ao governo de Evo Morales estava organizada no Consejo Nacional Democratico (Conalde). No entanto, a disputa política ultrapassava as fronteiras do campo da política institucional e, assim como durante o período de realização da Assembleia Constituinte, tomava as ruas e estradas do país. Em Santa Cruz e Tarija, prédios de organizações não governamentais, organizações indígenas e órgãos públicos foram alvo de ataques. Segundo Carlos Böhrt, então senador pelo Podemos, esses eventos de "beligerância política" e o fracasso dos 
esforços de concertação apontavam a possibilidade do país entrar em guerra civil. “Tudo parecia sugerir que algo grave poderia passar a qualquer momento" (2009: 56, tradução minha).

O plebiscito sobre o estatuto autonômico de Santa Cruz foi convocado para o dia 4 de maio de 2008. De um lado, em áreas rurais, migrantes das Terras Altas bloqueavam as estradas e, no Plano 3000, bairro de Santa Cruz onde vive uma grande população de baixa renda, esta se organizou contra o plebiscito ilegal. De outro lado, o Comitê Cívico departamental mobilizou a Unión Juvenil Cruceñista (UJC), à qual se juntaram dezenas de milhares de pessoas, para garantir a realização do plebiscito (Miranda, 2012: 108-9). O resultado foi uma batalha na qual os dois grupos se enfrentaram no Plano 3000, "em meio a armas de fogo, gases lacrimogênio, petardos e pedradas" (ibid.: 110, tradução minha).

Naquele mesmo mês, as ruas da cidade de Sucre seriam palco de novos enfrentamentos. Estava previsto para o dia 24 maio um ato de entrega de ambulâncias a comunidades camponesas no qual participaria o presidente Morales e camponeses da região foram a Sucre para participar do evento. Poucos meses passados desde a batalha que tomou conta da cidade durante a aprovação do texto constituinte, a oposição mobilizou-se para impedir o evento, que foi finalmente cancelado (ibid.). No entanto, houve enfrentamento com os militares e alguns camponeses foram detidos por militantes da oposição - nesse caso, formada em sua maioria por aqueles estudantes universitários que haviam se mobilizado no ano anterior pela "capital plena" - e levados para a praça principal da cidade. Ali foram obrigados a despir-se parcialmente, queimar 
suas bandeiras e ficarem ajoelhados enquanto a multidão gritava "Sucre de pé! Evo de joelhos!"168.

Episódios de racismo e violência contra indígenas camponeses e contra as sedes de suas organizações e de organizações não governamentais que os apoiavam foram recorrentes durante o ano de 2008. Ao mesmo tempo, o presidente Evo Morales, seus ministros e demais representantes do governo central eram impedidos não só de participar de eventos públicos, como também de atividades mais restritas nos departamentos da Meia Lua.

Em junho, outros departamentos da Meia Lua, Pando, Beni e Tarija, seguiram o exemplo de Santa Cruz e realizaram igualmente referendos para a aprovação de estatutos autonômicos. Em todas as consultas, o "sim" ganhou com uma maioria esmagadora de votos: $79,5 \%$ no Beni; $81,96 \%$ no Pando; $85,6 \%$ em Santa Cruz; e, 78,8\% em Tarija (Miranda, 2012: 113). Segundo dados da Vice-Presidência da Bolívia, os $85,6 \%$ daqueles que aprovaram o estatuto de Santa Cruz correspondiam a 477.872 votos, 11 mil a menos do que aqueles recebidos no referendo realizado em 2006 , onde o sim havia alcançado $71 \%$ dos votos totais (Unidad de Información para la Participación Ciudadana, Dirección de Participación Ciudadana, 2010: 9). Sem dúvida, esses resultados foram influenciados pela abstenção de parte importante daqueles que se opunham a realização do referendo, contudo, eles indicam igualmente a adoção por grande parte da população do Oriente da bandeira autonômica das elites regionais.

Em dezembro de 2007, Morales havia enviado ao Congresso a Lei de Convocatória a um referendo revocatório. Essa foi a solução encontrada pelo governo para o impasse no qual se encontravam as negociações políticas depois da Assembleia

${ }^{168}$ Esses atos de violência foram transmitidos por canais de televisão. Neste vídeo é possível ver algumas dessas imagens: http://www.youtube.com/watch?v=Y6Da5bO890I, acessado em 14/04/2014. É impossível não pensar na relação entre o "grito de guerra" entoado em Sucre e aquele que os moradores de El Alto adotaram durante a guerra do gás: "El Alto de pé! Nunca de joelhos!" 
Constituinte. Por meio do referendo, a população seria chamada a decidir sobre a continuidade do mandato de Evo Morales e García Linera, e das autoridades executivas dos nove departamentos bolivianos. A proposta foi finalmente aceita pelo Podemos, em maio de 2008, depois da realização da consulta sobre a autonomia departamental em Santa Cruz.

A despeito das diferenças com os constituintes do MAS durante a realização da Assembleia Constituinte, no dia 18 de julho, as autoridades do Conamaq lançaram o "Mandato de Achocalla III, ao Conselho de governo do Conamaq, aos Conselhos de seus Suyus, às Markas e aos Ayllus" no qual eram emitidos, dentre outros, os seguintes mandatos: "promover uma aliança estratégica, com independência política, com o hermano Evo Morales A., para consolidar o exercício do governo originário" e “enfrentar a direita oligárquica” .

No dia 10 de agosto de 2008, 67\% dos bolivianos votaram a favor da continuidade do governo de Evo Morales, apesar da campanha pelo "não" organizada pela oposição. Em 95 das 112 províncias do país o governo saiu vencedor. Esse resultado representava não apenas um aumento considerável em relação aos votos obtidos em 2005, como indicava que mesmo nos departamentos da chamada Meia Lua, havia um forte apoio ao governo central. Em Santa Cruz, Beni e Tarija venceu o "não", com 59,25\%; 56,8\% e 50,17\%, respectivamente. Em Pando e Chuquisaca, onde está localizada a cidade de Sucre, o governo ganhou com, 52,5\% e 53,88\%. Já nos departamentos de La Paz, Cochabamba, Oruro e Potosí, a continuidade do governo foi aprovada por uma maioria impressionante: 83,27\%; 70,9\%; 83\%; 84,87\%, respectivamente. Nos departamentos, os mandatos dos governadores foram confirmados em Santa Cruz (66,45\%), Tarija (58,06\%), Pando (56,21\%), Potosí $(79,08)$, Oruro (50,86\%) e Beni $(64,27 \%)$ e revogados em La Paz, com 64,21\% a favor do "não" e 
Cochabamba, com $64,81 \%{ }^{169}$. Em Chuquicasa, onde fica localizada a cidade de Sucre, a governadora havia sido eleita recentemente e não houve consulta sobre a possível revogação de seu mandato ${ }^{170}$.

Sem dúvida, o grande vencedor do referendo foi o governo de Evo Morales, que, além de confirmar nas urnas a legitimidade de seu mandato, pode nomear temporariamente quem ocuparia o Executivo em La Paz e Cochabamba, que até então estavam em mãos da oposição.

No dia 11 de agosto, um dia depois da realização do referendo, o governo convidou os governadores a retomarem o diálogo em La Paz. Rubén Costas, então governador de Santa Cruz, foi o único a recusar o convite (Peñareda, 2009: 149). Embora o diálogo não tenha resultado no acordo esperado, ele parecia indicar que a vitória de Evo Morales no referendo havia mudado o cenário político dentro do qual a oposição podia agir. Não obstante essa aparente distensão, os governadores opositores declararam, no dia 19 de agosto, uma paralização por tempo indefinido. Mais uma vez, o tema do repasse do Imposto Direto sobre os Hidrocarbonetos (IDH) foi mobilizado pela oposição. Contudo, apenas os centros urbanos responderam à convocatória de paralização e a medida de pressão foi considerada um fracasso (ibid.: 153).

Progressivamente, o governo pôs em marcha uma estratégia de aproximação com o Podemos, por meio dos senadores Carlos Börth e Roberto Ruíz, e com os governadores da Meia Lua, através do governador de Tarija, Mario Cossío (Peñareda, 2009). Houve igualmente uma tentativa de convocar o refendo sobre a Constituição,

\footnotetext{
${ }^{169}$ Fonte: Vicepresidencia de la República - Unidad de Información para la Participación Ciudadana. "Resultados electorales, Referéndum Revocatorio 2008".

Para revogar o mandato, era necessário que o percentual de voto pelo "não" fosse igual ou superior àquele recebido pelos governadores ou pelo presidente, quando eles foram eleitos em 2005.

${ }^{170}$ Em dezembro de 2007, o governador David Sanchéz, do MAS, havia renunciado em função da crise política vivida no departamento desde a Assembleia Constituinte. Para substituir Sanchéz, foi eleita Savina Cuéllar, antiga militante do MAS que havia passado para oposição.
} 
eleições para os departamentos de La Paz e Cochabamba e para subprefectos (autoridades provinciais) e consejeros departamentais por meio de um Decreto Supremo. Essa tentativa fracassou, pois, a Corte Nacional Eleitoral se recusou a organizar tal consulta por considerá-la ilegal (ibid.: 150).

Paralelamente, parte da oposição manteve sua estratégia de perpetuar a crise política. Bloqueios de estradas em Santa Cruz, Tarija e Potosí foram organizados. No dia 30 de agosto, manifestantes que apoiavam o Decreto da Presidência foram violentamente atacados no centro da cidade de Santa Cruz ${ }^{171}$.

Até princípios de setembro, haviam sido ocupadas sete entidades estatais e 140 postos de controle e pedágio na Meia Lua (Miranda, 2012: 134). Dentre os prédios do governo central invadidos em Santa Cruz, estava a sede do Instituto Nacional de Reforma Agrária (Inra), que se encontrava sob a proteção da Polícia Militar. Os representantes da Unión Juvevil Cruceñista (UJC) queimaram todos os arquivos encontrados. Contudo, pouco se perdeu já que, semanas antes, a sede nacional do Inra havia começado a transferir todos os documentos da regional para La Paz (ibid. 137-8). Tiveram uma sorte diferente os documentos do Inra de Tarija, destruídos quando a sede do instituto foi invadida (ibid.: 139). No dia 2 de setembro, as sedes do Inra em Trinidad, no departamento do Beni, e em Pando foram igualmente alvo de ataques de grupos opositores, bem como outros escritórios do governo central (Peñareda, 2009: 154).

No dia 9 de setembro, a sede em Santa Cruz do Cejis, importante ONG que trabalha com organizações indígenas e camponesas, foi invadida e incendiada. No dia

\footnotetext{
${ }^{171}$ La Jornada, 31/08/2008. Disponível em: http://www.jornada.unam.mx/2008/08/31/index.php?section=mundo\&article=030n1mun.
} 
seguinte, a sede da organização indígena CPESC foi totalmente destruída ${ }^{172}$. A companhia de telecomunicação Entel, recém nacionalizada pelo governo, foi igualmente alvo da UJC. Em Tarija, universitários se enfrentaram com camponeses no mercado local e, em Santa Cruz, explodiram parte do gasoduto que levava gás para o Brasil (Peñareda, 2009: 157).

No dia 10 de setembro, o governo denunciou que um golpe de estado "atípico" estava sendo planejado por "grupos paramilitares fascistas y terroristas" dos governos e comitês cívicos da Meia Lua e anunciou a expulsão do embaixador estadunidense, acusado de financiar os grupos opositores através da Agência Estadunidense para o Desenvolvimento Internacional (Usaid) ${ }^{173}$.

Em 2008, diferente do que ocorrera anos antes, o enfrentamento não se dava entre o governo, e suas forças repressivas, e a população civil; agora, a disputa do campo da política institucional se refletia nos embates nas ruas entre os que defendiam o proceso de cambio e aqueles que se opunham às mudanças. Dessa forma, ao mesmo tempo em que os escritórios governamentais e de organizações que apoiavam o governo eram atacados, os camponeses organizaram bloqueios de estradas para isolar o departamento de Santa Cruz.

O então secretário geral da Confederación Sindical de Colonizadores de Bolivia (CSCB), Fidel Surco, convocava a população a que ocupassem as praças de todas as províncias e os municípios "para defender a democracia e a unidade do país" "174. Fidel Surco era então o presidente da Coordinadora Nacional por el Cambio (Conalcam). A Conalcam havia sido criada em janeiro de 2007, em uma reunião de 16 movimentos

\footnotetext{
${ }^{172}$ Fonte: http://cejis.org/casos-en-bolivia/, consultado em 15/04/2014.

${ }^{173}$ La Jornada, 11/09/2008. Disponível em: http://www.jornada.unam.mx/2008/09/11/index.php?section=mundo\&article=036n1mun. ${ }^{174}$ Folha de São Paulo, 10/09/2008. Disponível em: http://www1.folha.uol.com.br/folha/mundo/ult94u443622.shtml.
} 
sociais com o presidente Evo Morales, o vice-presidente Álvaro García Linera, membros do Poder Executivo, Legislativo e da Assembleia Constituinte. Tratava-se de “uma espécie de „estado maior político cujo objetivo é apoiar o programa de reformas do governo Evo Morales" ${ }^{\prime 175}$.

Ao mesmo tempo em que as organizações dos setores subalternos superavam momentaneamente suas divergências para defender o "processo de mudança", as rupturas dentro do bloco opositor se tornavam cada vez importantes. Primeiro houve o afastamento entre os governadores opositores e o Podemos, agora, em Santa Cruz, o governador estava rompendo com seu grande aliado, o Comitê Cívico Pró-Santa Cruz, principal responsável por articular a violência nas ruas (Miranda, 2012: 141).

No dia 11 de setembro, um evento foi central na desarticulação da estratégia de desestabilização política adotada pela oposição: o "massacre de Pando". Tratou-se de uma embosca contra camponeses e indígenas, que se dirigiam a um evento político contra o governador do departamento do Pando, o opositor Leopoldo Fernandez. Estima-se que duas dezenas de manifestantes foram assassinados neste episódio. Leopoldo Fernandez foi acusado de ter envolvimento no evento, quando foram identificados funcionários da prefeitura e veículos oficiais nos vídeos feitos no momento do ataque. $\mathrm{O}$ embate entre o governo central e o governo de Pando levou o primeiro a declarar Estado de Sítio naquele departamento.

Naquele momento, em Santa Cruz, enfrentavam-se moradores do Plan 3000 e membros da UJC, que tentavam furar os bloqueios organizados para proteger essa região da cidade.

\footnotetext{
175 Fonte: http://constituyentesoberana.org/3/propuestas/gobierno/enero2007/230107 1.html, consultado em $15 / 04 / 2014$.
} 
O massacre em Pando teve importante repercussão dentro e fora do país, desencadeando uma postura mais ativa por parte dos governos da região em solucionar a crise política vivida pela Bolívia. A União das Nações Sul-americanas (Unasul) desempenhou a partir de então um importante papel de intermediação entre o governo e representantes da oposição.

No dia seguinte ao massacre, o governador de Tarija, Mario Cossío, e outros representantes do departamento, reuniram-se com membros do governo e o senador de Tarija pelo Podemos, Roberto Ruíz, no Palácio do governo em La Paz, que se encontrava cercado por movimentos sociais aliados a Evo Morales (Peñareda, 2009). Dois dias depois do massacre em Porvenir, o governador de Santa Cruz, Rubén Costas, foi a La Paz negociar a entrega das instituições do governo central que haviam sido tomadas no departamento (Miranda, 2012: 143).

Após o massacre de Pando, todos os governadores opositores aceitaram o acordo que o governador de Tarija estava negociando com o governo central (Peñareda, 2009).

Diferente do que ocorrera em 2003, quando os setores subalternos se levantaram para derrubar o presidente Sánchez de Lozada, a estratégia de mobilização da oposição ao governo não foi suficientemente eficaz para interromper o mandato de Evo Morales. Este não apenas contava com uma legitimidade, confirmada no referendo, muito maior que a do governo de Goni, como também mantinha a capacidade de mobilização de suas bases. Agora, os bloqueios de estradas eram organizados não apenas para destituir o presidente, mas também para apoiá-lo.

A Central Obrera Boliviana (COB), que em maio havia organizado uma greve contra a proposta de sistema de pensões elaborada pelo governo, assinou um "pacto de 
unidade" com a Conalcam, no dia 17 de setembro, reforçando a base de apoio oficial de Morales $^{176}$.

Como resultado do diálogo iniciado nos dias anteriores com os governadores oposicionistas, no dia 19 de setembro, duas mesas de negociação com a oposição foram organizadas em Cochabamba. A partir desse momento, a Constituição de Oruro seria modificada. Uma mesa tratava da distribuição do Imposto Direto sobre Hidrocarbonetos (IDH) e a outra das autonomias. A segunda mesa foi coordenada por Carlos Romero, que havia sido membro da Assembleia Constituinte. Representantes das igrejas católica, metodista e evangélicas participavam como observadores dos diálogos de Cochabamba, ao lado de representantes de diferentes países, como os embaixadores do Brasil, Colômbia, Grã-Bretanha, representantes da Organização dos Estados Americanos (OEA) e da Comissão Europeia (Peñareda, 2009: 179-80).

Foram 17 dias de negociação, nos quais foi decidido que o governo devolveria aos departamentos um percentual do IDH usado para pagar a renta dignidad. Como aponta Peñareda, o governo fez concessões importantes na mesa de autonomias, mas, ainda assim, os prefeitos opositores se negaram a assinar o acordo, estendendo por mais algum tempo a indefinição sobre o texto constitucional final (2009: 180).

$\mathrm{Na}$ mesa de autonomias participaram igualmente assessores da Cidob e do Conamaq, sob a insistência destas organizações, que perceberam nas mesas de diálogo entre representantes da oposição e do governo uma possível ameaça ao direito à autonomia indígena, reconhecido na Constituição de Oruro.

No dia 24 de setembro, o Conamaq e a Cidob haviam lançado uma convocatória a um encontro nacional "para a construção da viabilidade de suas demandas

\footnotetext{
${ }^{176}$ Página 12, 18/10/2008. Disponível em: http://www.pagina12.com.ar/diario/ultimas/subnotas/11174935336-2008-09-17.html.
} 
autonômicas". O objetivo do encontro seria "gerar um espaço de discussão política e de construção coletiva entre o Conamaq e a Cidob, que permita ter um documento comum de negociação sobre as autonomias indígenas, a ser apresentado e negociado com o governo e a Conalcam em seu próximo ampliado nacional"177.

O ampliado da Conalcam foi convocado para o dia 27 de setembro, em Cochabamba. No documento redigido no evento, as organizações sociais confirmavam a defesa da "democracia, democrática e cultural, sob a liderança do presidente Evo Morales Ayma"; denunciavam a tentativa de "golpe de estado cívico prefectural"; e convocavam a mobilização para "garantir a aprovação da nova Constituição Política do Estado, para garantir a refundação política, econômica, social e cultural da Bolívia, com unidade, justiça social, igualdade, equidade e solidariedade". Ademais, uma marcha foi convocada, para o dia 13 de outubro, para pressionar o Congresso a aprovar a lei de convocatória do referendo constituinte. As principais organizações sociais dos setores subalternos bolivianos assinaram o documento ${ }^{178}$.

Em uma resolução aprovada no mesmo dia do encontro da Conalcam, o Conamaq afirmava a disponibilidade em convocar as suas bases para cobrar a punição para os autores do massacre de Pando; denunciava a "atitude dilatória dos governadores da Meia Lua no diálogo nacional, que não permite que a concertação prospere”; e, confirmava a resolução da Conalcam sobre a organização de uma mobilização e possível cerco ao Congresso boliviano para que este aprovasse a lei de convocatória do

\footnotetext{
${ }^{177}$ Conamaq, Cidob. Convocatoria para Encuentro Nacional de Conamaq y Cidob para la construcción de la viabilidad de sus demandas autonómicas. 24 de setembro de 2008.

${ }^{178}$ As organizações signatárias foram as seguintes: Confederación Sindical Única de Trabajadores Campesinos de Bolivia (CSUTCB); Consejo Nacional de Markas y Ayllus del Qullasuyu (Conamaq); Confederación de los Indígenas del Oriente Boliviano (Cidob); Confederación Sindical de Colonizadores de Bolivia (CSCB); Confederación de Mujeres Campesinas de Bolivia Bartolina Sisa (CNMCB-BS); Confederación Nacional de Rentistas Jubilados de Bolivia (CNRJB); Federación Nacional de Cooperativas Mineras de Bolivia (Fencomin); Confederación Nacional de Gremiales de Bolivia (CNGB); Central Obrera Regional (COR) de El Alto; Confederación Nacional de Panificadores de Bolivia (CNPB); Movimiento Sin Tierra (MST); Confederación del Transporte Libre del Campo y la Ciudad (CTLCC).
} 
referendo constituinte, afirmando: "Nós respondemos orgânica e contundentemente para que de uma vez por todas cheguem os tempos de Pachakuti a este grande Quollana Suyu, cujos filhos se encontram de pé, na luta para ser parte da construção da história destes tempos de mudança". As autoridades do Conamaq exigiam igualmente a participação no diálogo com a oposição e que os constituintes fossem consultados sobre as mudanças no texto ${ }^{179}$.

Também do dia 27 de setembro de 2008, as capitanias guaranis de Parapitiguasu e Charagua Norte publicaram um pronunciamento no qual denunciavam o "racismo extremo gerado por grupos violentos contra cidadãos indígenas camponeses na cidade de Santa Cruz" e o massacre em Pando. E afirmavam: "a luta pela autonomia e a autodeterminação dos povos indígenas com igualdade de hierarquia de competências é irrenunciável, não se negocia" ${ }^{180}$.

Depois dos diálogos de Cochabamba, no dia 8 de outubro, iniciou-se a negociação no Congresso. Enquanto os primeiros haviam sido focados no tema das autonomias, as negociações seguintes tratavam dos demais pontos de divergência com a oposição parlamentar.

O Congresso realizaria 144 modificações em 122 artigos da Constituição de Oruro (Garcés, 2013: 35). As principais exigências da oposição eram as seguintes: incorporar ao texto constitucional as expressões nação e nacionalidade boliviana e a alusão à "república"; que se esclarecesse em que consistia a livre determinação dos povos indígenas; que a reforma constitucional fosse aprovada por uma maioria de dois terços dos membros do Parlamento; que os membros da Corte Nacional Eleitoral fossem eleitos com a mesma maioria; que se garantisse a grandes cooperativas [que

${ }^{179}$ Conamaq. Resolución de Conamaq y sus suyus por la defensa de nuestro derecho al autogobierno y la autodeterminación. 27 de setembro de 2008.

${ }_{180}$ Pronunciamento de las Capinatinas de Charagua Norte e Parapitiguasu de la APG. 27 de setembro de 2008. 
pertenciam a grandes grupos empresariais] a possibilidade de prestar serviços públicos; e, finalmente, que fosse respeitada a extensão de terra dos latifúndios (Peñareda, 2009: 184).

No dia 13 de outubro, a Conalcam organizou a anunciada marcha com o intuito de pressionar por um acordo entre partidos de oposição e o governo para a convocação do referendo constituinte. A marcha começou com cerca de sete mil pessoase foi encabeçada por Evo Morales. Ao longo dos 200 quilômetrospercorridos entre Oruro e La Paz, a mobilização cresceu e, quando ela chegou à Praça Murillo, sede dos poderes Executivo e Legislativo, no dia 20 de outubro, havia cerca de cem mil manifestantes (Peñaranda, 2009: 185).

Depois de negociações em mesas oficiais e extraoficiais com os partidos de oposição, o Congresso, cercado pelos manifestantes, aprovou finalmente o acordo para a convocação do referendo constituinte, no dia 21 de outubro, com 106 votos a favor. Dada a divisão no interior do Podemos, o acordo foi aprovado com a estreita margem de um voto a mais do que os dois terços necessários (ibid.: 197).

Sobre o acordo de 21 de outubro com o Parlamento, Carlos Romero, constituinte e ator fundamental nas negociações com a oposição em 2008, afirma:

O pacto político nacional permitiu melhorar qualitativamente os conteúdos do texto constitucional, pacificar o país em um momento quem que se encontravaà beira da confrontação civil e compatibilizar, no que era fundamental, as duas visões de país contrapostas (Romero Bonifaz, 2009: 43, tradução minha).

Para Jorge Lazarte (2009), membro do partido de oposição Unidad Nacional (UN) e vice-presidente da Assembleia Constituinte, esses acordos corrigiram incongruências do texto aprovado em Oruro, sem mudar a sua essência. Contudo, 
Lazarte afirma que "a Assembleia Constituinte depois de ter sido exaltada, terminou humilhada" (ibid.: 20, traduçãominha), pois os membros das constituintes não teriam participado da edição da constituição realizada em 2008.

Logo, se 2008 foi marcado por uma forte crise política, parece também ter sido o ano da superação da crise que havia iniciado no ano de 2000 , e que havia perdurado após a posse de Evo Morales, ainda que com características distintas. O resultado foi um texto constitucional modificado por atores diferentes daqueles que a população havia eleito para redigi-lo, e sem o protagonismo das organizações sociais que haviam marchado pela Constituinte e que nela haviam participado de forma ativa. As fronteiras do campo da política institucional pareciam estar se fechando novamente.

Para o direito à autonomia dos povos e nações indígena originário camponeses, importantes limites foram impostos a partir dos novos acordos, como apresento a seguir:

\begin{tabular}{|l|l|l|}
\hline Artigo (Constituição atual) & Constituição de Oruro & $\begin{array}{l}\text { Constituição modificada pelo } \\
\text { Congresso }\end{array}$ \\
\hline $\begin{array}{l}\text { Sobre Direitos dos Povos e } \\
\text { Cações Indígena Originário }\end{array}$ & $\begin{array}{l}\text { Á gestão territorial indígena } \\
\text { autônoma e ao uso do } \\
\text { aproveitamento exclusivo dos } \\
\text { recursos naturais renováveis } \\
\text { existentes em seu território. }\end{array}$ & $\begin{array}{l}\text { Á gestão territorial indígena } \\
\text { autônoma e ao uso do } \\
\text { aproveitamento exclusivo dos } \\
\text { recursos naturais renováveis } \\
\text { existentes em seu território } \\
\text { sem prejuízo dos direitos } \\
\text { legitimamente adquiridos } \\
\text { por terceiros. }\end{array}$ \\
\hline $\begin{array}{l}\text { Sobre Jurisdição Indígena } \\
\text { Originário Camponesa (IOC): } \\
\text { Art. 191 }\end{array}$ & $\begin{array}{l}\text { A jurisdição IOC conhecerá } \\
\text { todo tipo de relações } \\
\text { jurídicas, assim como atos e } \\
\text { feitos, que vulnerem bens } \\
\text { jurídicos realizados dentro do } \\
\text { âmbito territorial IOC. }\end{array}$ & $\begin{array}{l}\text { A jurisdição IOC se } \\
\text { fundamenta em um vínculo } \\
\text { particular de pessoas que } \\
\text { são membros da respectiva } \\
\text { nação ou povo IOC. }\end{array}$ \\
\hline
\end{tabular}




\begin{tabular}{|c|c|c|}
\hline $\begin{array}{l}\text { Sobre autonomia indígena } \\
\text { originário camponesa: Art. } \\
289\end{array}$ & $\begin{array}{l}\text { A autonomia IOC é a } \\
\text { expressão do direito ao } \\
\text { autogoverno como exercício } \\
\text { de autodeterminação das } \\
\text { nações e povos indígenas } \\
\text { originário, e das comunidades } \\
\text { camponesas, cuja população } \\
\text { comparte território, cultura, } \\
\text { história, línguas e } \\
\text { organização ou instituições } \\
\text { jurídicas, políticas, sociais e } \\
\text { econômicas próprias. }\end{array}$ & $\begin{array}{l}\text { A autonomia IOC consiste no } \\
\text { autogoverno como exercício } \\
\text { da livre determinação das } \\
\text { nações e povos IOC, cuja } \\
\text { população comparte } \\
\text { território, cultura, história, } \\
\text { línguas e organização ou } \\
\text { instituições jurídicas, } \\
\text { políticas, sociais e } \\
\text { econômicas próprias. }\end{array}$ \\
\hline $\begin{array}{l}\text { Sobre a autonomia indígena } \\
\text { originário camponesa Art. } \\
290\end{array}$ & $\begin{array}{l}\text { A conformação de entidades } \\
\text { territoriais IOC autônomas } \\
\text { está baseada nos territórios } \\
\text { ancestrais e na vontade de sua } \\
\text { população, expressa em } \\
\text { consulta, conforme suas } \\
\text { normas e procedimentos } \\
\text { próprios e de acordo com a } \\
\text { lei. }\end{array}$ & $\begin{array}{l}\text { A conformação da autonomia } \\
\text { IOC está baseada nos } \\
\text { territórios ancestrais } \\
\text { atualmente habitados por } \\
\text { esses povos e nações e na } \\
\text { vontade de sua população } \\
\text { expressa em consulta. }\end{array}$ \\
\hline Art. 293 & $\begin{array}{l}\text { Para conformar um território } \\
\text { IOC autônomo que } \\
\text { compreenda mais de uma } \\
\text { entidade territorial IOC } \\
\text { autonomia, a lei apontará os } \\
\text { mecanismos de articulação, } \\
\text { coordenação e cooperação } \\
\text { entre as unidades e a entidade } \\
\text { para o exercício de seu } \\
\text { governo. }\end{array}$ & $\begin{array}{l}\text { I. A autonomia indígena } \\
\text { baseada em territórios } \\
\text { consolidados e naqueles em } \\
\text { processo, uma vez } \\
\text { consolidados, constituir-se-á } \\
\text { pela vontade de sua } \\
\text { população expressa em } \\
\text { consulta em conformidade } \\
\text { com suas normas e } \\
\text { procedimentos próprios como } \\
\text { único requisito exigido. } \\
\text { II. Se a conformação de uma } \\
\text { autonomia IOC afetar limites } \\
\text { de distritos municipais, o }\end{array}$ \\
\hline
\end{tabular}




\begin{tabular}{|c|c|c|}
\hline & & $\begin{array}{l}\text { povo ou nação IOC e o } \\
\text { governo municipal deverão } \\
\text { acordar uma nova delimitação } \\
\text { distrital. Se afetar limites } \\
\text { municipais, deverá seguir um } \\
\text { procedimento frente à } \\
\text { Assembleia Legislativa } \\
\text { Plurinacional para sua } \\
\text { aprovação, prévio o } \\
\text { cumprimento de requisitos e } \\
\text { condições assinalados na lei. } \\
\text { III. A lei estabelecerá os } \\
\text { requisitos mínimos de } \\
\text { população e outros } \\
\text { diferenciados para a } \\
\text { construção da autonomia } \\
\text { IOC. } \\
\text { IV. Para constituir uma } \\
\text { autonomia IOC cujos } \\
\text { territórios se encontrem em } \\
\text { um ou mais municípios, a lei } \\
\text { assinalará os mecanismos de } \\
\text { articulação, coordenação e } \\
\text { cooperação para o exercício } \\
\text { de seu governo. }\end{array}$ \\
\hline Art. 294 & $\begin{array}{l}\text { I. A decisão de converter um } \\
\text { ou mais municípios existentes } \\
\text { em um município IOC ou em } \\
\text { território IOC se adotará de } \\
\text { acordo com as duas normas e } \\
\text { procedimentos de consulta } \\
\underline{\text { direta própria, conforme os }} \\
\text { requisitos e condições } \\
\text { estabelecidos pela }\end{array}$ & $\begin{array}{l}\text { I. A decisão de construir uma } \\
\text { autonomia IOC se adotará de } \\
\text { acordo a suas normas e } \\
\text { procedimentos de consulta, } \\
\text { conforme requisitos e } \\
\text { condições estabelecidos na } \\
\text { Constituição na lei. } \\
\text { II. A decisão de converter } \\
\text { um município em }\end{array}$ \\
\hline
\end{tabular}




\begin{tabular}{|l|l|l|}
\hline Constituição e pela lei. & $\begin{array}{l}\text { autonomia IOC se adotará } \\
\text { mediante referendo } \\
\text { II. A decisão de converter } \\
\text { municípios e territórios IOC } \\
\text { em uma região territorial IOC } \\
\text { se adotará por agregação } \\
\text { destes, de acordo com suas } \\
\text { normas e procedimentos de } \\
\text { consulta direta própria, } \\
\text { conforiabelecidos por } \\
\text { lei. } \\
\text { condições estabelecidos pela } \\
\text { Constituição e pela lei. } \\
\text { III. Nos municípios onde } \\
\text { existam comunidades } \\
\text { camponesas com estruturas } \\
\text { (art. 296). Nos espaços } \\
\text { geográficos onde existam } \\
\text { comunidades camponeses } \\
\text { articulem e com continuidade } \\
\text { interculturais e estruturas } \\
\text { organizativas que as } \\
\text { articulem, poderão formar } \\
\text { municípios camponeses } \\
\text { autônomos, conforme a } \\
\text { Constituição e a lei. }\end{array}$ & $\begin{array}{l}\text { um novo município, seguindo } \\
\text { o procedimento frente à } \\
\text { Assembleia Legislativa } \\
\text { Plurinacional para sua } \\
\text { aprovação, prévio } \\
\text { cumprimento de requisitos e } \\
\text { condições, conforme a } \\
\text { Constituição e a lei. }\end{array}$ \\
\hline
\end{tabular}

Dentre as mudanças no texto constitucional que afetam diretamente o direito à autonomia e à administração de territórios indígenas destacam-se: a impossibilidade de construção de autonomias em territórios ancestrais não encontram-se atualmente habitados por povos indígenas, ainda que estes tenham sido expulsos por diferentes razões externas, como a pressão sobre a terra para a construção de haciendas ou outro tipo de ocupação por terceiros; a exclusão das comunidades camponesas de "colonizadores", ou "interculturais", ou seja, migrantes em conformarem uma autonomia; a imposição de limites populacionais mínimos; e, também, a limitação da jurisdição indígena, que está diretamente relacionada à autonomia indígena. 
A disputa em torno das autonomias indígenas e sua definição não terminará com o acordo no Congresso. Dado o caráter aberto da nova Constituição boliviana, apontado por Schavelzon (2012), serão importantes os debates em torno da elaboração da Lei Marco de Autonomias e Descentralização, responsável por “completar" os "espaços abertos" no que tange a autonomia indígena. Essas disputas, que apresentarei nos próximo capítulo, refletir-se-iam igualmente durante o processo de conversão de municípios e territórios em autonomias indígena originário camponesas. Contudo, elas ocorreriam em um cenário político mais estável, resultado da superação da crise política vivida até então. 


\section{Capítulo 4: Depois da crise: a autonomia indígena no Estado Plurinacional}

"Una vez MAS porque así manda el pueblo"

Grafite em um muro da cidade de Sucre, janeiro de 2010.

No dia 25 de janeiro de 2009, 61,43\% dos bolivianos votaram pela aprovação da nova Constituição. O "sim” havia ganhado em Potosí, Oruro, Cochabamba, La Paz e Chuquisaca e o "não", nos demais departamentos ${ }^{181}$. Naquele dia, Evo Morales declarava: "Aqui acabou o colonialismo interno e externo, acabou o Estado colonial, aqui acabou o neoliberalismo" ${ }^{\text {"182 }}$.

Em dezembro daquele ano, Evo Morales e Álvaro García Linera foram reeleitos com $64,22 \%$ dos votos e a maioria das cadeiras das duas casas da Assembleia Legislativa Plurinacional foram sido alcançadas pelo Movimiento al Socialismo $(\mathrm{MAS})^{183}$.

Nas eleições de 2009, tanto a Confederación de Pueblos Indígenas de Bolivia (Cidob) quanto o Consejo Nacional de Ayllus y Markas del Qullasuyu (Conamaq) apoiaram os candidatos do MAS. De acordo com as resoluções da Comissão Política do Conamaq, no VI Jacha Tantachawi realizado em agosto daquele ano, o governo indígena reafirmava seu "respaldo ao hermano Evo Morales" e ratificava o "voto de castigo aos partidos tradicionais de direita". Da mesma forma, a Estratégia Eleitoral dos

\footnotetext{
${ }^{181}$ Fonte: Vicepresidencia del Estado Plurinacional de Bolivia. Disponível em: http://www.vicepresidencia.gob.bo/IMG/pdf/ciclo resultados.pdf, consultado em 02/06/2013. ${ }^{182} \mathrm{http}$ ://www.rebelion.org/noticia.php?id=79722, consultado em 12/01/2012.

${ }_{183}$ Fonte: Vicepresidencia del Estado Plurinacional de Bolivia. Disponível em: http://www.vicepresidencia.gob.bo/IMG/pdf/ciclo_resultados.pdf, consultado em 02/06/2013.
} 
Povos Indígenas elaborada pela Comissão Política Técnica da Cidob, em 2009, propunha elaborar uma estratégia de campanha eleitoral com o MAS, incluindo candidatos indígenas nas listas do partido e afirmando a necessidade de enfraquecer os "partidos tradicionais". Garcés, no entanto, aponta que o então presidente da Asamblea del Pueblo Guraní (APG), Wilson Changaray, havia manifestado a vontade da organização em participar das eleições com um instrumento político próprio e que, finalmente, seus representantes foram incluídos nas listas do MAS devido à sua impossibilidade em obter o reconhecimento jurídico necessário (2013: 69).

Em abril de 2010, foram eleitos os governadores departamentais, os prefeitos (alcades) e os representantes das assembleias legislativas departamentais. Na eleição para governadores, o MAS ganhou em Chuquisaca, La Paz, Pando, Cochabamba, Oruro e Potosí; perdendo apenas nos departamentos de Santa Cruz, Tarija e Beni ${ }^{184}$. Nos dois primeiros foram reeleitos Rubén Costas (Verdes) e Mario Cossío (Camino al Cambio) e no Beni ganhou um antigo membro da ADN, de Hugo Banzer, que havia igualmente sido membro do Podemos, mas que concorreu com a sigla Primero el Beni.

Assim, as eleições de 2009 e 2010 marcaram não apenas o fortalecimento do MAS no comando do governo nacional - já que sua votação superava em $11 \%$ o percentual de votos recebidos em 2005 - e do Legislativo, como também uma maior presença nos departamentos.

Apesar da vitória do MAS nas eleições realizadas em dezembro de 2009, os debates que a precederam, para a elaboração da Lei de Regime Eleitoral Transitório, refletiram as tensões dentro do bloco de setores subalternos que indiquei durante as análises do primeiro ciclo de crise política (2000-2005) e do processo de elaboração e

\footnotetext{
${ }^{184}$ Fonte: http://pdba.georgetown.edu/Elecdata/Bolivia/gub10.html, consultado em 14/05/2014. Para os representantes indígenas eleitos por formas próprias para as assembleias departamentais, consultar: http://cejis.org/wp-content/uploads/cejis/publicaciones/13976011000boliviaplurinacional $\% 20 \mathrm{~N} \% \mathrm{C} 2 \% \mathrm{BA} \% 202$.pdf.
} 
modificação do texto constitucional. $\mathrm{O}$ ponto central que opunha o governo às organizações indígenas, notadamente a Cidob, o Conamaq e a APG, era sobre o número de cadeiras da Assembleia Legislativa Plurinacional que deveriam ser ocupadas por representantes indígenas, eleitos por formas próprias. A proposta inicial do Conamaq era que 24 das 130 cadeiras fossem destinadas a esses representantes indígenas, e a Cidob reivindicava 19 (Garcés, 2013: 65). Depois de negociações com a Comissão Mista de Constituição da Câmara de Deputados, o número final ficou acordado em 18. Contudo, a lei transitória foi aprovada em abril de 2009 reduziu o número a sete (ibid.: 66). Segundo Garcés, nesse momento a Cidob se afastou da Conalcam, aliança criada por diferentes organizações para apoiar o "processo de mudança" (ibid.) ${ }^{185}$.

Enquanto vivia em La Paz, em 2012, setores mineiros organizaram uma greve e bloquearam as estradas que ligavam a cidade ao resto do país. Tratava-se de uma disputa entre a Federación Sindical de Trabajadores Mineros de Bolivia (FSTMB) que exigia do governo a nacionalização de $100 \%$ da mina de Colquiri, e representantes da Federación de Cooperativas Mineras (Fencomin). Durante uma manifestação no Prado, principal avenida de La Paz, um mineiro da FSTMB foi morto por um explosivo. As estradas estavam ocupadas, havia manifestações em massa no centro da sede do governo, contudo, a crise política multisetorial dos anos anteriores havia sido superada. A presença diária nos meios de comunicação do Ministro de Governo ${ }^{186}$, Carlos Romero, e seu vice, indicavam a importância da mobilização mineira, entretanto, mais do que apontar a possibilidade de uma nova crise política, ela evidenciava a existência de disputas que são constantes na Bolívia mesmo em períodos “ordinários".

\footnotetext{
${ }^{185}$ Garcés explica que funcionários do governo justificavam a nova decisão com o argumento de que o número de cadeiras reivindicado pelas organizações indígenas resultaria em uma "sobrerrepresentação" e, assim, uma violação da constituição (2013: 68). Naquele momento, Pedro Nuni, então vice-presidente da Cidob, declarava ao periódico La Razón: "lamentavelmente, a oposição e o oficialismo se colocaram de acordo para nos despojar no nosso direito à participação" (ibid.: 49, tradução minha).

${ }^{186} \mathrm{O}$ ministro de governo seria o equivalente a um ministro de interior.
} 
Em dezembro de 2010, o embate entre sociedade e Estado viera à luz quando o vice-presidente García Linera assinou um decreto que aumentava o preço da gasolina e do diesel, fortemente subvencionados na Bolívia. Depois de grandes manifestações populares em diferentes regiões do país, e de uma grande mobilização em El Alto contra o decreto, este foi finalmente anulado pelo presidente Evo Morales, no dia 31 de dezembro, uma semana após o seu anúncio ${ }^{187}$. A derrota do governo foi por ele apresentada como uma prova de que Morales "mandava obedecendo ao povo", como afirmavam os outdoors com a foto do Presidente, espalhados por Cochabamba em março de $2011^{188}$.

Neste capítulo, apresentarei a mudança na relação entre o governo de Evo Morales e as organizações indígenas, uma vez superada a crise política multisetorial. Foi em um novo contexto, de maior estabilidade institucional, que foi promulgada em 2010 a Lei Marco de Autonomias e Descentralização Andrés Ibañez, acusada por muitos atores entrevistados de criar novos "cadeados" à implantação da autonomia indígena. Durante a elaboração da lei, como apresentarei a seguir, houve um importante embate opondo a Cidob e o Conamaq ao governo. Essa ruptura, entretanto, tornou-se evidente, em 2011, durante a realização da VIII Marcha Indígena contra a construção de uma estrada que cruza o Território Indígena e Parque Nacional Isiboro Sécure (Tipnis). Quando cheguei a La Paz, em 2012, propagandas do governo com a imagem do presidente Evo Morales não eram raras nas ruas da cidade, mas, igualmente frequentes, eram os grafites em defesa do Tipnis.

Com o enfraquecimento da oposição dos governos da Meia Lua, após a inclusão da autonomia departamental na nova Constituição, e com a maioria alcançada pelo

\footnotetext{
${ }^{187}$ http://www.bbc.co.uk/mundo/noticias/2011/01/110101_bolivia_reacciones_gasolinazo_precio_decreto anulacion_fp.shtml, consultado em 02/05/2014.

${ }^{188}$ Durante o primeiro mandato, Evo Morales havia feito outras referências ao lema zapatista.
} 
MAS nas duas câmaras da Assembleia Legislativa Plurinacional, nas eleições de dezembro de 2009, o foco da polarização política parecia ter se deslocado. Apresentarei neste capítulo como a divisão no interior da Cidob e do Conamaq foi um dos resultados dessa polarização.

O processo de construção da autonomia indígena na Bolívia manteve-se como um espaço de disputa e concertação, não apenas com aqueles atores que sempre se colocaram contra este projeto, mas igualmente entre as organizações e o governo e entre as comunidades indígenas e o Estado. A promulgação da nova Constituição foi um passo fundamental, mas não definitivo, na construção do novo Estado boliviano "Unitário Social de Direito Plurinacional Comunitário, livre, independente, soberano, democrático, intercultural, descentralizado e com autonomias". As novas regras indicavam que uma nova lógica estatal deveria ser criada, mas, este processo ocorreria a partir de instituições e lógicas que haviam sobrevivido ao período de grave crise política vivido nos anos precedentes.

\subsection{A disputa pelos marcos da autonomia indígena}

Em agosto de 2009, em Camiri, cidade do Chaco boliviano onde se encontra a sede da Asamblea del Pueblo Guaraní (APG), o presidente Evo Morales promulgou um decreto supremo que regulamentava a disposição da Lei de Regime Eleitoral Transitório “estabelecendo os requisitos e procedimentos para a convocação e realização do referendo municipal de consulta para adotar a condição de Autonomias Indígena Originário Camponesas, a ser realizado em 6 de dezembro de 2009"189. Naquele evento estavam presentes representantes da organização guarani, do Conamaq, da Cidob, da

\footnotetext{
${ }^{189}$ Decreto Supremo 231, 2 de agosto de 2009. Disponível em: http://www.lexivox.org/norms/BO-DSN231.xhtml, consultado em 09/05/2014.
} 
CSUTCB, da organização de mulheres camponesas "Bartolinas" e da organização dos povos interculturais (antigos "colonizadores"), além de indígenas convidados de outros países da América Latina ${ }^{190}$.

A conversão de municípios é uma das vias previstas pela Constituição para a conformação de uma autonomia indígena originário camponesa (AIOC). A segunda é a conversão de Territórios Indígena Originário Camponeses, formados a partir de um processo burocrático pelo qual devem passar as Terras Comunitárias de Origem (TCOs) - título agrário criado com a Lei Inra na década de 1990. A Constituição define procedimentos distintos para as duas vias de conversão à AIOC. No caso de um território indígena originário camponês, a sua população pode optar pela mudança por meio de procedimentos próprios, já no caso dos municípios, um referendo é organizado pelo órgão eleitoral.

Nas eleições de dezembro de 2009, a população de 12 municípios foi consultada e, em 11 deles, foi aprovada a conversão à AIOC:

1. Charagua; departamento de Santa Cruz; povo/naçãoIOC guarani; língua guarani; 24.427 habitantes.

2. Huacaya; departamento de Chuquisaca; povo/nação IOC guarani; língua guarani; 2.345 habitantes.

3. Chayanta; departamento de Potosí;povo/nação IOC qhara qhara, língua quéchua; 14.165

4. Tarabuco; departamento de Chuquisaca; povo/nação IOC yampara; língua quéchua; 19.554 habitantes.

\footnotetext{
${ }^{190} \mathrm{http}: / /$ www.cipca.org.bo/index.php?option=com content\&view=article\&id=1703\&catid=85\&Itemid=1 24, consultado em 09/05/2014.
} 
5. Mojocoya; departamento de Chuquisaca; povo/nação IOC quéchua; língua quéchua; 7.926 habitantes.

6. Charazani; departamento de La Paz; povo/nação IOC kallawaya; língua aymara; 9.262 habitantes.

7. Jesús de Machaca; departamento de La Paz; povo/nação IOC aymara, língua aymara; 13.247 habitantes.

8. San Pedro de Totora; Oruro; povo/nação IOC jach `ea karangas, língua aymara, 4.941 habitantes.

9. Pampa Aullagas; Oruro; povo/nação IOC jatun killakas; língua aymara; 2.975 habitantes.

10. Salinas de Garci Mendoza; departamento de Oruro; povo/nação IOC jatun killka asanaquis, língua aymara; 8.723 habitantes.

11. Chipaya; departamento de Oruro; povo/nação IOC uru chipaya; língua uru chipaya; 1.914 habitantes $^{191}$.

O fato do referendo ter sido realizado em apenas 12 municípios pode ser entendido a partir da apresentação feita por Xavier Albó (2012 b) sobre o processo no município de Gutierrez, em Santa Cruz, onde o referendo não foi realizado, apesar da mobilização da APG. A primeira dificuldade a ser superada para que Gutiérrez pudesse participar do referendo era o recolhimento da assinatura de $10 \%$ dos votantes em um curto espaço de tempo. Tendo em vista a baixa densidade demográfica da maioria dos

\footnotetext{
${ }^{191}$ Fonte: Elaboração pessoal a partir de diferentes documentos do Ministerio de Autonomías.
} 
municípios rurais na Bolívia ${ }^{192}$, suas grandes dimensões territoriais e a precariedade de meios de transporte e vias de acesso, é possível entender como, em muitos municípios, apenas com algum recurso, e não sem dificuldade, o recolhimento das assinaturas necessárias poderia ser realizado em um curto espaço de tempo. A segunda dificuldade encontrada pela APG em Gutiérrez foi conseguir as assinaturas do prefeito e do conselho municipal para a convocação do referendo. Sem dúvida, essa era uma possível dificuldade que as organizações indígenas poderiam ter encontrado em outros municípios onde não houvesse consenso com as autoridades locais sobre o projeto de conversão à AIOC.

Outra razão que pode explicar o fato da autonomia indígena ter sido aprovada em apenas onze municípios em 2009 é a ausência, naquele momento, de um marco normativo que regulasse o processo. A Constituição indicava que uma lei deveria regular pontos importantes da autonomia indígena. Quando, em 2009, doze municípios foram ao referendo para decidir sobre a autonomia indígena, essa lei ainda não havia sido promulgada. Tal fato demonstra que a nova institucionalidade continuava em processo de formação e disputa.

Além da Lei Marco de Autonomias, outras cinco leis centrais para a organização do Estado plurinacional deveriam ser aprovadas nos seis meses que seguiram a promulgação da nova Constituição.

Segundo um senador do MAS que participou dos debates em torno da nova lei de autonomias, "o mais forte da conformação das autonomias se deu na Lei Marco de

\footnotetext{
${ }^{192}$ De acordo com a Constituição, as AIOCs podem ser formadas apenas na região rural, o que pode ser interpretado como uma importante limitação dado que municípios como El Alto, onde a população é predominantemente indígena, ficam excluídos.
} 
Autonomia e Descentralização, como uma tarefa pendente da constituinte"193. O

Senador descreve os debates em torno da elaboração da lei:

A Lei Marco contou, na realidade, com dez versões preliminares. E cada uma delas foi submetida a um exame e esse exame incluiu eventos departamentais, municipais, com cada uma das organizações matrizes dos povos indígenas, o que permitiu ao mesmo tempo mudar um rascunho por outro. Para afinar delicados consensos. Foi então uma lei amplamente discutida em todo o país. Mas, chegou um momento, quando a Assembleia Legislativa Plurinacional queria contar com um documento definitivo, porque tínhamos prazos peremptórios para aprovar a Lei Marco. Não podíamos passar de julho de 2010 para aprovar a Lei Marco. Foi nesse momento que se apresentou o último rascunho, mas ainda havia alguns problemas, com alguns governos departamentais, alguns municípios, especialmente as capitais departamentais, e algumas pendências com os povos indígenas das Terras Baixas [...] Havia alguns problemas para o acesso à autonomia para aqueles povos que são evidentemente uma minoria étnica no país. E essa discussão se concentrou em alguns artigos, especialmente naqueles sobre o acesso à autonomia indígena e, particularmente, no artigo 54 da Lei Marco [sobre a aprovação do estatuto autonômico ou carta orgânica]. Então havia várias demandas por parte de alguns povos indígenas das Terras Baixas. Não puderam colocar-se de acordo com o Ministério de Autonomias. Foi a Assembleia Plurinacional, em realidade, a senadora Gabriela Montaño e o senador Adolfo Mendoza Leigue os que foram até a VII Marcha, trabalharam com eles durante o dia, durante a noite. Foram feitos acordos e se retornou a La Paz e com esses acordos se aprovou na comissão o projeto final de Lei Marco de Autonomia e Descentralização.

A fala do senador faz referência à VII Marcha Indígena realizada entre junho e julho de 2010. A "Marcha em Defesa do Território, da Autonomia Indígena e dos Direitos dos Povos Indígenas" foi organizada pela Cidob, e apoiada pelo Conamaq, durante os debates para a elaboração da Lei Marco de Autonomias e Descentralização (LMAD) na Assembleia Legislativa Plurinacional. Na plataforma de demandas apresentada pela direção da marcha, reivindicava-se a incorporação ao projeto de Lei

${ }^{193}$ Entrevista realizada em La Paz, outubro de 2012. 
Marco de Autonomias da "proposta dos povos indígenas sobre autonomia indígena trabalhada nas instâncias orgânicas da Cidob" e que autonomias indígenas pudessem ser conformadas "sem limite de número de habitantes nem medição de capacidades e outros requisitos que impossibilitam o acesso à autonomia indígena"; demandava-se o respeito dos limites dos territórios indígenas titulados no momento de sua conversão à autonomia ${ }^{194}$ e que "o Estado proveja os recursos econômicos às autonomias indígenas para o exercício de todas as competências que assumam em seus estatutos"; insistia-se na defesa do direito à consulta que têm os povos indígenas; e, exigia-se que a criação dos Territórios Indígena Originário Camponeses (TIOCs) “em nenhum caso implique ou se interprete como copropriedade indígena e camponesa sobre TCOs"; dentre outras demandas ${ }^{195}$.

Essa pauta de reivindicações apresentada pela Cidob refletia a interpretação da organização - e que neste ponto coincidia com aquela do Conamaq e da APG - sobre as autonomias indígena originário camponesas: uma autonomia que fosse minimamente limitada pelo Estado, mas cuja viabilidade fosse garantida por ele.

Após a ruptura nos diálogos com o governo, a VII Marcha indígena partiu de Trinidad no dia 21 de junho de 2010 em direção a La Paz, com aproximadamente 400 integrantes. Adolfo Chávez, presidente da Cidob, explicava que a ruptura nas negociações havia ocorrido em função da recusa do governo em aceitar que os estatutos autonômicos indígenas fossem aprovados por uso e costume e porque "não se respeitou

\footnotetext{
${ }^{194}$ Como apontei no capítulo 2, muitas vezes as fronteiras das TCOs ultrapassam limites municipais e, algumas vezes, departamentais. A Constituição modificada pelo Congresso em 2008 indicava os procedimentos que os territórios indígenas que ultrapassem fronteiras municipais deveriam tomar caso quisessem converter-se em AIOC.

${ }^{195} \mathrm{http} / / / \mathrm{www}$.cidob-bo.org/images/2010/demandas2010.pdf, consultado em 09/05/2014. As demandas incluíam igualmente a distribuição de terras fiscais para os povos indígenas. A disputa sobre a nova lei de terras também era foco da disputa do governo com os indígenas das Terras Baixas, ver: http://constituyentesoberana.org/3/docsanal/072010/ftierra-marzo.pdf, consultado em 17/05/2014.
} 
o direitos dos povos indígenas em relação à dotação de recursos para exercer sua autonomia"196.

Oito organizações regionais da Cidob iniciaram a marcha ${ }^{197}$. Quatro dias mais tarde, a CPESC anunciou que se uniria à mobilização, apesar de sublinhar que apresentaria uma plataforma de demandas própria, já que discordava de algumas reivindicações da $\operatorname{Cidob}^{198}$. A grande ausente na VII Marcha foi a APG. Em maio, a organização guarani organizara um bloqueio de estradas para que o governo reconhecesse o direito à consulta garantido pela Constituição aos povos indígenas, a consolidação do território indígena e o combate à poluição ambiental provocado por atividades petroleiras $^{199}$. No dia 15 de junho, a APG assinou um acordo com o governo $^{200}$.

As organizações das Terras Altas também estavam divididas no apoio à mobilização. De um lado, os cocaleiros advertiam que não deixariam a marcha passar por seu território, de outro, o Conamaq declarava o apoio às demandas e ameaçava cercar a sede do governo ${ }^{201}$. Dois dias depois de iniciada a marcha da Cidob, Gabino Apata, Apu Mallku do Conamaq, declarava que a organização rechaçava o projeto de lei

\footnotetext{
${ }^{196}$ Fonte: Erbol. Disponível em: http://constituyentesoberana.org/3/docsanal/072010/ftierra-mayo2.pdf, consultado em 17/05/2014.

${ }^{197} \mathrm{http}: / /$ www.lostiempos.com/diario/actualidad/politica/20100623/marcha-indigena-continua-y-evoadvierte-a-usaid_76864_144221.html, consultado em 09/05/2014.

${ }^{198}$ Fonte: Erbol. Disponível em: http://constituyentesoberana.org/3/docsanal/072010/ftierra-junio2.pdf, consultado em 17/05/2014.

${ }^{199} \mathrm{http}: / /$ constituyentesoberana.org/3/docsanal/072010/ftierra-mayo2.pdf, consultado em 19/05/2014. Em território guarani encontram-se grande parte das reservas de hidrocarbonetos da Bolívia. Em visita a uma comunidade guarani perto de Camiri, em novembro de 2013, pude observar o descuido com os resíduos provenientes da exploração desses recursos.

${ }^{200}$ Fonte: Erbol. Disponível em: http://constituyentesoberana.org/3/docsanal/072010/ftierra-junio2.pdf, consultado em 17/05/2014.

${ }^{201}$ http://alainet.org/active/39190\&lang=es, consultado em 09/05/2014.
} 
do governo, pois, apesar das diferentes reuniões com autoridades do Conamaq, as propostas dos indígenas não teriam sido consideradas ${ }^{202}$.

Representantes do governo acusaram organizações que participavam da VII Marcha de serem financiadas pela Usaid ${ }^{203}$. O trabalho da agência estadunidense era conhecido naquele momento por financiar a oposição aos governos de Cuba, Venezuela, Equador e Bolívia, com seus programas de promoção à democracia (cf. Pannain, 2008). Em resposta, Alejando Almaráz, ex-ministro de terras de Evo Morales, em carta assinada em junho de 2010, acusou o governo de violar os direitos constitucionais indígenas e denunciou a tentativa do governo de deslegitimar a marcha ${ }^{204}$.

Com o passar dos dias, novos atores declararam seu apoio à marcha da Cidob. No dia 27 de junho, os deputados das circunscrições especiais indígenas da Assembleia Legislativa Plurinacional declararam greve de fome em solidariedade à mobilização ${ }^{205}$. Nas primeiras semanas de julho, yuquis, yuacarés e outros indígenas do departamento de Cochabamba e dirigentes da nação qhara qhara, do Altiplano boliviano, afirmavam igualmente seu apoio à VII Marcha.

No dia 10 de julho, o presidente Morales se reuniu com as organizações da Coordinadora Nacional por el Cambio (Conalcam), base de apoio ao governo, para analisar a conjuntura política ${ }^{206}$. Embora não falasse por todas as organizações-membro da coordenadora, o então presidente da Conalcam declarou que a marcha estaria

\footnotetext{
${ }^{202}$ Fonte: Los Tiempos. Disponível em: http://www.lostiempos.com/diario/actualidad/politica/20100623/el-conamaq-rechaza-la-ley-marco-deautonomias-y-anuncia 76938 144374.html, consultado em 10/05/2014.

${ }^{203}$ Fonte: Agencia Boliviana de Informação. Disponível em: http://constituyentesoberana.org/3/docsanal/072010/ftierra-junio2.pdf, consultado em 17/05/2014. ${ }^{204}$ Fonte: Bolpress, 30/06/2010.

${ }^{205}$ Fonte: Erbol. Disponível em: http://constituyentesoberana.org/3/docsanal/072010/ftierra-junio2.pdf, consultado em 17/05/2014.

${ }^{206}$ Fonte: Los Tiempos. Disponível em: http://www.lostiempos.com/diario/actualidad/nacional/20100710/presidente-morales-y-organizacionessociales-analizan-coyuntura $79666150740 . \mathrm{html}$, consultado em 10/05/2014.
} 
deslegitimada e que buscava confronto com os camponeses ${ }^{207}$. As tensões entre indígenas e camponeses tornaram-se evidentes em março de 2010, quando a CSUTCB pediu uma revisão dos territórios indígenas e uma maior equidade na distribuição de terras entre indígenas e camponeses, acusando os primeiros de quererem constituir "latifúndios", devido às grandes extensões territoriais reivindicadas ${ }^{208}$.

A resolução do conflito apresentada na entrevista citada anteriormente com o senador do MAS é corroborada pelo pronunciamento público da VII Marcha de 23 de julho de 2010. No documento, o Ministro de Autonomias é acusado de não se dispor a dialogar com as organizações indígenas e de criar falsas acusações com o intuito de deslegitimar a mobilização. Por outro lado, o documento, assinado pelos presidentes das organizações presentes na marcha, reconhece que algumas de suas demandas, no que concerne as autonomias indígenas, foram incluídas na Lei Marco, graças às negociações com os senadores Adolfo Mendoza e Gabriela Montaño ${ }^{209}$. A marcha então foi desmobilizada em Santa Cruz, um mês depois de seu início.

Um ponto importante em que a Lei Marco avançou em relação à Constituição foi a instituição da obrigatoriedade dos conselhos municipais e prefeituras em referendar as assinaturas que convoquem um referendo sobre a conformação de autonomias indígenas. Entretanto, a ideia de que a Lei Marco de Autonomias e Descentralização limita a autonomia indígena é muito forte no discurso dos representantes das organizações indígenas. Algumas das reivindicações apresentada pela Cidob durante a VII Marcha, e que não foram atendidas nas negociações com o governo e os representantes do Legislativo, são apontadas por atores entrevistados como "cadeados"

\footnotetext{
${ }^{207}$ Fonte: Los Tiempos. Disponível em: http://www.lostiempos.com/diario/actualidad/nacional/20100711/sectores-masistas-cierran-filas-contraindigenas 79783 150996.html, consultado em 10/05/2014. ${ }^{208}$ http://constituyentesoberana.org/3/docsanal/072010/ftierra-marzo.pdf, consultado em 11/05/2014. ${ }^{209}$ http://www.cidob-bo.org/images/2010/23\%20de\%20julio.pdf, consultado em 02/06/2012.
} 
da Lei Marco, que dificultariam a implantação da autonomia indígena. Dentre estes “cadeados" estariam a exigência de um limite populacional, o respeito às fronteiras departamentais e a necessidade de um "certificado de ancestralidade", que garanta aos povos e nações indígenas terem seus direitos presentes na Constituição reconhecidos.

A partir da promulgação da Lei Marco, as autonomias indígenas ficaram limitadas às fronteiras departamentais ${ }^{210}$ e ficou estabelecido que apenas Unidades Territoriais com uma população superior a dez mil habitantes (ou quatro mil, em casos especiais) poderiam constituir uma autonomia indígena no Altiplano, e mil, no caso das Terras Baixas.

A impossibilidade de se constituir autonomias que ultrapassem fronteiras departamentais é sem dúvida um importante limite para algumas populações indígenas. Quanto ao respeito do limite populacional imposto pela Lei Marco, apesar de alguns representantes indígenas das Terras Baixas questionarem os limites populacionais presentes na lei, os números apresentados foram resultado de negociações com o governo. Entre nenhum limite, como era reivindicado pelas organizações indígenas, e um limite, imposto pelo Estado, que impossibilitasse muitos territórios a conformarem uma autonomia indígena, apareceu na Lei Marco um resultado negociado. No caso das Terras Altas, são exatamente os números negociados entre o Ministério de Autonomias e o Conamaq em $2010^{211}$. No caso das Terras Baixas, a proposta inicial do governo era de uma população mínima de três mil habitantes (Garcés, 2013: 81). Contudo,

\footnotetext{
${ }^{210}$ Garcés explica que a Constituição não proíbe explicitamente a mudança nas fronteiras departamentais para a autonomia indígena, mas apenas para a definição das circunscrições eleitorais especiais. O limite departamental teria sido imposto apenas a partir da Lei Marco, em seu artigo 29, III (2013: 75). Sendo assim, o argumento do governo durante as negociações com a Cidob de que seria inconstitucional sua reivindicação de que limites espaciais não fossem impostos às autonomias indígenas não seria verdadeiro. ${ }^{211} \mathrm{O}$ acordo assinado pelo Ministro Carlos Romero e outros representantes do Ministério e pelas autoridades do Conamaq está disponível em: http://constituyentesoberana.org/3/noticias/autonomias/062010/300610 3.pdf, consultado em 17/05/2014.
} 
atualmente, representantes tanto da Cidob e quanto do Conamaq questionam a existência desses limites como uma restrição de seu direito.

De fato, parece incoerente que municípios possam ser transformados em AIOCs, sem nenhum limite populacional, e que para a conversão de territórios em autonomias, esses limites estejam presentes. Neste sentido, a Lei Marco facilita a manutenção das fronteiras de organização territorial do antigo Estado.

Segundo Garcés, durante a elaboração da Lei Marco, era possível identificar duas posições claras entre o governo e as organizações indígenas: "da parte do primeiro era evidente a vontade de reduzir os alcances da autonomia indígena, enquanto por parte das organizações demanda-se autonomia plena" (2013: 74, tradução minha).

Sobre a Lei Marco, Iván Égido, que trabalha com a Fundación Tierra, uma das principais ONGs que assessoram municípios que se encontram atualmente em processo de conversão a autonomias indígenas, opina:

\begin{abstract}
A LMAD limita claramente em excesso as competências constitucionais dos eventuais governos indígena originário camponeses. Consequentemente, com esta leitura, pode-se afirmar que os artigos analisados da LMAD desconhecem o marco constitucional e fazem uma interpretação do mesmo que se ajusta a necessidades específicas das instituições estatais (que propõe criar); e não às necessidades daqueles diretamente afetados: os povos indígena originário camponeses, vulnerando os artigos 13 e 256 da Constituição Política do Estado (2010: 282-3; tradução minha).
\end{abstract}

Os limites presentes na lei, interpretados pelas organizações indígenas e por representantes de ONGs como "cadeados", são justificados pelo atual vice-ministro de autonomias, Gonzalo Vargas, como uma forma de manter a ordem e garantir a viabilidade do processo de construção de autonomias indígenas. Para Vargas, as normas 
são importantes porque viabilizam o processo de autonomias indígenas. Por exemplo, a demanda de limites populacionais mínimos se mostraria pertinente a partir da experiência histórica de municípios muito pequenos que apresentam uma gestão ineficiente. Segundo Gonzalo Vargas, a solução para os grupos indígenas que tenham uma população inferior à estipulada pela Lei Marco seria a criação de distritos indígena originário camponeses, que, apesar de não conformarem uma autonomia indígena, teriam uma administração própria e a possibilidade de se unirem para formar uma região. Igualmente, falando dos dois projetos civilizatórios que existem hoje na Bolívia, Vargas aponta a importância da existência de "regras do jogo", para que a colisão entre os direitos individuais e os direitos coletivos "não termine permanentemente em enfrentamento". É com essa perspectiva que devemos entender a diferenciação que o vice-ministro faz entre a autonomia de facto e a AIOC, sendo a segunda o resultado de um consenso com a sociedade em seu conjunto. Neste sentido, regras seriam necessárias para estabelecer critérios de solidariedade, de apoio e articulação com a sociedade não indígena, ele argumenta. Contudo, Vargas explica que atualmente o ministério está trabalhando para facilitar a conversão à autonomia, revisando algumas normas procedimentais, para torná-las mais simples ${ }^{212}$.

Para a ministra de autonomias, Claudia Peña, a Lei Marco tem um enfoque que privilegia a conformação de autonomias indígenas sobre a forma republicana. Contudo, a ministra concorda com Gonzalo Vargas quando aponta a possibilidade de flexibilização das normas estatais e trâmites burocráticos para facilitar a conversão de entidades territoriais em autonomia indígena ${ }^{213}$.

Adolfo Mendoza, senador pelo MAS, destaca que o papel do nível central do Estado seria fortalecer a construção de autonomias, garantindo os recursos necessários

\footnotetext{
212 Entrevista realizada em La Paz, dezembro de 2013.

${ }^{213}$ Entrevista realizada em La Paz, dezembro de 2013.
} 
e, ao mesmo tempo, "impedir que os governos autônomos possam privilegiar o interesse particular de cada autonomia por cima do bem comum”. Assim, Mendoza argumenta que "há uma necessidade de apoio para a organização territorial do Estado, [e] ao mesmo tempo, de contenção daquelas tendências que tentem lesionar o comum que nos une e o caráter unitário do Estado Plurinacional"214.

Apesar das diferentes interpretações sobre a necessidade dos limites presentes na Lei Marco de Autonomias e Descentralização, em um ponto os representantes das organizações indígenas e a atual ministra de autonomias e seu vice-ministro de autonomias indígenas concordam: o debate sobre as autonomias indígenas não é uma prioridade no campo político boliviano atual.

Se, em 2009, no encontro de lançamento das autonomias indígenas, em Camiri, a cúpula da CSUTCB esteve presente; em setembro de 2012, não havia interesse por parte de seus dirigentes na autonomia indígena, como explicava um antigo secretário geral da organização camponesa:

Mas no ambiente está que o Conamaq é o que está empurrando as autonomias indígenas, portanto a federação [Federação Departamental de La Paz, membro da CSTUCB] não pode apoiar a autonomia indígena, somente a autonomia municipal. E se isso saísse como resolução departamental, então há pouca possibilidade de que outros municípios possam ter a sua autonomia indígena. Porque vão tomar como um mandato do nível de organização departamental para que os outros possam implementar. O que sentem estas instâncias de dirigentes, há uma sintonia com o governo. Se é uma decisão adotada dessa natureza, então tem o aval do governo, é um pouco a imagem. [...] De verdade, veem o Conamaq como aquele que quer a autonomia indígena. Então os afiliados da CSUTCB vão dizer nós não aceitamos isso ${ }^{215}$.

\footnotetext{
${ }^{214}$ Entrevista realizada em La Paz, outubro de 2012.

${ }^{215}$ Entrevista realizada em La Paz, setembro de 2012.
} 
A observação do antigo dirigente foi corroborada em um encontro que tive com um atual dirigente da CSUTCB. A princípio, ele havia negado meu pedido de entrevista sobre o processo de construção das autonomias indígenas no país, quando finalmente aceitou, perguntou se eu queria falar sobre o Tipnis. Ele fazia referência a um conflito que tornaria evidente as disputas entre as organizações indígenas, Cidob e Conamaq, de um lado, e de outro, o governo central e as organizações camponesas.

\subsection{A luta indígena pela consulta}

Dentre as reivindicações da VII Marcha Indígena liderada pela Cidob e aquelas presentes nas negociações da APG com o governo, em 2010, estava a garantia do direito, reconhecido pela Constituição, à consulta prévia aos povos e nações indígenas, quando medidas legislativas ou administrativas possam afetá-los. Em 2011, quando as organizações do Território Indígena e Parque Nacional Isiboro Sécure (Tipnis) e a Cidob organizaram a "VIII Marcha Indígena pela Defesa do Tipnis, pelos Territórios, pela Vida e pelos Direitos dos Povos Indígenas”, a discussão sobre o direito dos povos indígenas à consulta prévia tornou-se central no debate político nacional. A VIII Marcha questionava o trajeto da estrada que deveria ligar as cidades de San Ignacio de Moxos, no departamento do Beni, a Vila Tunari, em Cochabamba, cruzando o território do Tipnis. A maior parte do custo da obra seria financiada pelo BNDES, fato que é usado por aqueles que são contra a sua construção para argumentar que o principal interessado na obra seria o governo brasileiro e não a população boliviana. Sobre os diferentes interesses envolvidos na construção da estrada, Moraes explica:

Há interesses de pelo menos quatro ordens diferentes que estariam relacionados com a estrada: interesses locais, dos segmentos do Tipnis que concordam com a estrada; interesses regionais, que envolvem os fazendeiros do Beni e os cocaleros do Chapare, 
bem como os políticos do MAS no departamento de Beni; interesses nacionais relacionados com um projeto de país integrado e desenvolvido, e com a vontade dos líderes do MAS de isolar economicamente o departamento oposicionista de Santa Cruz; e interesses internacionais, vinculados, principalmente, com os projetos da Iniciativa para a Integração da Infraestrutura Regional Sul-Americana (IIRSA), com os interesses do Brasil no projeto e com a atenção das demandas mercantis de empresas transnacionais (2014: 58).

A VIII Marcha partiu de Trinidad, no departamento do Beni, em direção a La Paz, no dia 15 de agosto de 2011, com aproximadamente 700 integrantes $^{216}$. No dia 20 de setembro, em uma conferência de impressa, o vice-presidente Álvaro García Linera explicava a importância da estrada desde o ponto de vista do governo:

Esta estrada é o último toque do desmanche das pretensões separatistas da Bolívia que queria separar um pedaço da Bolívia do resto, essa estrada é como uma sutura para unir regiões. O Oriente tem que estar unido ao Vale, o Vale unido ao Altiplano, e o Altiplano unido à Amazônia. Essas estradas são encaixes territoriais e geopolíticos que vão garantir a base material da unidade boliviana nos próximos 50 a 100 anos (tradução minha) $)^{217}$.

Segundo o vice-presidente, a importância da estrada estaria igualmente relacionada à necessidade da população do Tipnis e ao desenvolvimento do departamento do Beni.

\footnotetext{
${ }^{216}$ Organizações indígenas que iniciaram a VIII Marcha: Confederación de Pueblos Indígenas de Bolivia (Cidob); Subcentral Tipnis; Asamblea del Pueblo Guaraní (APG); Central de Pueblos Indígenas del Beni (CPIB); Central Indígena de la Región Amazónica de Bolivia (Cirabo); Central de Pueblos Indígenas de La Paz (CPILAP); Consejo Nacional de Ayllus y Markas del Qullasuyu (Conamaq); Organización Indígena Chiquitana $(\mathrm{OICH})$; Subcentrales Bella Selva, Cercado, Río Mamoré y Río Isiboro; Central de Pueblos Étnicos Mojeños del Beni (CPEM-B); Confederación Nacional de Mujeres Indígenas de Bolivia (CNAMIB); Subcentral de Comunidades Indígenas Sécure-Tipnis; e Central de Mujeres Indígenas del Beni (CMIB). Organizações que se incorporaram ao longo da Marcha: Central Indígena de Pueblos Amazónicos de Pando (Cipoap), Central de Pueblos Indígenas del Trópico de Cochabamba (CPITCO), Territorio Indígena Multiétnico (TIM), Territorio Indígena Mojeño Ignaciano (Timi). "A resolução de convocação à mobilização, aprobada pela Confederación de Pueblos Indígenas de Bolivia (Cidob), instruía a participação dos 34 povos indígenas do Oriente, Chaco e Amazônia, além das centrais, subcentrais, conselhos e cabildos comunais" (Fundacíon Tierra, 2011b: 58).

${ }^{217} \mathrm{http}$ ://www.vicepresidencia.gob.bo/Garcia-Carretera-por-el-TIPNIS, consultado em 20/05/2014.
} 
A mobilização evidenciou uma ruptura das organizações locais do Tipnis, entre um grupo mais crítico e outro mais próximo do governo. O primeiro era conformado pelas Sub-Centrais do Tipnis e do Sécure ${ }^{218}$, e, o outro era representado pelo Consejo Indígena del Sur (Conisur), representante dos camponeses que vivem dentro do território indígena e se dedicam, principalmente, ao cultivo da coca.

Em diferentes momentos, durante as primeiras semanas da marcha, o governo enviou representes para negociar com os indígenas mobilizados; as lideranças indígenas exigiam, contudo, a presença de Evo Morales (Fundación Tierra, 2011b: 63). O presidente Evo Morales jamais foi encontrar-se com os representantes das organizações indígenas nos mais de dois meses de marcha, contudo, poucos dias depois dela iniciada, reuniu-se com representantes do Conisur.

Moraes explica que a transformação do Tipnis de Terra Comunitária de Origem (TCO) em Território Indígena Originário Camponês (TIOC) teve implicações importantes para o conflito entre as organizações do território indígena: "se antes a contestação à legitimidade do Conisur era mais fácil de ser compreendida, visto que uma organização de camponeses não poderia responder por um Território Indígena, com a recategorização jurídica da região esse debate fica mais complicado" (2014: 45). A observação da autora corrobora a preocupação de representantes de organizações da Cidob e do Conamaq que entrevistei com o termo "indígena originário camponês".

Em diferentes localidades pelas quais passou a marcha, houve hostilidade por parte dos camponeses que apoiavam a construção da estrada e, em determinado momento, camponeses e colonizadores bloquearam a estrada perto de Yucumo, para impedir a passagem dos manifestantes. Cabe notar que uma das queixas dos indígenas do Tipnis a respeito da rota escolhida para a construção da estrada, seria o fato dela

\footnotetext{
${ }^{218}$ A Sub-Central do Sécure se dividiu durante o conflito.
} 
facilitar a ocupação de terras dentro do parque nacional por cocaleiros, para além da "linha vermelha" que delimita o espaço do parque onde estão localizados os assentamentos camponeses. Segundo Adolfo Moye, ex-presidente da Sub-Central Tipnis:

[Havíamos detectado] até 300 avassalamentos de cocaleiros que plantaram coca dentro do Tipnis. Vimos um desmatamento dramático, não consideraram nem as madeiras úteis para as comunidades, como a jatata [palmeira que serve para construir tetos], que foi arrasada. Quando os dirigentes [da Cidob] souberam desta realidade decidiram apoiar a realização da Oitava Marcha (Fundación Tierra, 2011b: 97, tradução minha).

O governo era acusado de haver se afastado das organizações indígenas e se tornado o governo dos camponeses. No início da marcha, Celso Padilla, presidente da Asamblea del Pueblo Guaraní (APG), havia declarado:

Queremos dizer ao governo que este é o Estado Plurinacional. Aqui estão os 34 povos. Queremos dizer ao presidente Evo Morales que o Estado se constrói com estes povos. Não se deve concentrar o poder somente na CSUTCB, nas „Barolinase e nas comunidades interculturais [antigos colonizadores]. Que estes povos são os que se levantaram e o conduziram ao poder. Por que se esquece tão rápido? (Fundación Tierra, 2011b: 55, tradução minha).

No dia 25 de setembro, o governo reprimiu violentamente manifestantes da VIII Marcha que se encontravam na localidade de Chaparina. Este foi um momento central na ruptura entreo governo e as organizações indígenas, e, ao mesmo tempo, a repressão estatal fortaleceu o apoio de diferentes organizações sociais e de grande parte dos bolivianos à mobilização. Assim, quando, depois de mais de dois meses e 600 quilômetros percorridos, a marcha chegou a La Paz, no dia 19 de outubro, ela foi recebida por uma multidão de centenas de milhares de pessoas. 
A marcha de 2011 evidencia não apenas a ruptura entre o governo e as organizações indígenas participantes, mas, igualmente, entre o governo e diferentes organizações sociais, organizações não governamentais e atores que anteriormente haviam apoiado o proceso de cambio. No dia 10 de setembro, a Federación Sindical de Trabajadores Mineros de Bolivia (FSTMB) publicou uma "resolução de apoio e solidariedade com os companheiros do Tipnis". E, como resposta à repressão em Chaparina, no dia 25, a Central Obrera Boliviana (COB) convocou uma greve geral ${ }^{219}$. O deputado indígena do MAS Pedro Nuni, que já havia se colocado em posição crítica ao governo durante a marcha pela autonomia indígena, declarou na chegada da VIII Marcha à Praça San Francisco, em La Paz:

Nós, os deputados indígenas, assumiremos uma posição de independência como parlamentares indígenas, com voz própria, porque não queremos mais pertencer ao MAS [...] Convoco as organizações de El Alto a retornar à agenda de outubro, inconclusa, e desenvolver uma nova participação política com os povos do Oriente, da Amazônia e do Chaco boliviano. Necessitamos reconduzir o proceso de cambio porque está destorcido pelos oportunistas que rodeiam o Evo. Não viemos derrubar o Evo, queremos fazer uma agenda que permita aos bolivianos não serem escravos de um partido que quer hegemonizar e criar uma ditadura (Paz, 2011: 9, tradução minha) $)^{220}$.

Poucos dias depois da chegada da marcha a La Paz, o governo promulgou a Lei 180, conhecida como "lei curta", que declarava a intangibilidade do território indígena do Tipnis. Contudo, no início de 2012, o Conisur realizaria uma marcha pela instauração de um processo de consulta da população do Tipnis e, ainda que a marcha não tenha recebido o apoio popular comparável àquele recebido pela marcha da Cidob,

\footnotetext{
${ }^{219} \mathrm{http}$ ://www.la-razon.com/index.php? url=/nacional/COB-declara-general-protestaintervencion 01475252525 .html, consultado em 22/05/2014.

${ }^{220}$ Em janeiro de 2013, Pedro Nuni concorreria ao cargo de governador do departamento do Beni contra a candidata do MAS, a ex-Miss Bolivia, Jessica Jordan. Nesta eleição, o MAS recebeu 44,1\%, Pedro Nuni $2,4 \%$ e Carmelo Lens, do opositor "Primero el Beni", ganhou com 52,6\%. Depois da eleição, Nuni anunciou uma aliança com Lens, para ocupar o cargo de subgovernador do departamento.
} 
a mobilização do Conisur resultou na aprovação, em fevereiro, de uma lei de consulta. Como resposta, no dia 27 de abril, as organizações do Tipnis e a Cidob iniciaram a "IX Marcha em Defesa do Território Indígena e Parque Nacional Isiboro Sécure”, contra o projeto de consulta elaborado pelo governo. Durante dois meses, os manifestantes cruzaram o país até chegar à sede do governo central. Mais uma vez, a mobilização contou com a participação do Conamaq ${ }^{221}$.

No entanto, a IX Marcha Indígena não teve o mesmo impacto no cenário político boliviano daquela realizada em 2011. E, em julho de 2012, iniciou-se a consulta às comunidades indígenas e não indígenas do Território Indígena e Parque Nacional Isiboro Sécure. O resultado oficial apresentado pelo governo indica a aprovação da construção da parte da estrada que cruza o Tipnis, contudo, algumas lideranças indígenas acusam o governo de manipular a consulta e o seu resultado. Apesar da consulta realizada, o desgaste político do governo em torno do projeto da estrada foi tão grande que, atualmente, a sua construção está suspensa.

$\mathrm{O}$ direito à consulta parte do mesmo princípio do direito ao autogoverno: o reconhecimento do Estado de sua pluralidade, ou seja, num Estado Plurinacional, as noções de "interesse nacional" ou "bem comum", tão usadas em diferentes países para justificar interesses de alguns setores sociais, carecem de justificativas jurídicas. Todas as nações e povos dentro do Estado boliviano têm direito sobre seu território. Um espaço jurídico presente na constituição é a ausência da indicação do caráter vinculante da consulta aos povos e nações indígenas. Tal ausência implica que mesmo que determinado projeto seja rechaçado na consulta, ele pode ser implantado pelo governo. Contudo, no caso de Tipnis, a questão é que os indígenas não foram previamente

\footnotetext{
${ }^{221}$ http://www.lostiempos.com/diario/actualidad/economia/20120628/los-hechos-de-la-ix-marchaindigena 176596_372601.html, consultado em 18/05/2014.
} 
consultados sobre a construção da estrada que passaria no "coração do parque". Foi um projeto imposto aos indígenas, sem espaço para negociações.

Diferentes atores entrevistados compartilham a percepção sobre uma falta de interesse do governo de Evo Morales em fomentar as autonomias indígenas. As explicações apresentadas foram várias. Uma delas foi o conflito de Tipnis, que mostraria "os perigos" que autonomias indígenas poderiam trazer limitando o poder do governo central. Sobre os conflitos em torno da estrada, um representante da Cidob entrevistado, argumentava: "por isso é importante ter autonomia plena, reconhecida pelo Estado, $^{, 22}$.

Com efeito, a garantia do direito à autonomia indígena esteve presente nas plataformas de demandas da VIII e da IX Marchas Indígenas. Na segunda, pediu-se a modificação da Lei Marco de Autonomias e Descentralização, e, abordando de forma mais específica o tema da autonomia indígena, a plataforma da VIII Marcha afirmava:

Demandamos que o governo do Estado Plurinacional proveja os recursos econômicos para implantação da GTI [Gestão Indígena Territorial] em todos os Territórios Indígenas titulados como meio de ir avançando em direção às autonomias indígenas.

A Lei de Unidades Territoriais a ser aprovada pela Assembleia Legislativa Plurinacional deve possibilitar o acesso às autonomias indígenas em todos os territórios indígenas, sem fazê-las depender da vontade ou interesse político dos governos dos departamentos que manifestadamente demonstraram sua oposição (tradução minha).

No acordo sobre o tema das autonomias indígenas assinado por representantes do governo e das organizações da VIII Marcha, afirmava-se que o Projeto de Lei de Unidades Territoriais seria feito em consenso com a Cidob e o Conamaq, "no marco do acesso às autonomias indígena originário camponesas, em dois eventos nacionais" e o

${ }^{222}$ Entrevista realizada em La Paz, setembro de 2012. 
governo se comprometia a agilizar os trâmites necessários para a declaração de "unidade territorial", "àqueles territórios indígenas que assim o solicitem e tenham cumprido o procedimento de acesso à autonomia indígena originário camponesa". Ademais, declara-se no acordo:

O Governo Nacional através do Ministério de Autonomias concertará e executará um Plano Conjunto que contemple: o desenvolvimento das normas necessárias para o acesso e a implantação das autonomias (rota e conteúdo do pacto fiscal, fim de prazo para a conversão de autonomia municipal a AIOC etc.), recursos econômicos e apoio técnico em coordenação com as organizações indígenas originárias demandantes, com a Cidob, o Conamaq e as instancias deliberativas e legislativas responsáveis. O Governo Nacional seguirá apoiando os órgãos deliberativos de Charagua e Huacaya no término da elaboração de seus Estatutos de Autonomia Indígena Originário Camponesa (tradução minha).

Sobre as demandas das marchas um assessor do Conamaq:

$\mathrm{Na}$ oitava e na nona marcha indígena originária recordou-se ao governo que tem um compromisso político com o Conmaq o qual deve cumprir. [...] E o governo o que diz é que nós somos ambiciosos [...] que somos da direita, tudo isso. Então quando nós, com a proposta da autonomia indígena, fomos ao lado do presidente para que se derrote a direita. Agora resulta que ao contrário, que nós com a autonomia indígena queremos ser igual a Santa Cruz, à direita ${ }^{223}$.

Esta entrevista foi realizada em setembro de 2012, e a fala do representante do Conamaq indica o crescente distanciamento entre o governo e a organização e reflete a percepção compartida por diferentes atores, naquele momento, de que não havia interesse por parte do governo central em apoiar os processos autonômicos indígenas.

${ }^{223}$ Entrevista realizada em La Paz, setembro de 2012. 


\subsection{A reordenação do campo e a divisão das organizações indígenas}

O conflito do Tipnis deixou patente não somente a separação entre organizações indígenas e camponesas, como também, divisões no interior das organizações indígenas. Durante a VIII Marcha, Evo Morales se reuniu com autoridades dos ayllus do Norte de Potosí, considerado um setor dissidente do Conamaq. A APG apareceu igualmente dividida quando seu presidente, Celso Padilla, anunciou que os representantes guaranis que haviam se reunido com o ministro Carlos Romero seriam submetidos a um $\operatorname{processo}^{224}$.

Em 2012, a divisão da Cidob e do Conamaq era incontestável. Em 10 de julho de 2012, foi realizada uma Grande Assembleia dos Povos Indígenas (Gampi) das Terras Baixas, que formou um novo diretório nacional para a Cidob. Adolfo Chávez, que havia sido eleito presidente da organização em 2010, teve seu mandato desconhecido e Melva Hurtado foi eleita presidenta da Cidob. Adolfo Chávez, e parte importante da organização indígena, não reconheceram a nova eleição e acusaram o governo central de fomentar a divisão da organização ${ }^{225}$. Chávez fora uma das principais lideranças indígenas das VII, VIII e IX Marchas Indígenas. Melva Hurtado, que seria apontada como uma espécie de títere do governo na Cidob paralela, é uma autoridade histórica da organização e havia participado ao lado de Chávez da comissão política da VIII Marcha. Desta forma, há, atualmente, uma Cidob mais próxima ao governo, que em outubro de 2012, “coroou” Evo Morales “cacique geral”, e outra, que reconhece o comando de Adolfo Chávez.

O Conamaq, que era formado por 16 suyus ou nações, no final de 2012 representava apenas 13. Em setembro de 2012, em entrevista à Agência Intercultural de

\footnotetext{
${ }^{224}$ http://www.laprensa.com.bo/diario/actualidad/bolivia/20111005/el-gobierno-busca-dividir-aorganizaciones 8369 14109.html, consultado em 02/05/2014.

${ }^{225}$ Os mandatos do diretório da Cidob são de quatro anos.
} 
Notícias Indígenas da Bolívia (Aini-Notícias), a autoridade máxima do Conamaq, o Jiliri Apu Mallku Félix Becerra afirmava: “é com as autoridades de alguns suyus de La Paz que o governo tenta nos dividir [...] busca a desarticulação do Conamaq",226. O controle da direção do Conamaq estava em disputa.

No VII Jach'a Tantachawi realizado em dezembro de 2011, havia sido eleito um novo diretório, que acusava as autoridades anteriores de terem se aproximado demais do governo e do $\mathrm{MAS}^{227}$. Com efeito, uma das estratégias do Conamaq havia sido a ocupação de espaços dentro da estrutura estatal. Como me explicava um antigo assessor da organização, antigos representantes do Conamaq foram trabalhar em diferentes ministérios por "mandato" das autoridades indígenas, para que, a partir de dentro das instituições, pudessem "cuidar de lo indígena".

A disputa no interior do Conamaq culminou com enfrentamentos diante da sede da organização em La Paz, em dezembro de 2013. No dia 10 daquele mês, dois grupos do Conamaq começaram uma disputa pela ocupação da casa onde fica localizada a sede da organização. Naquele dia, um novo diretório havia sido eleito em um encontro com representantes de alguns dos suyus opositores ao comando da organização. A legitimidade dessa eleição era contestada pelo conselho de governo do Conamaq que afirmava que, segundo o estatuto da organização, cabia à autoridade máxima e seu conselho convocar o Jach'a Tantachawi ${ }^{228}$. Em meio à disputa, o VIII Jach'a Tantachawi foi realizado nos 13 e 14 de dezembro, e um novo conselho de governo foi eleito.

\footnotetext{
${ }^{226} \mathrm{http}$ //www.aininoticias.org/2012/09/felix-becerra-dice-que-el-gobierno-quiere-derrocarle-de-su-cargo/, consultado em 18/12/2012.

${ }^{227}$ As autoridades do Conamaq são eleitas a cada dois anos.

${ }^{228}$ Fonte: Comunicado a las 16 naciones originarias del Conamaq y la opinión pública nacional e internacional, 11 de dezembro de 2013. Disponível em: http://www.conamaqkullasuyu.org/wpcontent/uploads/2013/12/COMUNICADO-DEL-CONAMAQ-LEGITIMO-A-LAS-NACIONESORIGINARIAS-Y-LA-OPINION-PUBLICA-NACIONAL-E-INTERNACIONAL-1.pdf, consultado em $17 / 05 / 2014$.
} 
Naquele momento, havia um cerco policial em torno da sede do Conamaq. Esse era justificado pelo governo como necessário para evitar que os grupos rivais se enfrentassem novamente. Algumas autoridades eleitas em 2011 mantiveram-se no interior da casa do Conamaq, no bairro de Sopocachi, contudo, as novas autoridades não podiam aceder à sede em função do cerco policial. Em resposta, as autoridades eleitas no VIII Jach'a Tantachawi iniciaram uma vigília e uma greve de fome na frente à sede da organização.

A casa onde fica atualmente a sede do Conamaq em La Paz foi doada pelo governo de Evo Morales, com o apoio do governo venezuelano, em 2008. O fato do governo central, em 2013, ser acusado de impedir o acesso a essa casa pelos representantes da organização é bastante representativo das mudanças ocorridas no contexto político boliviano nos últimos anos.

No dia 20 de dezembro, ao lado dos dirigentes máximos da CSUTCB e da organização de mulheres camponesas "bartolinas", a autoridade eleita no primeiro encontro de dezembro, acusada de representar os interesses do governo central, anunciou o apoio do Pacto de Unidade ao seu mandato e declarou a intenção de reformular o estatuto do Conamaq ${ }^{229}$. Até o final de 2013, a disputa ainda não havia sido resolvida.

Sem dúvida, as disputas entre diferentes grupos no interior das organizações indígenas e camponesas sempre existiram, como comprovam a separação da CPESC de sua organização matriz, Cidob, no início dos anos 2000, e a existência de dois diretórios paralelos da CSUTCB, no mesmo período. Como foi possível observar durante o período de crise política analisado anteriormente, ainda que as diferenças se

\footnotetext{
${ }^{229} \mathrm{http}: / /$ www.paginasiete.bo/nacional/2013/12/21/bando-afin-toma-facto-control-conamaq-9240.html, consultado em 17/05/2014.
} 
manifestassem, elas eram superadas na construção de grandes alianças. As divergências entre os atores, que reapareceram uma vez ultrapassado o período de crise política, encontraram um ambiente político favorável à intensificação das diferenças, através da intervenção do governo central.

Desde a ascensão do MAS ao governo central, podemos notar diferentes movimentos por parte do governo e dos representantes das organizações indígenas que indicam a complexidade da reconfiguração do campo político boliviano e da relação entre o Estado e os "povos e nações indígena originário camponeses". Esse processo teve grande influência no debate das autonomias indígenas, como vimos até aqui.

Apesar da longa história de autonomias de facto dentro do território boliviano, o reconhecimento estatal das autonomias indígenas é um processo novo e em disputa.

O projeto de "refundação do Estado" boliviano a partir dos setores subalternos a partir de 2006 implica no reconhecimento da diversidade social e política existente na Bolívia, e na expansão do Estado até então percebido como fraco e pouco presente.

Precederam o atual processo, dois outros momentos importantes de expansão estatal na história recente boliviana. Estes dois projetos de expansão estatal, de certa forma, moldaram o modo como a população indígena se relaciona com o Estado, e influenciam o atual processo político. Desta forma, as lógicas criadas em momentos anteriores se refletem na possibilidade de expansão e consolidação de autonomias indígenas.

O primeiro processo de expansão estatal foi resultado da Revolução de 1952, que institucionalizou uma relação entre o Estado e as comunidades rurais por meio dos sindicatos. Como aponta Rivera (2003 [1984]), ao analisar a região dos Vales, essas novas relações eram fortemente baseadas no clientelismo. Ao mesmo tempo, houve uma 
diferenciação interna, "com a emergência de uma camada de camponeses ricos, que diversificam suas atividades para o transporte, o comércio e a usura, e que intervêm ativamente na reorganização mercantil dos Vales, sob a égide do sindicalismo paraestatal" (ibid.: 35, tradução minha). O processo que vive hoje a Bolívia reflete esses dois movimentos apontados por Rivera, a construção de uma relação clientelista entre o poder local e o poder central - que se reproduz igualmente nas diferentes relações locais - e a diferenciação interna do campesinato.

O segundo marco da expansão estatal recente foi a criação dos municípios rurais na década de 1990. Com a mudança, o Estado boliviano expandiu-se igualmente ao reconhecer formas de organização locais autônomas, abrindo-lhes um espaço de participação nas decisões dos recursos estatais, em municípios e Terras Comunitárias de Origem (TCOs). Como afirma Wanderley, “os significados que adquire a personalidade jurídica nos permitem observar como, ao subordinar, o Estado dá poder a atores coletivos" (2009: 597). A autora explica que o "empoderamento se dá na formação de atores que reconhecem o espaço aberto por leis e políticas; atores que se apropriam desses canais formais, que negociam e lutam para exercer os direitos definidos pelo Estado e que, além disso, continuam demandando a extensão de novos direitos" (ibid.).

Esse segundo projeto resultou, igualmente, na ampliação das fronteiras do Estado em direção ao Oriente, incluindo a participação dos setores indígenas das Terras Baixas, que não estavam contemplados no antigo pacto entre o campesinato e o Estado. Penso que a diversidade étnica, social, cultural, econômica e política que encontramos na Bolívia, assim como as diferentes relações construídas entre o Estado e os povos e nações indígenas, dificulta qualquer tentativa de generalização do impacto político nestas relações de programas governamentais. Os impactos são variáveis assim como são as percepções dos atores sobre seus efeitos. Como veremos a seguir, no caso de 
Charagua, as mudanças ocorridas na década de 1990 são interpretadas como insatisfatórias por atores que participam da construção atual da AIOC no município, pois, manteriam os poderes dos partidos políticos.

De diferentes formas, o processo atual de reconhecimento da diversidade social e política vem acompanhado da expansão do Estado boliviano e, em distintos níveis, a expansão estatal tem influência no processo de construção de AIOCs. Mesmo depois da definição de seus marcos legais, a autonomia indígena continua um projeto em disputa.

Destaco alguns aspectos da expansão estatal que têm influência no atual cenário de construção de governos "indígena originário camponeses" autônomos: por meio da maior presença do Estado na economia; na sua maior atuação em diferentes regiões do país, através de programas governamentais e de obras de infraestrutura; na abertura do campo da política institucional a novos atores; na regulamentação de formas de organização relativamente autônomas existentes etc.

Em primeiro lugar, na economia, o Estado se fez mais presente a partir da nacionalização de empresas de diferentes setores estratégicos, como o de telecomunicações e de mineração, ao mesmo tempo em que foram criadas novas empresas estatais. A renegociação dos contratos de exploração dos hidrocarbonetos e o alto preço das matérias primas no mercado internacional, dentre outros fatores, levaram a um aumento significativo dos recursos econômicos em mãos do governo central, que auxiliaram a viabilização dos programas do governo. O total gasto em investimento público passou de 629 milhões de dólares em 2005, para 3 bilhões 781 milhões em $2013^{230}$

\footnotetext{
${ }^{230}$ Fonte: Ministerio de Planificación y del Desarrollo. Disponível em: http://www.vipfe.gob.bo/index.php?opcion=com_contenido\&ver=categoria $v$ vista\&id=604\&idc $=2281 \& \mathrm{id}$ item $=716$, consultado em 20/05/2014.
} 
Por meio do programa "Bolivia hace, Evo cumple", é destinada uma grande quantidade de recursos a obras de infraestrutura em diferentes municípios ${ }^{231}$. A ministra de autonomias Claudia Peña vê nesta maior disponibilidade de recursos econômicos para os municípios uma das razões para terem sido poucos os municípios interessados na conversão à autonomia indígena originário camponesa ${ }^{232}$.

Com efeito, no mesmo momento em que se constitucionaliza o reconhecimento da autonomia, o Estado boliviano, por meio da condução do atual governo central, disponibiliza-se, com uma intensidade inédita, a estar presente na vida dos bolivianos. Entretanto, se por um lado, pode haver um desinteresse em construção de processos autonômicos em um momento que as autoridades locais contam com uma quantidade inédita de recursos, como apontado pela ministra; parece haver igualmente uma dificuldade em conciliar o fortalecimento do Estado, e a consolidação em seu comando pelo setor que representa o MAS, e uma autonomia que implica em menor intervenção do governo.

Em segundo lugar, a expansão do campo da política institucional incluiu atores que antes participavam da política em espaços fora desse campo. A presença de vários homens e mulheres indígenas na Assembleia Legislativa Plurinacional é uma prova dessa inclusão. Um espaço antes praticamente inacessível foi aberto a esses atores. Para os que argumentam que às nações indígenas majoritárias, aymara e quéchua, interessalhes o controle do Estado e não autonomizarem-se deste, a mudança no campo da política institucional pode ser entendida como uma das razões pelas quais, até agora, poucos municípios e territórios indígenas teriam iniciado o processo de conversão à AIOC.

\footnotetext{
${ }^{231}$ Outra preocupação do governo foi com uma melhor distribuição de renda. O governo criou programas de bonificação para idosos, para crianças inscritas no sistema escolar e mulheres grávidas; aumentou o salário mínimo de 55 dólares em 2005 para 172 dólares em 2013; subsidiou alimentos da cesta básica. ${ }^{232}$ Entrevista realizada em La Paz, dezembro de 2013.
} 
No entanto, a expansão do campo da política institucional ocorrido durante a crise política, uma vez reconstituída uma conjuntura ordinária, confunde-se com a expansão do MAS. Com efeito, o período da crise política de 2000 a 2005 possibilitou a participação de atores indígenas no campo, por meio da eleição de Evo Morales ao governo central e com a realização da Assembleia Constituinte. Nessa, ainda que para serem eleitos, a maioria dos representantes de setores indígenas tenham sido incluídos nas listas do MAS, nem todos representavam o projeto político do qual havia nascido o partido. Ao mesmo tempo, o fato da crise política ter perdurado mesmo depois da eleição de Evo Morales, possibilitava uma maior incidência das diferentes organizações indígenas no campo da política institucional.

Com a superação da crise, as novas fronteiras do campo redefiniram a participação desses atores e, as diferenças aparecem com mais destaque que os processos de negociação. Contudo, uma das consequências da crise política foi o fortalecimento do MAS em todas as regiões do país; fato que teve consequências importantes para o avanço das AIOCs nos onze municípios atualmente em conversão e para a criação de novas autonomias indígena originário camponesas.

Nas eleições municipais de 2010, o MAS ganhou em 68\% municípios bolivianos $^{233}$. Entre 2004 e 2010, os governos locais administrados por representantes do partido passaram de 100 a 231. O MAS elegeu igualmente os alcaldes de nove dos onze municípios em conversão à autonomia indígena, perdendo apenas nos municípios das Terras Baixas, Charagua e Huacaya.

A criação de governos autônomos indígenas além de diminuir a capacidade de incidência do governo central em regiões do país, têm igualmente uma influência

\footnotetext{
${ }^{233} \mathrm{http}: / /$ www.lostiempos.com/diario/actualidad/politica/20100516/mas-gano-en-231alcaldias 70869 130830.html, consultado em 15/05/2014.
} 
potencialmente negativa para atuação e de expansão do MAS, pois, como explicam Do Alto e Stefanoni, "a conquista de um governo departamental ou municipal pode ser lida como a obtenção de uma base material a partir da qual consolidar a hegemonia do partido, mediante a redistribuição de empregos” (2010: 333, tradução minha).

Apresento a seguir o estudo de caso do município de Charagua. A análise visa explicar em que medida esses três momentos de expansão estatal e as disputas em torno da autonomia indígena em nível nacional podem influenciar na construção atual de um projeto autonômico indígena.

\subsection{A construção da autonomia indígena originário camponesa pelos guaranis de Charagua}

Apesar de todas as disputas que ocorrem nacionalmente, a autonomia indígena originário camponesa está sendo construída atualmente em diferentes municípios e territórios indígenas da Bolívia. Aqui apresento o caso do município de Charagua. Ainda que essa experiência não possa ser generalizada, ela indica potenciais consequências, a nível local, do processo político que apresentei ao longo deste trabalho.

A análise proposta é baseada, sobretudo, no ponto de vista de atores que participam do processo autonômico, meus principais interlocutores durante o trabalho de campo em Charagua.

Localizado no sul do departamento de Santa Cruz, Charagua é o maior município do país, em extensão territorial, com mais de 74 mil quilômetros quadrados. Dentro do município de Charagua existem atualmente quatro capitanias guaranis: Bajo Isoso, Alto Isoso, Charagua Norte e Parapitiguasu. Cada capitania é formada por 
dezenas de comunidades indígenas. Além das quatro capitanias, existem no município de Charagua dois centros urbanos: Charagua Pueblo e Charagua Estación, aonde vivem guaranis; migrantes do Altiplano, principalmente dedicados ao comércio; e "brancos e mestiços"234. Além dos guaranis e dos citadinos, outro grupo social importante em Charagua são os menonitas, que criaram colônias, dedicadas principalmente à criação de gado, bastante autônomas na região ${ }^{235}$. Existem igualmente dentro do município de Charagua dois parques nacionais: Otuquis e Kaa Iya del Gran Chaco.

No século XIX, o Estado republicano iniciou o processo de despojo do território da população guarani para garantir a expansão de fazendas para a criação de gado. Expulsos de suas terras, muitos guaranis foram viver em missões jesuítas e outros foram trabalhar, em um regime análogo ao trabalho escravo, para os fazendeiros.

Como apresentei no capítulo 1, diferente do que ocorrera nas Terras Altas, o Oriente boliviano sofreu uma "reforma agrária ao contrário". O resultado para a província da Cordillera, onde fica localizada Charagua, é apontado por Albó: “das 78 comunidades livres de toda a província Cordillera, 35 (19 em Charagua, todas em Isoso) tinham menos de um hectare cultivável por habitante e somente sete (todas elas no piedemonte de Charagua [área de transição entre a faixa subandina e a planície do Chaco]) superam os sete hectares por habitante" (2012b: 47, tradução minha). O desenvolvimento da agronomia do departamento de Santa Cruz gerou a criação de “grandes propriedades [destinadas à pecuária] com uma incidência muito significativa

\footnotetext{
${ }^{234}$ Como me explicaram, apesar de terem duas fazendas e casas no município de Charagua, muitos fazendeiros vivem em Santa Cruz. Contudo, este fato não implica que deixem de ter influência na política local.

235 "Como outros anabatistas, como os amish (de origem suíça), os menonitas desenvolveram uma cultura própria e tradicionalista, marcada pela sua interpretação cristã pacífica e sua vida simples, principalmente rural, que os afasta de outras formas mais modernas e ,mundanas ${ }^{\text {ec }}$...] Em 1957, chegaram à Bolívia junto com outros grupos menores que se assentaram em outros países" (Albó, 2012b: 75, tradução minha).
} 
sobretudo no sul do município de Charagua", explica o autor (ibid.: 48, tradução minha).

Diferente do que ocorrera no Altiplano e nos Vales, o "Estado de 52" não articulou a população camponesa indígena das Terras Baixas em sindicatos. Foiapenas no período de transição de regime, no final da década de 1970 e início da seguinte, que os povos indígenas das Terras Baixas começaram a articular-se regionalmente. Neste processo, o então mburuvicha guasu de Isoso, Bonifacio Barrientos, foi um ator fundamental e, por isso, é considerado o fundador da Cidob.

A articulação guarani se deu assim em diferentes níveis, partindo de níveis macros em direção aos locais. Dessa forma, a organização multiétnica regional promovida por Bonifacio Barrientos facilitou a organização interna do povo guarani que, cinco anos após a fundação da Cidob, criou a Asamblea del Pueblo Guaraní (APG), em 1987. Os cem anos decorridos entre o massacre em Kuruyuki de keriembas (guerreiros) guaranis pelo exército boliviano, em 1892, e o surgimento da APG, em 1987, são interpretados por representantes da organização como um "período de silêncio", que por vezes é apresentado como um "período de reconstituição local”.

A formação da APG é entendida como o início do processo de reconstituição territorial dos guaranis, pois, estimulou a organização das capitanias zonais. Estas funcionam de forma bastante autônoma - refletindo a forma de organização históricamente descentralizada do povo guarani - e a APG aparece como uma instância de coordenação.

No caso de Isoso, a capitania já estava conformada, pois havia sobrevivido ao processo de desorganização supracomunal, resultado das diferentes influências externas. As demais comunidades guaranis do município de Charagua foram "reorganizadas" 
regionalmente, como resultado direto da criação da APG, que levou à formação das capitanias de Parapitiguasu e Charagua Norte, em 1996.

Cada capitania tem sua autoridade máxima, mburuvicha guasu (capitães grandes ou primeiros capitães), e seu diretório, responsável por temas como educação, saúde, terra e território etc. ${ }^{236}$ As capitanias são formadas pelas comunidades guaranis, que elegem mburuvichas locais.

As reformas políticas da década de 1990 tiveram grande impacto na organização da população guarani de Charagua. Com a possibilidade aberta pela Lei Inra para a titulação coletiva de territórios indígenas, por meio das "Terras Comunitárias de Origem" (TCOs). Foram então postuladas três demandas de TCOs guaranis na região de Charagua: Isoso, Parapitiguasu e Charagua Norte.

As Terras Comunitárias de Origem, conquista da Cidob, abriram a possibilidade do reconhecimento estatal da luta que travavam os guaranis em defesa do seu território. Em diferentes regiões, o reconhecimento da posse da terra por meios das TCOs é visto como uma possibilidade de avançar na libertação de "comunidades cativas". Ao reconhecer aos indígenas seu direito sobre parte do território boliviano, abre-se, para parte da população guarani, a possibilidade de reprodução da vida longe das fazendas que empregam um sistema de trabalho análogo à escravidão. Esse argumento é corroborado pela explicação de uma moradora de Puente Viejo, comunidade guarani próxima à Camiri, que contava que nascera no norte argentino, para onde sua mãe havia fugido em função da "escravidão". Há alguns anos ela havia ouvido que havia acabado a "escravidão", e ela foi morar na Bolívia, em uma TCO. Contudo, dizia, "isso ainda não acabou, aqui pertinho ainda tem”.

\footnotetext{
${ }^{236}$ No caso da Capitania de Charagua Norte, por exemplo, esse diretório é formado por oito pessoas: primeira capitã (mburuvicha guasu); segundo capitão; responsável de terra e território; responsável de gênero; responsável de produção; responsável de saúde; responsável de educação e responsável de autonomia (Entrevista com a primeira capitã, Ruth Yarigua realizada em Charagua, novembro de 2013).
} 
Assim, essa história de "escravidão" continua muito presente no relato dos guaranis, como referência ao passado, e a partir da denúncia da manutenção de comunidades guaranis cativas, ainda hoje, em regiões da Bolívia. Talvez, por essa razão, a autonomia indígena seja apresentada repetidamente pelos guaranis como o caminho da construção da liberdade. "O tema da autonomia não é de agora. O povo guarani sempre buscou a liberdade", explica uma autoridade Asamblea del Pueblo Guaraní (APG). Dessa forma, em muitos discursos, a autonomia aparece como uma demanda dos "nossos avós".

Ainda no caso das comunidades que mantiveram formas internas de organização autônomas, tratava-se de uma autonomia limitada, como explica Carlos Sánchez, da capitania Charagua Norte:

Havia alguns indícios [de autonomia de facto] mas na sua totalidade, ainda não. Porque a organização sempre estava sujeita a alguém, que não era parte da vida organizativa dos povos originário. Então sempre havia coisas que dependiam de outras pessoas. Neste caso, quando queria tomar decisões sobre algo, o governo em alguma comunidade, a comunidade não podia decidir, bom, queremos tal coisa, quando falamos do recurso do POA [Plano Operativo Anual] municipal, sempre consultavam as prefeituras se se podia ou não ${ }^{237}$.

Assim como alguns atores percebem a criação de municípios rurais nas Terras Altas como uma possibilidade de acesso ao poder local por parte da população indígena; no caso de Charagua, a criação das TCOs é entendida como um primeiro passo na construção de uma autonomia local, através dos Planos de Gestão Territorial, como explica Marcelo Alberto Quelca, que apoiou como assessor o processo autonômico de Charagua $^{238}$. Puerta e Arandia corroboram a afirmação de Quelca ao apontarem que

\footnotetext{
${ }^{237}$ Entrevista realizada em Charagua, novembro de 2013.

${ }^{238}$ Entrevista realizada em Charagua, junho de 2013.
} 
esses planos, principalmente no caso de Charagua Norte e Parapitiguasu, potencializaram a capacidade da organização local de negociar com outros atores, como petroleiras e o governo, e, igualmente, "fortaleceram suas reflexões e propostas a respeito da autonomia indígena" (2010: 5, tradução minha).

Contudo, um limite importante da Lei Inra, que criaria as TCOs, foi o reconhecimento da posse de terceiros dentro do "território ancestral guarani" $" 239$. Como explica Albó:

A chamada Lei Inra pretendia atender, entre outras, duas situações difíceis de conjugar dentro do enfoque neoliberal do governo, ambas muito presentes no Chaco. Por uma parte, dar segurança jurídica às empresas agropecuárias produtivas e lhes facilitar o acesso ao mercado de terras e, por outra, proteger os pequenos produtores e indígenas, inclusive considerando suas pequenas propriedades inalienáveis.

Se as TCOs foram uma importante conquista para os guaranis, elas não atendiam às necessidades da população indígena que continuava submetida ao governo municipal. Na década de 1990, a promulgação da Lei de Participação Popular (LPP) abriu um novo espaço pela luta do poder local. Assim, paralelamente à luta pela consolidação de suas TCOs, as capitanias de Charagua decidiram disputar espaços dentro do conselho municipal e a própria prefeitura.

Com a LPP, houve um fortalecimento do município, que passou a receber mais recursos. Entre 1994 e 2006, esses recursos aumentaram de 600 mil bolivianos a um pouco mais de oito milhões de bolivianos (Albó, 2012b: 115), tornando o governo local um espaço fundamental de disputa.

Nas primeiras eleições realizadas após a LPP, três dos seis representantes eleitos para o município eram guaranis: dois pela aliança entre a APG e o partido Movimiento

\footnotetext{
${ }^{239} \mathrm{O}$ mapa presente no anexo 5 mostra claramente essa fragmentação do território guarani.
} 
Bolivia Libre (MBL) e um representante de Isoso, eleito pelo MNR (ibid.: 110) ${ }^{240}$. O prefeito foi escolhido através de um acordo entre os representantes do MBL e da ADN, partido de Hugo Bánzer ${ }^{241}$. Assumiu então como prefeito, Luis Saucedo, o único não guarani eleito pela aliança entre o MBL e a APG.

Após o relativo sucesso eleitoral da organização guarani nesta primeira eleição, nas seguintes apenas um de seus candidatos foi eleito, uma vez mais, com o MBL. O antigo prefeito karai $^{242}$, que participara da aliança entre o MBL e a APG, mudou de partido, agora ele representava o MIR, um dos principais partidos da "democracia pactuada". E, uma vez mais, através da sigla do MNR, os guaranis de Isoso elegeram um representante ao conselho municipal.

Em 2004, como apresentado anteriormente, o governo de Carlos Mesa acabou com o monopólio dos partidos políticos, permitindo a participação de "agrupações de cidadãos" nas eleições. Com essa nova possibilidade, a organização guarani em Charagua, com a sigla "APG Charagua Norte", elegeu três representantes nas eleições municipais daquele ano e, com o apoio do MAS, Cláudio López, originário de Parapitiguasu, assumiu como o primeiro prefeito guarani do município.

Durante as eleições, o MAS lançou como candidato um guarani de Isoso. Essa decisão do MAS parece indicar que a estratégia do partido no município não era fortalecer a organização indígena, APG, mas ocupar os espaços possíveis dos "partidos tradicionais", dado que os candidatos de Isoso até então concorriam às eleições como representantes destes partidos, com independência em relação à organização. Contudo, Ruth Yarigua aponta a importância da aliança, naquelas eleições, entre a APG e o que

\footnotetext{
${ }^{240}$ Como apresentei no capítulo 1, o MBL havia igualmente consolidado alianças nacionais com a Cidob. ${ }^{241}$ Nessas eleições, foram eleitos três candidatos do MBL (APG), 2 do MNR e 1 da ADN.

${ }^{242}$ Branco.
} 
chama de "classes baixas" do centro urbano, como professores e o setor de transportes, já que os "pecuaristas e o comité cívico nunca iriam apoiar"243.

Em 2010, depois de aprovada a autonomia indígena, o Tribunal Superior Eleitoral decidiu que deveria haver eleições para alcaldes nos onze municípios que estavam em conversão à autonomia indígena originário camponesa. Os prefeitos deveriam administrar os municípios temporariamente, até a aprovação estatutos autonômicos em referendo. Ao mesmo tempo, como mencionei anteriormente, essas eleições representavam uma oportunidade para o MAS expandir sua base e consolidarse como força política hegemônica. E, no caso de Charagua, a estratégia eleitoral adotada pelo partido o afastou da organização guarani.

O MAS havia se fortalecido no município nos anos anteriores, muito em função da aliança com a APG. Em 2005, os moradores de Charagua não haviam apoiado majoritariamente a candidatura de Evo Morales, contudo, a partir de 2008 esse cenário muda. Diferente do que ocorria na maioria dos municípios de Santa Cruz, em Charagua, o MAS ganhou no referendo revogatório do mandato presidencial de 2008, no referendo sobre a nova Constituição, em 2009, e nas eleições presidenciais realizadas no mesmo ano. A APG apoiou o MAS em todas essas consultas. No entanto, em 2010, a organização e o partido lançaram candidatos diferentes ao governo municipal. Nessa eleição concorreram à prefeitura, pela primeira vez, três candidatos guaranis: pela APG, pelo MAS e pelos Verdes, sigla criada pelo governo departamental de Santa Cruz $^{244}$. Essas escolhas indicavam o reconhecimento da legitimidade dos guaranis no município após o referendo em que fora a provada a autonomia indígena, em dezembro de 2009. Os candidatos do MAS e dos Verdes eram de Isoso, distrito indígena mais populoso de

\footnotetext{
${ }^{243}$ Entrevista realizada em Charagua, novembro de 2013.

${ }^{244}$ Verdes "era o novo nome que, em Santa Cruz tomaram os herdeiros políticos do antigo partido ADN, depois reciclado como Podemos e, mais recentemente, como PPB-CN” (Albó, 2012b: 128, tradução minha).
} 
Charagua, e, tradicionalmente mais afastado da APG. Os partidos políticos pareceram então utilizar-se da conhecida divisão entre avas (guaranis de Charagua Norte e Parapitiguasu) e isoseños (chanés isoseños guaranizados, segundo Albó, 2012b), para disputar o controle do poder local ${ }^{245}$. Finalmente, foi eleito Domingo Merida, do Verdes, com 39\% dos votos (ibid.).

Os resultados dessas eleições tiveram grande importância na construção do processo autonômico indígena de Charagua, pois, ao mesmo tempo em que se construía a autonomia indígena, por meio da Assembleia Autonômica de Charagua, responsável por redigir o novo estatuto, o governo municipal "transitório" era controlado por um grupo político representante das elites políticas do departamento de Santa Cruz, que se posicionara contra a possibilidade de construção de autonomias indígenas na Bolívia.

É interessante notar que nas eleições de 2010, além dos três candidatos guaranis, a APG apresentou igualmente dois candidatos karai. Este era um indício da aproximação necessária com os setores urbanos não indígenas, que se refletiria na construção do estatuto autonômico indígena a partir daquele ano. Este é um tema central da construção da autonomia indígena pela via municipal: a inclusão no projeto autonômico de representantes das minorias que vivem no município.

No referendo de 2009, a conversão do município de Charagua à autonomia indígena originário camponesa foi aprovada por $56 \%$ de sua população. Os resultados por distritos foram os seguintes:

\footnotetext{
${ }^{245} \mathrm{O}$ processo de mestiçagem entre guaranis e chanés (povos que estavam sedentarizados nessa região antes da chegada dos guaranis) é antigo, e, ainda que todos se reconheçam atualmente como guaranis, essas diferenças aparecem em alguns discursos. Mas esta diferença me parece, em grande parte, um resultado da política das autoridades locais, já que o mburuvicha guasu que comandou Isoso (Bajo e Norte) por muitas décadas era um importante aliado das elites políticas regionais.
} 
Resultado do Referendo sobre a autonomia em Charagua

\begin{tabular}{|l|l|l|l|l|l|l|l|l|}
\hline Distrito & "sim" & $\%$ & "não" & $\%$ & $\begin{array}{l}\text { Total } \\
\text { válidos }\end{array}$ & Brancos & Nulos & Total \\
\hline $\begin{array}{l}\text { Charagua } \\
\text { Centro }\end{array}$ & 938 & 38 & 1.577 & 62 & 2.560 & 87 & 98 & 2.742 \\
\hline $\begin{array}{l}\text { Charagua } \\
\text { Norte }\end{array}$ & 1.044 & 84 & 196 & 16 & 1.240 & 65 & 37 & 1.342 \\
\hline Parapitiguasu & 659 & 72 & 260 & 28 & 919 & 43 & 20 & 982 \\
\hline Alto Isoso & 531 & 52 & 260 & 28 & 1.024 & 90 & 43 & 1.157 \\
\hline Bajo Isoso & 600 & 56 & 515 & 46 & 1.115 & 69 & 28 & 1.212 \\
\hline Total & 3.817 & 56 & 3.041 & 44 & 6.858 & 354 & 223 & 7.435 \\
\hline
\end{tabular}

Fonte: Puerta e Arandia (2010)

O processo de conversão à AIOC de Charagua foi apoiado pelas quatro capitanias. As diferenças entre a alta aprovação no referendo em Parapitiguasu e Charagua Norte e a vitória por uma pequena margem nas capitanias de Isoso é explicada pelo maior engajamento na campanha do referendo pelas autoridades das duas primeiras em relação às outras e a histórica proximidade da autoridade local com as elites políticas departamentais.

Depois da aprovação da conversão à autonomia indígena originário camponesa, o passo seguinte foi a formação da Assembleia Autonômica de Charagua. Essa deveria ser formada por 45 representantes guaranis das quatro capitanias, eleitos em assembleias zonais, e 14 representantes da "população minoritária intercultural”, sete para cada centro urbano $^{246}$. No entanto, havia uma forte oposição de parte do setor urbano, que se

\footnotetext{
${ }^{246}$ Segundo as regras definidas para a eleição dos representantes guaranis, "o qórum requerido para a realização da Assembleia Zonal para a eleição se realizará com a presença da maioria (50\% mais um) dos
} 
recusava a participar da construção do processo autonômico indígena. Depois de alguma negociação, representantes da Estación, formada principalmente por migrantes guaranis e do Altiplano, foram eleitos para formar a Assembleia Autonômica ao lado daqueles representantes eleitos nas capitanias. Charagua Pueblo, contudo, não participou do processo.

Várias tentativas de diálogo com os setores urbanos foram relatadas, e, durante o funcionamento da Assembleia Autonômica, propagandas no rádio e na televisão convidavam a população urbana a participar da construção do estatuto. Em uma dessas convocatórias, o presidente da Assembleia, René Gómez, dizia: “o estatuto que estamos escrevendo não é somente para os guaranis, mas para todos que vivemos no município de Charagua”. "Agora a lucha é com papel e lápis. E isso se reflete aqui. Já não é fazer campanha suja por aqui, utilizando recursos, comprando dirigentes, isso já não. Deveriam se apresentar aqui [...] propondo propostas, debatendo frente a frente, par a par", convocava Ronald Andrés Caraica, representante de Charagua Norte. "Não tenhamos ciúmes, formemos parte, venhamos, sejamos parte desse processo de construção. Porque aqui se está construindo um sistema de governo participativo, comunitário e, ademais, representativo", afirmava Marco Antonio Casiano, representante de Charagua Estación. "Autonomia com interculturalidade e pluralismo", era o lema da propaganda.

Em Charagua, além das dinâmicas locais, o debate da autonomia refletia a polarização política nacional. A autonomia indígena aparecia como um projeto apoiado

delegados e das delegadas do total das comunidades membro de cada capitania zonal. A assembleia zonal para a eleição será conduzida pela mesa de presídium e seus membros são eleitos e eleitas pela assembleia zonal mediante aclamação, consenso ou na forma que a assembleia determine" (Procedimiento de elección de asambleístas indígenas membros del órgano deliberativo autonómico guarani em Charagua, tradução minha). 
pelo MAS. Segundo o presidente de uma organização territorial de base do centro urbano, migrante do Altiplano e representante do MAS, ele havia apoiado a autonomia indígena e, por esta razão, havia recebido muitas ameaças. As tentativas de intimidação e suborno por parte da oposição são apontadas igualmente por diferentes atores que participaram do processo de construção autonômica em Charagua.

Por outro lado, as elites locais apareceram alinhadas com a política departamental; "os que não queriam a autonomia indígena eram aqueles que estavam com as autonomias departamentais”, explica Carlos Sánchez. Corroborando a afirmação de Sánchez, Belarmino Solano afirma que "o tema da construção da autonomia não foi fácil. Então sempre havia os partidos políticos. Nesse caso, a direita, através dos verdes. Nesse caso eles desanimavam, diziam que era um processo ilegítimo, ilegal e que não tinha toda a sustentação jurídica"247.

Dentro desse contexto de disputas, a participação do presidente Evo Morales, assim como a presença dos sucessivos ministros de autonomias em eventos em Charagua, como na posse da Assembleia Autonômica, foi importante para afirmar a legitimidade do processo de construção da autonomia indígena guarani e angariar o apoio das bases urbanas do partido.

A assembleia se reunia no Centro Arakuaarenda, que havia sido criado na década de 1980, com apoio da paróquia local, para a formação de líderes guaranis, com um enfoque na educação popular ${ }^{248}$. Igualmente importante no processo de conversão à

\footnotetext{
${ }^{247}$ As disputas nacionais aparecem refletidas em diferentes âmbitos em Charagua. Por exemplo, uma nova escola construída com o programa "Bolivia hace, Evo Cumple" em Charagua Pueblo encontrava-se abandonada. Em junho de 2013, explicaram-me que o governo municipal impedia que a obra fosse concluída (embora já estivesse praticamente pronta) porque não havia interesse político em inaugurá-la. Naquele momento, o governo departamental estava financiando a pavimentação das ruas centrais de Charagua Pueblo.

${ }^{248} \mathrm{O}$ objetivo do centro de fortalecer a organização social e política e promover o desenvolvimento econômico. Fonte: http://arakuaarenda.org/la-fundacion/, consultado em 22/05/2014. Como explica Marcelo Alberto Quelca, muitos dirigentes da província Cordillera participaram dos programas do centro,
} 
autonomia indígena do município foi o apoio da ONG Cipca, criada por jesuítas e que, desde 1976, trabalha com a população guarani de Charagua.

Em diferentes momentos, os representantes da assembleia percorreram as diferentes comunidades guaranis para recolher propostas e apresentar os rascunhos do estatuto. As dificuldades apresentadas pelos representantes foram muitas. Primeiro era preciso apropriar-se de todos os marcos jurídicos do Estado boliviano, dentro dos quais devia ser construído o estatuto. Ao mesmo tempo, apesar destes marcos, tratava-se de construir algo novo, já que eles são uns dos pioneiros na construção da AIOC. Nesse processo, Belarmino Solano explica que o único ponto de partida que tinham eram os estatutos das zonas (capitanias) e que, destes, tomaram muitas coisas para a elaboração do estatuto, como os valores, os princípios e as formas de trabalho.

Como aponto a seguir, são várias as motivações apresentadas pelos autores para a conversão do município de Charagua em uma autonomia indígena originária guarani. Uma das principais seria acabar com os partido políticos ${ }^{249}$. O posicionamento crítico à forma de organização partidária reflete a má avaliação que os atores fazem das diferentes alianças feitas entre representantes guaranis e os partidos tradicionais. Ruth Yarigua explica este processo:

Mas através da organização fizemos essa aliança com outras capitanias. Ir preparando nossa proposta de como vamos influenciar dentro no governo municipal. Mas, bom, como não havia nossa própria legenda, tivemos que aceder por outros partidos tradicionais, fazendo alianças, não? Mas sempre respeitando nosso princípio como APG, não? Então, dessa forma, conseguimos alguns espaços para hermanos guaranis dentro da prefeitura. A partir de aí, então, mais ou menos funcionaram alguns projetos

dentre eles, Ruth Yarigua, atual primeira capitã de Charagua Norte e uma das principais apoiadoras do processo de construção da AIOC. Entrevista realizada em Charagua, junho de 2013.

${ }^{249}$ Marco Antonio Casiano, representante de Charagua Estación na Assembleia Autonômica, explica que, no caso das zonas urbanas do município, o estatuto deixou aberta a possibilidade para a atuação dos partidos políticos, que ficaria condicionada à decisão dos moradores de Charagua Pueblo e Estación. Entrevista realizada em Charagua, novembro de 2013. 
nas comunidades. Mas sempre se via, digamos, eles estavam discriminados dentro da sociedade, porque eram guaranis e os outros $\mathrm{karai}^{250}$.

Carlos Bazan, que foi eleito para o conselho municipal pela APG, em 2004, e que mais tarde participaria da redação do estatuto em Charagua, explica que o modelo municipal nunca favoreceu os guaranis, que foram usados como escada para os partido políticos $^{251}$. A constatação do insucesso das alianças com os partidos políticos, que são descritos como prejudiciais ao povo guarani, apareceu repetidas vezes durante a apresentação dos estatutos em comunidades guaranis. Em um destes eventos, um membro da Assembleia Autonômica dizia: "vamos pisotear os partidos políticos, vamos enterrar, porque já nos fizeram brigar muito", e explicava que entre irmãos estavam brigando por causa dos partidos, "porque um é do verde, o outro do azul, o outro do amarelo",252. Naquele mesmo evento, outro representante guarani afirmava que "se alguém diz não [à autonomia] é porque quer seguir sendo manipulado. Eu não quero mais ser manipulado". O representante apontava da seguinte forma a influência dos partidos políticos na divisão da organização local:

É isso que não queremos que haja com essa autonomia. Há capitães ou autoridades paralelos a eles. E por quê? Estávamos falando dos partidos políticos e é por isso. Porque esses partidos políticos estão metidos dentro da nossa organização, ou dentro de nós como povo civil. Estão colocando dinheiro.

Belarmino Solano, vice-presidente da Assembleia Autonômica de Charagua, explica que o sistema municipal "foi uma imposição pelo tema da colonização. Isso não

\footnotetext{
${ }^{250}$ Entrevista realizada em Charagua, novembro de 2013.

${ }^{251}$ Entrevista realizada em La Paz, novembro de 2012.

${ }^{252} \mathrm{Na}$ Bolívia, cada partido é associado a uma cor.
} 
responde à nossa realidade. Não responde ao nosso ñande reko, nosso modo de ser". Igualmente, falando sobre as motivações da autonomia indígena, Solano explica:

[Estamos] cansados de muito atropelamento e abuso que nos faziam os partidos tradicionais, não? Então o povo guarani pode viver sem os partidos políticos e pode viver melhor sem que ninguém esteja por cima do outro. Então são essas as motivações necessárias no sentido de dizer basta aos que usaram o povo guarani ${ }^{253}$.

Outra motivação que os atores apresentam para a construção da autonomia indígena é a possibilidade de controlar os recursos locais, permitindo um maior “desenvolvimento".

Ainda que tenham sua própria terra titulada coletivamente, a venda da sua mãode-obra em fazendas da região continua sendo importante para o sustento econômico das famílias de boa parte da população guarani rural de Charagua. A AIOC é então entendida por atores que participam do processo de sua construção no município como uma possibilidade de "poder melhorar a situação econômica do nosso povo e melhorar as condições de vida de nosso povo, porque temos bastantes recursos em nosso município, e seguíamos como antes... Queríamos mudar”, explica Carlos Sánchez, que participou, como representante da capitania Charagua Norte, dos primeiros momentos de construção do processo autonômico em Charagua ${ }^{254}$. Igualmente, Sánchez explica que o controle dos recursos naturais é uma importante motivação para autonomia "porque seguimos mendigando frente ao governo central e tendo recursos aqui". Sánchez faz referência especificamente à exploração de hidrocarbonetos nos territórios das capitanias de Charagua e ao potencial para criação de gado. "Sentados em cima do

\footnotetext{
${ }^{253}$ Entrevista realizada em Charagua, novembro de 2013.

${ }^{254}$ Entrevista realizada em Charagua, novembro de 2013.
} 
tesouro, somos os mais pobres", afirma do vice-presidente da Assembleia Autonômica de Charagua, Belarmino Solano ${ }^{255}$.

A possibilidade de melhorar as condições de vida dos habitantes guaranis do município era repetidamente apresentada como uma das vantagens da autonomia indígena durante os encontros de "socialização" do estatuto autonômico que acompanhei. Com a autonomia, e a possibilidade de controlar o desenvolvimento econômico local, já não seria mais necessário ir trabalhar em fazendas, argumentava um membro da Assembleia Autonômica de Charagua, ao explicar o novo estatuto em uma comunidade de Isoso.

No entanto, o objetivo da autonomia indígena é muito mais amplo. Como explica Solano, a principal preocupação dos representantes da Assembleia teria sido a estrutura de governo, "estruturá-lo bem a favor das bases". A preocupação em "resgatar os valores" guaranis aparece na fala de Carlos Sánchez quando opina sobre as "lógicas" da autonomia indígena, "porque já estamos perdendo o idioma, já estamos perdendo de repente o „compartimento ${ }^{\text {ee”, }}$ como resultado deste processo, argumenta, “ao fim e ao cabo o povo guarani vai terminar sendo apenas nome. Assim eram os povos indígenas, assim eram os guaranis, vão dizer. Fica apenas em nome, apenas nos estudos, quando podíamos fortalecer uma autonomia entre todos".

A importância de resgatar os valores guaranis a partir da autonomia reapareceu diversas vezes durante a apresentação do estatuto nas comunidades. Em um desses eventos, um representante da Assembleia dizia:

Esta autonomia está em nossas mãos para que possamos seguir nos fortalecendo mais, poder conseguir o queremos e viver tal como queremos viver, com nossa família. Ou para que nossa família que quer possa viver melhor do que vivemos agora. Não se pode recuperar tudo. Mas vai se recuperar, ou não perder mais, podemos manter tal como está

${ }^{255}$ Entrevista realizada em Charagua, novembro de 2013. 
agora, com essa autonomia. Porque se essa autonomia não vai adiante, seguramente vai se perdendo mais, nossa cultura, nossa tradição.

As diferentes "lógicas" da autonomia de que fala Carlos Sánchez ficam evidentes no discurso do Segundo Capitão Grande de Bajo Isoso:

Tudo o que o estatuto contém é como uma história, de como vivíamos antes e isso que queremos recuperar, porque falamos de valores, de cultura, então, tudo isso é o que queremos recuperar. Porque antes os guaranis compartilhavam tudo o que tinham, mas agora já pouco. Outra coisa era na questão do trabalho. Então quando um não podia fazer ou avançar em seu trabalho, dizia ,quero que me ajudem“. Então o dono do trabalho mandava preparar chicha, preparar o alimento e [outro] trabalhava meio dia, umas quatro, cinco horas. Outro vinha e comia seu almoço aí, depois tomava a sua chicha, fazia sua pequena festa. Isso agora não existe, e isso que queremos recuperar [...] como eu te dizia, ninguém mais quer falar guarani. Mas agora o Estado reconhece nosso idioma e é uma obrigação do karai $^{256}$ que saiba guarani, quéchua ou aymara. Isso também é o que nos motiva a fazer a autonomia indígena. Como dizia há pouco, isso nos abre a porta para aceder a muitos outros âmbitos, digamos, para poder seguir melhorando [...] porque agora, nesse município que estamos, é como se estivéssemos fechados em um quarto, com a porta fechada e nem a janela aberta. Tudo isso é o que nos motiva porque sabemos que com a autonomia indígena vamos melhorar a educação, a saúde, a produção. Por quê? Porque vai haver mais recursos econômicos, sobretudo, do governo diretamente à autonomia indígena ${ }^{257}$.

As dificuldades encontradas pelos promotores da autonomia guarani em Charagua ao longo dos últimos anos foram diversas. Além da oposição da elite urbana, outra dificuldade apontada consistia na necessidade da apropriação das regras e leis estatais pelos representantes guaranis, que deveriam, ao mesmo tempo, adaptar as suas normas a este marco jurídico. Se, através da autonomia indígena, o Estado reconhece as

\footnotetext{
${ }^{256}$ Diz-se karai para os "não indígenas".

${ }^{257}$ Entrevista realizada na comunidade de Aguarati, Bajo Isoso, junho de 2013.
} 
formas de organizações locais, estas, ao serem reconhecidas e reconhecerem o Estado, devem adaptar-se a ele, mas, ao mesmo tempo, romper com algumas de suas lógicas.

A expansão do Estado boliviano a partir da criação de municípios rurais deu-se com base em uma estrutura colonial, ou seja, sem respeitar as fronteiras e formas de organização social e política de parte da sua população. Romper com essas lógicas é um dos desafios da autonomia indígena de Charagua, assim como a necessidade de mudar o que um ator chamou de "estrutura mental", reflexo da colonização. Esse tipo de estrutura implica na desvalorização de saberes distintos daqueles valorizados dentro do campo da política institucional. Esse fato foi apresentado por diferentes atores entrevistados que explicavam que havia, e ainda há, a ideia de que os guaranis não são capazes de ocupar posições de governo porque não teriam estudo ou não conheceriam as regras. 


\section{Considerações finais}

A criação do Estado Plurinacional Boliviano e o fortalecimento de atores indígenas na política do país é resultado de décadas de lutas. No momento de transição entre os séculos XX e XXI, tais lutas culminaram em uma forte mobilização multisetorial contestadora da ordem política vigente. Este trabalho mostrou como as fronteiras do campo da política institucional foram rompidas com essa mobilização.

A forma que adquiriu a transição política, através da consolidação de um partido político com um discurso alternativo, foi resultado da estratégia adotada na década de 1990, por parte dos indígenas e camponeses, de participação no campo da política institucional com um "instrumento político” próprio. Esse não era um fato inédito, pois, partidos que reivindicavam uma identidade camponesa e indígena já haviam sido criados na década de 1970. Contudo, nos anos 2000, um novo contexto nacional possibilitou o fortalecimento desta proposta. Como explica Pedro Portugal, intelectual aymara, "agora o indígena é uma questão aceita, mas nessa época [na década de 1970], falar de um projeto índio, de um projeto político era uma provocação"258.

Apesar da ascensão de representantes dos setores indígenas e camponeses em 2006, a crise política iniciada anos antes não chegou ao fim. Ela adquiriu novas características. A partir daquele ano, os papéis se inverteram: aqueles que haviam sido deslocados do controle do poder político nacional buscavam a desestabilização institucional; enquanto os movimentos sociais, que haviam levado à desestabilização dos governos anteriores, colocavam-se como defensores da nova ordem.

\footnotetext{
${ }^{258}$ Entrevista realizada em La Paz, novembro de 2012.
} 
A estabilização institucional foi alcançada com a vitória de Evo Morales no referendo revogatório de mandato, com as negociações com a oposição sobre as mudanças no texto constitucional, com a reeleição de Morales e García Linera, em 2009, e a vitória do MAS nas eleições legislativas daquele ano.

Com a superação da crise e o retorno à "conjuntura ordinária", as fronteiras do campo foram redefinidas e novos espaços de participação foram criados para os atores indígenas. Contudo, nessa reordenação, o espaço ocupado pelas organizações indígenas e camponesas foi sendo progressivamente disputado por atores que detêm o controle do governo central. Tal fato resultou, como apresentei, não apenas em um crescente distanciamento entre organizações indígenas, por um lado, e camponesas, por outro; como também em uma divisão no interior de algumas organizações.

As análises sobre as causas da crise política apresentadas na revisão da literatura não permitiam ver as importantes diferenças que já existiam dentro do "bloco contestador" durante o período de mobilização social, entre 2000 e 2005. Consequentemente, as disputas que surgiram depois da crise, entre as diferentes organizações e entre estas e o governo do MAS, pareceram surpreendentes. A vantagem do estudo da dinâmica da crise proposto é indicar que estas disputas já estavam presentes e que, se era possível apontar a articulação "bloco contestador" à ordem vigente, como indica parte da literatura, tal fato refletia a capacidade de diferentes setores subalternos indígenas de, apesar de suas divergências, construir alianças em um momento de grave crise política.

No entanto, é possível igualmente afirmar que o novo contexto político favoreceu o fortalecimento de divergências internas nas organizações e a disputa entre elas. Isto se deve a diferentes fatores: em primeiro lugar, Evo Morales é visto pelas bases de muitas organizações como um "hermano" indígena. No caso do Conamaq, essa 
percepção dificulta a capacidade de mobilização da organização de suas bases contra as políticas governamentais, como explica Freitas (2012). Tal fato favorece o fortalecimento de correntes dissidentes dentro das organizações que apoiam o governo central. Em segundo lugar, diferentes políticas governamentais melhoraram as condições de vida de parte importante dos bolivianos, ao mesmo tempo em que disponibilizaram um volume de recursos inédito para os governos locais, possibilitando uma maior expansão do MAS. Finalmente, o governo é acusado por seus opositores dentro das organizações indígenas de favorecer, através de diferentes formas de financiamento, as organizações camponesas e os diretórios paralelos das organizações indígenas que o apoiam.

Como vimos, a redefinição do campo da política institucional veio acompanhada do projeto de criação do Estado Plurinacional, que aponta para o reconhecimento de formas de organizações sociais e políticas já existentes dentro do território boliviano e que se encontravam "clandestinas"259. O objetivo deste trabalho foi então entender como a rearticulação do campo da política institucional influenciou na reestruturação estatal anunciada. Para tanto, parti da análise dos debates sobre as autonomias indígenas.

Nesse contexto de mudanças políticas, a autonomia indígena apareceu como um espaço de disputa entre os atores. A autonomia indígena surgiu no debate constituinte como proposta das organizações indígenas que, não obstante seu apoio ao MAS, tinham uma origem distinta do projeto político do partido, que visava a disputa do controle do Estado. Apesar de diferentes atores e autores perceberem a adesão do MAS ao projeto autonômico da promovido pela APG, a Cidob e o Conamaq, como uma forma de limitar as reivindicações de autonomia departamental, vimos que, durante o processo

\footnotetext{
${ }^{259}$ A percepção de que os indígenas estavam como "clandestinos", ou "quase clandestinos" apareceu em diferentes entrevistas com autoridades indígenas.
} 
constituinte, o apoio dos representantes do partido a esta demanda se deu a partir de negociações e da pressão das organizações indígenas.

Alguns atores envolvidos na produção de análises sobre as autonomias indígenas sugerem que este projeto seria mais adequado aos povos e nações minoritários, pois, aos povos e nações majoritários, quéchuas e aymaras, caberia o controle do Estado e não autonomizar-se deste. De fato, a autonomia indígena, tal como foi aprovada, limita a possibilidade de criação de AIOC para um número importante de atores, ao excluir os centros urbanos e os chamados "interculturais" - a parte do campesinato que, apesar de reivindicar uma identidade indígena, não ocupa atualmente o seu "território ancestral" tal como passou a ser exigido pela Constituição, após a revisão do texto de Oruro. No entanto, oito dos onze municípios atualmente em conversão à AIOC são formados por populações quéchuas e aymaras. Esse fato parece sugerir que atores que são parte de povos majoritários, ao não se reconhecerem na forma de organização da política nacional, podem optar por uma construção local autônoma. Como me contava uma autoridade de um município do Altiplano atualmente em conversão à AIOC, a motivação dos habitantes do município em tornarem-se autônomos era justificada porque "o problema é a política; a direita e a esquerda".

Com efeito, tal como se apresenta o debate sobre as autonomias indígenas na Bolívia, seus principais defensores são aqueles que ocupam atualmente posições periféricas dentro do novo campo político.

A interpretação do processo autonômico de Achacachi, relatada por Felipe Quispe, reflete parte das contradições decorrentes do processo de acomodação dos atores no novo cenário político, após a ascensão do MAS ao governo nacional e sua posterior consolidação como partido hegemônico. 
Como apresentei no capítulo 2, as mobilizações sociais lideradas pela CSUTCB, durante a primeira fase da crise, resultaram na construção de autonomias radicais de facto, a partir da expulsão de autoridades estatais de diferentes municípios do Altiplano de La Paz. Era uma autonomia contra o Estado. Felipe Quispe, antigo secretário geral da CSUTCB que liderou as revoltas no Altiplano aymara entre 2000 e 2003, falando do processo de autonomia radical de facto em Omasuyus, explica que "era como uma gota de óleo caída sobre a pedra, com o sol a mancha vai avançando. Era igualzinho. Creio que hoje já teríamos toda a nação aymara". Contudo, Quispe afirma que este processo foi interrompido com a eleição de Evo Morales, quando teriam voltado o exército, a polícia e os juízes $^{260}$.

Uma das lideranças das revoltas de Achacachi era Eugênio Rojas, que pertencia ao partido criado por Quispe, Movimiento Indio Pachakuti (MIP). Rojas é atualmente presidente do Senado boliviano, representando o MAS. Assim como Rojas, muitos representantes do movimento indígena camponês ocupam atualmente cargos no Legislativo e no Executivo.

A renovada legitimidade adquirida pelo Estado boliviano a partir da participação desses novos atores no campo da política institucional, pode implicar, como demonstra Quispe, em um enfraquecimento de formas de organização autônomas locais. Entretanto, o reconhecimento constitucional das "autonomias indígena originário camponesas" abriu uma nova possibilidade de construção autônoma. Ainda que o reconhecimento estatal da autonomia venha acompanhado da sua limitação, a AIOC, para Quispe, é uma alternativa desejável ${ }^{261}$.

\footnotetext{
${ }^{260}$ Entrevista realizada em La Paz, dezembro de 2013.

${ }^{261}$ Quispe explica que atualmente se discute em Achacachi a conversão do município em AIOC e que havia participado destes debates.
} 
Para além dos debates a nível nacional, a construção das "autonomias indígena originário camponesas" implica em importantes dilemas para as comunidades indígenas. A partir do reconhecimento estatal das formas de organização locais, essas passam a ser moldadas pelo Estado. Se, por um lado, os atores veem a AIOC como uma possibilidade de sustentação de governos locais indígenas, por outro, elas podem representar uma ameaça às formas de organização social e política que sobreviveram e foram se reconstruindo ao longo do tempo de forma relativamente autônoma ao Estado e que garantiram a reprodução das comunidades. Como explicava um representante do Conamaq, o que está é jogo é saber até onde é possível deixar entrar o Estado. Nesse sentido, trata-se de um processo de negociação de limites, tanto da parte Estado às comunidades, como destas à atuação e controle estatal.

A grande diversidade étnica, política, econômica, social e cultural existente na Bolívia representa um grande desafio para aqueles que procuram entender o atual processo político boliviano e dificulta qualquer possibilidade de generalizações a respeito dos diferentes impactos dos processos de expansão estatal vividos no país desde a Revolução Nacional de 1952. Por essa razão, ao longo deste trabalho, procurei apresentar não apenas as diferentes consequências e contradições do processo político estudado, como também suas distintas interpretações.

Outro desafio para esta análise foi o fato de se tratar de um processo político muito recente. Por um lado, já é possível observar muitas indicações a respeito da reorganização do campo da política institucional na Bolívia, que analisei, notadamente, a partir do estudo dos debates em torno da autonomia indígena. Contudo, por outro lado, o processo de reordenação estatal que implica, dentre outras mudanças, no reconhecimento da autonomia indígena, tem um tempo mais longo que aquele das transformações na "conjuntura política". Nesse sentido, tanto representantes do governo 
como das organizações sociais enfatizam que a construção das AIOCs é um processo de longo prazo. Por um lado, diferentes atores argumentam que os estatutos elaborados pelos municípios em conversão à autonomia indígena são um primeiro passo e que, possivelmente, serão alterados com o tempo. Por outro lado, há a ideia de que outros municípios estariam esperando que esses processos se consolidem para decidirem se optarão pela conversão.

A constituição da "Autonomia Guarani Charagua Iyambae" indica a possibilidade aberta pelo novo contexto político boliviano e pela construção do Estado Plurinacional para a reconstrução da lógica estatal a partir de outros saberes e de formas de organização próprias dos diferentes povos e nações indígenas bolivianos. A possibilidade de subversão dessa lógica é indicada pelos valores presentes no estatuto redigido pela maioria guarani: yeyora (liberdade); yaiko kavi (vivir bien); oyea yaiko vae (pluralidade); ivi maraei (terra sem mal); jupigue opaetepe (justiça social); meteiramiño (unidade); yombori (solidariedade); ñomoiru (complementariedade); kiambae (dignidade); tëta (comunidade); yekuaa irü vae Reta ipitepe (identidade); yeupiti päve (equidade). E, igualmente, pelos princípios apontados: teko kavi (vida harmoniosa); motïro (trabalho comunitário e solidário); mbaeyekou toyeporu yemboetereve (que as riquezas naturais sejam utilizadas segundo a necessidade no marco do respeito à natureza); mboroaiu (amor ao próximo); ñemoäta gätu (valentia).

Ao elaborar uma estrutura de governo onde os principais órgãos de decisão são

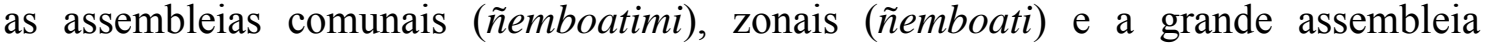
(ñemboati guasu), e, simultaneamente, implantar diferentes formas de controle das bases sobre os representantes eleitos, os guaranis subvertem a lógica política do Estado boliviano. 


\section{Referências Bibliográficas}

ALBO, Xavier. (2007), "Movimientos indígenas desde 1900 hasta la actualidad”, In: Jesús Espasandín López e Pablo Iglesias Turrión (org.), Bolivia en Movimiento: acción colectiva y poder político. Barcelona: El Viejo Topo, pp.67-100.

. (2008), Datos de una encuesta. El perfil de los constituyentes, Tinkazos, 11 (23-24), pp. 49-64.

. (2009), "Movimiento y poder indígena en Bolivia, Ecuador y Perú”, In:

Fernando Calderón (org.), Movimientos socioculturales en América Latina, Villa Balleste: Siglo XXI e PNUD.

. (2012a), Tres Municipios Andinos Camino a la Autonomía Indígena.

Cuadernos CIPCA 78. La Paz: Ministerio de Autonomías/ GIZ/ Cooperación Bolivia Alemania/ CIPCA.

- (2012b), El Chaco Guarani Camino a la Autonomía Indígena.

Cuadernos CIPCA 79. La Paz: Ministerio de Autonomías/ GIZ/ Cooperación Bolivia Alemania/ CIPCA.

ALBÓ, Xavier Albó; Inés Valeria Carrasco. (2008), “Cronología de la Asamblea Constituyente", Tinkazos, 11 (23-24), pp. 101- 128.

ALBÓ, Xavier; Carlos Romero. (2009), Autonomías Indígenas en la realidad boliviana y su nueva Constitución. La Paz: Vicepresidencia del Estado Boliviano, GTZ/PADEP.

AGUILUZ IBARGUEN, Maya. (2006), “Introducción”, In: Maya Aguiluz Ibarguen e Norma de los Ríos Méndez (org.), René Zavaleta Mercado. Ensayos, testimonios y revisiones. Buenos Aires: Miño y Dávila Editores.

ALONSO, Angela. (2009), "As teorias dos movimentos sociais: Um balanço do debate", Lua Nova, (76), pp. 45-86.

ANTEZANA, Luis. (2009), "La crisis como método en René Zavaleta Mercado", Ecuador Debate, 77, pp.107-124.

(1983), "Sistema y proceso Ideológicos en Bolivia (1935-1979)",

In: René Zavaleta (org.), Bolivia Hoy, Siglo XXI, pp. 60-84.

Antreproyecto de Ley Marco de Autonomías y Descentralización, Julho 2009.

ASSIES, Willem; Ton Salman. (2005), "Ethnicity and Politics in Bolivia", Ethnopolitics, 4(3), pp. 269-298. 
BARTH, Fredrik. (1969), "Introduction”, Ethinic Groups and Boundaries, disponível em:http://isites.harvard.edu/fs/docs/icb.topic228815.files/Week 2/Barth\%20Introduct ion\%20Ethnic\%20Groups\%20and\%20Boundaries\%20.pdf.

BARTOLOMÉ, Miguel Alberto. (2006), “As etnogêneses: velhos atores e novos papéis no cenário cultural e político", MANA, 12(1), pp.39-68.

BATAllA, Bonfil. (1987), Mexico Profundo: Una civilización negada, Cidade do México: Grijalbo.

BOCCARA, Guillaume. (2010a), «Cet obscur objet du désir... multiculticulturel (I) : indianité, citoyenneté et nation à leère de la globalisation néolibérale », Nuevo Mundo Mundos Nuevos, disponívell em : http://nuevomundo.revues.org/59975 (acessado em dezembro 2012).

. (2010b), «Cet obscur objet du désir... multiculticulturel (II) : indianité, citoyenneté et nation à leère de la globalisation néolibérale », Nuevo Mundo Mundos Nuevos, disponívell em : http://nuevomundo.revues.org/59991 (acessado em dezembro de 2012). . (2010c), « Cet obscur objet du désir... multiculticulturel (III) : indianité, citoyenneté et nation à leè̀re de la globalisation néolibérale », Nuevo Mundo Mundos Nuevos, disponívell em : http://nuevomundo.revues.org/59984 (acesado em dezembro de 2012).

BÖRTH, Carlos. (2009), “Cuarenta días que conmovieron a Bolivia y unpacto político forzado", In: Carlos Romero et al., Del conflicto al diálogo. Memorias del acuerdo constitucional, fBDM, FES-ILDIS, pp. 59-106.

BOURDIEU, Pierre. (2013 [1994]), Razões práticas, Campinas : Papirus Editora.

CALDERON, Fernando. (2002), Política y sociedad en el espejo, La Paz: Plural Editores e PNUD.

CALDERON, Fernando; GAMARRA, Eduardo. (2004), Crisis y reforma de los partidos en Bolivia, La Paz: PNUD.

CANESSA, Andrew. (2006), “Todos somos indígenas: Towards a New Language of National Political Identity", Bulletin of Latin American Research, 25(2), pp. 241-263.

CHAVEZ, Patricia; Dunia Mokrani. (2007), "Los movimientos sociales en la Asamblea Constituyente. Hacia La reconfiguración de la política”, OSAL, (22), pp. 107-117.

CHAVEZ LEON, Marxa Nadia. (2008), “,Autonomías indígenase y „Estado Plurinacional $^{\text {eo, }}$ OSAL, (24), pp. 51-71. 
CHOQUE, María Eugenia; Carlos Mamani. (2001), "Reconstitución del ayllu y derechos de los pueblos indígenas: el movimiento indio en los Andes de Bolivia", The Journal of Latin American Anthropology, 6(1), pp. 202-224.

COLQUE, Gonzalo. (2009), Autonomías indígenas en tierras altas Breve mapeo para la implementación de la Autonomía Indígena Originaria Campesina, La Paz: Fundación Tierra.

CONAMAQ. (2008), Plan estratégico 2008-2013.

Constitución Política del Estado, Fevereiro 2009.

CRABTREE, John. (2005), Patterns of Protest: Politics and Social Movements in Bolivia, Londres: Latin American Bureau.

CRESS, Daniel M.; David A. Snow. (2000), “The Outcomes of Homeless Mobilization: The Influence of Organization, Disruption, Political Mediation, and Framing", American Journal of Sociology, 105(4), pp.1063-1104.

CSUTCB. (1983),Tesis Política. . (1984), Ley Agraria Fundamental.

DÍAZ-POLANCO, Héctor. (2006 [1991]), Autonomía Regional, la autodeterminación de los pueblos indios, México D.F.: Siglo Veintiuno Editores.

DO ALTO, Hervé. (2011), “Un partido campesino en el poderUna mirada sociológica del mas boliviano", Nueva Sociedad, 234, pp. 95-111.

DO ALTO, Hervé; Pablo Stefanoni. (2010), "El MAS: las ambivalencias de la democracia corporativa", In: Luis Alberto García Orellana; Fernando Luis García Yapur (coord.), Mutaciones del campo político en Bolivia, PNUD-Bolivia.

DOBRY, Michel. (1992 [1986]), Sociologie des crises politiques, Paris : Presses de la Fondation Nationale des Sciences Politiques.

DUNKERLEY, James. (2003 [1987]), Rebelión en las venas. La lucha política en Bolivia 1952-1982, La Paz: Plural Editores. . (2007), "Evo Morales, the „Two Boliviase and the Third Bolivian Revolution”.Journal of Latin American Studies, 39 (1), pp.133-166. ÉGIDO, (2010). Bolivia en la senda de implementación de la Ley Marco de Autonomías y Descentralización (LMAD), La Paz: Konrad Adenauer Stiftung; Editora Presencia. ESCÓBAR, Filemón. (2008), De la Revolución al Pachakuti. El aprendizaje del Respeto Recíproco entre blancos e indianos, La Paz: Garzazul Impresores y Editores. 
ESPOSITO, Carla. (2010), "El 11 de enero en Cochabamba. Apuntes para explicar los significadosde la violencia racista", Cuadernos de estudios sociales urbanos, 6, pp. 725 .

FLIGSTEIN, Neil. (2012), A Theory of Fields, New York: Oxford University Press. FORAN, John. (1993), "Theories of Revolution Revisited: Toward a Fourth Generation?",Sociological Theory, 11 (1), pp. 1-20.

FREITAS, Caroline Cotta de Melo. (2012), Entre wiphalas, polleras e ponchos. Embates entre os discursos de CONAMAQ, do Estado Plurinacional da Bolívia e do Direito Internacional, Tese de Doutorado. São Paulo: USP/ Programa de Pós-graduação em Antropologia Social.

FUNDACION TIERRA. (2011a), "Dos meses de marcha en defensa del TIPNIS", NuestraTierra, ano 2, 7.

. (2011b), Marcha indígena por el TIPNIS. La lucha en defensa de los territorios, La Paz: Fundación Tierra.

GARCÉS, Fernando. (2010a), "Los esfuerzos de construcción descolonizada de un Estado plurinacional en Bolivia y los riesgos de vestir al mismo caballero con otro terno", Integra Educativa, 3(1), pp. 49-66. . (2010b), El Pacto de Unidad y el Proceso de Construcción de una

Propuesta de Constitución Política del Estado, disponível em http://www.redunitas.org/PACTO_UNIDAD.pdf. . (2013), Los indigenas y su Estado (pluri)nacional: una mirada al proceso constituyente boliviano, Cochabamba: Jaina, Clacso, UMSS.

GARCIA LINERA, Álvaro. (2003a), “Autonomías regionales indígenas y estado multicultural", In: Vladimir Ameller, La descentralización que se viene, La Paz: Instituto Latinoamericano de Investigaciones Sociales e Plural, pp. 169-201. . (2003b), "La sublevación indígena popular en Bolivia", Chiapas, 14, pp. 71-88. . (2007), "Estado Plurinacional”, In: Álvaro Garcia Linera; Luis Tapia; Raúl Prada (org). La transformación pluralista del Estado, La Paz: Muela del Diablo, pp. 21-92. . (2008a), "Indianismo e Marxismo. O desencontro de duas razões revolucionárias", Encarte Clacso. Cadernos de América Latina, (2), pp.1-5. 
(2008b), La potencia plebeya. Acción colectiva $e$

identidades indígenas, obreras y populares en Bolivia, Buenos Aires: Prometeo libros e CLACSO Coediciones.

GARCIA LINERA, Álvaro et al. (2008 [2004]), Sociología de los movimientos sociales en Bolivia. Estructuras de movilización, repertorios culturales y acción política, La Paz: Plural Editores.

GILLY, Adolfo. (2011), "Historias desde adentro: La tenaz persistencia de los tiempos", In: Forrest Hylton et al., Ya es otro tiempo el presente. Cuatro momentos de insurgencia indígena, La Paz: Muella del Diablo Editores.

GOLDSTONE, Jack. (1991), Revolution and Rebellion in the Early Modern World, Berkley: University of California Press.

. (2003), States, Parties and Social Movements.Cambridge:

Cambridge University Press.

GONZÁlEZ CASANOVA, Pablo. (2003), “Colonialismo Interno. Una redefinición”, disponível

em:

http://bibliotecavirtual.clacso.org.ar/ar/libros/campus/marxis/P4C2Casanova.pdf

GOODWIN, Jeff. (2001), No Other Way Out.States and Revolutionary Movements, 1945-1991, New York: Cambridge University Press.

GROSS, Christian. (1999), "Ser diferente por (para) ser moderno. Las paradojas de la identidad", Analisis Politico, (36), pp.3-20.

GUARACHI, Paulino. (2005), Patarami. La vida en torno a la tierra, Fundación Tierra.

Disponível em: https://idl-bnc.idrc.ca/dspace/bitstream/10625/35883/1/121687_v10.pdf, consultado em maio de 2014.

GUERY, René; Rubén Chambi; Fernando Claros. (2010), La reconstitución del Jach 'a Suyu y la Nación Pakajaqi. Entre el poder local y la colonialidad del derecho indígena, La Paz: Fundación PIEB.

GUTIÉRREZ, Raquel; Fabiola Escárzaga (org.). (2005), Movimiento indígena en América Latina: resistencia y proyecto alternativo, Puebla/ Cidade do México: Gobierno del Distrito Federal/ Casa Juan Pablos/ Benemérita Universidad Autónoma de Puebla/ Universidad Nacional Autónoma de México/ Universidad Autónoma de la Ciudad de México.

(org.). (2007), Movimiento indígena en

América Latina: resistencia y proyecto alternativo. Volumen II, Puebla/ Cidade do México: Gobierno del Distrito Federal/ Casa Juan Pablos/ Benemérita Universidad 
Autónoma de Puebla/ Universidad Nacional Autónoma de México/ Universidad Autónoma de la Ciudad de México.

GUTIÉRREZ AGUILAR, Raquel. (2008), Los ritmos del Pachakuti, La Paz: Textos Rebeldes.

HAHN, Dwight. (1996), "The Use and Abuse of Ethnicity: The Case of the Bolivian" CSUTCB, Latin American Perspectives, 23(2), pp. 91-106.

HEALEY, Susan. (2009), "Ethno-Ecological Identity and the Restructuring of Political Power in Bolivia”, Latin American Perspectives, 36(4), pp. 83-100.

HYLTON, Forrest; Sinclair Thomson.(2005), "The chequered rainbow", New Left Review, 35(1), pp. 41-64.

HYLTON, Forrest et al. (2011), Ya es otro tiempo el presente. Cuatro momentos de insurgencia indígena, La Paz: Muella del Diablo Editores.

IAMAMOTO,Sue Angelica Serra. (2009), Terra e Território. A luta pela descolonização na Bolívia. Trabalho de Conclusão de Cursoem Comunicação Social, São Paulo: USP.

(2011), O nacionalismo boliviano em tempos de plurinacionalidade: Revoltas antineoliberais e constituinte (2000-2009). Dissertação de mestrado, São Paulo: USP/ Programa de Pós-graduação em Ciência Política.

ITURRALDE G., Diego. (2000), "Lucha indígena y reforma neoliberal”, Iconos, Revista de Ciencias Sociales, (9), pp. 22-30.

KECK, Margaret E.; SIKKINK, Kathryn.(1998), Activists beyond borders. Advocacy networks in international politics. New York: Cornell University Press.

LAGOS, María L. (1997), Autonomía y Poder. Dinámicas de clase y cultura en Cochabamba. La Paz: Plural.

LAZARTE, Jorge. (2009), "Plurinacionalismo y multiculturalismo en la Asamblea Constituyente de Bolivia”, In: Revista Internacional de Filosofía Política,33, pp. 71-107. MAMANI, Pablo. (2003), Simbología y poder indígena después de los Kataris-Amarus y Willkas: Los Mallkus en los nuevos levantamientos indígenas en Bolivia. Disponível em: http://www.mapuche.info/mapuint/mamani030600.html. . (2005), Microgobiernos Barriales. Levantamiento de la ciudad de El Alto, La Paz : CADES.

. (2007), "Bolivia antes de Evo Morales. Fractura del Estado Colonial. Poder de los microgobiernos indígenas", Bolivian Studies Journal, 7(1), pp. 1-26. (2009), "Presentación", Revista Willka, 3, pp. 7-13. 
(2009), "Estado Plurinacional: entre el nuevo proyecto y la factura colonial", Revista Willka, 3, pp. 31-67.

MARIÁTEGUI, José Carlos. (2010), Sete Ensaios de Interpretação da Realidade Peruana, São Paulo: Expressão Popular.

MARTIN, Denis-Constant (org). (1994), Cartes D’Identité. Comment dit-on 'nous' en politique?, Paris : Presses de la Fondation Nationale des Sciences Politiques.

MATHIEU, Lilian. (2004), "Notes provisoires sur l'espace des mouvements sociaux", ContreTemps, 11, pp.51-59.

. (2005), "L“espace des mouvements sociaux", participation au 8ème

Congrès de $1^{\text {ee } A F S P, ~ L y o n, ~}$

http://www.afsp.msh-

paris.fr/archives/congreslyon2005/communications/tr1/mathieu.pdf

MAYORGA, Fernando. (2009), La nueva conyuntura critica de los paises andinos, Lima: IEP Instituto de Estudios Peruanos; IDEA Internacional.

McADAM, Doug. (1994), "Culture and Social Movements”, In: Joseph R. Gusfield, Hank Johnston; Enrique Laraña (org.), Ideology and Identity in Contemporary Social Movements, Philadelphia: Temple University Press, pp. 36-57.

; John McCarthy; Mayer Zald (org.).(1996), Comparative

Perspectives on Social Movements. Political Opportunities, Mobilizing Structures, and Cultural Framings, Cambridge: Cambridge University Press.

; Charles Tilly; Sidney Tarrow.(2001), Dynamics of contention, Cambridge, Cambridge University Press.

McNEISH, John-Andrew. (2006), "Stones on the Road: The Politics of Participation and the Generation of Crisis in Bolivia”, Bulletin of Latin American Research, 25(2), pp. 220-240.

MIRANDA, Boris. (2012), La mañana después de la guerra, La Paz: Editorial El Cuervo.

MOLINA, Wilder. (2008), “Autonomías y posiciones identitarias en la región amazónica de Bolivia”, Tinkazos, 11 (23-24), pp. 171-181.

MORAES, Renata Albuquerque. (2014), Desenvolvimento e vivir bien. O caso do Território Indígena e Parque Nacional Isiboro Sécure (Bolívia). Dissertação de mestrado, Brasilia: UnB/ Programa de Pós-Graduação em Estudos Comparados sobre as Américas.

NEVEU, Erik. (2005),Sociologie des mouvements sociaux, Paris: La Découverte. 
NUÑEZ, Elogio Aramayo. (2009) "El acceso de campesinos indígenas a la tierraes estratégico, ¿Qué presupuesto le asigna el Estado?”, Mundos rurales, (1), pp. 16-20.

OLIVERA, Oscar et al. (2008), Nosotros somos la Coordinadora, La Paz: Fundación Abril, Textos Rebeldes.

ORDÓÑEZ CIFUENTES, José Emilio Rolando. (2007), Reflexiones Lascasianas. Antecedentes Doctrinarios en Materia de los Derechos de los Pueblos Originarios, Cidade do México: Tinta Negra Editores.

OTERO, Gerardo; Heide A. Jugenitz.(2003), "Challenging National Borders from Within: The Political-Class Formation of Indigenous Peasants in Latin America", Canadian Review of Sociology and Anthropology, 40(5), pp. 503-524.

PANNAIN, Rafaela N. (2008), “La fabricación de la démocratie en Amérique latine par l“Agence des États-Unis pour le dévelopoement internacional”. Mémoire de Master 2. Paris: Université Paris 1, Panthéon-Sorbonne.

PATZI, Félix. (2007), Insurgencia y sumisión. Movimientos sociales e indígenas., La Paz: Ediciones Yachaywasi.

(2011), "Rebelión indígena contra la colonialidad y la transnacionalización de la economía: Triunfos y vicisitudes del movimiento indígena desde 2000 a 2003”, In: Forrest Hylton et al., Ya es otro tiempo el presente. Cuatro momentos de insurgencia indígena, La Paz: Muella del Diablo Editores, pp. 189-262.

PAZ, Sarela. (2011), "El conflicto del territorio indígena Parque Nacional Isiboro Sécure (TIPNIS) y sus consecuencias para el Estado Plurinacional de Bolivia", disponível em: http://www.fbdm.org.bo/fbdm/documento/1290176707/1320853790/21320853790.pdf.

PECHU, Cécile. (2001), "Les générations militantes à Droit au Logement", Revue française de science politique, 51 (1-2).

PEÑARANDA, Raúl. (2009), “Crónica del proceso constituyente”, In: Carlos Romero et al., Del conflicto al diálogo. Memorias del acuerdo constitucional, fBDM, FESILDIS, pp. 107-202.

PLATT, Tristan. (1987), "Entre cheaxwa y muxsa una historia del pensamiento aymara", In: Therèse Bouysse-Cassagne; Olivia Harris; Tristan Platt; Verónica Cerrada (org.), Tres reflexiones sobre el pensamiento andino, La Paz: Isbol.

POMA, Muruchi et al. (2008), Ponchos Rojos, La Paz: FODENPO, Plural.

POSTERO, Nancy Grey. (2005), "Movimientos indígenas bolivianos: articulaciones y fragmentaciones en búsqueda de multiculturalismo", In: Luiz Enrique López; Pablo 
Regalsky (org.), Movimientos Indígena y Estado en Bolivia, La Paz: PROEIB Andes, CENDA, Plural Editores, pp. 53-96. . (2009), Ahora somos ciudadanos, La Paz: Muella del Diablo.

PRADA, Raúl. (2003), "Perfiles del movimiento social contemporáneo. El conflicto social y político en Bolivia”, OSAL, 12, pp. 35- 46.

- (2010), “Umbrales y horizontes de la descolonización”In: Álvaro

Garcia Linera et al. Estado como campo de lucha, La Paz: CLACSO, Comuna, Muella del Diablo, pp. 43-96.

PUENTE, Florencia; Francisco Longa. (2007), "El Alto: los dilemas del indigenismo urbano", In: Maristella Svampa; Pablo Stefanoni (org.), Bolivia:Memoria, Insurgencia y Movimientos Sociales, Buenos Aires: Clacso.

QUIJANO, Anibal. (2005), "Colonialidade do poder, eurocentrismo e América Latina", In: Roberto Leher; Mariana Setúbal (org.), Pensamento Crítico e movimentos sociais: Diálogos para uma nova praxis, São Paulo: Cortez.

. (2006), "Don Quijote y los molinos de viento en América Latina", disponível em http://www.oeiperu.org/documentos/ClavesQuijano.pdf

QUISBERT, Máximo. (2009), "Hacia autonomías indígenas y sus riesgos latentes", Revista Willka, 3, pp. 93-145.

QUISPE, Felipe. (2013), La caída del Goni. Diario de la "Huela de Hambre”, Ediciones Pachakuti.

REGALSKY, Pablo. (2006), "Bolivia indígena y campesina. Una larga marcha para liberar sus territorios y un contexto para el gobierno de Evo Morales", Herramienta, (31).

. (2007), Etnicidad y clase, La Paz: Plural, $2^{\mathrm{a}}$ edição.

REGALSKY, Pablo; Francisco Quisbert. (2008), "Bolivia indígena: De gobiernos comunitarios en busca de autonomía a la lucha por la hegemonía”, In: Xochitl Leyva, Araceli Burguete e Shannon Speed (org.), Gobernar (en) la diversidad: experiencias indígenas desde América Latina. Hacia la investigación de co-labor, Equador: Publicaciones de la Casa Chata, pp. 150-187.

REINAGA, Fausto. (2001), La Revolución Índia, La Paz: Ediciones Fundación Amaútica "Fausto Reinaga".

RIVERA, Silvia. (1983), "Luchas campesinas contemporáneas en Bolivia: El movimiento "katarista”, 1970-1980”, In: René Zavaleta (org.), Bolivia Hoy, Siglo XXI, pp. 129-168. 
. (1990), "Liberal democracy and Ayllu Democracy in Bolivia: The

Case of Northern Potosí”, Journal of Development Studies, 26 (4), pp. 97-121.

. (1991), Pachakuti: The historical horizons of internal colonialism,

disponível

em

http://www.web.ca/ bthomson/degrowth/pachakuti_cusicanqui_1991.pdf. (2003 [1984]), Oprimidos pero no vencidos. Luchas del campesinato

aymara y quechwa 1900-1980, La Paz: Aruwiyiri - Editorial del Taller de Historia Oral Andino (THOA).

. (2007), "Que el pasado sea futuro depende de lo que hagamos en el presente. Enseñanzas de la insurgencia étnica en Bolivia”, In: Jesús Espasandín López; Pablo Iglesias Turrión (org.), Bolivia en movimiento. Acción colectiva y poder político, Barcelona: El Viejo Topo, pp. 101-127.

ROJAS, Gonzalo. (2009), Cultura política de las élites en Bolivia (1982-2005), La Paz: CIPCA e Friedrich Ebert Stiftung.

ROMERO BONIFAZ, Carlos. (2003), “Aportes a la territorialidade indígena em la Ley Agraria Fundamental”, Revista “Artículo Primero”, Separata (12), pp. 11-15. . (2005), El proceso constituyente boliviano, Cejis. . (2009), "Bases para ley marco de autonomías”, In: Carlos Romero; Carlos Böhrt Irahola, Autonomias. Se hace camino al andar, La Paz: fBDM, FES-ILDIS, PNUD, pp. 143-177.

SALLUM Jr., Brasílio. (1996), Labirintos. Dos generais à Nova República, São Paulo: Editora Hucitec.

SCHAVELZON, Salvador. (2010), A Assembleia Constituinte da Bolívia: Etnografia do Nascimento de um Estado Plurinacional. Tese de Doutorado. Rio de Janeiro: UFRJ/ Museu Nacional/ Programa de Pós-graduação em Antropologia Social.

SCHLEE, Günther. (2008), How Enemies are Made. Towards a Theory of Ethnic and Religious Conflicts, Nova York, Oxford: Berghahn Books.

SCHILLING-VACAFLOR, Almut. (2008), "Identidades indígenas y demandas politico-jurídicas de la csutcb y el conamaq en la Constituyente boliviana”, Tinkazos, 11(23-24), pp. 1-17.

SIVAK, Martín. (2008), Jefazo. Retrato íntimo de Evo Morales, Santa Cruz de la Sierra: Debate.

SKOCPOL, Theda. (1979). States and Social Revolutions: A Comparative Analysis of France, Russia and China, Cambridge: Cambridge University Press. 
SORUCO, Jimena (coord.), Los barones del Oriente. El poder en Santa Cruz ayer y hoy, Santa Cruz: Fundación Tierra.

SOUSA SANTOS, Boaventura de. (2013 [2010]), Refundación del Estado en America Latina. Perspectivas desde uns epistemología del Sur. La Paz: Plural Editores; CESUUMSS.

STEFANONI, Pablo. (2003), El nacionalismo indígena como identidad política:La emergencia del MAS-IPSP (1995-2003), Informe final del concurso: Movimientos sociales y nuevos conflictos en América Latina y el Caribe.Programa Regional de Becas CLACSO. 2002. Disponível em: http://bibliotecavirtual.clacso.org.ar/ar/libros/becas/2002/mov/stefanoni.pdf.

STEPHESON, Marcia. (2002), "The Taller de Historia Oral Andina in Bolivia”, Latin American Research Review, 36 (2), pp. 99-118.

STRÖBELE-GREGOR, Juliana. (1994), "From Indio to Mestizo... to Indio.New Indianist Movements in Bolivia”, Latin America Perspectives, 21(2), pp. 106-123. . (1996), "Culture and Political Practice of the Aymara and Quechua in Bolivia", Latin America Perspectives, 23(2), pp. 72-90.

TAPIA, Luis. (2005), "La cuarta derrota del neoliberalismo en Bolivia", OSAL, (17), pp. 153- 158 .

. (2007a), "Una reflexión sobre la idea de Estado plurinacional”, OSAL, (22), pp. 47-63. . (2007b), "Bolivia: ciclos y estructuras de la rebelión", In: Maristella Svampa; Pablo Stefanoni (org.), Bolivia:Memoria, Insurgencia y Movimientos Sociales, Buenos Aires: Clacso, pp.171-188.

. (2007c), "Gobierno multicultural y democracia directa nacional”. In: Álvaro Garcia Linera; Luis Tapia; Raúl Prada (org). La transformacion pluralista del Estado, La Paz: Muela del Diablo, pp. 93-197.

. (2010), "El estado en condiciones de abigarramiento" In: Álvaro Garcia Linera et al. Estado como campo de lucha, La Paz: CLACSO, Comuna, Muella del Diablo, pp. 97-128.

TARROW, Sidney. (1998), Power in movement: social movements and contentious politics, Cambridge: Cambridge University Press, $2^{\mathrm{a}}$ Ed.

; Sidney Tarrow. (2008), Politique(s) du conflit. De la grève à la révolution, Paris, Les Presses de Science Po. 


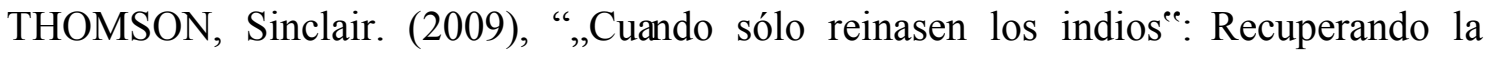
variedad de proyectos anticoloniales entre los comunarios andinas (La Paz, 17401781)", In:Forrest Hylton et al., Ya es otro tiempo el presente. Cuatro momentos de insurgencia indígena, La Paz: Muella del Diablo Editores.

TICONA, Esteban. (2003), "Pueblos indígenas y Estado boliviano. La larga historia de conflitos", Gazeta de Antropologia, (19).

. (2010), "La producción del conocimiento descolonizador en contextos de colonialismo interno". Integra Educativa, 3(1), pp. 37-48.

TININI, Ninoska. (2009), "De un Estado multiétnico y plurinacional hacia un Estado plurinacional", Revista Willka, 3, pp. 15-27.

URIOSTE, Miguel et al. (2007), Los nietos de la reforma agraria, La Paz: Fundación Tierra; CIPCA.

URQUIDI, Vivian. (2007), Movimento cocaleiro na Bolívia, São Paulo: Editora Hucitec.

URIQUIDI, Vivian et al. (2008), “Questão Indígena na América Latina: Direito Internacional, Novo Constitucionalismo e Organização dos Movimentos Indígenas”, Cadernos PROLAM/USP, 8 (1), pp. 199-222.

VALENCIA, María del Pilar; ÉGIDO, Ivan. Los publos indígenas de las tierras bajas en el proceso constituyente, Cejis; Editorial Imprenta El País.

VAN COTT, Donna Lee. (2003), "From Exclusion to Inclusion: Bolivia's 2002 Elections", Journal of Latin American Studies, 35(4), pp.751-775. . (2005), Form movements to parties in Latin America. The Evolution of Ethnic Politics, Cambridge: Cambridge University Press.

VEGA CAMACHO, Oscar. (2007), "Reflexiones sobre la transformación pluralista", In: Álvaro Garcia Linera; Luis Tapia; Raúl Prada (org). La transformación pluralista del Estado, La Paz: Muela del Diablo, pp. 7-18. . (2010), "Estado plurinacional. Elementos para el debate", In: Oscar Vega Camacho et al. Descolonización en Bolivia. Cuatro ejes para comprender el cambio, La Paz: Vicepresidencia del Estado Plurinacional de Bolivia; Fundación Boliviana para la Democracia Multipartidaria, pp. 109-134.

VIANA, Jorge; Luis Claros; Marcelo Sarzuri-Lima. (2010), "La condición colonial y los laberintos de la descolonización", Integra Educativa, 3(1), pp. 13-36. 
WANDERLEY, Fernanda. (2009), "Personalidade Jurídica e Cidadania Coletiva naBolívia: Uma Etnografia da Identificação Jurídicae a Formação de Espaços Públicos”, Dados Revista de Ciências Sociais, 52 (3), pp. 581-619.

WARREN, Kay B. (2000), “Os movimentos indígenas como um desafio ao paradigma do movimento social unificado na Guatemala”, In: Sonia E. Alvarez; Evelina Dagnino; Arturo Escobar (org.), Cultura e Política nos Movimentos Sociais Latino-Americanos. Novas Leituras, Belo Horizonte: Editora UFMG, pp. 257-299.

WEBBER, Jeffrey. (2005), "Left-Indigenous Strugles in Bolivia”, Monthly Review, 57 (4), pp. 34-48.

- (2007), "Critical Debates.Indigenous Struggle in Latin America: The Perilous Invisibility of Capital and Class", Latin American Politics and Society, 49(3), pp. 191-205.

. (2010), “Carlos Mesa, Evo Morales, and a Divided Bolivia (20032005)", Latin American Perspectives, 37 (3), pp. 51-70.

YASHAR, Deborah. (1998), "Indigenous Movements and Democracy in Latin America", Comparative Politics, 31(1), pp. 23-42.

ZAVALETA MERCADO, René. (1983), “Las masas en noviembre”, In: René Zavaleta (org.), Bolivia Hoy, Siglo XXI, pp. 11-59.

- (2008), Lo nacional-popular en Bolivia, La Paz:

Plural Editores. 


\section{Anexo 1: Mapa político da Bolívia}

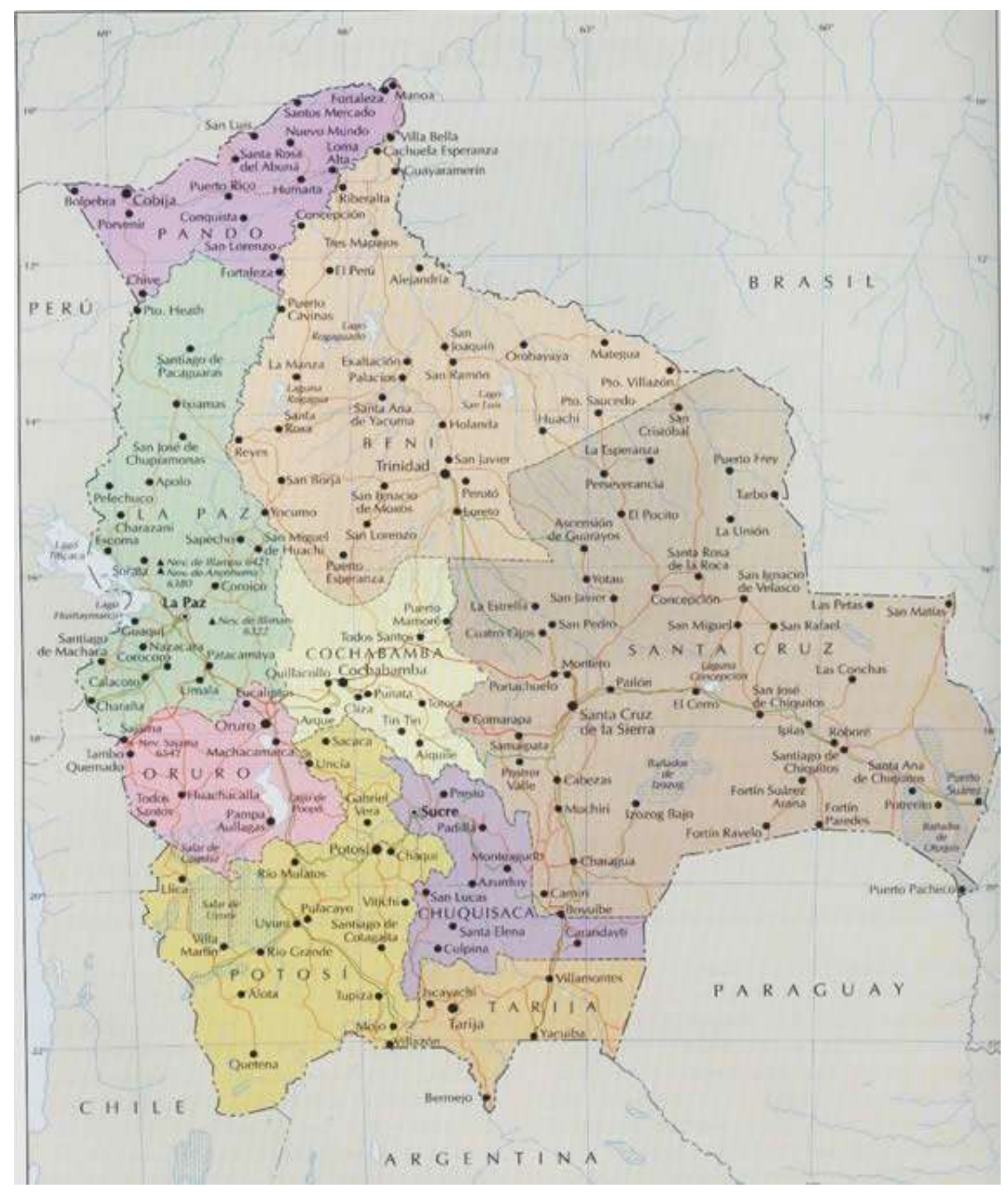

Fonte: http://universoguia.com/wp-content/uploads/2013/04/politicobolivia.jpg. 


\section{Anexo 2: Mapa físico da Bolívia}

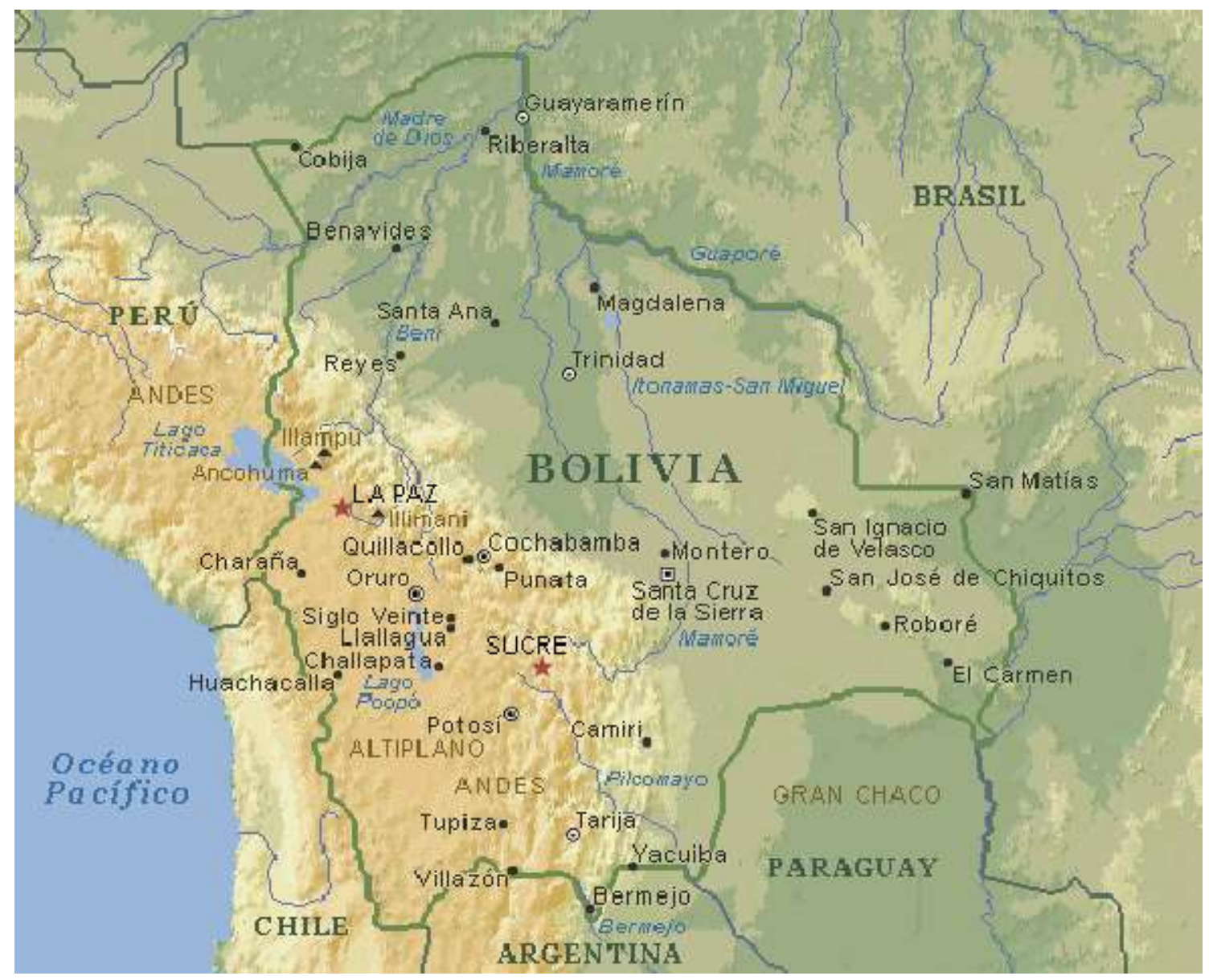

Fonte: http://universoguia.com/wp-content/uploads/2013/04/Mapa-fisico-de-Bolivia.gif. 
Anexo 3: Mapa da Bolívia com as Terras Comunitárias de Origem

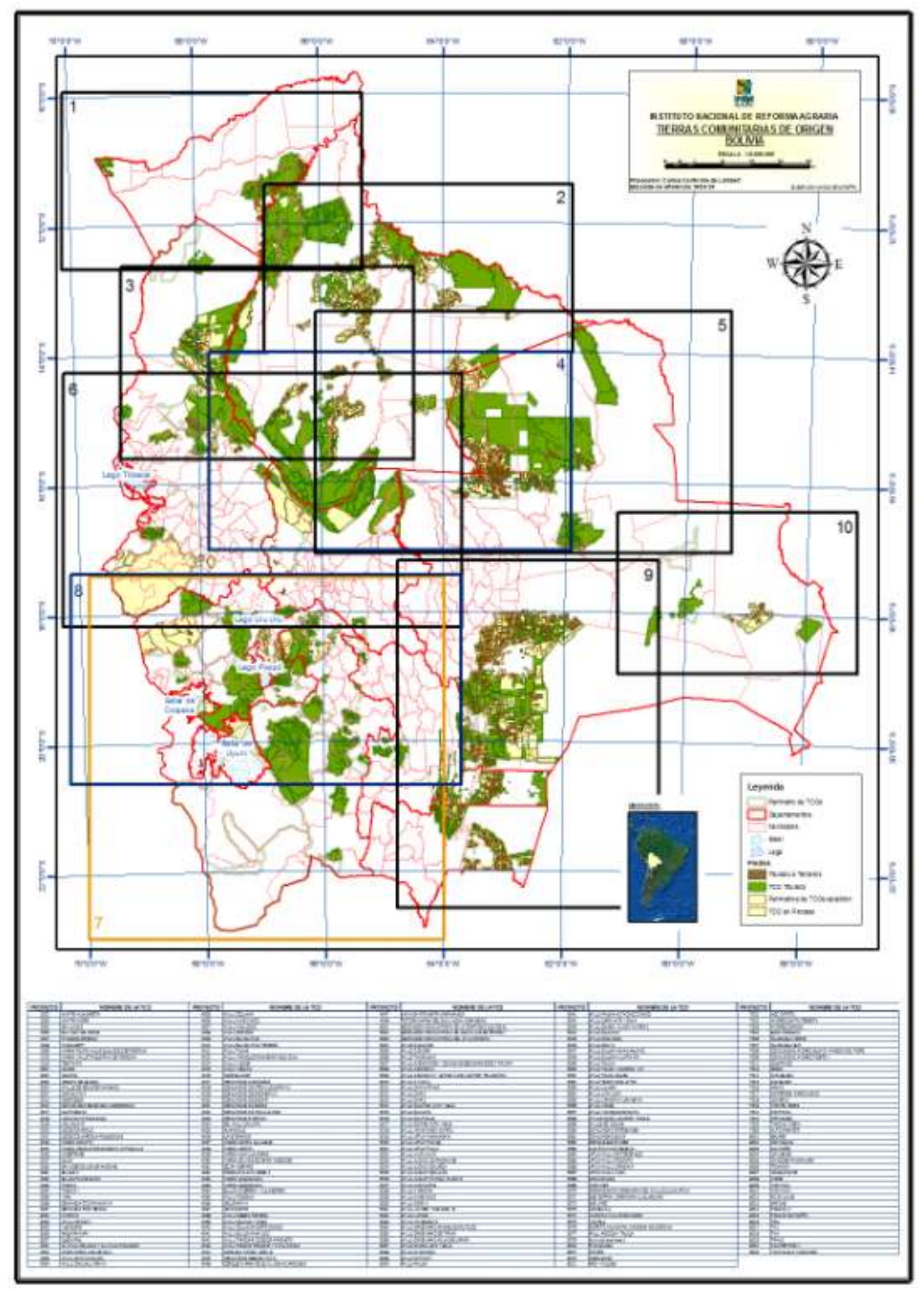




\section{Anexo 4: Mapa do Município de Charagua}

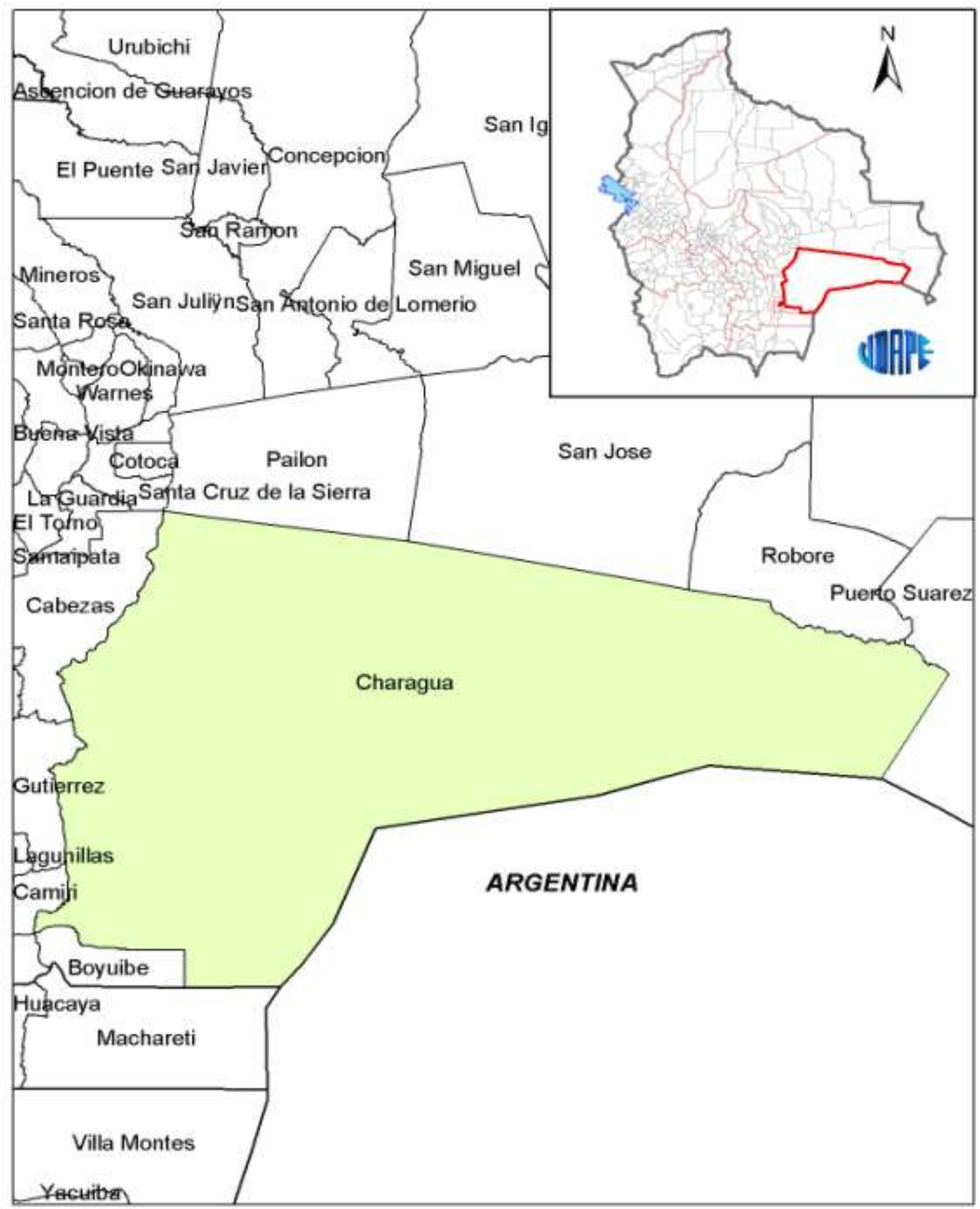

Fonte: Unidad de Análisis de Políticas Sociales y Económicas. Estado Plurinacional de Bolivia. 
Anexo 5: Mapa da região do Chaco de Santa Cruz, Chuquisaca e Tarija com as Terras Comunitárias de Origem

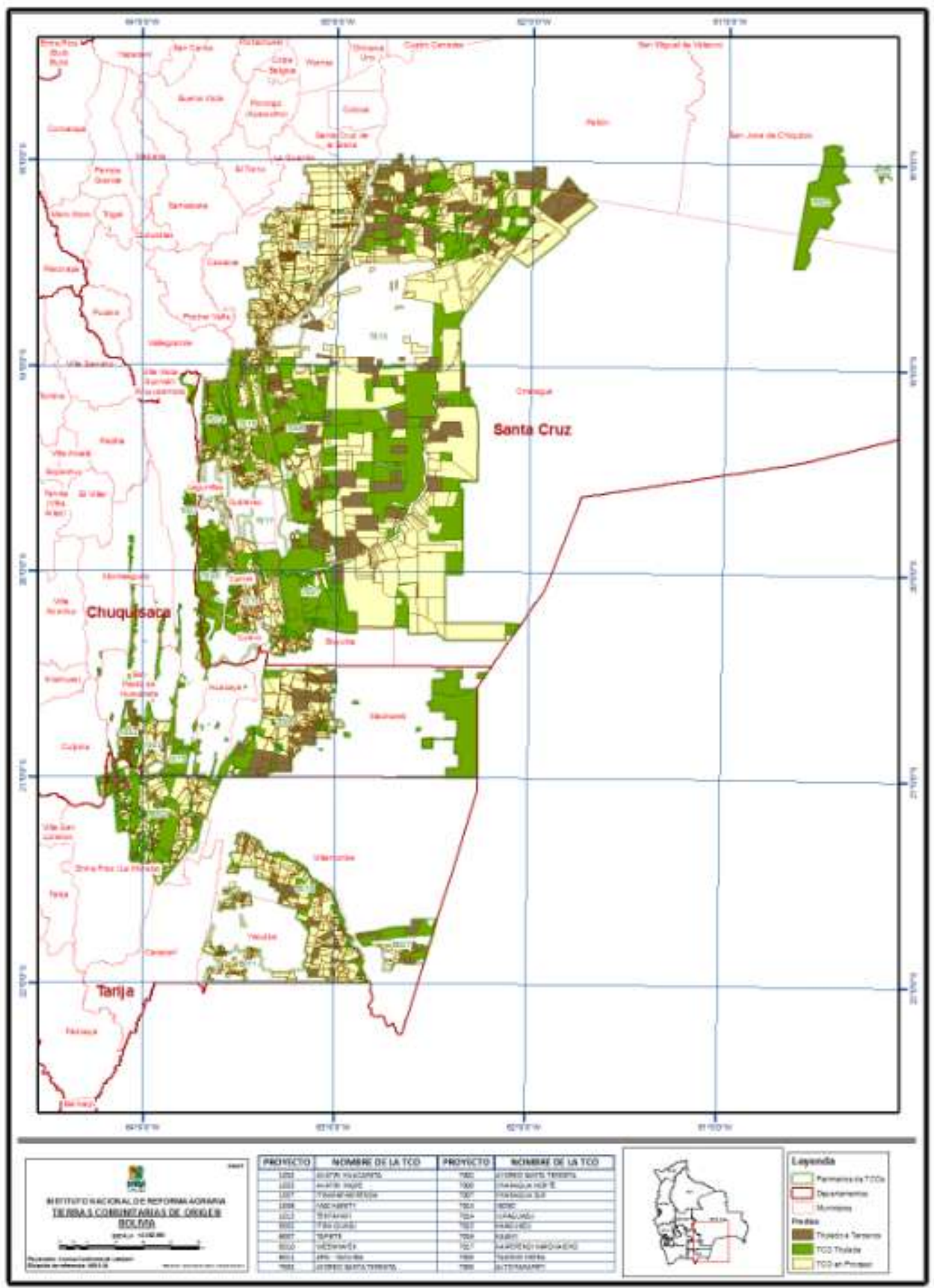




\section{Anexo 6: Anexo Fotográfico}

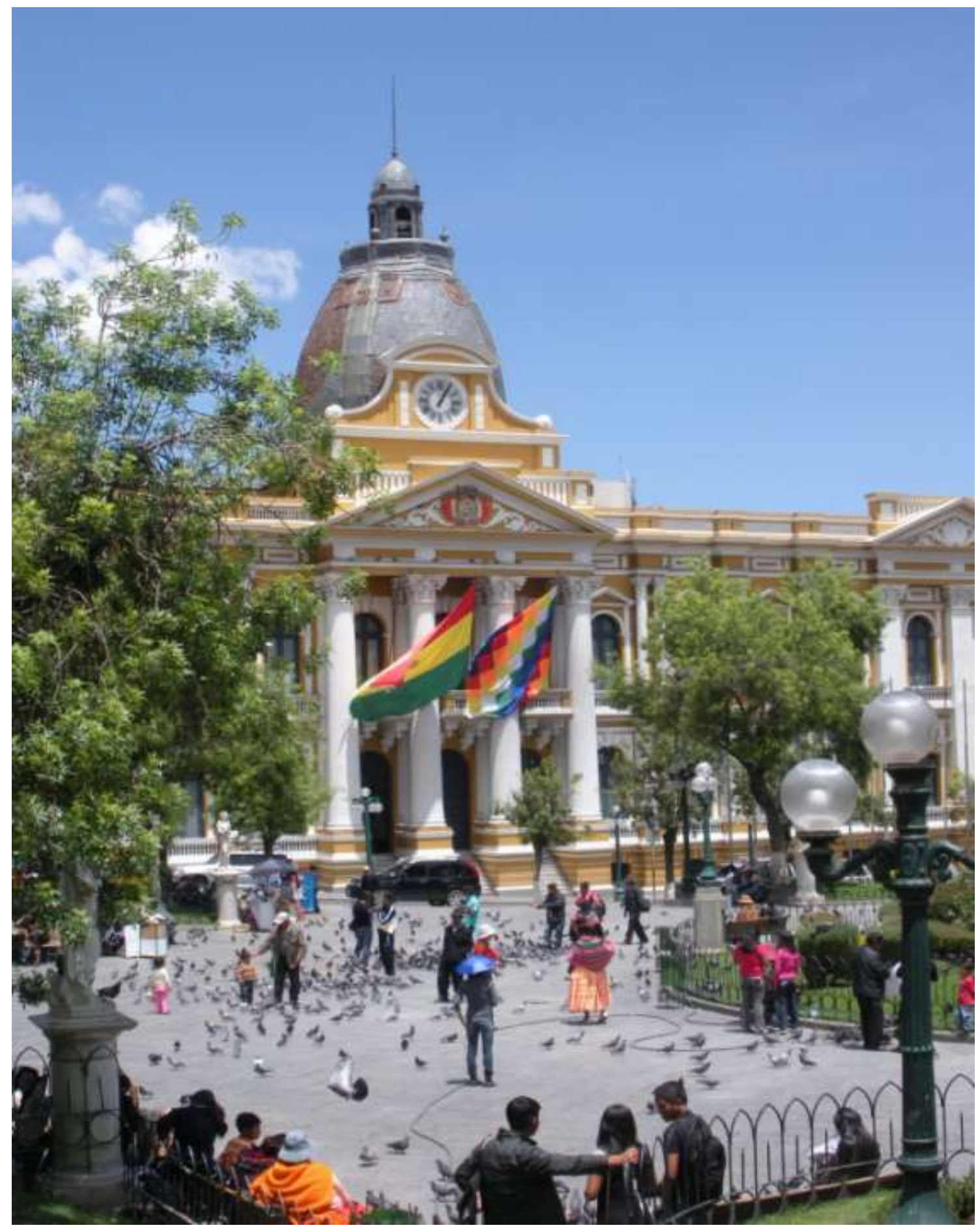

Assembleia Plurinacional da Bolívia, La Paz: A whilpala, bandeira adotada pelos movimentos indígenas, é um dos símbolos do novo Estado Plurinacional da Bolívia. Autora: Rafaela Nunes Pannain, novembro de 2012. 


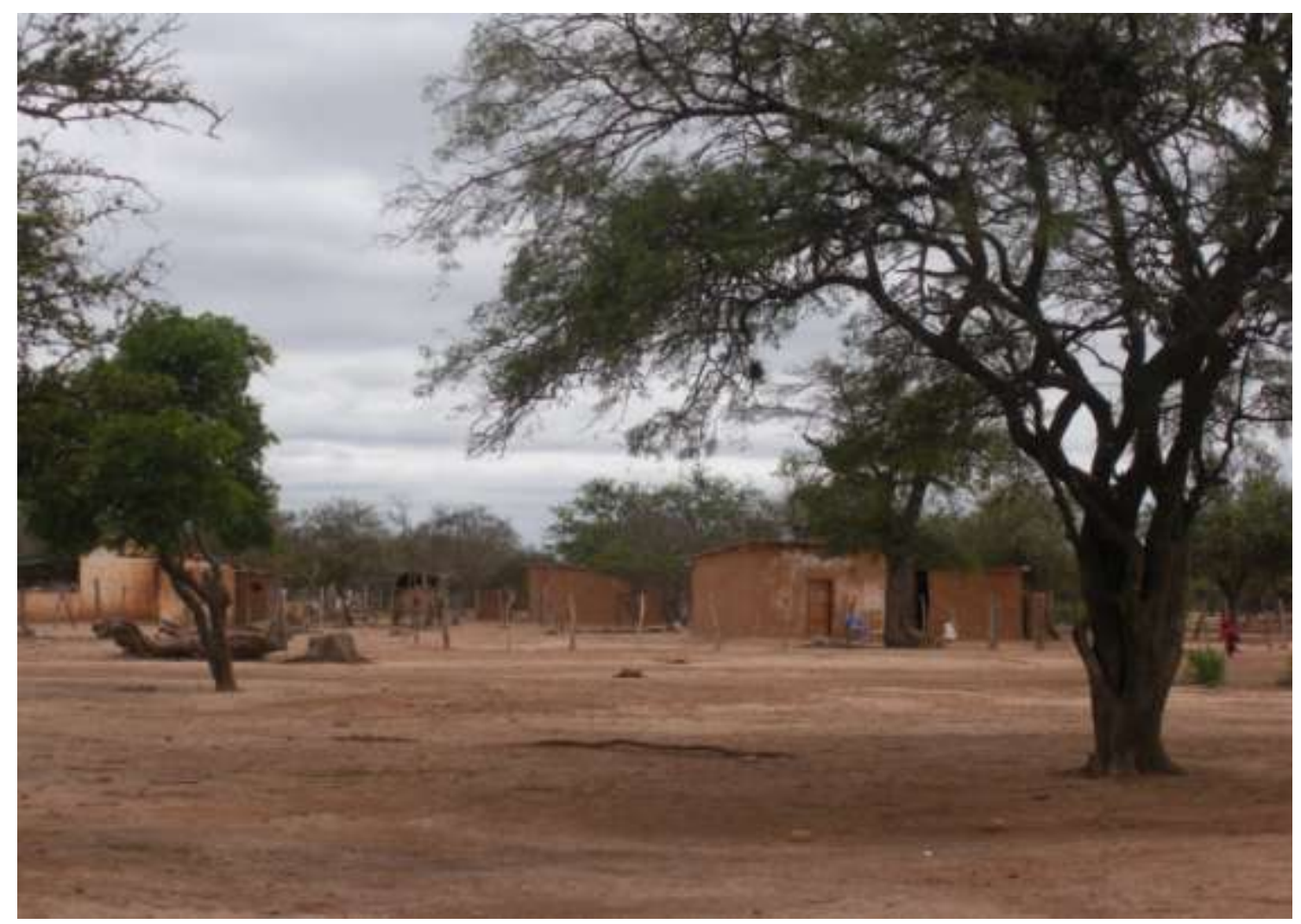

Comunidade de Arakuarenda, Bajo Isoso, Charagua.

Autora: Rafaela Nunes Pannain, junho de 2013.

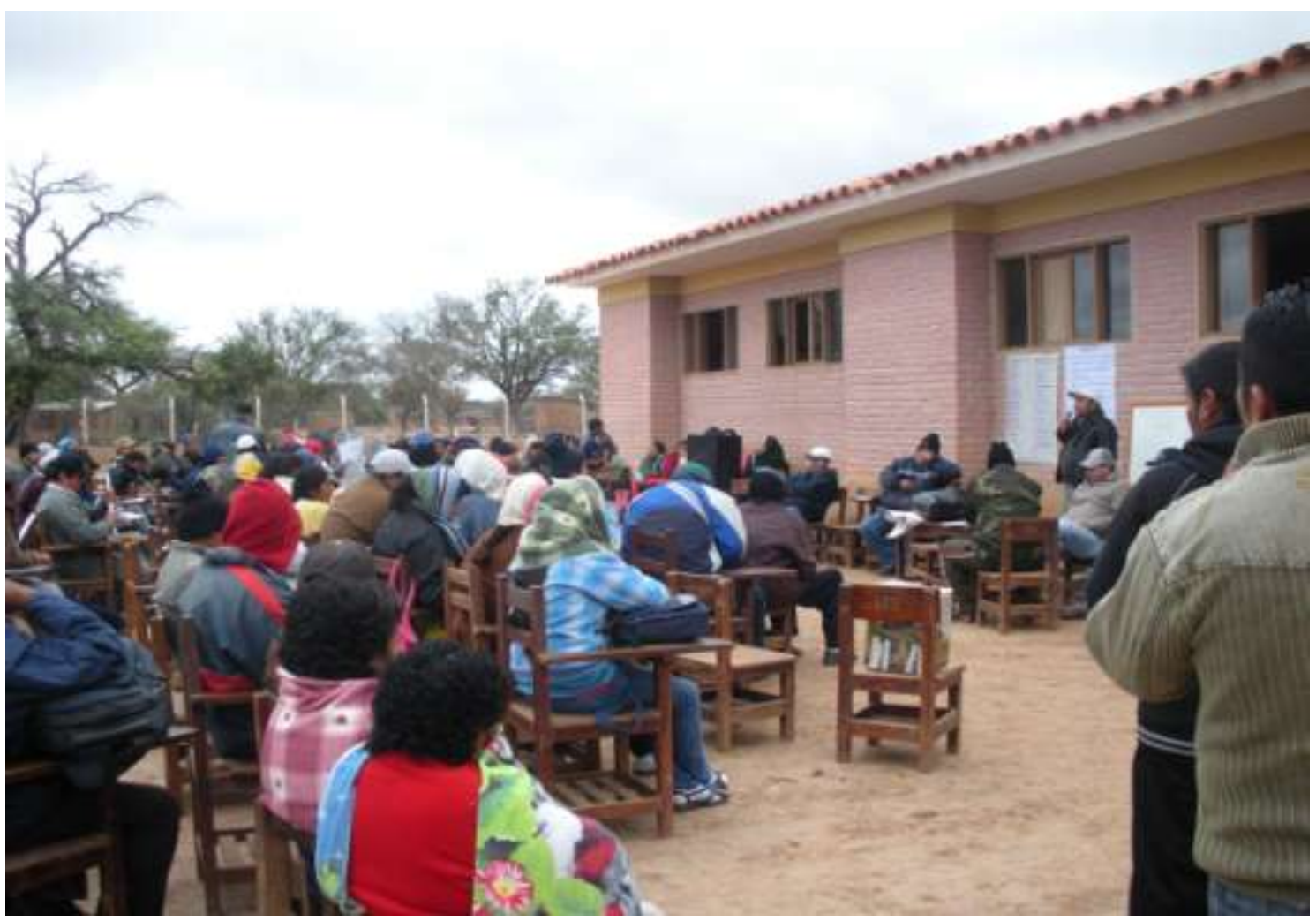

Assembleia zonal de Bajo Isoso, Charagua. Socialização do Estatuto Autonômico. Autora: Rafaela Nunes Pannain, junho de 2013. 


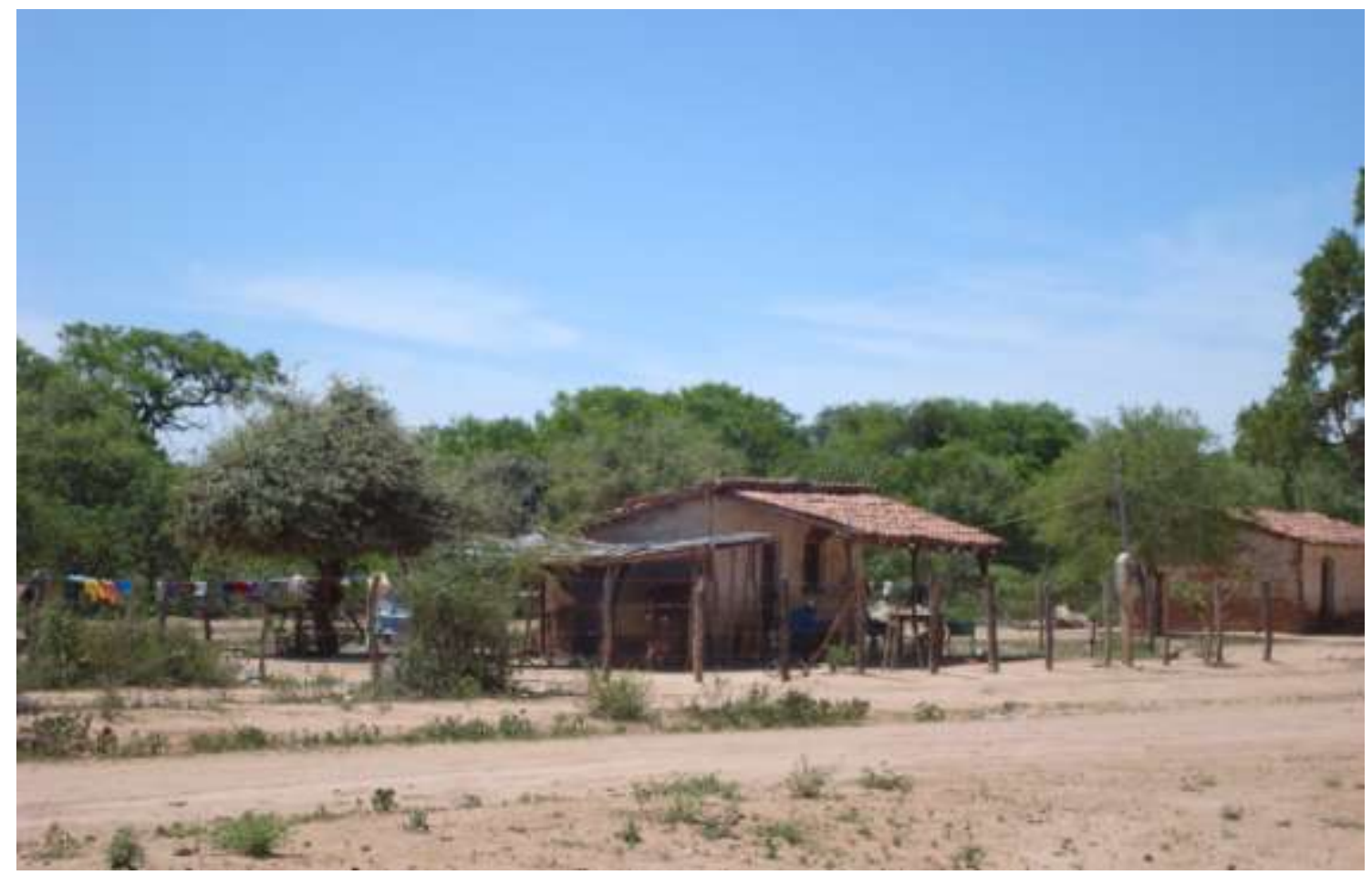

Comunidade de San Antonio, Parapitiguasu, Charagua.

Autora: Rafaela Nunes Pannain, novembro de 2013.

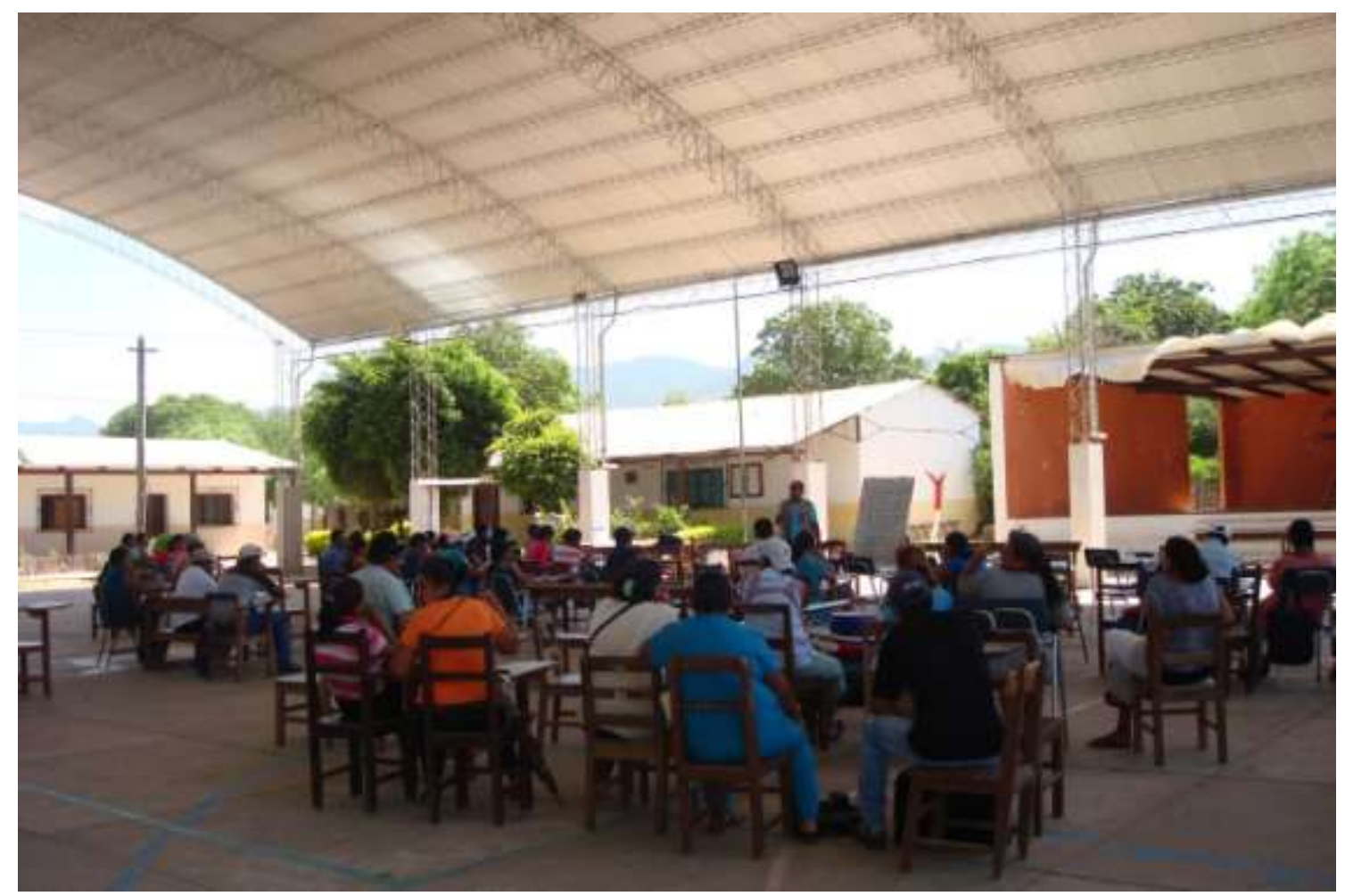

Socialização do Estatuto Autonômico comprofessores da Capitania de Parapitiguasu. Autora: Rafaela Nunes Pannain, novembro de 2013. 


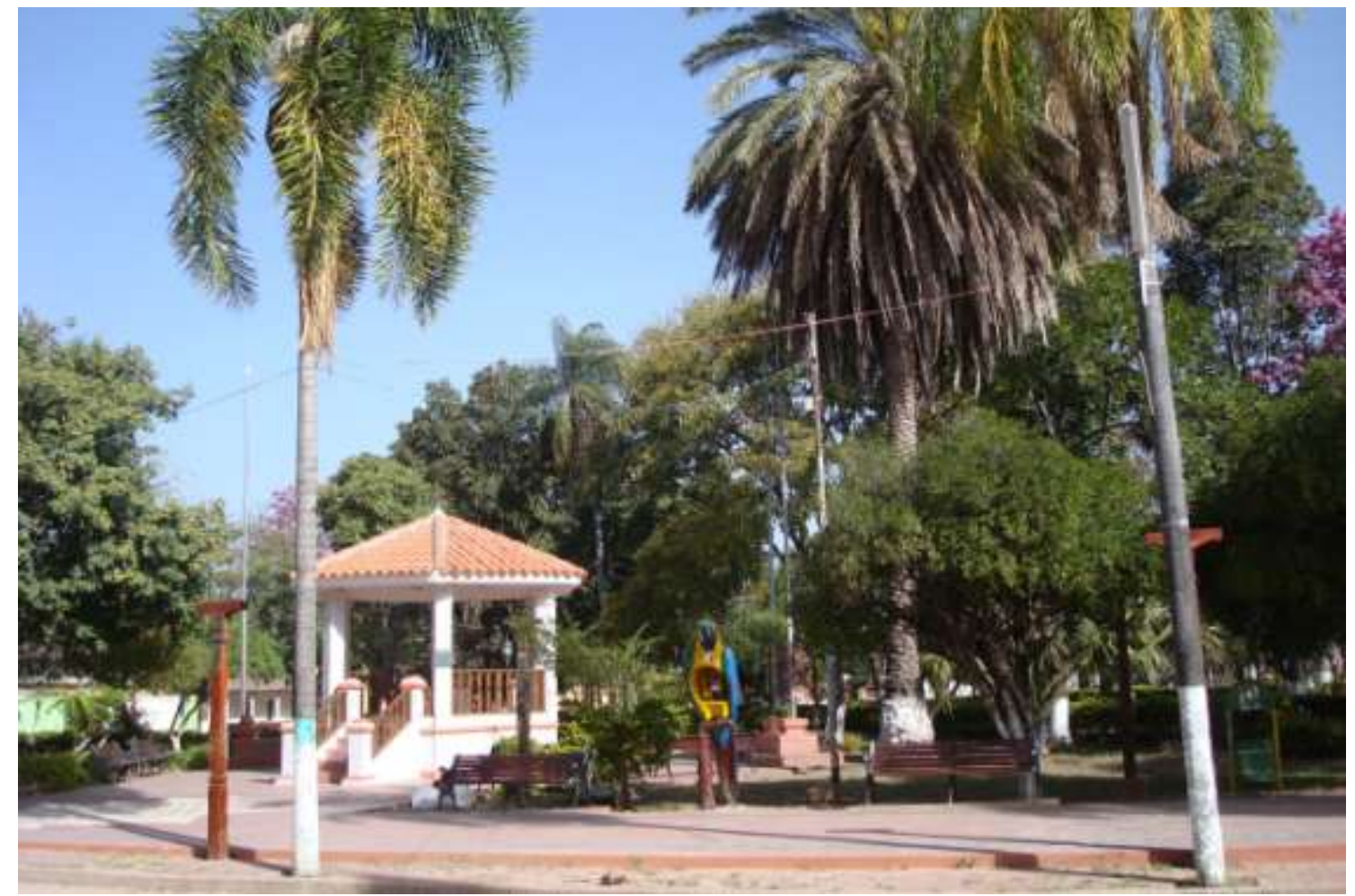

Praça principal de Charagua Pueblo, Charagua.

Autora: Rafaela Nunes Pannain, setembro de 2013.

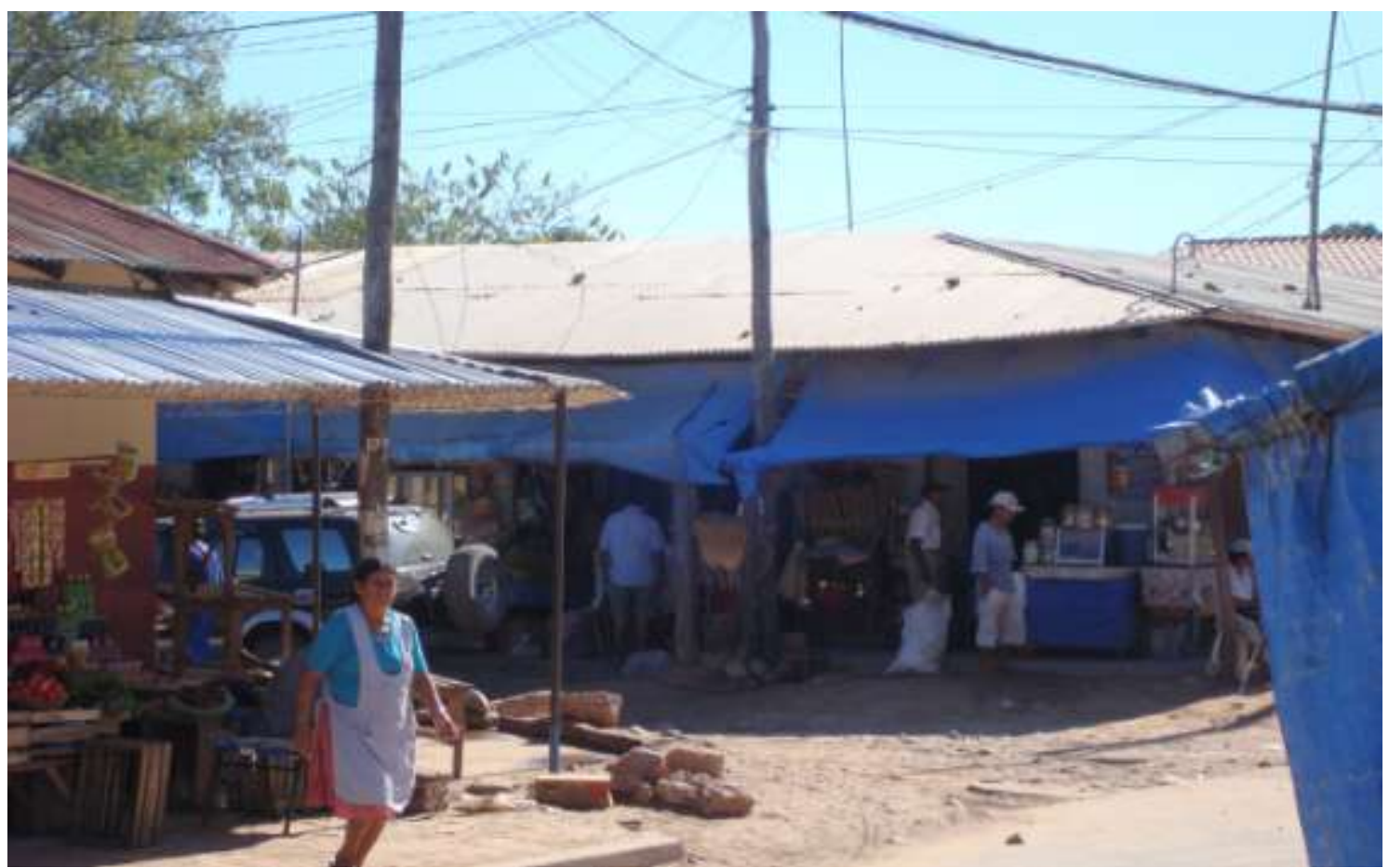

Mercado em Charagua Pueblo, Charagua.

Autora: Rafaela Nunes Pannain, novembro de 2013. 


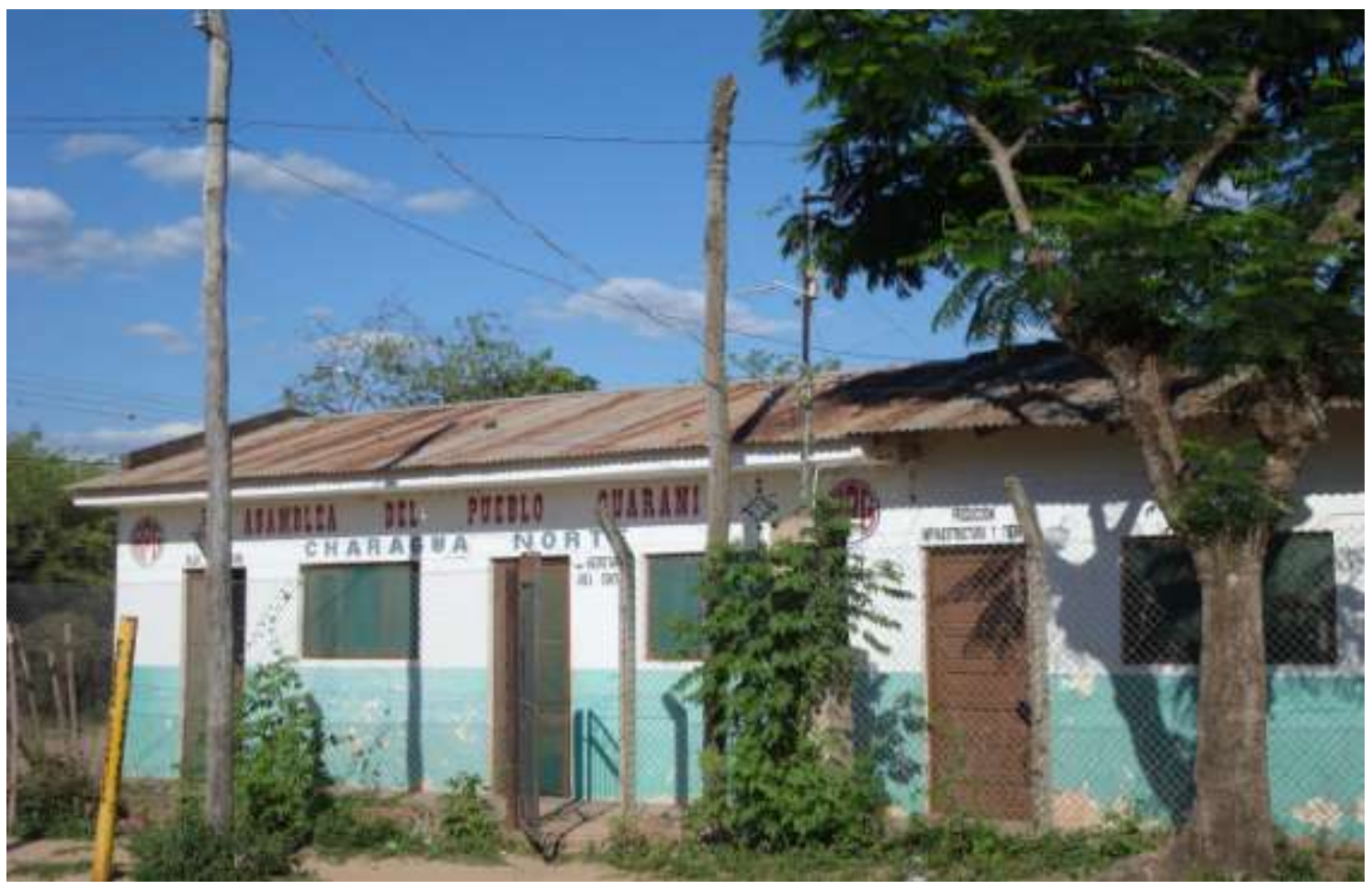

Sede da Capitania de Charagua Norte, em Charagua Pueblo, Charagua.

Autora: Rafaela Nunes Pannain, novembro de 2012.

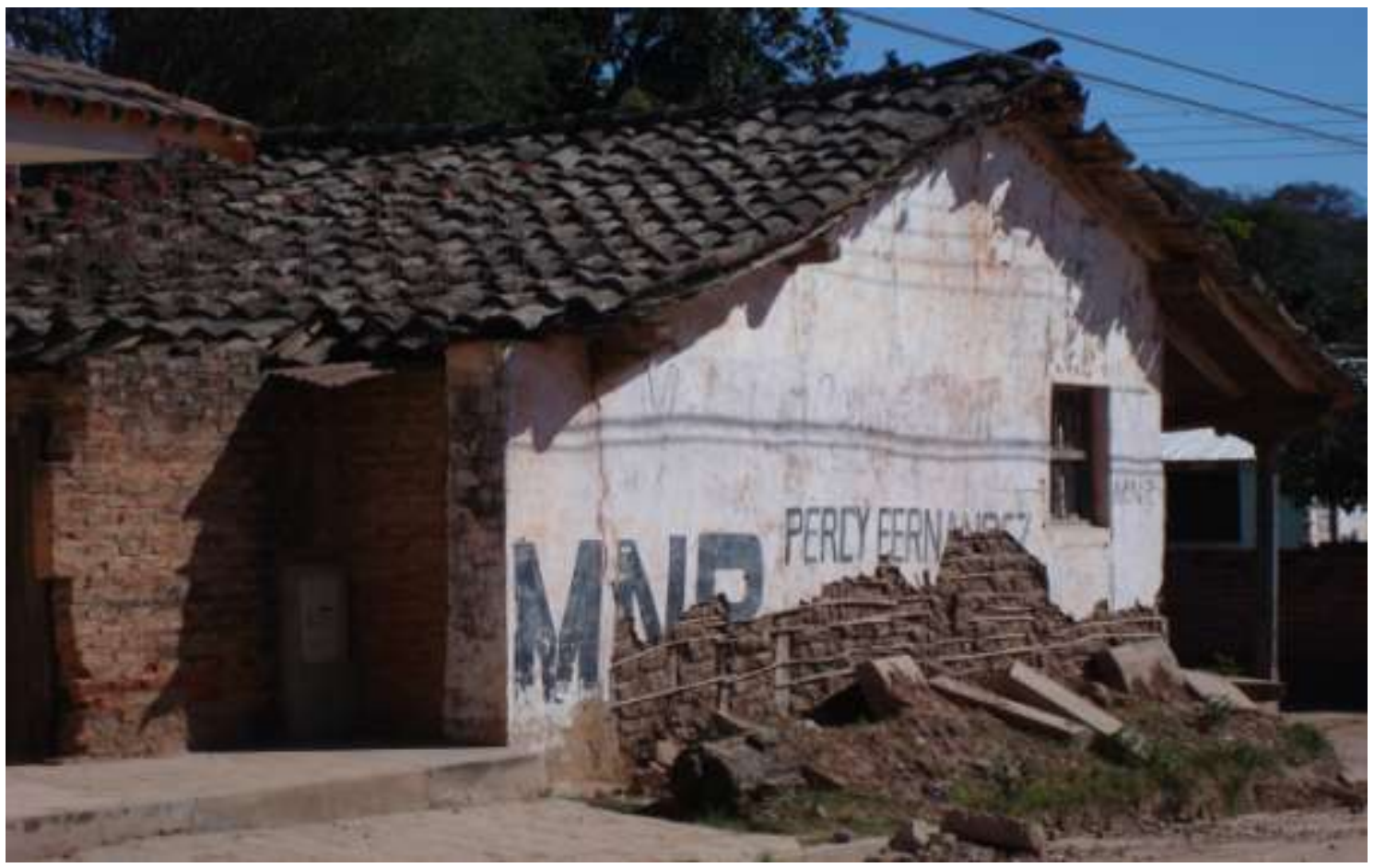

Muro em Charagua Pueblo, com uma antiga campanha do MNR.

Autora: Rafaela Nunes Pannain, setembro de 2012. 